\title{
O ATELIÊ DO ATOR-ENCENADOR: "ENQUADRAMENTO", "INCIDÊNCIA" E "VULNERABILIDADE" NA POÉTICA DA CENA
}

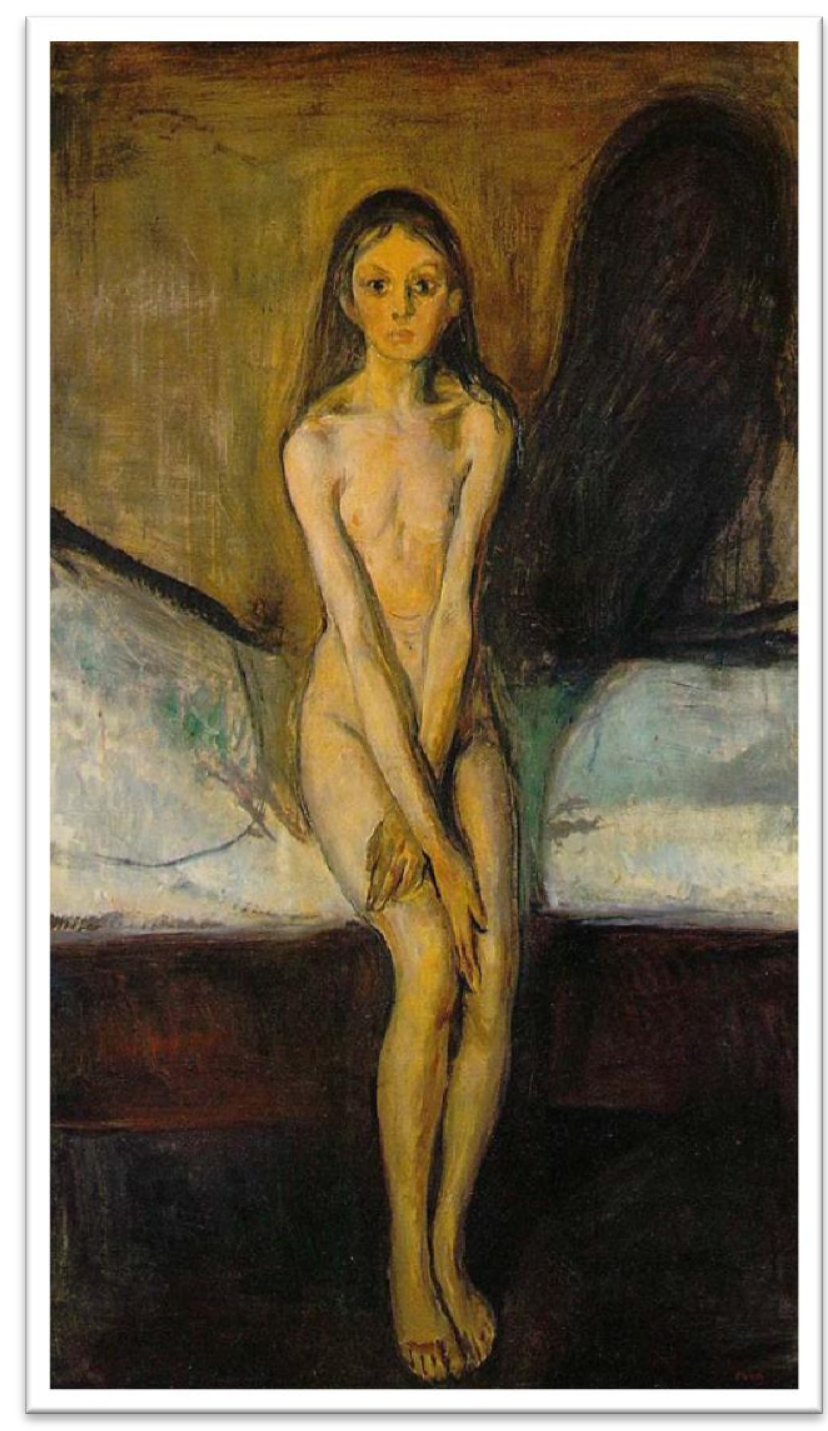

\section{REJANE KASTING ARRUDA}

Tese apresentada ao Programa de Pós-graduação em Artes, Área de Concentração Pedagogia do Teatro, Linha de Pesquisa Formação do Artista Teatral, da Escola de Comunicações e Artes da Universidade de São Paulo, como exigência parcial para obtenção do Título de Doutor em Artes, sob a orientação do Prof. Dr. Armando Sergio da Silva. 
REJANE KASTING ARRUDA

O ATELIÊ DO ATOR-ENCENADOR: “ENQUADRAMENTO", “INCIDÊNCIA" E “VULNERABILIDADE” NA POÉTICA DA CENA.

Tese apresentada ao Programa de Pósgraduação em Artes da Escola de Comunicações e Artes da Universidade de São Paulo para obtenção do título de Doutor em Artes.

Área de Concentração: Pedagogia do Teatro, Linha de Pesquisa Formação do Artista Teatral.

Orientador: Prof. Dr. Armando Sergio da Silva.

São Paulo

2014 
Autorizo a reprodução e divulgação total ou parcial deste trabalho, por qualquer meio convencional ou eletrônico, para fins de estudo e pesquisa, desde que citada a fonte.

Catalogação da Publicação

Serviço de Biblioteca e Documentação

Escola de Comunicações e Artes da Universidade de São Paulo

Dados fornecidos pelo(a) autor(a)

Arruda, Rejane Kasting

O Ateliê do Ator-encenador: "Enquadramento", "Incidência" e "Vulnerabilidade" na Poética da Cena / Rejane Kasting Arruda. - São Paulo: R. K. Arruda, 2014.

238. p.: Il + DVD.

Tese (Doutorado) - Programa de Pós-graduação em Artes Cênicas Escola de Comunicações e Artes / Universidade de São Paulo.

Orientador: Armando Sergio da Silva

Bibliografia

1. Criação Cênica 2. Ator 3. Pedagogia do Teatro 4. Teatro Pósdramático 5. Psicanálise I. Silva, Armando Sergio da. II. Título.

CDD: 21.ed. -792 
Nome: ARRUDA, Rejane Kasting.

Título: O Ateliê do Ator-encenador: "Enquadramento", "Incidência" e "Vulnerabilidade" na Poética da Cena.

Tese apresentada ao Programa de Pós-graduação em Artes da Escola de Comunicações e Artes da Universidade de São Paulo para obtenção do título de Doutor em Artes

Aprovado em:

Banca Examinadora

Prof Dr. Instituição:

Julgamento: Assinatura:

Prof. Dr. Instituição:

Julgamento: Assinatura:

Prof. Dr. Instituição:

Julgamento: Assinatura:

Prof. Dr. Instituição:

Julgamento: Assinatura:

Prof. Dr. Instituição:

Julgamento: Assinatura: 
Dedico este trabalho aos meus alunos... 


\section{Agradecimentos}

A FAPESP pelo valioso apoio, que me possibilitou a intensa dedicação a este trabalho e abriu a possibilidade da participação em eventos de profícua interlocução.

Ao Prof. Dr. Armando Sergio pelos ensinamentos e referencial para toda a vida.

Ao Prof. Dr. Eduardo Tessari Coutinho, pelo olhar atento e pelos debates.

Ao Prof. Dr. Renato Ferracini, pela inestimável colaboração na banca de qualificação deste trabalho.

Ao Prof. Dr. Marcos Bulhões, Prof. Dr. Stephan Baumgartel, Profa. Dra. Josette Feral e Profa. Dra. Béatrice Picon-Vallin pelo aprendizado nas disciplinas oferecidas.

Aos pesquisadores do Centro de Pesquisa em Experimentação Cênica do Ator, cujas palavras me possibilitaram seguir adiante: Adriano Cypriano, Andressa Cabral, Brenda de Oliveira, Carlos Eduardo Witter, Camila Scudeler, Christiane Lopes, Débora Zamariolli, Eduardo de Paula, Evinha Sampaio, Gisele Georgette, Gisela Lourenção, Ivam Cabral, Ipojucan Pereira, João Bourbonnais, José Carlos Machado, Letícia Chiochetta, Livia Figueira, Lúcia de Lellis, Marcelo Braga de Carvalho, Maritza Farías Cerpa, Milena Filócomo, Nathaly Matsuda Franzosi, Ney Piacentini, Paulo Renato Minati Panzeri, Patricia Noronha, Raquel Serradas, Renata Mazzei, Renata Kamla, Renata Vendramin, Rogério de Moura, Ronaldo Ventura, Suzana Alves, Tatiana Melitello, Tatiana Sobrado, Umberto Cerasoli Jr, Vanessa Bruno, Vera Lucia Ribeiro.

A pesquisadora Evinha Sampaio em especial, pela ativa colaboração no "Núcleo 01"

Aos funcionários do Departamento de Artes Cênicas pelo apoio com os afazeres para montagem do espetáculo e demais atividades.

A Elaine Pereira e Miriam Zarate Vilalba pela atenção e disponibilidade.

Aos meus alunos, que me permitem olhar de um ângulo novo para o mesmo objeto.

Aos colegas e professores que, de forma ou de outra, contribuíram para o intercâmbio de ideias.

A Claudia Alves Fabiano, Francisco Peres, Dilson Rufino, Maria Tendlau e René Piazentin, pelo apoio durante os workshops no Circuito TUSP de Teatro. 
Ao TUSP pelos espaços de apresentação e interlocução nas Mostras de Resultados Espetaculares do CEPECA.

Aos professores e alunos da Escola Superior de Teatro e Cinema, pela parceria.

A Camila Jorge, Margarida Agostinho e Sofia Neuparth pela entrevista em Portugal.

A Marcelo Munhoz e aos adoráveis atores da oficina em Curitiba pela troca.

A Academia Internacional de Cinema, Oficina de Atores Nilton Travesso, SP Escola de Teatro e Universidade Vila Velha pelo aprendizado junto à prática pedagógica.

A Ivana Esteves, Sergio Milagre, Vânia Eucinas e Cristiano Burlan, pela compreensão e apoio em momentos importantes desta pesquisa.

A Roberto Propheta Marques, Bia Dias, Christian Dunker, Vladimir Safatle, Glaucia Nagem e demais colegas do Fórum do Campo Lacaniano pela abertura de caminhos.

A Heloísa de Aragão e Ramirez pela travessia.

Ao meu marido, Fabio Diaz Camarneiro, porque sem ele eu não teria conseguido.

Aos meus pais, Sergio Roberto Arruda e Yara Kasting Arruda, pela sólida parceria, confiança e afeto.

Aos meus amigos e parentes, que tantas vezes me ofereceram palavras de estímulo. 
A palavra poética é o que dá voz ao sujeito dividido em sua fragilidade; é a afirmação de uma voz frágil, lugar do feminino por excelência, lugar de um gozo a mais que insiste em efetuar a passagem do indizível à linguagem.

Maria Rita Kehl 


\title{
RESUMO
}

\author{
ARRUDA, R. K. O Ateliê do Ator-encenador: "Enquadramento", "Incidência" e \\ "Vulnerabilidade" na Poética da Cena. 2014. 234 f. Tese (Doutorado) - Escola de \\ Comunicações e Artes, Universidade de São Paulo, São Paulo, 2014.
}

Esta pesquisa propõe uma estrutura de três funções mínimas articuladas (incidência, enquadramento e vulnerabilidade) para a orientação da criação e pedagogia do ator. A sua premissa é o par "anteparo e impressão digital" (extraído do trabalho do Prof. Dr. Armando Sergio da Silva na USP) como estrutural e a sua hipótese é o arranjo: vários anteparos (materiais) a um só tempo implicados na criação de uma impressão digital (inscrição do ator na poética da cena). O método é a criação assistida no "Centro de Pesquisa em Experimentação Cênica do ator", a articulação com a prática pedagógica, teoria teatral e pensamento lacaniano. Procedimentos são formalizados: a.) o jogo de enquadramento, e b.) o pré-jogo - espécie de híbrido entre partiturização e improvisação, fundamentado em uma articulação entre diferentes práxis (a Memorização Através da Escrita de Khan; o treino na imobilidade encontrado em Grotowski; visualização, verbalização e escrita em Kusnet, Stanislavski, Knebel, Adler, Spolin; o princípio da deformação e abstração performativos). São problematizadas duas oposições paradigmáticas (anti-dramático e anti-realista) concluindo-se por uma ética do hibridismo, através do desmonte dos arranjos para a extração de materiais e criação de um estilo de criação. À luz do conceito de "figuras do objeto a" encontrado em Dunker, a criação atoral é situada como algo que põe em questão os limites da forma e implica um excesso que aponta para um lugar de não inscrição na linguagem.

Palavras-chaves: Criação Cênica. Ator. Pedagogia do Teatro. Teatro Pós-dramático. Psicanálise. 


\begin{abstract}
ARRUDA, R. K. The Actor-Meteur en Scéne's Atelier: "Framework", "Incidence" and "Vulnerability" in Scene's Poetics. 2014. 234 f. Tese (Doutorado) - Escola de Comunicações e Artes, Universidade de São Paulo, São Paulo, 2014.

This thesis proposes a structure for actor's pedagogy and creation, articulating three functions (incidence, framework, and vulnerability). Its premises are two structural concepts - "anteparo", and "fingerprint" - after Prof. Dr. Armando Sergio da Silva's work at USP. The hypothesis is the "arrangement": many "anteparos" (materials) at the same time implicated in the creation of a fingerprint (the actor's inscription in scene's poetics). The method is the assisted creation at the "Centro de Pesquisa em Experimentação Cênica do Ator" - CEPECA (Center for Actor's Scenic Experimentations Research), articulated with the pedagogical practice, theater's theory, and the work of Jacques Lacan. Some procedures are formalized: a) the framework's game, and b) the pre-game - a hybrid between the creation of a physical score and improvisation, based on an articulation between different praxis (Khan's "memorization through writing"; Grotowski's “immobility training"; Kusnet's, Stanislavski's, Knebel's, Adler's, and Spolin's visualization, verbalization, and writing; and the principle of performative deformation and abstraction). Two paradigmatic oppositions (anti-dramatic and anti-realistic) are questioned and, in the end, an ethics of hybridism emerges through the dismantlement of arrangements for material's extraction and the creation of a creations' style. In the light of Dunker's concept of "figures of the objet petit $a$ ", actor's creation is understood as something that questions the form's limits and implicates an excess that points out to something non-inscribed in language.
\end{abstract}

Keywords: Scenic Creation. Actor - Theater's Pedagogy. Postdramatisches Theater. Psychoanalyses 


\section{LISTA DE FIGURAS}

Figura 1 - A Pergunta da Pesquisa ............................................................... 03

Figura 2 - A Hipótese da Pesquisa .................................................................... 03

Figura 3 - Intersecção de Procedimentos para a Fundamentação do Ateliê ........ 05

Figura 4 - Estrutura da Impressão Digital .......................................................... 06

Figura 5 - Jogo de Enquadramento ............................................................. 07

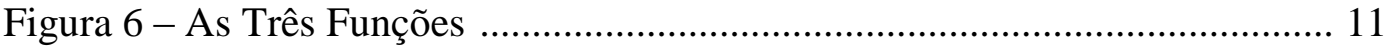

Figura 7 - Pesquisadores do CEPECA-USP ................................................. 12

Figura 8 - Death, Destruction and Detroit (Robert Wilson, 1979) ..................... 17

Figura 9 - Téâtre Libre, fundado por Antoine em 1997 ..................................... 19

Figura 10 - Imagens de Espetáculos de Romeo Castellucci .............................. 20

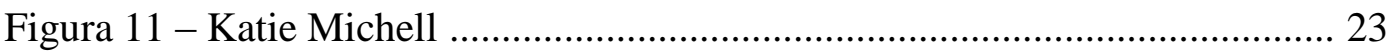

Figura 12 - Os Embaixadores (Hans-Holbein, 1533) - e um detalhe do quadro . 25

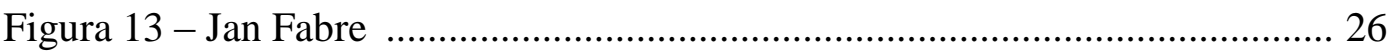

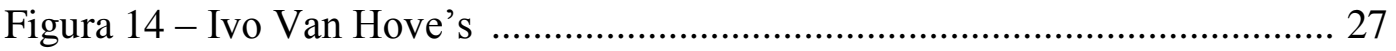

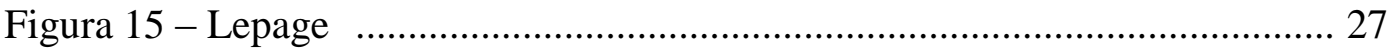

Figura 16 - Anteparos propostos por Meyerhold aos atores .............................. 29

Figura 17 - O Inspetor Geral (Meyehold, 1926) ................................................ 31

Figura 18 - O Corno Magnífico (Meyerhold, 1922) .......................................... 31

Figura 19 - Montagem de "O Rinoceronte” (Ionesco) por Kantor (1961) .......... 33

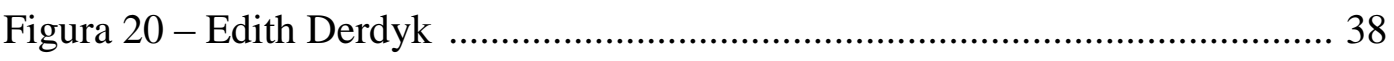

Figura 21 - Anteparo de Bausch: "Ela está presa" ............................................. 38

Figura 22 - Fotogravura (1917) de Paul Strand (1890-1976) na projeção ............ 39

Figura 23 - A menina presa no homem toca "Xote das Meninas

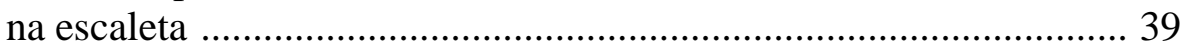

Figura 24 - A boneca evoca a menina sendo repreendida ................................. 40

Figura 25 - Manuscrito que passou pela repetição até a memorização .............. 42

Figura 26 - Manuscrito que passou pela repetição até a memorização ............... 43

Figura 27 - Manuscrito que passou pela repetição até a memorização …............ 44

Figura 28 - Manuscrito que passou pela repetição até a memorização .............. 45

Figura 29 - Fotografias Projetadas em "Casa" ................................................... 46

Figura 30 - "Mamãe, você é uma santa" .......................................................... 47 
Figura 31 - Uma sobre como surrar a esposa ................................................. 47

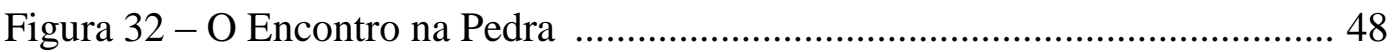

Figura 33 - Foto de cena: "Dancinha infantil quase erótica" .............................. 50

Figura 34 - Foto de Cena: “O Primeiro Beijo" ................................................... 51

Figura 35 - Puberdade (Munch, 1895) ……............................................... 52

Figura 36 - Anteparos Extraídos de Espetáculos de Pina Bausch ...................... 53

Figura 37 - Deslocamentos do Olhar ................................................................ 53

Figura 38 - Walzer (Pina Bausch, 1982) ......................................................... 54

Figura 39 - Foto de Cena: O Beijo no Aquário .................................................... 56

Figura 40 - Projeção na "Cena 4: O Primeiro Beijo" .......................................... 59

Figura 41 - Uma mulher esmurrando um homem ............................................ 60

Figura 42 - Depoimento de mulher sobre primeiro beijo mal sucedido .............. 61

Figura 43 - Nature morte de tasses de café (Roi Vaara, 2005) ............................ 62

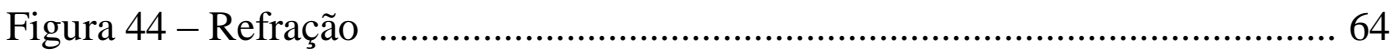

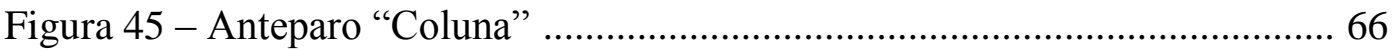

Figura 46 - Sátántangó (Bela Taar, 1994) ....................................................... 67

Figura 47 - Barbara Stanwick em "Pacto de Sangue" (Billy Wilder, 1944) ........ 70

Figura 48 - As atrizes Geraldine Chaplin e Ana Torrent em "Cria Cuervos (Carlos Saura, 1976) ..................................................................... 70

Figura 49 - Atriz Anecy Rocha em “A Lira do Delírio” (Walter Lima Jr, 1969) 71

Figura 50 - Montagem fotográfica (inspirada em Picasso) extraída

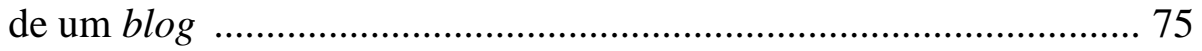

Figura 51 - Mulher Loura com os Seios Nús (Manet, 1878) …........................... 76

Figura 52 - Escultura de Capeaux $(1827-1875)$.................................................. 79

Figura 53 - Standing Woman In Red (Egon Schiele, 1913) ............................. 80

Figura 54 - Story-bord da "Cena 4: O Primeiro Beijo" ....................................... 81

Figura 55 - Story-bord da "Cena 4: O Primeiro Beijo" ...................................... 82

Figura 56 - Entre anteparo e impressão digital: a excitabilidade ....................... 83

Figura 57 - Entre anteparo e impressão digital: memória corporal .................... 85

Figura 58 - Função do enquadramento ............................................................. 86

Figura 59 - Entre anteparo e impressão digital ................................................. 87

Figura 60 - Atualização da Memória Corporal ................................................... 88

Figura 61 - Vulnerabilidade da Memória Corporal ........................................... 88

Figura 62 - Entre Anteparo e Impressão Digital: Contingência ......................... 89 
Figura 63 - Empilhamento ....................................................................... 92

Figura 64 - A Divisão de Foco e o Fora de Foco ................................................. 94

Figura 65 - Enquadramento de um Enquadramento ............................................ 96

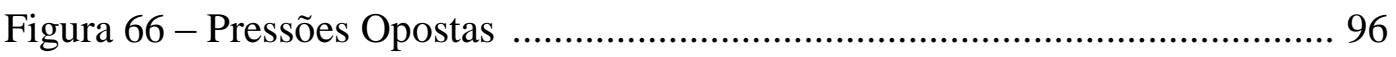

Figura 67 - Obras do pintor contemporâneo Glenn Brown ................................ 97

Figura 68 - Greischwimmer 16 (Wolfgang Tilmans, 2003) .............................. 98

Figura 69 - Cena Enquadrada pela Diegese .................................................... 101

Figura 70 - Escuta em Cena …....................................................................... 101

Figura 71 - Enquadramento Ficcional ............................................................ 102

Figura 72 - Impressão Digital ................................................................. 103

Figura 73 - Plasticidade Corporal e Diegese .................................................. 103

Figura 74 - Jackson Pollock: Number 32, 1950 ............................................. 104

Figura 75 - Abstração de um Movimento e Situação .......................................... 104

Figura 76 - Edward Hopper - Automat, 1927 ................................................. 105

Figura 77 - Abstração de um Movimento e Situação ......................................... 105

Figura 78 - Plasticidade que Estranha .............................................................. 106

Figura 79 - Visualidade do Movimento Absorvida na Situação ....................... 106

Figura 80 - Várias incidências atuando em um mesmo arranjo ......................... 108

Figura 81 - O anteparo "A Menina do Munch” e a impressão digital ............... 108

Figura 82 - As atrizes Geraldine Chaplin e Ana Torrent em "Cria Cuervos" (Carlos Saura, 1976) ..................................................................... 109

Figura 83 - A atriz Barbara Stanwyck em "Pacto de Sangue" (Billy Wilder, 1944) ....................................................................... 110

Figura 84 - Fala externa e material que a antecede .......................................... 111

Figura 85 - Figuras de Pierre-Auguste Renoir (1841-1919) ............................ 112

Figura 86 - Steven Klein, MUBE, 2011 ...................................................... 113

Figura 87 - "Dor! Bem na boca do estômago! Dor, dor, dor! Aiiiiiiii” ............. 114

Figura 88 - Pré-jogo da "Cena 1: A Morte dos Pais" ........................................ 117

Figura 89 - Redução do pré-jogo na "Cena 1: A Morte dos Pais" ..................... 118

Figura 90 - Alunos da ESTC em ateliê cênico .................................................... 119

Figura 91 - A figura nomeada no pré-jogo e a plasticidade corporal constituída em improvisação ........................................................ 120

Figura 92 - Figuras de Schiele utilizadas no ateliê cênico da ESTC ................ 120

Figura 93 - Alunos da ESTC em ateliê cênico ................................................. 121

Figura 94 - Alunos da ESTC na aula do professor Luca Aprea ....................... 121 
Figura 95 - A escuta das impressões digitais

Figura 96 - Fluxo de incidência e enquadramento ............................................ 130

Figura 97 - Formalização das associações que acontecem em cena .................. 141

Figura 98 - Incidência da descrição de corpo na área de vulnerabilidade ......... 143

Figura 99 - Manuscrito com a descrição de corpo ........................................... 146

Figura 100 - Etapa da "psicografia" ........................................................... 147

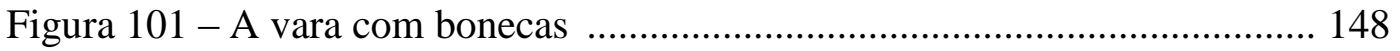

Figura 102 - Stacy Makishi em "How Can I Show You My Love?” ............... 149

Figura 103 - Bonecas cegas ........................................................................ 150

Figura 104 - "Pior que a loucura é a vergonha" e Angélica Lidell .................... 152

Figura 105 - A menina acamada ................................................................. 153

Figura 106 - Um material oculto deixando vago o seu lugar ........................... 154

Figura 107 - O pré-jogo da "Cena 2: Os Cuidados da Avó” ............................ 157

Figura 108 - Pré-jogo sendo memorizado ...................................................... 158

Figura 109 - Pré-jogo borrado ....................................................................... 159

Figura 110 - Pré-jogo na etapa da psicografia ................................................. 160

Figura 111 - Fotografia projetada na cena "Os Cuidados da Avó” .................. 162

Figura 112 - Incidência e enquadramento e vulnerabilidade na MAE .............. 167

Figura 113 - Atravessamentos na área de vulnerabilidade ............................. 172

Figura 114 - A impressão digital entre enquadramento e imagem acústica ...... 177

Figura 115 - Fissuras na fala externa ......................................................... 181

Figura 116 - "Jeune Femme en Buste Dite La Florentine" de Hippolyte Flandrin (1809-1964) .............................................................. 183

Figura 117 - "Hope Dreams” (Charles West Cope, 1869) ............................... 183

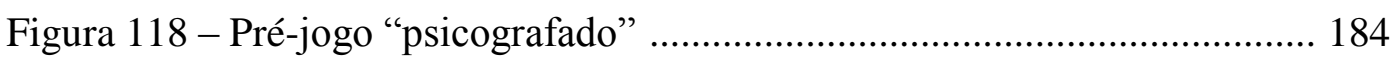

Figura 119 - Exemplo de cadeia associativa ................................................. 187

Figura 120 - As falas internas da "Cena 3: Os Dois Pretendentes sendo

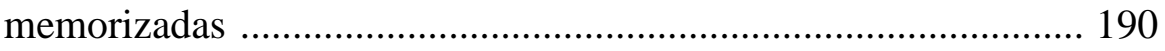

Figura 121 - Momentos da “Cena 3: Os Dois Pretendentes” "............................ 193

Figura 122 - A Família Rodrigues ................................................................ 196

Figura 123 - Alusão à avó ............................................................................... 198

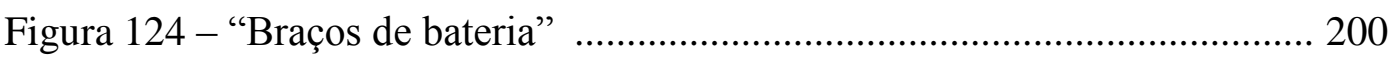

Figura 125 - "Braços de pássaro" ................................................................. 201

Figura 126 - À Margem da Vida, de Tennessee Wiliiams Teatro Ireve Ravache, dezembro de 2013 
Figura 127 - Grupo de Teatro da Universidade de Vila Velha

(agosto a dezembro de 2013)

Figura 128 - Word in progress de Dois Perdidos Numa Noite Suja (agosto a dezembro de 2013) ..................................................... 237

Figura 129 - Interpretação Teatral I - Universidade de Vila Velha (ES) ............ 238

Figura 130 - Workshops Circuito TUSP 2013 239 


\section{LISTA DE TABELAS}

Tabela 1 - Transformações do pré-jogo durante a experimentação cênica ........ 140

Tabela 2 - Falas internas na "Cena 4: Os Dois Pretendentes" .......................... 191

Tabela 3 - Material de incidência e impressão digital ......................................... 202

Tabela 4 - Material de incidência e impressão digital ....................................... 203 


\section{SUMÁRIO}

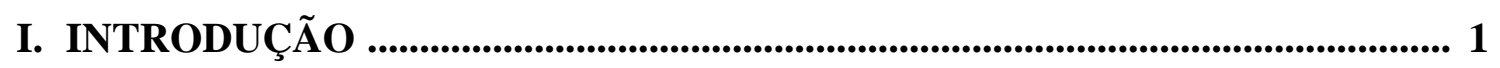

II. UM CAMPO ........................................................................................................... 13

2.1. Relação com a Cultura Cênica ……………………………………………... 13

2.1.1. A Prática no CEPECA …………………………………………... 13

2.1.2. Arranjos Paradigmáticos como Campos de Extração Para um Jogo de Enquadramentos Híbrido ..................................... 15

2.1.3. A cena aponta para um lugar de não inscrição ................................. 24

2.1.4. Fazer ver Outra Coisa .................................................................... 29

2.2. Corte e Encontro de Materiais para um Dizer: A Poluição de "Casa" ....... 37

2.2.1. Encontro Fortuito e Outros Enquadramentos: "A Prisão" ................ 37

2.2.2. Tensões e Olhar: “A Fuga” ............................................................. 46

2.2.3. O Que Estranha? .......................................................................... 50

2.2.4. Associações Impertinentes (ou A Determinação da Associação): "O Primeiro Beijo" ...………………………………... 55

2.2.5. Visualidade da Loucura? "O Plano" ................................................ 62

2.2.6. "Quens" em Jogo .............................................................................. 68

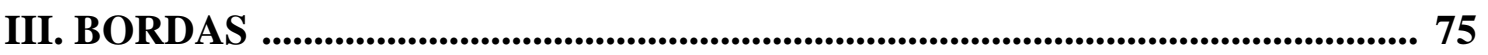

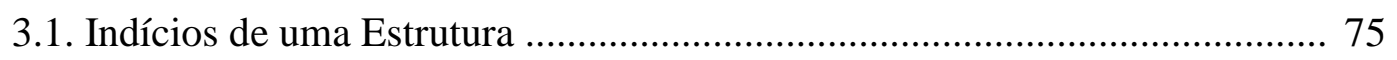

3.1.1. A Instalação da Figura em Cena (Olhar Dentro e Fora).................... 75

3.1.2. Entre Anteparo e Impressão Digital: Uma Reflexão ......................... 82

3.2. O Ateliê de um Pensamento: .......................................................................... 107

3.2.1. Horizontalidade e Verticalidade nos Arranjos: "A Morte dos Pais" 107

3.2.2. A Reverberação de Um Treinamento: Ateliê na ESTC ................... 118

IV. VESTÍGIOS ........................................................................................ 122

4.1. Stanislavski em Perspectiva ………………………………………...... 122

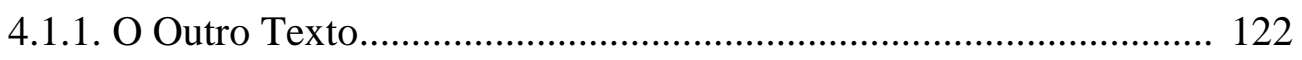

4.1.2. Terra Fértil e Estrela Cadente ......................................................... 135 
4.2. Transformação do Material do Pré-jogo....................................................... 138

4.2.1. "Pina, Nelson, Kieslowski e Eu" ................................................. 138

4.2.2. "Um País de Órfãos" ................................................................ 148

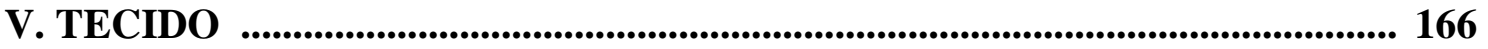

5.1. Um Passo a Passo para a Fundamentação do Procedimento ..................... 166

5.1.1. Duas Cadeias: Spolin no Ateliê ..................................................... 166

5.1.2. Modalidades de Imagens Acústicas: Adler e Knébel .................... 173

5.1.3. Escrita e Redução: Articulação com Kusnet .................................. 178

5.1.4. Escrita e Memória Corporal: Um Treino na Imobilidade ............... 180

5.2. Quantas tessituras serão necessárias? ……….......................................... 188

5.2.1. "Dois Homens e Uma Menina": Um pré-jogo que nasce quase pronto .......................................................................... 188

5.2.2. “A Vingança": Tomada de decisão na reformulação do pré-jogo ... 196

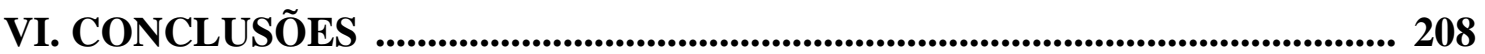

VII. REFERÊNCIAS BIBLIOGRÁFICAS .............................................................. 214

VIII. ANEXO: OUTROS ATELIÊS (REGISTRO FOTOGRÁFICO) ................ 234 


\section{INTRODUÇÃO}

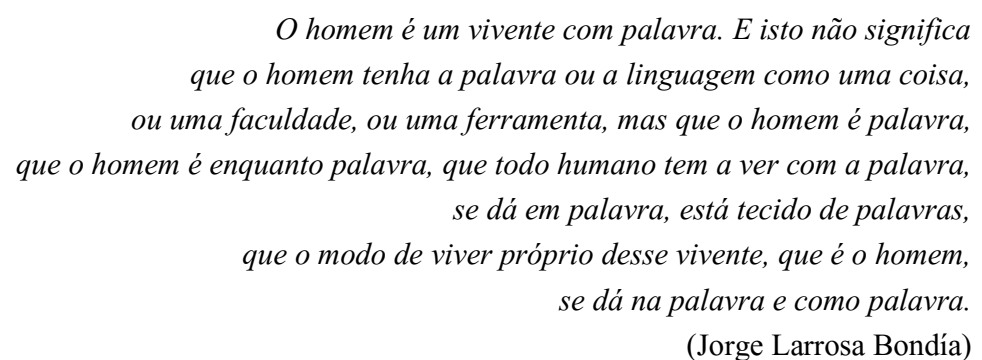

Este trabalho surgiu de um desejo de apaziguar oposições e descobrir uma baliza para a minha prática pedagógica. Dou aulas de Montagem Teatral, Atuação para Cinema e Teatro. Sou atriz e encenadora, apaixonada e estudiosa das poéticas cênica e cinematográfica. Em minha formação, eu me deparei com muitas dicotomias: partitura versus improvisação; Teatro Físico versus um estilo de atuação naturalista (que ora era atribuído a Stanislavski, ora não). Havia também a clássica questão: o impulso era "de dentro para fora" ou "de fora para dentro"? ${ }^{1}$ E a oposição de Grotowski a uma inscrição da cotidianidade em cena, bem como a redução do trabalho de Stanislavski ao "Método de Ações Físicas" (ou ao impulso "de fora para dentro") quando era evidente, em sua literatura, a presença de materiais acústicos e visuais escondidos, que transformavam as ações físicas, implicando outros impulsos. Havia também uma oposição ao "racional" como se não fosse possível uma construção detalhada e planejada sem matar certa dose de intuição que o trabalho necessitava. Esta pesquisa surgiu, simplesmente, do desejo de compreender melhor o meu ofício e de extrair uma estrutura que balizasse as diferenças (tomando-as como diferenças e não dicotomias), para que eu pudesse transmitir, com segurança, a perspectiva de uma práxis ${ }^{2}$ aos meus alunos. O objetivo desta pesquisa é formalizar uma estrutura da prática do ator, extraindo-a a partir de uma experimentação prática vivenciada no $\mathrm{CEPECA}^{3}$, destilando funções para serem transmitidas no exercício pedagógico.

\footnotetext{
${ }^{1}$ Ver GROTOWSKI, Jerzy. Respuesta a Stanislavski. Máscara - Cuaderno Iberamericano de Reflexion sobre Esconologia (Grotowski), México, año 3, n. 11-12. p. 18-26, 1993.

2 Tomo práxis como a articulação entre prática e teoria. O pensar sobre a prática a constitui, ao mesmo tempo em que a prática traz novos desafios à reflexão, formalização e problematização teórica.

3 Centro de Pesquisa em Experimentação Cênica do Ator, coordenado na Universidade de São Paulo pelo Prof. Dr. Armando Sérgio da Silva desde 2007. Reconhecido pelo CNPQ, reúne pesquisadores de doutorado e mestrado, se constituindo, também, como um celeiro de projetos de pesquisa.
} 
$\mathrm{Na}$ práxis formalizada pelo professor $\mathrm{Armando}^{4}$ na USP eu encontrei uma instância que considerei estrutural: o “anteparo”. O Prof. Dr. Armando Sergio da Silva é docente titular da Universidade de São Paulo onde leciona desde 1975. A sua pesquisa de livre-docência, intitulada "Oficina da Essência", foi publicada no primeiro livro do “Centro de Pesquisa em Experimentação Cênica do Ator”: “CEPECA: Uma Oficina de

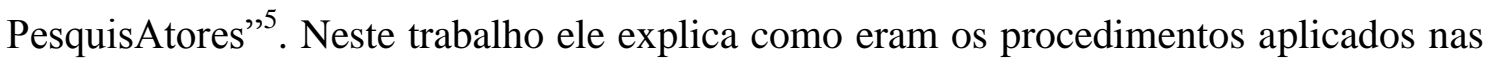
aulas de Interpretação Teatral do curso de Artes Cênicas, bacharelado em Interpretação Teatral, onde estudei de 1995 a 2000.

Anteparos são as palavras, os sons, os objetos e as imagens com os quais o ator joga. Segundo Silva, estes materiais promovem uma triangulação: "Não tem só eu e o meu corpo; tem eu, o meu corpo e o anteparo" (Silva, 2009) ${ }^{6}$. A resultante da criação com estes materiais (a inscrição do ator em uma poética da cena) é chamada "impressão digital". O termo designa a aderência de uma reverberação do material na tessitura corporal. É como se o efeito de reverberação destes materiais despertasse os ecos impregnados na memória, imprimindo um jeito particular de produzir cena no corpo. $\mathrm{O}$ termo "digital" designa algo que é daquele corpo, ator e instante. Assim, ao extrairmos, da cena, uma impressão digital para repeti-la, esta se torna imagem: uma modalidade de anteparo, portanto (há uma mudança de função) - cuja reverberação entra em novo arranjo, com outros anteparos, de maneira que nova impressão digital é criada.

O professor Armando Sergio diz: "Há anteparos por toda a parte” (Silva, 2009) ${ }^{7}$. Quando nós lemos a teoria teatral, testemunhamos o anteparo como estrutural. Apesar de não estar, por este nome, designado, teatrólogos como Stanislavski, Meyerhold, Grotowski, Barba, Spolin, Knebel, testemunham que o ator está sempre a lançar mão de "materiais de estímulo". Apesar das especificidades de cada uma das práxis aqui citadas, há uma evidência do anteparo como uma função que se repete em diferentes processos de criação: esta é uma premissa da pesquisa. O termo anteparo é problematizado. O objeto da pesquisa é o vetor "anteparo - impressão digital" e a nossa pergunta-guia é: “o que acontece entre o anteparo e a impressão digital?”. A hipótese da pesquisa é que existem outras funções, a começar pela "função do arranjo".

\footnotetext{
4 Tomo a liberdade de expor o tratamento que utilizamos no CEPECA: "professor Armando"

5 "PesquisAtor" é um neologismo criado por Silva e também o nome da revista editada pelo CEPECA. Ver: SILVA, A. S. CEPECA, Uma Oficina de PesquisAtores. São Paulo, Sociedade Amigos da Praça, 2010.

${ }^{6}$ Fala pronunciada na Sala 22 do Departamento de Artes Cênicas da Escola de Comunicações e Artes da USP em encontro presencial do CEPECA em 2009.

7 Idem.
} 


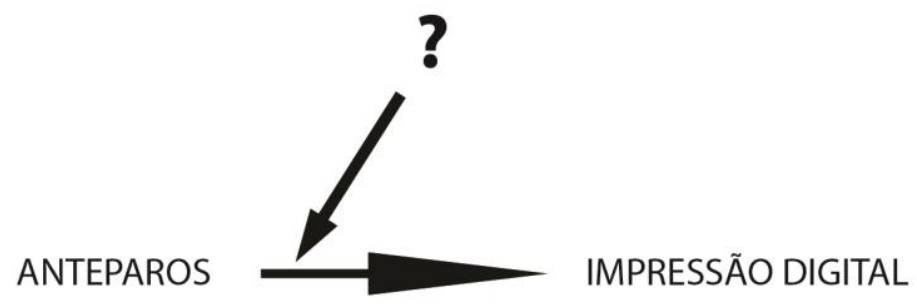

Figura 1: A Pergunta da Pesquisa

Não existe apenas um anteparo, mas vários, atuando, a um só tempo, para a inscrição de uma impressão digital em cena: esta é a hipótese de partida. A impressão digital é constituída por anteparos empilhados, em uma relação de verticalidade (sem intervalo de tempo), atuantes a um só tempo. Esta hipótese é averiguada no processo de criação do espetáculo-solo "Casa: Um Prelúdio ao Desejo" - desenvolvido no CEPECA entre os anos de 2010 e 2013. A hipótese do arranjo implica que, ao escutarmos a cena do corpo, o que se escuta também é anteparo. O anteparo é este material que se pode recortar (e faz incidência, reverbera); pode ser isolado na linguagem - e arranjado com outros. De maneira que, apesar da ação física (tradicionalmente posta como o elemento estrutural) estar implicada no jogo do ator, na medida em que pode ser isolada, ela é uma das notas que ressoa em um acorde complexo.

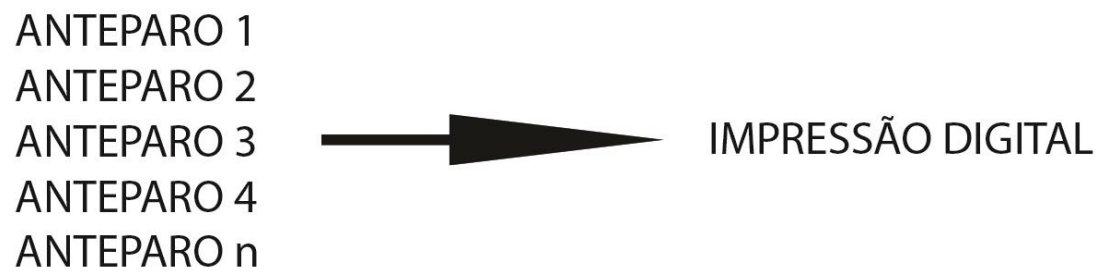

Figura 2: A Hipótese da Pesquisa

Muitas vezes começamos uma pesquisa e não sabemos quais surpresas vão advir no caminho. Estando constantemente em contato com outros pesquisadores e recebendo interlocução assídua no CEPECA (as pesquisas são presenciais), me deparei com evidências que não estavam contempladas anteriormente. Por exemplo, havia, como hipótese de partida, a função do arranjo com modalidades diferentes de anteparos: palavras, imagem, som, objetos e incluí o movimento - já que pode ser recortado com a 
linguagem e composto com outros. Mas percebi, durante a pesquisa (ao me deparar com diferentes interlocuções), que é preciso considerar, também, as diferentes modalidades de arranjos situadas em práxis teatrais diferentes (e que muitas vezes se opõem).

Como atores, nós nos inscrevemos em uma cultura cênica. Cada pensamento ou linha de pesquisa implica arranjos específicos de anteparos-palavra; de anteparosimagem; de anteparos-movimento. Cada escola (Barba, Decroux, Spolin, Stanislavski, Grotowski, Lecoq, etc) implica instruções de jogo específicas, significantes específicos no arranjo, responsáveis pela inscrição dos corpos em uma poética, em uma cultura, em um discurso específico. Cada pensamento atoral reverbera palavras diferentes. Estas palavras ecoam, incidem sobre o ator - são anteparos (silenciosos) em um arranjo. Não é possível, na escolha de materiais para a averiguação da hipótese do arranjo, esquecerse disto.

Quais procedimentos, quais arranjos seguir? Parto dos meus vinte e cinco anos de prática; dos procedimentos que experimento e percebo que me ajudam na inscrição em cena. Dedico-me a uma espécie de circuito: a experimentação em cenas diante dos pesquisadores do CEPECA; a experimentação como atriz em outros trabalhos, fora do CEPECA; a experimentação com meus alunos, em diferentes práticas criativas; o diálogo com a teoria teatral (que me entusiasma ao perceber semelhanças); o retorno à prática no CEPECA, criação e escrita deste texto. Partindo das minhas experiências com Spolin, Barba, Silva, Stanislavski, Khan, deglutidas a meu modo, destilando o que mais funciona para mim e os meus alunos, intersecciono procedimentos diferentes, pensando a prática em função de um estilo de criação e pedagogia próprio.

Assim, por um lado, esta pesquisa se fundamenta em algo autoral, singular: um jeito particular de criar e ensinar. Por outro, eu me esforço por fazer valer algo "para todos" - que funcione como uma teoria, a ser apropriada e usada, citada e desdobrada por outros em nosso campo. Uma criação de algo singular, que implica um jeito próprio de misturar procedimentos, serve para extrair uma estrutura de funções articuladas a ser transmitida a outros. Conto com a criação (processo de criação solo) como um método. Criado com a assistência dos demais pesquisadores (especialmente Evinha Sampaio que colaborou ativamente nos ensaios), o espetáculo "Casa: Um Prelúdio ao Desejo" é um documento da pesquisa. Formalizo um procedimento de etapas bem definidas, repetido em diferentes ateliês (com alunos e trabalhos como atriz fora do CEPECA) e que surge da articulação abaixo. 


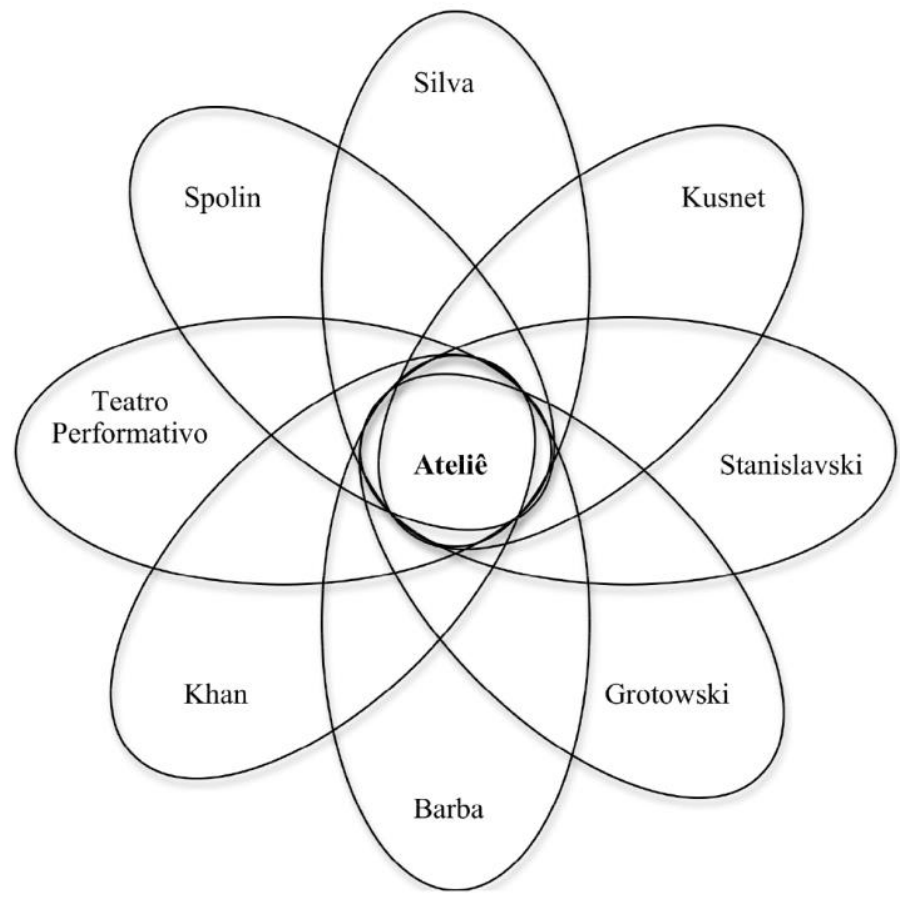

Figura 3: Intersecção de Procedimentos para a Fundamentação do Ateliê

Não se pretende dar conta da validação, defesa ou totalidade de cada uma das pedagogias interseccionadas, mas da parte que diz respeito à intersecção implicada no ateliê como um procedimento de criação. A figura acima revela, no ponto de intersecção entre elas, o campo de investigação que chamo "Ateliê do Ator-encenador" ao postular o ator como "um encenador de incidências no corpo". O procedimento fundado com esta intersecção é uma improvisação, diante de outros, com o que chamo de "pré-jogo": um texto de próprio punho com os materiais nomeados e descritos. O que formalizo na pesquisa é: enquanto alguns materiais incidem, promovendo certo caos, outros ordenam tempo e espaço. As primeiras duas funções extraídas do ateliê são: a "incidência" (a reverberação do anteparo na tessitura da memória corporal) e o "enquadramento" (a organização dos efeitos de reverberação em um tempo e espaço).

Assim, entro na questão da impressão digital. Tal como o enquadramento de uma câmera de cinema, o desenho do corpo aparece como as bordas, como os limites de uma superfície (assim como os limites espaciais ou temporais, oferecidos por um objeto, uma música ou figurino). A questão é que a incidência de anteparos ocultos tende a romper estes limites; dilatando a impressão digital que conta com o enquadramento plástico-corporal do desenho ou movimento. Um testemunho da pesquisa é a oposição entre a incidência de materiais ocultos (que desorganizam) e o enquadramento (que, 
com a sua incidência, organiza) - uma oposição que implica a impressão digital como "viva" ("orgânica", tal como, em nosso campo, se diz). De maneira que incidência e enquadramento, apesar de serem funções diferentes, não são dicotômicos. Eles são estruturais e podem opor-se (a resultante é a impressão digital), mas não são divergentes. Eles coexistem na estrutura.

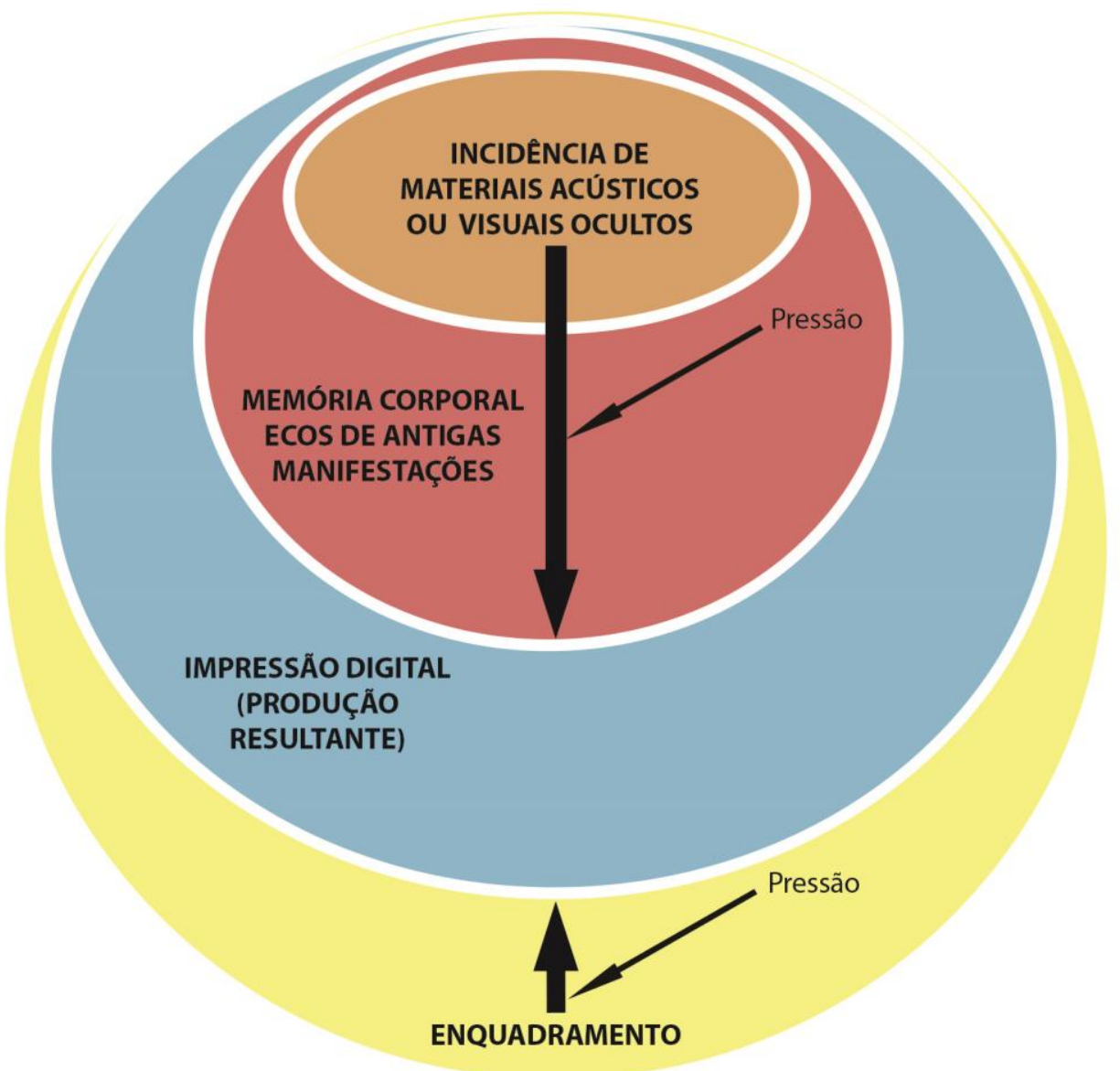

Figura 4: Estrutura da Impressão Digital

O espetáculo-solo “Casa: Um Prelúdio ao Desejo" é desmontado. Exponho os arranjos e o passo a passo da criação, problematizando as operações e revelando o que chamo "jogo de enquadramento". Uma fala, por exemplo, exige um intervalo de tempo para a sua enunciação; a visualidade de uma situação ficcional se configura como um enquadramento, pois situa a impressão digital em um espaço-tempo (outro, ficcional). Estas diferentes modalidades de enquadramento se combinam ou se opõem. Por estar só em cena, criei o que chamei "régua sonora": uma voz sonorizada. Esta voz implica a visualidade de uma relação (entre atriz e voz). A relação situa as impressões digitais. As 
distâncias entre as palavras sonorizadas marcam intervalos de tempo e criam ritmos de alternância. Assim, se constrói limites, bordas, para os efeitos de reverberação (de um arranjo de anteparos) que podem se desdobrar até a próxima fala sonorizada. Este é um exemplo de jogo de enquadramento.

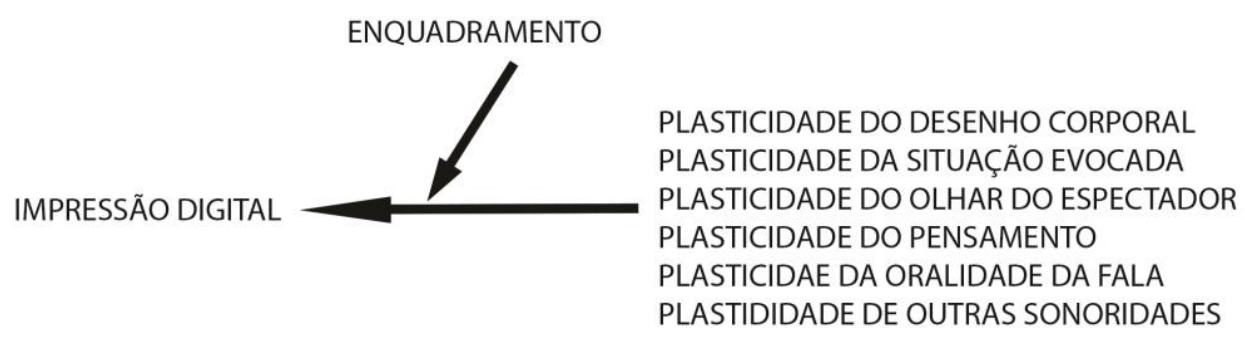

Figura 5: Jogo de Enquadramento

A visualidade de uma ação também é uma modalidade de enquadramento para uma impressão digital, pois a situa (situa a impressão digital) em um espaço-tempo que não é o da superfície da cena, mas se dá por associação, na imaginação do espectador. A visualidade da fábula é evocada com a sucessão de desenhos do corpo ou a sucessão das palavras. Em “Casa”, fragmentos de um passado são narrados. Há uma voz narrativa, extraída do romance "Minha Vida", escrito por Nelson Rodrigues com o pseudônimo de Suzana Flag nos Anos 40. A cena evoca a visualidade da relação da narradora com os fatos que conta. A ideia é que o espectador testemunhe o olhar da narradora como uma modalidade de enquadramento e o seu próprio olhar, quando as suas associações situam as impressões digitais na visualidade do seu mundo. Reconhecer que o olhar enquadra com a visualidade associada no "instante-já” não implica atribuir um significado estável à impressão digital. Percebe-se uma montagem, por parte do espectador, uma diferença de lugares estrutural que Grotowski postula: "O ciclo das associações pessoais do ator pode ser uma coisa e a lógica, que aparece na percepção do espectador, outra." (GROTOWSKI, 2012, p. 233).

$\mathrm{O}$ ator maneja materiais ocultos. Estes materiais surgem de livre-associações (um mosaico de associações fragmentadas, extraídas de outros contextos, inclusive a apropriação do próprio contexto de jogo). O que importa é encontrar materiais que possam oferecer incidência para "preencher" o enquadramento: pressioná-lo, dilatá-lo. 
Se o ator joga com a interpretação, esta se torna um "campo de extração" de anteparos. Esta noção é utilizada nesta pesquisa: um livro, uma pessoa, uma imagem, um filme, a memória, uma fantasia e também a interpretação, são campos de extração de materiais. Estruturalmente, não se sabe como estes vão ressoar na tessitura corporal (e acordar os seus ecos), produzindo a impressão digital junto a outras reverberações que perdemos de vista - o não saber implica a criação por mais anteparos que se tenha.

Durante a criação no CEPECA, de 2010 a 2013, apresentei cenas para receber a interlocução do grupo que se reúne todas as quintas-feiras pela manhã na Sala 22 do Departamento de Artes Cênicas da Universidade de São Paulo e me deparei com a evidência de duas modalidades de arranjos paradigmaticamente diferentes (a diferença é paradigmática). Trabalhando no cinema (especificamente com certa demanda do cinema contemporâneo emergente por atuações naturalistas), utilizo uma cotidianidade; o que, nas aulas de atuação, chamo de "corpo sujo". Esta atuação depende de uma "divisão de foco" ${ }^{\prime 8}$ com atividades cotidianas, para que a visualidade da situação de representação seja diluída. O foco de atenção é também dividido entre a fala que se diz e a que não se diz ("interna") - ou uma "música interna" - de maneira que a ilusão de espontaneidade seja produzida. Porque a fala externa vem para substituir a fala interna e, nesta operação de troca, é inscrita como um impulso. Assim, produz-se um efeito de inscrição do ator "na realidade" do filme.

O arranjo que suporta a atuação naturalista é tomado, nesta pesquisa, como uma modalidade paradigmaticamente diferente da "atuação estranhada", constituída, durante o século XX, como poética cênica autônoma em relação à diegese ${ }^{9}-\mathrm{e}$ onde a abstração ou deformação fogem à inscrição do cotidiano: são "estranhas" ao comum do corpo, ao humano do corpo (a poética do desenho ou movimento é autônoma em relação à poética do drama). Os arranjos de "Casa" implicam uma tentativa de uma resolução híbrida entre estes arranjos paradigmáticos - e também entre outra oposição: partitura física versus práticas de improviso.

Mesmo implicando enquadramento, em uma prática de improviso, os materiais não estão fixados de forma detalhada (como acontece com a partitura física) ${ }^{10}$. Busco

\footnotetext{
8 Esta instância será debatida durante o trabalho.

9 "Diegese: 1 . o tempo e o espaço de uma narrativa ou trama; 1.1. conjunto de aspectos relativos ao tempo e o espaço de uma narrativa qualquer; etimologia: Gr. Diegesis "narrativa” (Dicionário Houass).

10 "Segundo Patrice Pavis, o primeiro diretor a utilizar tal noção de partitura foi Stanislavski, que a utiliza em seus estudos sobre a linha geral das ações físicas: a ação do ator destinada à construção da personagem e da linha dramatúrgica deveria ser fixada e repetida numa partitura, conseguindo-se com tal procedimento a verossimilhança da ação física em termos de organicidade e seqüência lógica. Já Meyerhold não utiliza propriamente o termo 'partitura', mas fala em seus escritos de 'desenho do
} 
um hibridismo também entre estas duas práticas. Proponho a partitura não física, mas de anteparos (detalhada com as palavras), como se fosse uma rubrica que o ator memoriza com a repetição da sua escrita no papel. Assim, durante o improviso, conto com uma ordenação de impulsos. Porque a repetição da palavra escrita fixa as reverberações sequenciadas na tessitura corporal. Utilizo a nomeação e descrição de figuras extraídas das artes plásticas (ou do teatro performativo) para trabalhar a plasticidade corporal alternando-as com materiais como: instruções de jogo, associações, memórias, fantasias, pensamentos (e as falas externas, se as tenho). É este procedimento que utilizo na minha prática criativa e pedagógica com variações conforme o ateliê.

Em cena, nos deparamos com uma área (fissura aberta) entre a reverberação no corpo (a atualização dos impulsos daquela partitura de anteparos) e o espaço-tempo. E também com uma área (fissura aberta) entre o espaço-tempo cênico e a incidência do anteparo oculto (interno) que está ocupando o foco de atenção naquele momento. A impressão digital surge como um preenchimento destas áreas abertas. Entre o espaçotempo aberto e a incidência do foco descubro a atualização dos ecos (na tessitura corporal) das reverberações daquela partitura de anteparos anotados na folha de papel (reverberações das repetições do ato da escrita). De maneira a improvisar. Para preencher as fissuras abertas é preciso mais que aqueles impulsos, algo que se descobre na hora. Entre o enquadramento espaço-temporal e a incidência do anteparo em foco, através de ecos na memória corporal, é criada a impressão digital. Há uma "área de vulnerabilidade" na tessitura corporal, atualizando ecos que perdemos de vista (junto às reverberações da cadeia memorizada).

A este texto, de próprio punho, escrito (onde são introduzidas as falas externas e internas, nomeações das figuras extraídas das artes plásticas, instruções de jogo), chamo "pré-jogo". O ato de documentar, com o verbo escrito, anteparos, e memorizalos com a repetição da escrita, constitui-se como uma modalidade de "Treino na Imobilidade"11. Trata-se de um desdobramento da "Memorização Através da Escrita",

movimento' ou de 'escritura dos movimentos plásticos”' (PETRY, 2006, p. 2). Ver PAVIS, T. “Antologia portatile sulla partitura”, in: MARINIS, M. (org.) Drammaturgia dell'attore, Porreta Terme: I Quaderni del Battello Ebbro, 1996.

${ }_{11}$ "Sem que os outros percebam, se pode treinar as ações físicas e fazer as composições das ações físicas permanecendo no nível dos impulsos. Isso quer dizer que as ações ainda não aparecem, mas estão no corpo, porque são im/pulso. (...) vossas ações físicas serão assimiladas ainda mais pela vossa natureza se treinarem os impulsos, não as ações. Podemos dizer que a ação física quase nasceu, mas ainda é bloqueada, e assim, no nosso dizer, estamos "impostando" uma reação justa, assim como se imposta a voz.” (RICHARDS, 1993, p. 94 apud BONFITTO, 2007, p. 74) 
transmitida por François Khan ${ }^{12}$, a partir da intersecção com Silva, Spolin, Stanislavski, Knébel, Barba, Kusnet e certos princípios do Teatro Performativo. A descrição de anteparos plásticos (extraídos das Artes Plásticas ou Teatro Performativo) objetiva uma poética "estranhada" da forma, desenho, movimento. Esta descrição vai para o pré-jogo. A escrita repetitiva do pré-jogo, treino (na imobilidade, mas que envolve esforço e faz vibrar o corpo inteiro), impregna a memória corporal das suas reverberações (que são atualizadas em cena em função de um jogo). Há uma margem de transformação destes materiais no improviso, de maneira a acomodá-los à "fala interna", à relação ou ao pensamento (e resultar em uma forma híbrida).

"Fala interna" é um termo que encontrei em Kusnet e adotei. Kusnet diz: "Os pensamentos resultantes da improvisação só se transformam em 'Monólogo Interior' quando o ator consegue conscientizá-los, isto é, transformá-los em 'Falas Internas", (KUSNET, 1992, p. 72). Trata-se de uma escuta no silêncio; de anotar (escrever) e escutar (sem expor) palavras (imagens acústicas, anteparos-palavra) reverberando no corpo. Trata-se de criar palavras (não ditas, não expostas) para anteparo. Kusnet diz: “ $O$ ator deve analisar as imagens, traduzi-las em palavras, transformando-as dessa maneira em 'Falas Internas' próprias do 'Monólogo Interior'” (idem). A hipótese do arranjo implica que materiais que não vemos em cena (que estão ocultos, que apenas o ator os ouve e vê) são também anteparos. E que estes materiais podem ser encadeados, formando uma subpartiura que vai dilatar o desenho corporal, borrar, transformar. Neste caso, um apoio é Kusnet, por sistematizar a visualização, a utilização da fala interna e, também, a escrita como procedimento. O que ele chama de "raciocínio" consideramos uma modalidade de utilização da linguagem que, de acordo com a fundamentação teórica escolhida, tem implicado o corpo. Utilizamos Lacan justamente por tratar-se de um pensamento que fundamenta o verbo intimamente ligado ao corpo e situando um gozo (no corpo), além de uma maneira de manejo deste gozo.

Ao desenvolver a pesquisa junto ao CEPECA, me deparo com a evidência de escolhas para além da estrutura extraída (e que implicam uma estética ou um estilo). Chego à conclusão de que não é possível criar sem me posicionar diante de oposições que consolidaram o campo teatral. A pesquisa prática e acadêmica, desenvolvida no CEPECA, abre a perspectiva de descobrir algo próprio, como uma solução híbrida que, no entanto, não é neutra, pois implica certa perspectiva estética e posicionamento do

${ }^{12}$ Hoje diretor do grupo chamado "Teatro da Câmera", participou do trabalho de Grotowski na época do "Teatro das Fontes". 
olhar da atriz-encenadora. Assim, descubro que um arranjo de anteparos (hipótese de partida) não conta, apenas, com escolhas de imagem, música, objeto, som e movimento, mas com escolhas de falas ocultas que (a semelhança de instruções de jogo) articulam significantes destilados na cultura teatral. Além da estrutura com funções articuladas, que nomeei "incidência, enquadramento e vulnerabilidade", a opção pelo pré-jogo em improviso surge como uma possibilidade pedagógica e de criação.

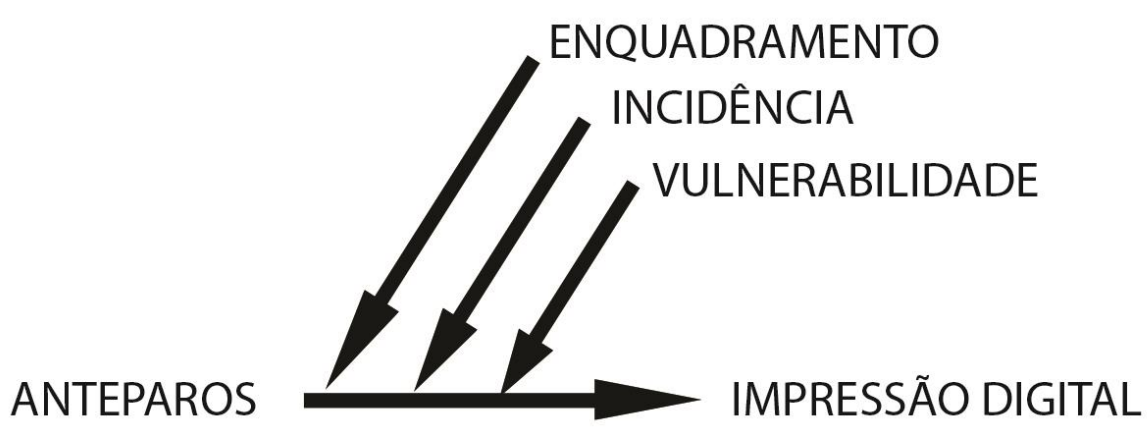

Figura 6: As Três Funções

A vulnerabilidade, terceira função destilada na pesquisa, se apresenta como um território de atravessamentos na tessitura corporal, memória que desperta; uma tessitura vulnerável à incidência dos anteparos que mexem esta área (que, por sua vez, precisa ser enquadrada). É preciso manejar as três funções para criar. Se o enquadramento não se configura, a poética cênica também não. No entanto, pode haver uma deformação constante do enquadramento através das atualizações na área de vulnerabilidade quando anteparos ocultos fazem incidência. Quanto ao enquadramento, construo um jogo. Os arranjos de "Casa" são criados com o superobjetivo "mostração". Assim, o discurso teórico que sustenta a pesquisa serve como uma espécie de campo de extração de anteparos também.

O relato é realizado em primeira pessoa e revezo o tempo passado e o presente, bem como exposição da prática e teoria, a fim de dinamizar a transmissão. Nove cenas são desmontadas. Utilizo desenhos que me ajudam a figurar as operações. Fundamento e reflito sobre este objeto escorregadio: "o que acontece entre anteparo e impressão digital". Afinal, como falar a respeito do estar dentro da cena? Como evidenciar o que acontece em um átimo de segundo de atualização instantânea e reverberações na memória corporal? Como demonstrar operações que não se encontram expostas na 
horizontalidade da cena? Que são verticais? Como inscrever no universal da teoria uma operação singular?

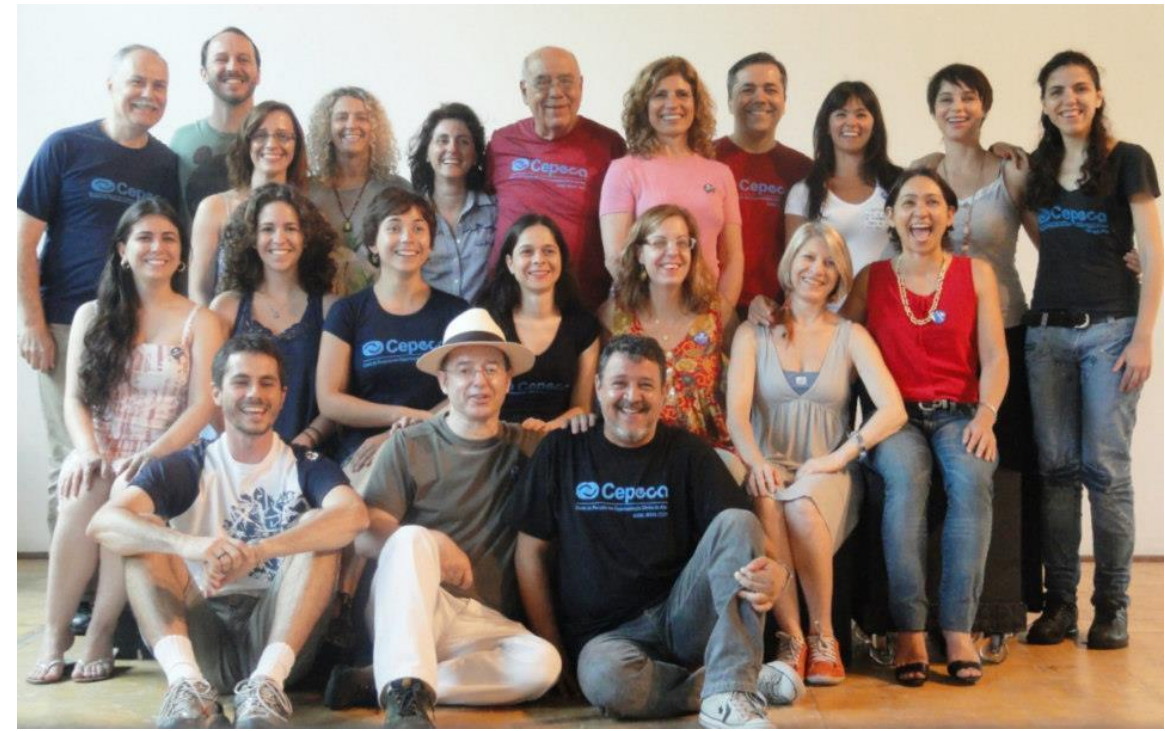

Figura 7:

Pesquisadores

do CEPECA-USP

(Foto de arquivo, $6 / 12 / 2012)$ 


\section{Um Campo}

Sem a loucura, que é o homem?

Mais que a besta sadia, cadáver adiado que procria?

(Fernando Pessoa)

\subsection{Relação com a Cultura Cênica}

\subsubsection{A Prática no CEPECA}

Pesquiso no CEPECA desde a sua fundação em 2007. Observando a prática dos pesquisadores percebo que, ao descrever e defender os procedimentos, verbalmente, para o outro, nosso corpo se modifica e encena a incidência daquele discurso sobre ele. Encontro esta operação em Stanislavski. Há incidência de uma fala, que implica relação com o outro: "O ritmo tem que ser sentido no olhar, nos pequenos movimentos. Querem um ritmo enlouquecedor, pois vejam” (TOPORKOV, 1990, p. 309). Toporkov comenta: "Era um espetáculo delicioso, o olhávamos fascinados, enquanto ele, imperturbável, seguia com seus exercícios" (idem, p. 310) ${ }^{1}$.

$\mathrm{O}$ ator-pesquisador inclui, no seu arranjo de anteparos, um discurso sobre a prática (e sua hipótese) para construir um corpo. A incidência da fala em nome próprio está presente, junto aquela certeza que "pega em algum ponto do corpo” (Soler, 2010). Percebo que, no CEPECA, a defesa acalorada se instala, no jogo do ator, como anteparo (material). O trabalho do ator-pesquisador testemunha a dialética entre pulsão e saber. A clássica divisão "razão e emoção" se dilui. Brecht foi contra a oposição entre razão e emoção: "É o teatro ortodoxo que peca por dividir razão e emoção" (BRECHT, 1978, p. 83) ${ }^{2}$. Kusnet cunhou a expressão "ideia que ferve" (Kusnet, 1992). Como poderia, nos termos do ateliê, traduzir certa apatia do ator em cena? Diferente da oposição à racionalidade, não se trataria do contrário? Um corpo adormecido devido à falta de pensamento, excitação, estímulo, desejo? Se não há enlaçamento em anteparos, não há

1 "El ritmo tiene que sentirse en la mirada, en los pequeños movimientos. Quieren un ritmo enloquecedor? Pues, véanlo". (TOPORKOV, 1990, p. 309) "Era un espectáculo delicioso, lo mirávamos embelesados, mientras que él, imperturbable, seguía con su ejercicio" (idem: 310). Tradução nossa. Ver: TOPORKOV, V. O. Las acciones Físicas como Metodologia. In: (Org.) JIMENEZ, S. El Evangelio de Stanislavski Segun sus Apostoles. México: Gaceta, 1990, p. 309-310.

2 Em "Breve enumeração dos equívocos mais frequentes, surrados e aborrecidos a respeito do teatro épico" (no "Pequeno Organon Para o Teatro") Brecht diz: "O teatro épico não é contra as emoções; ele procura examiná-las, não se limitando a estimulá-las” (BRECHT, 1978, p. 83). 
encenação de incidências (não há incidência para ser encenada). Se a emoção não está em oposição à razão e se a razão ferve, como diz Kusnet, não é o excesso de pensamento, mas a falta dele o responsável pela apatia. Na pesquisa acadêmica prática, o corpo se transforma com a instalação de anteparos extraídos da práxis de Checkóv, Laban, Grotowski, Stanislavski, Decroux, Meyerhold, na medida em que, com elas, pomos algo nosso. Quando o ator expõe os procedimentos para demonstrar o processo no CEPECA, dialoga com uma cultura que não é a plástica ou a musical, apenas, mas a cênica. $\mathrm{O}$ ator extrai anteparos internos a um discurso que organiza a poética corporal e se configura como instrução de jogo, fazendo o corpo produzir. Neste momento, o que transforma o corpo é a proposição extraída de uma poética do outro na qual o ator se filia: o golpe do Tai-ken-dô, a mímica do Decroux, a proposição do BMC (as pesquisas são diferentes e a riqueza está nesta diversidade), a ação psicológica do Chékhov. Por trás da inscrição corporal está uma construção verbal que funciona como "subpartitura" (Barba, 2005).

\begin{abstract}
O efeito de verdade buscado por Stanislavski, a teatralidade buscada por Meyerhold, o efeito de estranhamento buscado por Brecht indicam objetivos opostos em termos de resultado, mas não divergentes no processo. Estes diferentes objetivos pressupõe, por trás da coerência da ação externa da partitura, uma coerente organização da subpartitura, de um "forro do pensamento" que o ator controla. Ela (a subpartitura) é constituída por imagens circunstanciadas ou por regras técnicas, por experiências ou perguntas feitas a si mesmo, ou por ritmos, modelos dinâmicos ou por situações vividas ou hipotéticas (BARBA, 1993, p. 171 apud BONFITTO, 2007, p. 80).
\end{abstract}

Estes materiais, extraídos da teoria pelo pesquisador, estão no mesmo lugar que a voz da direção quando incide no corpo, a música, um objeto com o qual se improvisa: o ator entra em relação com falas que o apoiam e transformam a tessitura corporal. Ao responder ao outro, ao defender o procedimento, ela vem carregada de paixão: “Quando o ator explica o que quer da ação, o seu corpo muda", testemunha o Prof. Dr. Eduardo Coutinho $^{3}$ no CEPECA. A proposição testemunha que o verbo que o ator usa é um dos anteparos que constrói a impressão digital; de maneira que a poética corporal não deixa de ser um efeito de linguagem. A relação do ator com esta na qual ele se inscreve e defende envolve pulsão, o afeto e certa modalidade de enquadramento. Partimos deste reconhecimento: colocar-se em nome próprio para a invasão das incidências de uma fala que implica um olhar sobre a criação e um diálogo com o campo teatral.

3 O Prof. Dr. Eduardo Tessari Coutinho é vice-coordenador do CEPECA, orientador de parte das pesquisas e participa das interlocuções. 


\subsubsection{Arranjos Paradigmáticos como Campos de Extração}

para um Jogo de Enquadramentos Híbrido

Tudo entreguei ao assombro Mesmo o mais familiar.

(Bertolt Brecht)

A maioria dos arranjos que manejo na prática pedagógica advém do trabalho com o texto dramático. Atualmente as escolas técnicas de formação de atores em São Paulo têm um lugar para o performativo, mas trata-se da demanda de preparar o aluno, também, para um campo onde o dramático está situado como um mercado de trabalho. Um dos problemas com os quais me deparo é transmitir, ao ator em formação, que a cena é uma poética e não a resultante de uma representação do discurso sobre uma personagem. Trabalhar a atuação como performativa mesmo no trabalho com o texto dramático, evidenciando, para o espectador, um eixo extra-ficcional da tessitura da obra, é um esforço que tenho feito. Uma das estratégias é mostrar-lhes arranjos que fujam da representação dramática para servirem de campo de extração de anteparos. Percebo uma necessidade de eleger, na história e no campo teatral, arranjos; e desmembrá-los, para o diálogo não apenas com as artes plásticas (de onde extraímos anteparos-imagem), mas também com uma cultura cênica e suas diferentes resoluções.

O século XX foi pautado por sucessivos movimentos de oposição ao realismo. Os termos "naturalismo" e "realismo" se confundem e são problemáticos, mas nem por isto deixam de ser utilizados na crítica, na imitação e citação. Na teledramaturgia, por exemplo, a atuação, citada como realista, é, na maior parte do tempo, melodramática. A atuação na teledramaturgia é diferente, por exemplo, da atuação naturalista demandada pelo cinema contemporâneo emergente. Não temos como especificar as diferenças aqui, mas basta dizer que se trata de uma estilização a partir de demandas de uma codificação específica. O que estou tomando como paradigma de uma atuação realista não está na teledramaturgia ou no teatro convencional (que deixou de ser problematizado), mas no cinema.

A atuação realista é de difícil inscrição em cena. Este dado é histórico. Mesmo Antoine, ao fazer as suas primeiras experiências, levando adiante os projetos de Zola, recebeu uma série de críticas, pois o que se via em cena, muitas vezes, eram recursos do melodrama e romantismo inscritos de uma forma insistente. O primeiro reconhecimento 
adveio com a montagem de "Os Açogueiros" de Fernand Icres (em 1888). Segundo Marvin Carlson o termo foi introduzido, no campo teatral, por Lewes na Inglaterra nos meados do século XIX (1847), acompanhando as noções de representação da vida, empatia, naturalidade, verossimilhança: o ator deve representar o personagem de forma que "ele nos afete como real" (CARLSON, 1997, p. 223). Mas é o termo naturalismo que se encontra especialmente ligado aos projetos de Zola e Antoine, articulado a uma visão cientificista da arte: o teatro deve ser um documento do mundo a ser investigado. De qualquer maneira, foi ao projeto de inscrição de uma visualidade da realidade em cena que o século XX se insurgiu contra, com projetos onde se afirma a plasticidade cênica como autônoma. A oposição à literatura dramática segue paralela, pois, neste caso, a palavra evocaria uma visualidade da ficção para a cena representar.

Roubine situa a dinâmica de um pensamento dos "zeladores do texto" que, de certa forma, fomenta reações antidramáticas, pois, se por um lado, "se empenham em renovar a arte da representação" por outro, "proclamam a eminente superioridade do texto sobre todos os outros componentes do teatro" (ROUBINE, 2003, p. 142). Coupeau, Dullin, Baty, Ptöeff, Jouvet, Barrault, Vilar "pertencem a gerações diferentes e fazem escolhas estéticas diversas, afirmando, com sua prática, um vínculo fundamental e criativo entre representação e texto de teatro" (idem, p. 145). São contra o Teatro de Boulevard (de rua) e o Melodrama (que se afirmara na transmissão oral e cujo apelo para o visual, segundo eles, macula o texto como obra prima). O que eles defendem: o encenador traz à cena a verdade escondida do texto. Antes de Barthes defender a multiplicidade do sentido e o Teatro do Absurdo postular o esvaziamento da palavra, Copeau e Jouvet dedicavam-se a novos dispositivos cênicos e de atuação (com a pesquisa sobre a Commedia Dell'Arte, Nô e Kabuki, de maneira que serviram de base para a Mímica Moderna). Mas ainda assim afirmavam: “É apenas o ensino do texto que guia, é o texto que conduz uma representação" (JOUVET, 1952 apud ROUBINE, 2003, p. 144) $)^{4}$; "Para abordar uma obra-prima, para responder à sua solicitação, para ouvi-la, existe apenas uma atitude: a submissão" (idem); "Para toda realização existe um caminho da verdade pelo qual o autor passou que é nossa missão reencontrar para ai passarmos, por nossa vez" (COUPEAU, 1984 apud ROUBINE, 2003, p. 146) $)^{5}$. Diante disto, Roubine se pergunta: "O que pode então ser uma direção (mise-en-

4 JOUVET, Louis, Témoignages sur le théâtre. Paris, Flammarion, 1952.

5 COPEAU, Jacques “A interpretações das obras dramáticas do passado” In: COPEAU, Jacques. Registrei, II, III, IV. Paris, Gallimard, 1974-84. 
scène)? Visar o segredo de uma obra não é correr atrás de uma miragem que foge incessantemente?" (ROUBINE, 2003, p. 148). Nos Anos 60 Barthes "proclama a inanidade da busca de uma verdade supostamente embutida no coração do texto e a inesgotável polissemia das obras-primas” (idem, p. 147). Aparentemente a polissemia surge como uma saída: "Há, na obra-prima, algo de inesgotável. Ela não recepta uma verdade oculta, mas mil, e mais: Uma verdadeira peça contém todas as ideias, todas as teorias, todas as concepções imagináveis" (JOUVET, 1952 apud ROUBINE, 2003, p. $148)^{6}$. Mas, ainda é o texto dramático que "fala". Vilar assume os espaços abertos (com apenas alguns signos essenciais) para "deixar o texto falar". A encenação permanece em tensão com o texto dramático. Roubine defende a ideia de "dupla soberania": do texto e do encenador em tensão. Segundo ele, são os movimentos nos Anos 60, com o "Living Theatre" e "Bred und Puppett Theatre", que vão reestabelecer o paradigma do evento cênico. É o choque do ritual, da cerimônia cênica e a influência da performance, que vão estabelecer outro conceito de teatro. Bob Wilson em 1971:

\begin{abstract}
(...) trabalha com predileção sobre o gesto. Inscreve-o em uma temporalidade tão diferente - a da duração vivenciada, e do tempo estilizado do teatro - que ela adquire com isso uma estranheza radical. O Olhar do Surdo encadeia imagens hieráticas e secretas durante sete horas! Quanto à palavra, como já preconizava Artaud (...). Gritos ou salmodias, ela fornece uma música primordial que se soma à utilização de composições instrumentais cujas potencialidades repetitivas e alucinatórias desempenham um papel essencial. Enfim, o universo wilsoniano é povoado de figuras exageradamente aumentadas, manequins ou atores (ROUBINE, 2003, p. 168)
\end{abstract}

Vê-se então outro arranjo - outro paradigma de se fazer teatro. A imagem e o corpo como poéticas autônomas. Hoje vemos o campo teatral dedicar-se as discussões suscitadas pela obra de Hanz-Ties Lehamnn: "O Teatro Pós-dramático" - que organizou a análise de um movimento teatral múltiplo formado a partir dos Anos 60, de diversas tendências, mas tendo em comum, apesar das diferenças, a extrapolação do enquadramento dramático. Os procedimentos para o ator acompanharam estes dois movimentos: contrários ao realismo por um lado e ao dramático por outro.

${ }^{6}$ JOUVET, Louis. Témoignages sur le théâtre. Paris, Flammarion, 1952. 


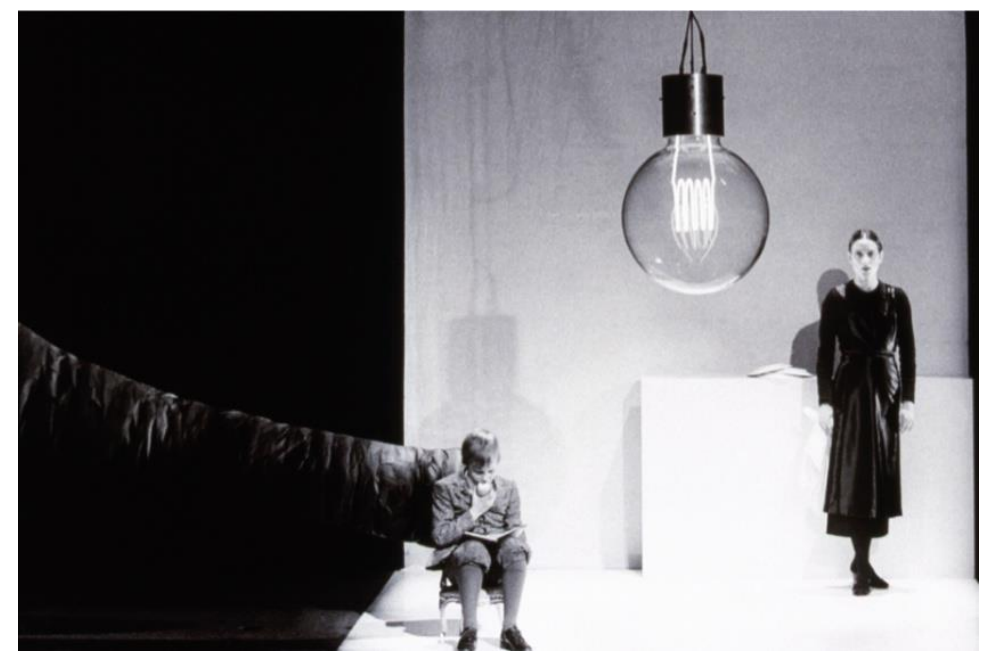

Figura 8: Death, Destruction and Detroit (Robert Wilson, 1979)

Mas já na primeira metade do século XX o paradigma da poética cênica como autônoma se estabeleceu, de forma múltipla, com projetos diversos. Vemos Meyerhold recuperar a visualidade do teatro de feira, dedicar-se ao grotesco e a abstração dos gestos; Brecht procurar o gesto estilizado, cuja primazia da forma implica a evocação da crítica (já que o ator inscreve a visualidade do seu pensamento e não "se esconde atrás" do enquadramento da ficção); Piscator intensificar as projeções, de maneira a sobrepôlas umas por cima das outras; a Bauhaus investir no ator como linha, grafismo; Craig teorizar o ator-marionete, projeto retomado em novos termos por Kantor, em um teatro onde a marionete é o modelo que o ator deve regar de vida; Grotowski se opôr à visualidade do gesto cotidiano e postular a ação física como um "ato total" (junto à visualidade do sacrifício e transe); Artaud dedicar-se às pesquisas com a sonoridade e o ritual para constituir o teatro como peste (termo que advém de Santo Agostinho, cuja "crueldade" é capturar o espectador, contagiá-lo de modo que perceba apenas quando é tarde demais $)^{7}$ - há visualidade da relação com o espectador: "somos capazes de fazê-lo gritar" (ARTAUD, 2008, p. 31). E o Living Theater dedicar-se a rituais coletivos para constituir um teatro ativista, de cunho libertador no mundo escravizado pela indústria armamentista e uma série de ditaduras; vemos Bob Wilson imperar com o "Teatro de Imagens", sem a palavra do texto dramático ou quando sim, sobreposta pela força da plasticidade das imagens; vemos Barba constituir uma teoria do ator que lança mão da estilização nos teatros orientais como a principal referência; e as fronteiras entre ator e bailarino serem borradas com a Thanz-theater de Pina Bausch; o dado biográfico

7 "O teatro tem efeito retardado; você já está mudado e não tinha percebido. É tarde demais para recuar" (WILLEMART, 1996, p. 206). 
utilizado como material de trabalho moldado em montagem e constituído como poética da cena; a proliferação do vídeo e materiais plásticos; a poética dos objetos e do som; a retomada da cultura popular como material cênico e a visualidade do oriente em trabalhos como os de Ariane Mnouchkine e Peter Brook.

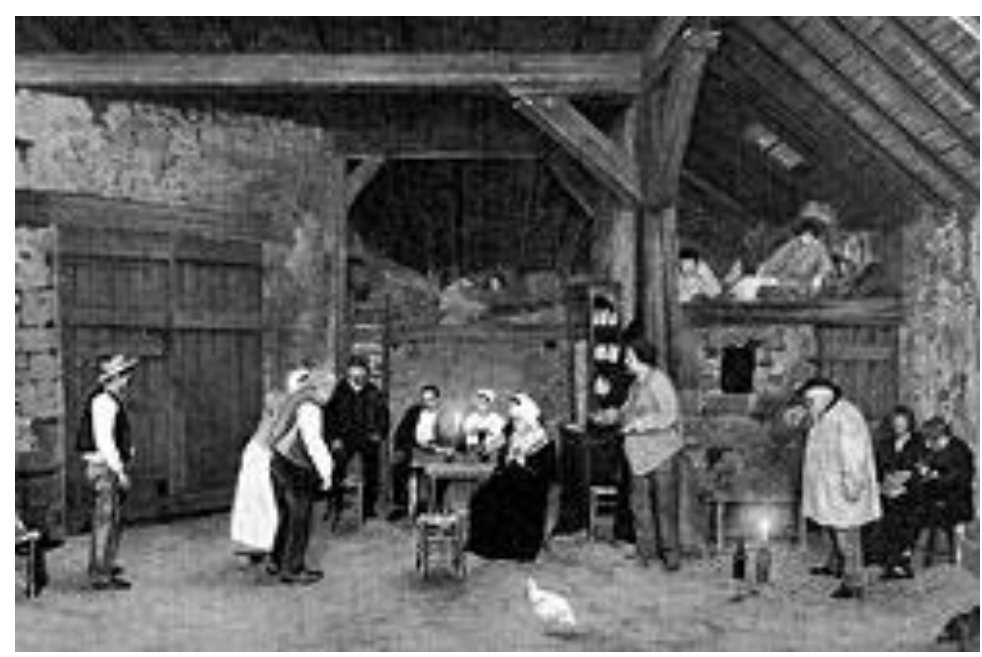

Figura 9:

Téâtre Libre, fundado por Antoine em 1887

De maneira que, sucessivos projetos anti-realistas marcaram, cada qual a seu modo, a consolidação de uma poética cênica autônoma em relação à literatura dramática ou a mimese da realidade proposta pelo projeto naturalista de Antoine. Até chegarmos ao que Lehamnn designou como pós-dramático percebe-se uma recusa da visualidade de um universo diegético (ficcional) fechado. Este mundo, onde indivíduos encontramse implicados em relações intersubjetivas (evocadas pelo texto) a serem representadas é posto em cheque. Em relação aos textos considerados pós-dramáticos, o conflito e a progressão oferecida pelo dramático é uma espécie de referência a ser quebrada, seja pelos elementos épicos ou por materiais que, entre outros, Jean-Pierre Sarrazac e JeanPierre Ryngaert se dedicam a consolidar. São figuras como: coralidades e partilhas de vozes, onde não se sabe mais quem está falando; a paródia, a citação e diversas misturas que Sarrazac designa "monstros": "Não se trata de, em nome de qualquer modelo mecanicista, desumanizar o drama, mas sim de produzir obras contra naturam $e$ preferir à imitação rígida da bela natureza a livre variedade dos monstros" (SARRAZAC, 2002: p. 56 apud BRAGA, 2007, p. 02) - uma micelânia de tendências reelaboradas de modo singular por cada autor, de maneira que a contemporaneidade se configura como uma escrita múltipla.

A oposição que Lehmann faz ao dramático é explícita - e está articulada a uma tradição crítica alemã que passou por Walter Benjamin defendendo a narrativa e Peter 
Szondi operacionalizando um estudo da dramaturgia a partir da oposição entre épico e dramático. A posição de Sarrazac é diferente da posição de Szondi que, com a oposição do épico ao dramático, demonstra a falência do segundo; e de Lehmann, que defende a escritura cênica sem o texto que a anteceda. Sarrazac defende um texto híbrido - assim como Pavis postula uma cena híbrida, entre a performance e a encenação (com o que nomeou performise). O texto dramático tem estado presente como campo de extração de materiais, servindo ao encenador na medida em que misturado com outros campos. Tal como Krzysztof Warlikowski ${ }^{8}$ quando mistura fragmentos de Otelo, O Mercador de Veneza e Rei Lear; ou Vitez quando "amarra" versos de Yannis Ritsos com pedaços de Electra (Sófocles); e Romeu Castellucci ${ }^{9}$ que, ao montar Julio César, coloca um ator obeso como Cícero (e a visualidade estranhada dos corpos entra em relação com a visualidade evocada no texto, gerando uma teatralidade específica daquele espetáculo).
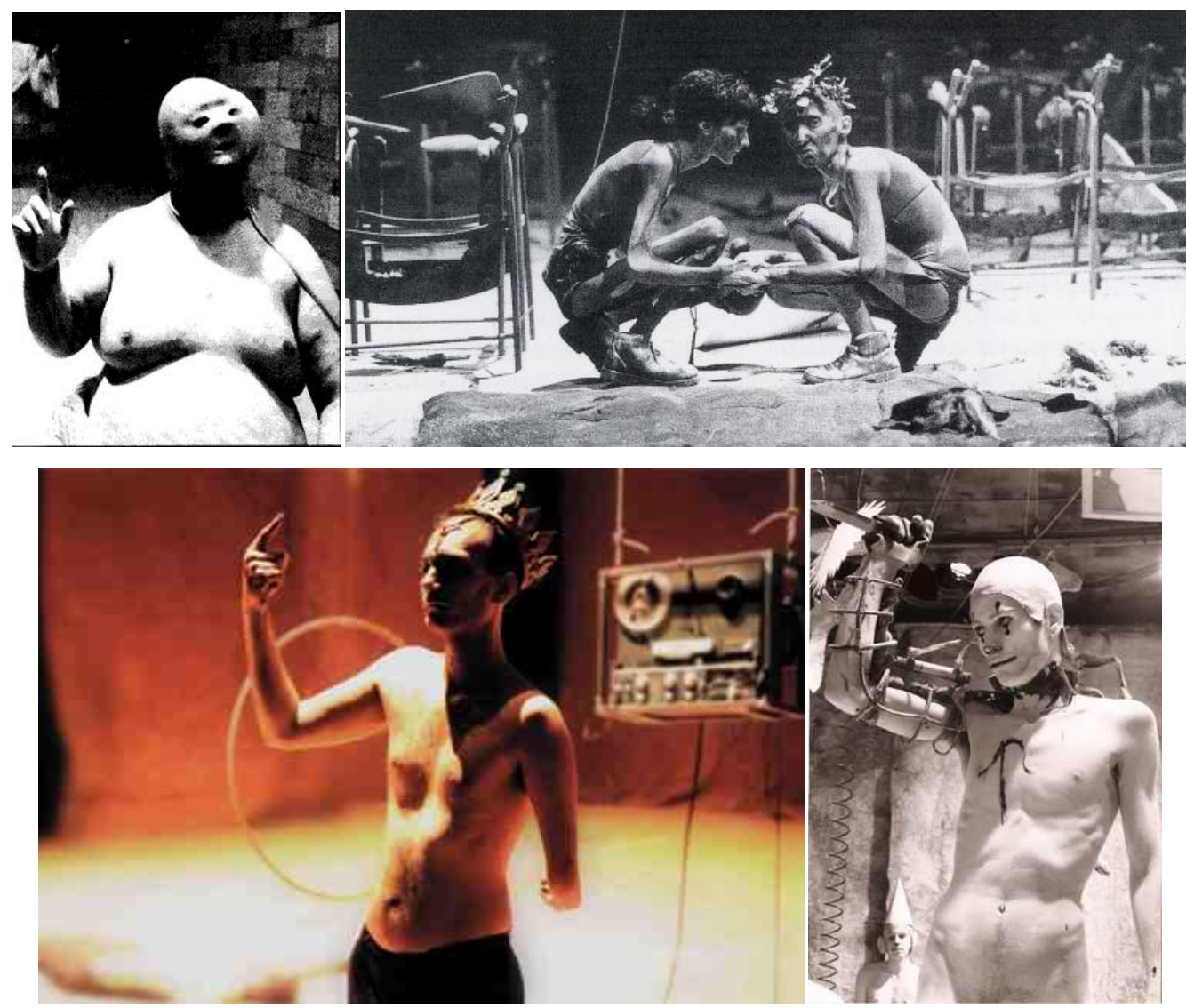

Figura 10: Imagens de Espetáculos de Romeo Castellucci

\footnotetext{
${ }^{8}$ Diretor da companhia polaca "Wroclawski Teatr Wxpólezesny".

9 Diretor da "Societas Raffaello Sanzio" (Itália).
} 
No bojo da crítica ao teatro dramático está a ideia de que o ator "representa" enquanto, no performativo, ele "age"; ele atua (em nome próprio). Algo semelhante ao que, no teatro naturalista (ou cujo projeto de atuação é naturalista) se demanda por: "o ator não representa, ele vive"? Segundo Roubine, aquilo que Antoine buscava na "fatia de vida", acaba por causar o estranhamento de uma alucinação. O "como se" fosse real, segundo Roubine "oferece ao espectador uma nova vertigem":

O exemplo paradigmático dessa vontade de deslocar as fronteiras que separa a realidade do campo da representação, de torná-los no fundo difusas, será $O s$ açogueiros, de Fernand Icres (1888). Menciona-se bastante essa realização de Antoine, não sem alguma condescendência a respeito da pretensa "ingenuidade" do diretor. Imaginem. Ele havia decidido suprimir os acessórios tradicionais de cartolina mole e substituí-los por verdadeiras carcaças de carneiro, por "verdadeiros" pedaços de carne expostos no balcão do açougue que é o ambiente da peça! Mas Antoine era certamente menos "ingênuo" do que se dizia. Sabia que a confusão do fictício e do real e que o mimetismo integral no teatro definem uma utopia. Que o próprio da utopia é nunca se realizar. O problema é que, ao misturar as fronteiras, ao injetar, na imagem cênica, o real em estado bruto, ele expandia o campo referenciado da teatralidade e oferecia ao espectador algo como uma nova vertigem, a perturbação excitante da incerteza... O século XX, através das buscas mais antagônicas, e frequentemente as mais afastadas do naturalismo, não será capaz de se lembrar que o real também pode se tornar teatro. E que tem uma "presença", como se diz, de extraordinária intensidade! O interesse da direção naturalista é que no fundo ela não designou claramente seu objetivo: acreditando que estava simplesmente desenvolvendo a arte do mimetismo, melhorando as técnicas da representação. O teatro não é mais apenas o lugar de uma ilusão mais ou menos "perfeita". Torna-se um espaço de alucinação. $\mathrm{O}$ espectador acredita que está deixando o real na porta do teatro. O real o alcança no cerne do espetáculo e o lança na deliciosa confusão de uma percepção sem referências estáveis (ROUBINE, 2003, p. 115)

"O século XX, através das buscas mais antagônicas, e frequentemente as mais afastadas do naturalismo" (ROUBINE, 2003, p. 115): deparamo-nos o tempo todo com os testemunhos das oposições; estas, que me ajudam a escolher materiais e montar arranjos de maneira a dialogar com uma cultura da cena e os seus principais impasses. Assim, uma plasticidade corporal do dia-a-dia ou "da realidade" pode se situar como uma das modalidades possíveis de enquadramento (em jogo), pois é tecida de imagem. Tal como a visualidade da progressão e desenlace dramáticos, da crítica ou da distância temporal (presente no teatro épico). Assim como o quadro de cinema ou da pintura; tal como um espelho (que reflete a imagem), a "realidade" é uma visualidade a partir da qual se pode extrair um fragmento ou outro. Não se configura como inteiriça, mas implica limites. Para que alguns dos seus elementos possam ser postos em cena, ela pode ser quebrada, assim como o contexto diegético (que situa limites também). São visualidades, muitas 
vezes ofuscadas pela mise-en-scene - e é a partir deste fato que se estabelece uma tensão (que percebemos no ateliê) entre a plasticidade da fábula e da cena; entre o texto (que evoca uma visualidade) e a encenação (que implica a sua própria visualidade).

É possível utilizar materiais implicados na atuação naturalista, por exemplo, a divisão de foco entre uma atividade cotidiana e a visualidade da relação com o outro; entre fala interna e externa; entre a diluição do gesto e a plasticidade do pensamento. $\mathrm{O}$ jogo de enquadramento pode contar com uma inscrição em um espaço-tempo ficcional quando o ator é situado ali como vivente. A ilusão da vida individual se inscreve; ela aparece: é vista. Nos projetos anti-realistas, ao contrário, a inscrição do corpo conta com diferentes modalidades de exacerbação de uma plasticidade cênica: uma poética da abstração da imagem ou da forma corporal; o jogo de evocação da crítica, da paródia; a visualidade da rua, festa, feira, pop; da deformação, do ritual, do sacrifício; a visualidade da morte (como postula Kantor) ou do boneco, aproximando a cena teatral da pintura e dança moderna (ou as desproporções inscritas com as projeções de vídeos). Quando pensamos no teatro pós-dramático como o lugar ao qual chegamos (pensando no campo onde se inserem encenadores como Jan Fabre, Frank Castorf, Christoph Schilngensief, Rene Pollesch, Robert Lepage, Roger Vontobel, Romeu Castellucci, John Romão, Anatolli Vassiliev, Robert Wilson, Pina Bausch, Peter Brook, Ariane Mouchkine, Richard Foreman, Peter Stein e tantos outros), podemos dizer que, ao utilizar a cotidianidade do corpo (valorizada na poética realista) se rompe com o contexto ficcional. Ou, ainda, que se redimenciona o corpo, ampliando a sua imagem com projeções; trazendo à cena uma poética dos bastidores, como acontece em Katie Michell. A encenadora britânica criou um estilo particular de encenar, misturando vídeos e cena:

\footnotetext{
Uma mistura de cena viva e vídeos simultaneamente projetados daquela própria ação. Ter a câmera no palco para que você possa ver como as imagens são construídas (...). Em "Trem Noturno" são gabinetes no palco, existem câmeras em todo lugar, você pode ver alguém colocando o projetor. E lá na tela é bem realista. Isso é o que eu chamaria o lado brechtiano do pósdramático no teatro. Como Brecht quis expor a mecânica da construção. ${ }^{10}$
}

${ }^{10}$ Fala de Marvin Carlson no Colóquio Internacional "Pensar a Cena Contemporânea" em Florianópolis, UDESC, junho de 2013 (não publicado). 


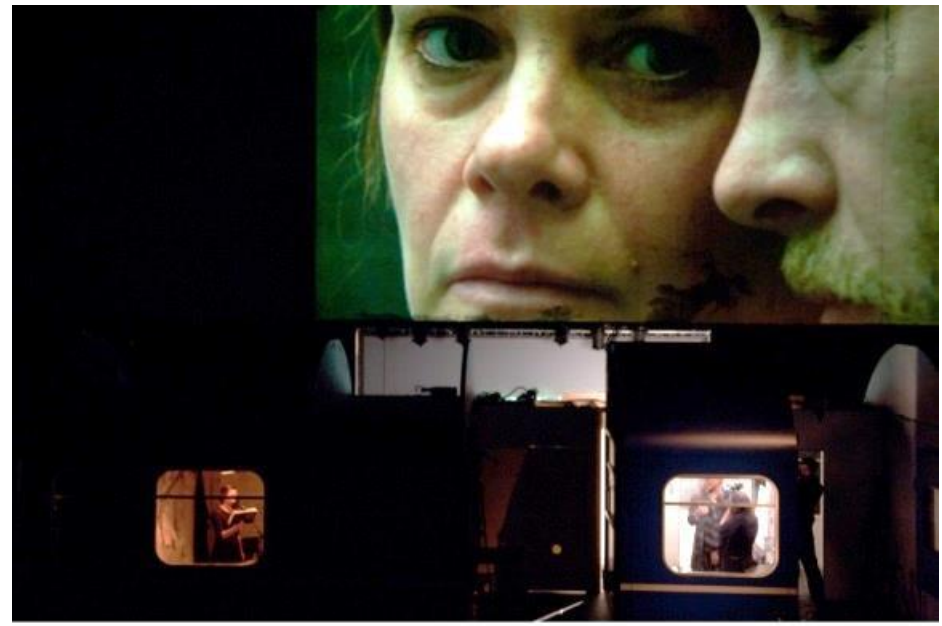

Figura 11:

Night Train (Katie Mitchell, 2013).

Não se produz a ilusão de que o ator é o personagem e de que aquilo está acontecendo. A não que o espectador faça parte da dramatização. Como no espetáculo "66 Minutes in Damascus", apresentado na "Bienal Internacional de Teatro", no TUSP em $2013^{11}$. Situados no lugar de turistas a passeio no Líbano, espectadores são vendados e colocados em um carro que circula por São Paulo simulando um sequestro. De posse dos terroristas, são questionados sobre uma suposta reportagem enviada sem permissão ao ocidente. Passam por cubículos onde estão presos políticos, torturados em troca de informação. O espectador vive, em vertigem, "na pele", as desventuras de um sequestro; e debate, com os "sequestradores" a situação política do seu país. Sucessivas pesquisas propõem uma quebra da "quarta parede" ou espaço da ficção, em troca de outros eixos onde o espectador se encontra tematizado. Teatro múltiplo, que não é o caso de detalhar aqui, mas é importante que as oposições sejam testemunhadas, pois se situam como paradigmáticas para a escolha dos materiais. O campo do Teatro Pós-dramático é um estimulo para a extração de anteparos no ateliê, mas também o arranjo da composição naturalista - que conta com uma divisão de foco entre interno e externo; entre cotidiano e relação; entre querer e agir; entre visualidade do pensamento e ação física.

Não apenas as múltiplas encenações pós-dramáticas podem nos servir como campo de extração (através de citações ou diluições, quando o material é transformado ou posto em relação), mas a sua teoria. Quando Robert Wilson se dispõe a defender o procedimento de colocar um sapo gigante em cena sem que este se articule ou evoque qualquer tipo de visualidade fabular, abre a perspectiva da experimentação. Quando o teatro pós-dramático traz materiais como areia, água, palha, argila, tinta, sangue (como

${ }^{11}$ Dirigido por Lucien Bourjeily especialmente para o LIFT Festival 2012, em Londres. 
vemos em Pina Bausch) sem que impliquem qualquer efeito de significação explicito na encenação, abre perspectivas da visualidade que se inscreve para além da inscrição na visualidade do drama. A presença dos materiais "nos causa" (nos engaja) sem que esteja inscrita na ficção onde a sua presença seria justificada.

2.1.3. A cena aponta para um lugar de não inscrição

$$
\begin{array}{r}
\text { O sublime produz necessariamente uma tensão } \\
\text { entre o entendimento e a imaginação, } \\
\text { a qual se lança sempre para além } \\
\text { do que o entendimento é capaz de abarcar. } \\
\text { O sublime relaciona o respeito à Lei } \\
\text { ao irrepresentável que ela barra. }
\end{array}
$$

(Maria Rita Kehl)

Lacan criou aforismos famosos como "o inconsciente é estruturado como uma linguagem” (LACAN, 1998, p. 144), sendo que, na linguagem, não se trata de relações unívocas entre significantes e significados, mas de deslizamentos (metonímias) e empilhamentos (metáforas), de maneira que um efeito de significação sempre se remete a outro.

\begin{abstract}
A primeira rede, do significante, é a estrutura sincrônica do material da linguagem, na medida em que cada elemento adquire nela seu emprego exato por ser diferente dos outros; é esse o princípio de distribuição que rege sozinho a função dos elementos da língua em seus diferentes níveis, desde o par da oposição fonemática até as locuções compostas. A segunda rede, do significado, é o conjunto diacrônico dos discursos concretamente proferidos, que reage historicamente à primeira, assim como a estrutura desta determina os caminhos da segunda. Aqui, o que domina é a unidade de significação, que revela jamais resumir-se a uma indicação pura do real, mas sempre remeter a uma outra significação (LACAN, 1998, p. 415).
\end{abstract}

O processo de deslocamento de significantes é também o movimento do desejo - que depende de um espaço vazio, de falha, de falta-a-ser do sujeito para manter-se circulante: "O desejo é a metonímia da falta-a-ser" (LACAN, 1998, p. 646). Este vazio nos leva às figuras do objeto $a$ - objeto inapreensível e sem imagem: "ele não é especularizável, ou seja, dele não se pode formar uma imagem (...); ele não é nomeável, ou seja, não pode ser reduzido a uma designação permanente e estável, que corresponderia, por exemplo, a uma espécie de fixação de sua significação" 
(DUNKER, 2006, p. 05) - com o qual Dunker trabalha homologias entre a arte e a psicanálise. Junto a Lacan, ele postula "figuras do objeto $a$ " na arte, que nos remetem a este lugar de não inscrição, a um impossível de imaginarizar. Estas figuras são: o vazio e o excesso que polui a obra (indicando a falta); o informe, a deformação, a anamorfose, a tematização dos limites da forma e do quadro; e uma espécie de descrença no olhar, implicados no estranhamento e despersonalização.

Trata-se de colocar em dúvida ou desacreditar do que se vê. Um sentimento de estranhamento e de despersonalização abala o juízo de existência. Não há nenhuma distorção da percepção, ela não é mais nítida nem menos intensa. Não há nenhuma obstrução da lembrança. Mesmo assim a experiência questiona o que vê, põe em dúvida o estatuto de realidade da imagem que se tem pela frente. A experiência estética poderia ser aproximada aqui de uma espécie de descrença no que se vê (DUNKER, 2006, p. 03)

Dunker destaca a anamorfose: conseguir enxergar uma forma apenas com certa posição do olhar (um jogo com a posição do olhar, com o que se pode ou não enxergar).

\begin{abstract}
A anamorfose ou anamorfismo é uma deformação reversível de uma imagem produzida mediante procedimento óptico (utilizando, por exemplo, um espelho curvo), ou por meio de um procedimento matemático. É um efeito perspectivo utilizado na arte para forçar o observador a um determinado ponto de vista preestabelecido ou privilegiado, desde o qual o elemento toma uma forma proporcionada e clara (Hassan, 2007, p. 04).
\end{abstract}

O exemplo clássico é a obra “Os Embaixadores”, de Holbein.
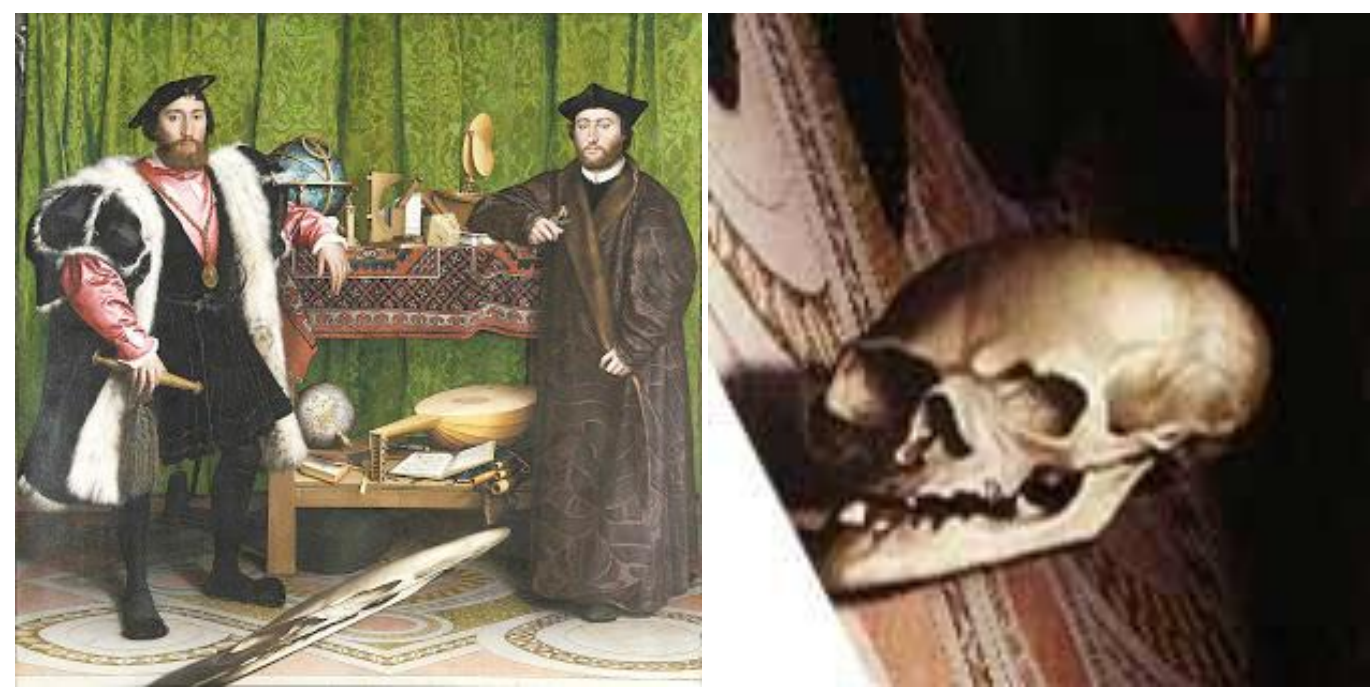

Figura 12: Os Embaixadores (Hans-Holbein, 1533) - e um detalhe do quadro 
Para Lacan, o quadro deve ser considerado como uma espécie de armadilha para o olhar. Para apreender a imagem, o sujeito deve colocar-se em uma dada distância da tela. Nesta posição ele reconstrói o caminho da perspectiva proposta pelo quadro, as imagens ganham forma, o espaço se organiza segundo uma geometria que permite incluir o ponto de vista do pintor (DUNKER, 2006, p. 04)

A cena teatral, além do efeito visual, implica um efeito de tematização do olhar - por exemplo, quando acontece no escuro, fora dos limites da luz; ou quando propõe o deslocamento do olhar do espectador para "ver outra coisa"; quando este recorta o que vê na cena poluída pelo excesso; ou a sobreposição dos enquadramentos o indaga e o faz circular, deslizar; ou, ainda, no efeito de vazio (de uma imensidão de água ou areia) que não lhe deixa ver outra coisa senão o mesmo. Ou trazendo para a cena a visualidade da rua; do sacrifício; a poética do ritual; do grotesco, da crítica, da paródia; da ironia e da tribuna; dos bastidores; da deformação e do sem sentido. São tipos (modalidades) de um excesso, de exacerbação. Porque não se reduzem à representação de um discurso, mas se abrem para uma produção que gira em torno de algo que não se pega - tocando-a em forma de afeto. Muitas vezes, no pós-dramático, diferentes visualidades implicam fissuras, coisas soltas se abrindo no espaço de uma escuta onde o espectador produz um não saber (a evidência de um limite).

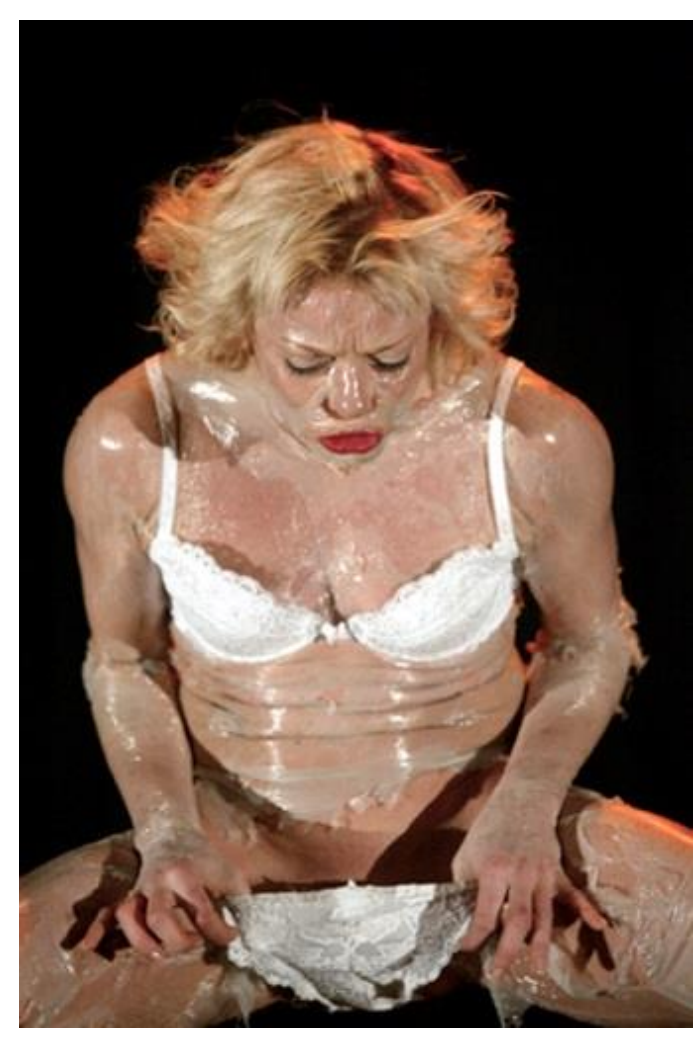

Figura 13: Elle était

et elle est, même

(Jan Fabre, 2004) 


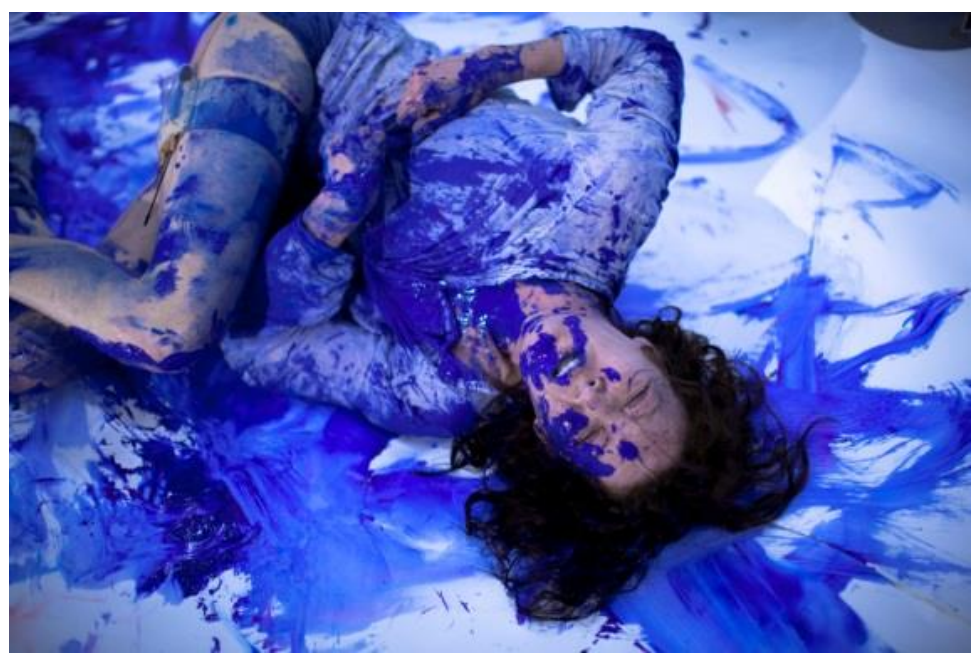

Figura 14: Cries and Whispers (Ivo Van Hove's, 2011)

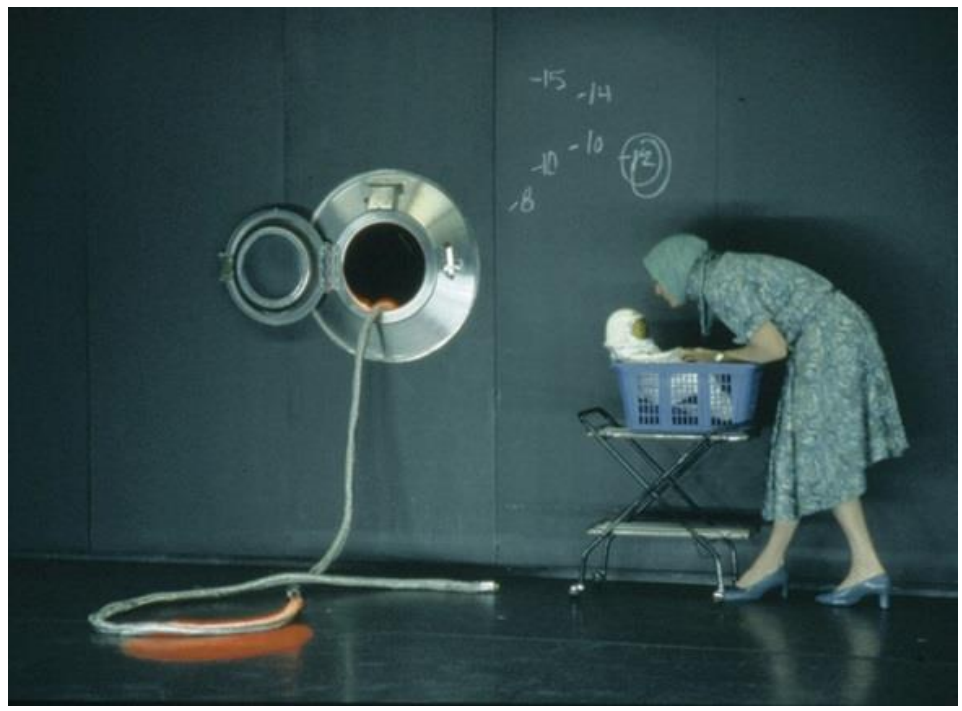

Figura 15: Far Side of the Moon (Lepage, 2012)

Um dos princípios que aparecem no pós-dramático é não justificar ou atribuir uma sobreposição de sentido às ações, mas operar por montagem - onde materiais são justapostos sem que impliquem uma totalidade. A inscrição (de um modo singular) na poética é avessa à necessidade de circunscrever a obra em um discurso que caiba dentro dos limites do imaginário (das relações imaginárias, de identificação) do eu. O esforço do sentido apaga o efeito estético. A sobredeterminação do sentido, através da palavra ou da imagem que se quer inteira, gera uma espécie de queda da visualidade.

Em “A Imagem entre o Olho e o Olhar" Dunker expõe uma passagem do texto de Freud "Sobre o mecanismo psíquico da desmemória" (1898), onde o psicanalista relata a tentativa de lembrar o nome de um pintor de afrescos: Luca Signorelli: “(...) com particular nitidez tinha ante meus olhos o auto-retrato do pintor - o rosto severo, as mãos entrelaçadas" (FREUD, 1988, p. 282). Quando consegue, por fim, lembrar-se 
do nome Signorelli, "a recordação hipernitida dos traços faciais empalideceu de imediato" (FREUD, 1988, p. 282). A imagem, antes intensa e carregada, torna-se pálida e rarefeita na medida em que o nome do pintor se completa (e com ele o sentido do esquecimento) ${ }^{12}$ :"A obstrução do sentido seria correlativa à intensificação da visualidade $e$, inversamente, a retomada do sentido, pela interpretação do esquecimento, corresponderia ao decaimento da visualidade" (DUNKER, 2006, p. 02).

Pensando na oposição entre sentido e efeito estético, no que diz respeito à ação, esta é tomada, no ateliê, como modalidade de enquadramento: visualidade (e não como sentido). Mesmo que se crie um enquadramento ficcional, a lógica do sentido pode ser tomada como um campo de extração de materiais isoláveis e passíveis de arranjo, mas não restringirá as escolhas. O que restringe as escolhas é a inscrição em uma poética da cena. Os limites da forma podem ser tematizados com as deformações e alterações das bordas corporais, o reenquadramento dos objetos e as projeções. Pode-se também dizer que a cena trabalha a descrença no olhar quando se aproxima de um efeito de alucinação que Roubine postula o "como se tivesse acontecendo"; o "como se fosse verdade". Ou a desconfiança do que se vê quando se propõe a imagem alucinatória. Testemunha-se a figura do excesso na multiplicação de objetos, nas alterações do tempo, na exacerbação do afeto; defasagem entre enquadramentos justapostos; ou uma repentina descoberta do olhar capturando algo no espaço-tempo (cênico ou da imaginação). $O$ fato de diluir-se a forma do enredo pode ser um viés da questão dos limites da forma. A encenação ofusca as relações intersubjetivas a serem representadas e inscritas no enredo. Há uma oposição entre visualidades que empalidecem ou evocam outras. Esta é uma busca cuja estratégia é: diálogo, extração de anteparos, arranjo, corte.

\footnotetext{
${ }^{12}$ A memória advém da cadeia associativa. Freud lembra-se de Botticelli e Boltrattio (outros dois pintores). Em seguida, a repetição da sílaba "bo" o leva à Bósnia Herrzegovina, que o leva a Herr: maneira pela qual os médicos se referem aos pacientes para comunicar a morte: "A reconstrução se completa pela lembrança de que na cidade de Trafoi - nome próprio contido em Boltrattio - Freud recebera a notícia do suicídio de uma paciente acometido por uma perturbação incurável" (DUNKER, 2006, p. 02).
} 
2.1.4 Fazer ver outra coisa

O teatro é uma arte e ao mesmo tempo talvez mais que uma arte (V. Meyerhold)

Um dos motes que norteou a construção plástico-corporal exacerbada durante o século XX foi uma libertação dos valores burgueses, seus mecanismos de determinação e institucionalização. Vemos, em projetos de Meyehold, Artaud, surrealistas, dadaístas ou Bauhaus, de Brecht e Teatro do Absurdo, uma espécie de fazer ver o que não está sendo visto; para além de um olhar institucionalizado, habituado, comum. Uma espécie de "quebra do olhar". Também no naturalismo de Antoine o objetivo era fazer ver o que não estava sendo visto em um teatro escravizado pelas idealizações românticas e pelos dramalhões melodramáticos. Antoine criou um retrato da prostituição sem a idealização romântica de "Dama das Camélias", provocando repulsa. Foi difícil para o público ver a crueza e deparar-se com "o desgosto que causavam as cenas desagradáveis de uma mulher que apodrecia consumida pela variola" (BUSNACH, 1884, p. 205 apud FARIA, 1998, p. 39). A Dama das Camélias (1851) foi o primeiro grande sucesso da escola realista. Mas, segundo Marvin Carlson, apesar de contribuir para "uma sugestão do realisto fatia-de-vida", Alexandre Dumas Filho se diferenciava dos realistas subsequentes e do naturalismo, graças à "dedicação à moral do drama”. Zola tomava-o por idealista. "Enquanto Dumas queria corrigir o homem, Zola queria examiná-lo" (CARLSON, 1997, p. 267-269). Após a Primeira Grande Guerra as grandes narrativas (o discurso sobre o mundo) desabam. Inicia-se a trajetória que vemos em movimento retroativo, centrada nas oposições paradigmáticas: à atuação dramática e à atuação naturalista - das quais nos valemos no ateliê.

Podemos dizer que, no projeto de inscrever a cotidianidade em cena (presente no naturalismo e que muitas vezes se confunde com ele) estão postos: vertigem, delírio e uma espécie de "não acredito no que vejo": "descrença no olhar". A cotidianidade do corpo, quando se investe em outra poética que não é a da deformação ou abstração das formas, também pode estranhar. Já um arranjo de Meyerhold tem outros materiais para estranhar; uma espécie de choque que se contrapõe ao universo burguês evocado pela palavra. Um exemplo é a sua montagem de "Casa de Bonecas" de Ibsen, em 1922, 
designada com o subtítulo "A História de Nora Helmer ou Como uma mulher preferiu a independência e o trabalho ao veneno da família burguesa". Graças ao entulho que compõe o cenário, a frase "Me sinto confortável na minha sala diante da lareira", de Helmer, resulta irônica (Abensour, 2011). Já na montagem de “As Auroras” em 1920, quando um dos personagens vai proferir o hino de vitória, Meyehold introduz uma notícia esperada pelo povo: o Exercito Vermelho se apodera de Perekop e coloca fim à guerra civil - o que causa comoção na plateia. Neste mesmo espetáculo os atores se dirigem ao espectador convocando a sua opinião (idem). São materiais que podemos misturar não na extração direta em diferentes arranjos meyerholdianos, mas na medida em que estão na cultura inscritos e os encontramos contemporaneamente. Mas talvez o principal campo de extração meyerholdiano seja o grotesco, que propunha a partir de estudos dos Caprichos (desenhos) de Goya, Daumier e Callot - figuras que não apenas “incitam a imaginação" (como dizia), mas se instalam nos corpos: criação estranhada (em oposição ao realismo) quando o ator assemelha-se ao bufão.

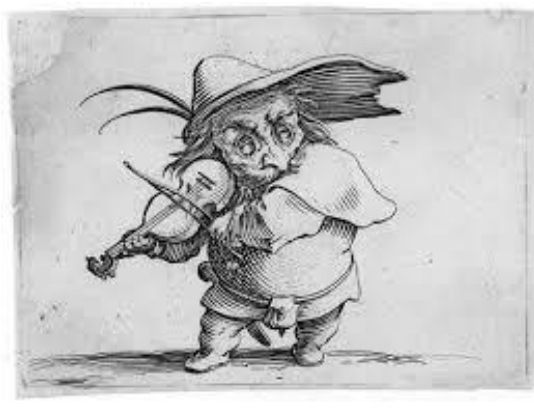

Callot

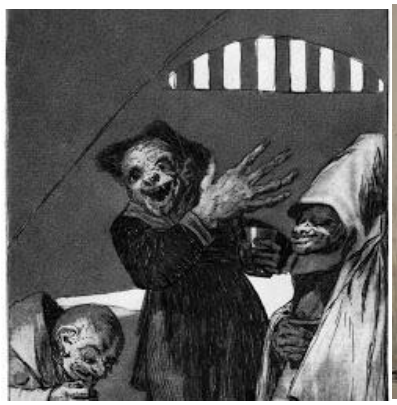

Goya

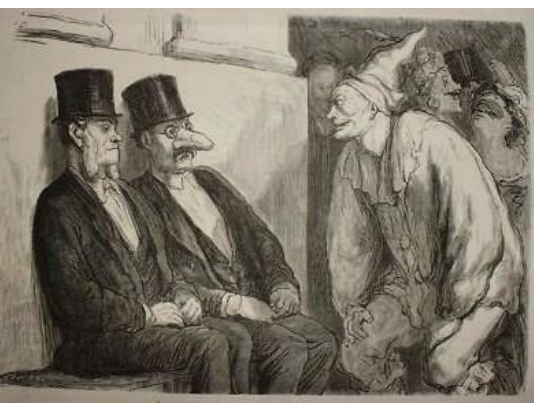

Daumier

Figura 16: Anteparos propostos por Meyerhold aos atores

É possível testemunhar a função do enquadramento também através da música: "no sentido da restrição, pois a música intervém no tempo e o isolamento numa pequena plataforma restringe o espaço” (ASLAN, 1994, p. 152) - e outros materiais. Segundo Aslan, Meyerhold "restringe a ação com pausas entre as falas, posturas estáticas ou intrusão de pantomimas; subverte o encadeamento, impõe entonações insólitas, com a voz fabricada" (idem). Kirby associa o ator meyerholdiano a uma marionete animada. Percebe-se uma oposição ao corpo mimético realista, onde as noções de naturalidade e cotidianidade estão implicadas. Em "Inspetor Geral” (1926), ele substitui personagens por manequins; utiliza telas alternando a atuação filmada e ao 
vivo; coloca passagens de outros textos no espetáculo ("Os Jogadores", "As Almas Mortas" e "As Histórias de S. Petersburgo", também de Gogol); acrescenta personagens mudas; constrói um coro que não havia; cria figuras episódicas; transforma monólogos em diálogos; coloca o mesmo ator interpretando vários personagens para frustrar as possibilidades de identificação (Abensour, 2011).
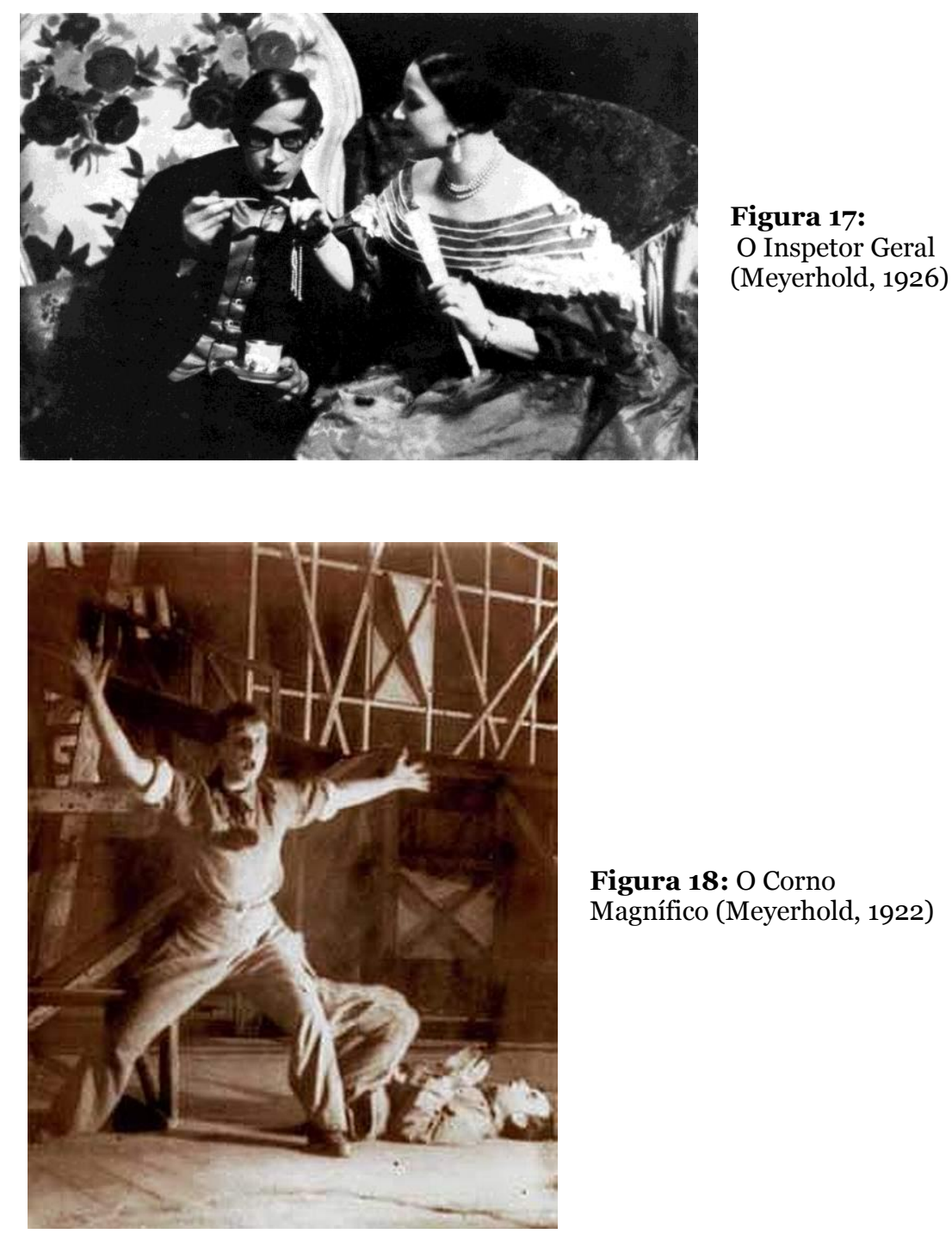

Figura 18: O Corno

Magnífico (Meyerhold, 1922)

Outro arranjo paradigmático, podemos encontrar em Artaud. Ao mesmo tempo em que designa a submissão ao texto como "barco fúnebre", critica a visualidade estéril da mise-en-scene; postula um teatro independente da literatura, apesar de tomar grandes textos como referência de algo que se deve evocar para além da mimese da realidade. $\mathrm{O}$ teatro deve possibilitar a "exploração de infinitos deslocamentos interiores" e para isto é necessário se libertar da representação e encontrar a vida: "Reatralizar o teatro $e$ 
relança-lo na vida" (ARTAUD, 2008, p. 26). É o objetivo de Artaud, se opondo ao naturalismo com suas tendências humanistas. Encantou-se pelo teatro balinês graças a sua "impessoalidade":

Tudo nos atores é impessoal - talvez por se diferenciar radicalmente do naturalismo e sua construção pessoal. Os gestos "respondem a uma espécie de matemática (...) nessa despersonalização sistemática, nessas expressões puramente musculares que são como máscaras sobre o rosto, tudo tem o seu significado, tudo produz o máximo efeito (ARTAUD apud MIRALLES, 1979 , p. 45-46)

A vida não está presente na representação do indivíduo em cena (mas em algo que se dá no excesso). O encenador deve: "fixar as imagens que nascerão em nós nuas, excessivas e ir até o extremo destas imagens" (ARTAUD, 1008, p. 27) - algo similar ao processo de associações de imagens (internas) que percebo no ateliê. Continuando com Artaud, ele propunha: um teatro "raro", que se pode encontrar no circo, mas que, no entanto, diz do espírito (e se estabelece como uma metafísica). O espectador não deve "ir lá para ver, mas para participar” (idem) - experimentar "a angústia metafísica que as cenas representadas provocarão” (ARTAUD apud MIRALLES, 1979, p. 41) ou "a insônia febril, o passo dos corredores, o salto mortal e a potência de uma bofetada" (GLUSBERG, 2007, p. 12) já presentes no futurismo de Marinetti. Teatro como "praga libertadora que desencadeia poderes e possibilidades sombrias" (CARLSON, 1997, p. 381); A peça radiofônica "Para Acabar de Vez com o Juízo de Deus" (Artaud, 1948) testemunha a pesquisa com a sonoridade: ganidos, gritos, ruídos, alterações radicais de altura e volume - além de uma visualidade do transe e do ritual; espécie de possessão vestígios do expressionismo:

\footnotetext{
O isolamento e ampliação do traço em detrimento do todo; o uso da voz para agir sobre o espectador; descargas sonoras e visuais; a palavra ritmicamente articulada; diálogos sem ordem; a presença da poesia e prosa; gestos isolados e estilizados; o corpo flexível e desarticulado do ator; o trabalho com as zonas de tensão, as mãos crispadas, os gestos cortando o espaço; a ideia de coreografia, com batidas de pés, tremores, crispações, projeções da cabeça e dos braços para trás ${ }^{13}$
}

Tal como em “O Dibuk” (Vankhtangov, 1922), há no corpo uma desconstrução do humano:

13 SALlES, Nara. Teatro Expressionista. Portal São Francisco: História do Teatro. Disponível em: http://www.portalsaofrancisco.com.br/alfa/historia-do-teatro/teatro-expressionista-3.php Acesso em 16/01/2014. 
Gritos guturais, guinchos, salmodiar doloroso, musicalidade e uma interpretação gestual com balanço de cabeça e pernas, torso lançado para trás e/ou com as costas arqueadas, gestos largos e intensificados. Havia uma dança dos mendigos que chamou a atenção por sua força encantatória, um balé grotesco, macabro, com braços que se agitavam como morcego (idem).

E na palavra também há desconstrução; vazão ao jogo do som e ao vazio, hiato vertiginoso quando não se evoca mais um sentido: "Kré É preciso que tudo puc te Kre esteja arrumado puk te pek por um fio li le kre numa ordem pek ti le e fulminante kruk pte",14

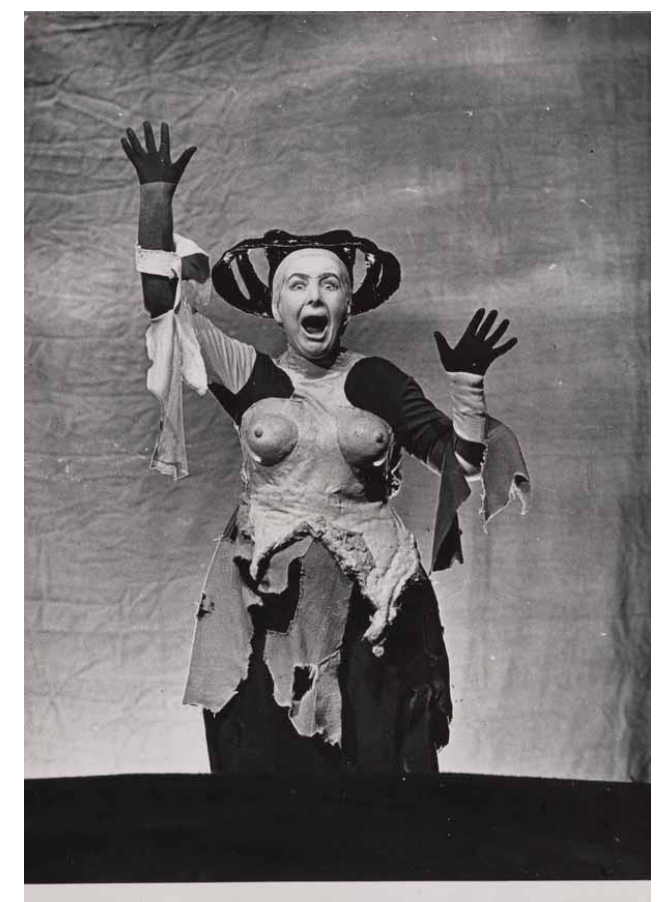

Figura 19: Montagem de "O Rinoceronte" (Ionesco) dirigida por Tadeusz Kantor (1961)

O absurdo da linguagem encontra lugar também "no mais bem sucedido teatro de vanguarda do Século XX" segundo Carlson: “O 'Absurdo' tornou-se um lema literário da moda, a que diversos escritores recorreram para classificar o novo drama, a despeito dos protestos dos dramaturgos assim rotulados" (CARLSON, 1997, p. 399). A dramaturgia de Ionesco, Beckett e Adamov foi assim designada por Martin Esslin a partir da "literatura do absurdo" - título inspirado no "Mito de Sísifo" (1951) de Camus, por tematizar o eterno (e absurdo) recomeçar humano. Carlson define o "Teatro do Absurdo" como anti-realista: "Um novo estilo de drama anti-realista na França que

\footnotetext{
14 Trecho de "Para Acabar de Vez com o Juízo de Deus". Fonte: KIFFER, Ana. Artaud, Momo ou Monstro? Centro de Estudos Claudio Ulpiano, 2010. Disponível em: http://claudioulpiano.org.br.s87743.gridserver.com/?p=258 (Acesso em 06/o1/2014)
} 
haveria de tornar-se o teatro de vanguarda mais bem-sucedido que o século já produzira" (idem). Os dramaturgos preferiam "Teatro da Erosão" ou "Teatro Abstrato":

Puro drama. Antitemático, antiideológico, anti-social-realista, antifilosófico, antipsicologia de boulevard, antiburguês - a redescoberta de um teatro livre" - contra "as convenções aceitas do teatro francês tradicional, a ênfase na palavra, o vínculo de causa e efeito, a tendência ao realismo e o desenvolvimento psicológico do caráter (IONESCO, 1964, p. 216-217 apud CARLSON, 1997, p. 400).

A visualidade do nonsense aparece, junto a traços do Music Hall e Vaudeville. A influência se estende a Buster Keaton, Charles Chaplin, Irmãos Marx, Joyce e Kafka; propriamente um híbrido, cuja produção de estilo é marcante. Outros dramaturgos são nomeados "absurdos": Arrabal, Jean Genet, Harold Pinter, Tom Stoppard, Friedhich Dürrenmatt, Edward Albee, Jean Tardieu. O marco inicial desta produção se deve a Beckett ("Esperando Godot", 1949) e Ionesco ("A Cantora Careca" e "A Lição", ambos de 1950). Ionesco afirmou que "As Cadeiras" era uma tentativa de "alargar as fronteiras atuais do drama". Um debate com o campo dramatúrgico então institucionalizado, para instalar outra lógica na construção dramática - propondo uma espécie de abstração que:

(...) purifica a ação dramática do que lhe é intrínseco: enredo, características acidentais dos personagens, seus nomes, posição social e contexto histórico, razões aparentes do conflito dramático e todas as justificativas, explicações e lógica do próprio conflito para obter um conflito abstrato sem motivação psicológica (idem).

Uma questão que se abre é a construção do estilo de atuação para as peças do Absurdo - com a estilização do gesto, absorvendo a influência dos mímicos (Jean-Pierre Barrault foi o primeiro a dirigir "O Rinoceronte"). Outra questão é o divórcio entre a palavra e o mundo. A palavra esvazia-se; é a linguagem que é absurda. "A Cantora Careca" foi criada a partir de um manual de inglês, com frases do tipo: "Eu não tenho o chapéu do meu vizinho, mas tenho a bengala da minha tia”. A gratuidade é visível - o que a torna cômica. Segundo Ávila, Ionesco "denuncia o absurdo de certa linguagem cotidiana, em que as palavras, demasiado carregadas de significações as mais diversas, perderam o seu valor e passaram a não significar coisa nenhuma",15. Além do

15 AVILA, Norberto. Sobre o Teatro de Ionesco. Paris, s/d, p. o1. Disponível em: http://www.yumpu.com/pt/document/view/13037077/n-quando-nicolas-bataille-apresentava-a-umaplateia-quase-a- Acesso em 08/01/2014. 
desgaste da linguagem cotidiana, a visualidade das personagens se quebra. Elas se decompõem no suporte de uma voz, uma fala vazia.

\begin{abstract}
Ai! As verdades elementares e sábias que eles trocavam, encadeadas umas às outras, tinham se tornado insanas, a linguagem se desarticulara, os personagens se descompuseram; a fala, absurda, se esvaziara de seu conteúdo e tudo terminava por uma briga cujos motivos eram impossíveis de saber, já que meus heróis disparavam não réplicas, nem mesmo pedaços de frases, nem palavras, mas sílabas, consoantes, vogais!... Para mim, tratava-se de um tipo de desmoronamento do real. As palavras tinham se tornado revestimentos sonoros desprovidos de sentido; os personagens também, é claro, esvaziaram-se de sua psicologia e o mundo me aparecia numa luz insólita, talvez em sua verdadeira luz, além das interpretações e de uma causalidade arbitrária (IONESCO, 2006, p. 247-248 apud OLIVEIRA, 2009, p. 05)
\end{abstract}

Aqui a cotidianidade é avessa à construção do drama. Os personagens:

(...) não sabem mais ser, eles podem "se tornar" qualquer um, qualquer coisa, uma vez que não sendo, eles são apenas os outros, o mundo do impessoal, eles são intercambiáveis: pode-se colocar Martin no lugar de Smith e viceversa, não se notará (idem).

Em "As Cadeiras" um casal de velhos vive numa torre no centro de uma ilha. Preparam uma grande recepção para a qual convidam personalidades. Passam o tempo enfileirando cadeiras para convidados que não virão. Deparamo-nos com o vazio como um fundamento da experiência estética. Ionesco afirma sobre a sua dramaturgia: "é a expressão de uma angústia e de uma interrogação para a qual eu próprio aguardo uma resposta"16 "Rinoceronte", no entanto, está atrelado a um sentido: o sentido de uma crítica ao nazismo e a aversão a qualquer tipo de histeria coletiva. As pessoas viram rinoceronte e, tal como nos regimes totalitários, são contagiados e massificados. Resta Bérenger, simbolizando a resistência da condição humana: "A mim é que vocês não pegam! Eu não vos seguirei! Eu não vos compreendo! Continuarei como sou. Sou humano, um ser humano!"

Também as peças de Beckett, como "Esperando Godot" (que estreou em Paris em 1952 sob a direção de Roger Blin) e "Fim de Jogo" (que estreia em 1957 no "Royal Court Theatre"), marcaram pela visualidade do vazio. O velho e cego Hamm com seu serviçal Clov (cujo encadeamento foge a qualquer justificativa, se impondo como puro

16 AVILA, Norberto. Sobre o Teatro de Ionesco. Paris, s/d, p. o1. Disponível em: http://www.yumpu.com/pt/document/view/13037077/n-quando-nicolas-bataille-apresentava-a-umaplateia-quase-a- Acesso em 08/01/2014. 
efeito de grafia). Embora a relação entre os dois se estabeleça, já não se sabe se, há três minutos, Clov fez, exatamente, o que está novamente a fazer. Há críticos que pontuam a influência de James Joyce na obra de Beckett. Segundo Badiou "a obra de Beckett se abre para o acaso, para os incidentes e, portanto, para a ideia de sorte" - tal como a de Joyce. 'Em 'O Inominável' (romance de 1949) lemos: 'ninguém me obriga, não há ninguém, é um acidente, é um fato ", (BADIOU, 2003 apud AMARANTE, 2009, p. 01). Segundo Amarante:

Beckett e Joyce compartilham uma mesma desconfiança para com a linguagem, como se verá à frente. Sendo que essa linguagem, da qual se origina uma fala incessante, tende a gerar, na obra de ambos, personagens obscurecidos pela voz, ou seja, personagens sem corpo (...). Esses personagens, feitos de linguagem, acentuam e traduzem a atmosfera de sonho, de devaneio de suas obras (AMARANTE, 2009, p. 02).

Poderíamos completar: "atmosfera de errância e incerteza". "Estou no quarto de minha mãe. Sou eu que moro lá agora. Não sei como cheguei lá. Numa ambulância talvez" (idem). Descorporificação: "VLADIMIR: Veja só! Você, aqui, de volta. / ESTRAGON: Estou?”. Segundo Badiou: “Tudo se reduz à voz. Plantado num jarro ou cravado numa cama de hospital, o corpo, cativo, mutilado, agonizante, é apenas o suporte quase perdido de uma fala” (BADIOU, 2003 apud AMARANTE, 2009, p. 05).

\footnotetext{
Sou de palavras, sou feito de palavras, das palavras dos outros, que outros, e o lugar também, o ar também, as paredes, o chão, o teto, palavras, o universo está todo aqui, comigo, sou o ar, as paredes, o emparedado, tudo cede, tudo se abre, anda a deriva (...) (idem)
}

A determinação de uma voz enquanto o corpo se dilui é radicalizada na peça de 1973 "Não Eu”: apenas uma boca iluminada em cena. Há fala compulsiva. No entanto, não "do Eu". A visualidade do Eu se perde. Aqui se chega à concretização de um projeto - e talvez Carlson tenha razão em afirmar que o Teatro do Absurdo é o mais bem sucedido movimento de vanguarda do século XX. Se a história do teatro no século $\mathrm{XX}$ se organiza em torno da recusa de um realismo; da visualidade de uma diegese fechada onde indivíduos se encontram implicados em relações intersubjetivas a serem representadas; aqui não há indivíduo; não há "eu" corporificado. O fato de não haver um corpo inteiro é representativo. No entanto, nos diversos movimentos, que primaram por linhas corporais (como a Bauhaus), apesar de o corpo estar presente, extrapola-se a visualidade do $\mathrm{Eu}$ - o que nos faz concluir que, em cena, o indivíduo é uma construção, 
evocação (na qual se pode investir ou não). No caso do drama é nisto que se investe - e na progressão da relação e conflito com o mundo. No caso da poética estranhada é isto que se desmancha. Ao mesmo tempo, Roubine abre a perspectiva de um olhar para a atuação naturalista com o reconhecimento de que também pode estranhar, na medida em que causa a vertigem do olhar. Assim, temos dois campos de extração de anteparos para o jogo cênico, desmembramento e diferenças para construir jogos de enquadramento.

\subsection{Corte e Encontro de Materiais para um Dizer: A Poluição de "Casa"}

Com minha fome de lobo amaino

o meu corpo de ovelhinha

(Giuseppe Ungaretti)

\subsubsection{Encontro Fortuito e Outros Enquadramentos: "A Prisão"}

Parto do encontro (e composição) entre diferentes visualidades para os arranjos de "Casa", constituindo um arranjo externo - uma relação com o espaço que enquadre o ator em cena. Anteparos advindos da pulsão de encenar (mais que de contar a história). O enquadramento ficcional (a articulação na fábula) pode se dar a posteriori enquanto algo fica de fora, escapa. À operação de evocar, Rancière chama "representação".

(...) é essencialmente um fazer ver, cabe-lhe pôr ordem no visível desdobrando um quase visível em que se vêm fundir duas operações: uma operação de substituição (que põe "diante dos olhos" o que está distante no espaço e no tempo) e uma operação de manifestação (que faz ver o que é intrinsecamente subtraído à vista) (...) $\mathrm{O}$ excesso denuncia o jogo duplo da representação. Isto é: por um lado, a palavra faz ver, designa, convoca o ausente, revela o oculto. Mas esse fazer ver funciona de fato na sua falta, no seu próprio retraimento (RANCIÈRE, 212, p. 123).

Um "fazer ver" o que está "substraído à vista" está implicado como operação de um arranjo em "Casa" na medida em que uma escada faz ver um homem que prende a menina (relação presente na história evocada) - um significante através do qual as duas visualidades se articulam. Mas algo da plasticidade cênica está para além desta que ela evoca. 


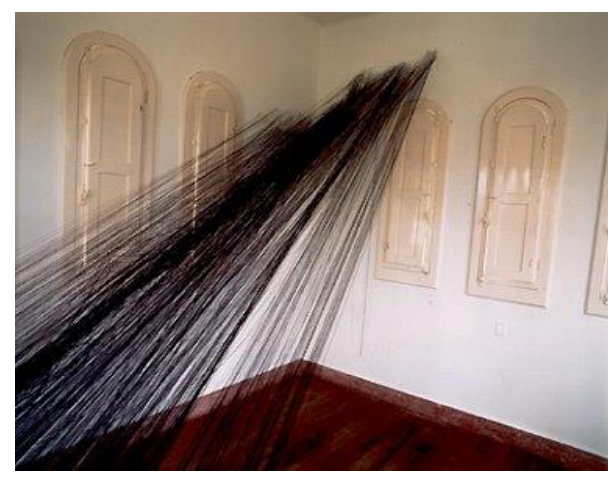

Figura 20: Obra

de Edith Derdyk

A escada surgiu de um encontro fortuito (acaso, sorte), graças à incidência de uma obra de Edith Derdyk ${ }^{17}$. As linhas que a artista fixava na parede evocavam um tipo de corpo estranho denso que me espantou, bem como as centenas de vezes que ela subia e descia a escada para fixá-lo. No outro dia, levo para a USP uma escada sem saber o que fazer com ela. Tentando me prender na parede com uma fita crepe (graças a um anteparo extraído de Pina Bausch) enquanto repetia "Ela está presa! O amor a prende!", ouço de Evinha Sampaio ${ }^{18}$ : "E se você entrasse na escada?"

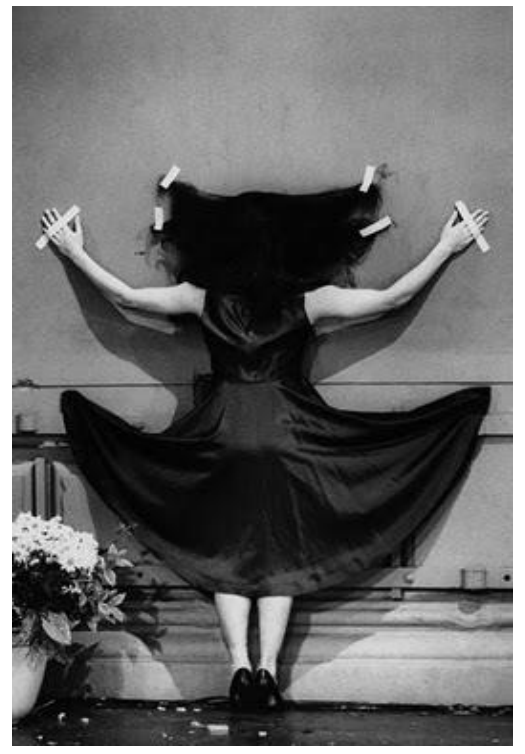

Figura 21: Anteparo extraído de Bausch:"Ela está presa"

Na projeção, está uma figura masculina que parece o meu avô. A posteriori, a fotografia encontra um enquadramento ficcional, evocado pelas palavras do romance de Nelson Rodrigues: "Minha Vida", escrito nos Anos 40 sob o pseudônimo Suzana Flag.

\footnotetext{
17 Desde 1981 expôs no MASP, MAM, MAC, Pinacoteca do Estado e SP, CCBB-RJ, Instituto Tomie Ohtake e outras - e países como Alemanha, México, Colômbia, Suécia, Suíça, França, Dinamarca. Prêmios: FUNARTE/2012; artista residente no The Banf Centre/Canadá 1997; Porto Seguro 2004; Fundação Vitae 2002; artista pesquisadora residente em Bellagio Center/The Rockefeller Foundation, Itália 1999; artista residente pelo MAC-USP/Vermont Studio Center, USA 1993 e outros Ver mais em: http://www.edithderdyk.com.br/

${ }^{18}$ Evinha Sampaio é também pesquisadora no CEPECA. Participou ativamente da pesquisa.
} 
Não escolhi a fotografia para representar o tio de criação que prende a garota; tampouco para representar meu avô, mas porque evoca algo rude e triste. Vê-se um empilhamento de significantes (presentes na ausência) a se perder de vista. O espectador associa outros. Eu tenho os meus, que entram no arranjo e incidem sobre mim; reverberam histórias passadas, que posso escrever ou fantasiar, explorar a incidência para construir algo que preencha (ocupe) o olhar em cena (ou que me traga pequeninas reverberações).

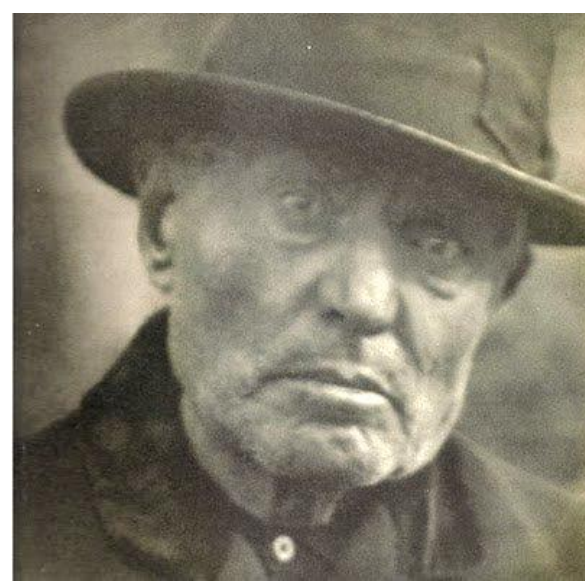

Figura 22: Fotogravura (1917) de Paul Strand (1890-1976) na projeção.

A escada assume um valor de significante, pois é algo "diferente" do homem e que o substitui, criando um enquadramento ficcional e, ao mesmo tempo, enquadrando as impressões digitais em um espaço cênico (pois impõe limites para os movimentos, constituindo um jogo de oposição com eles).

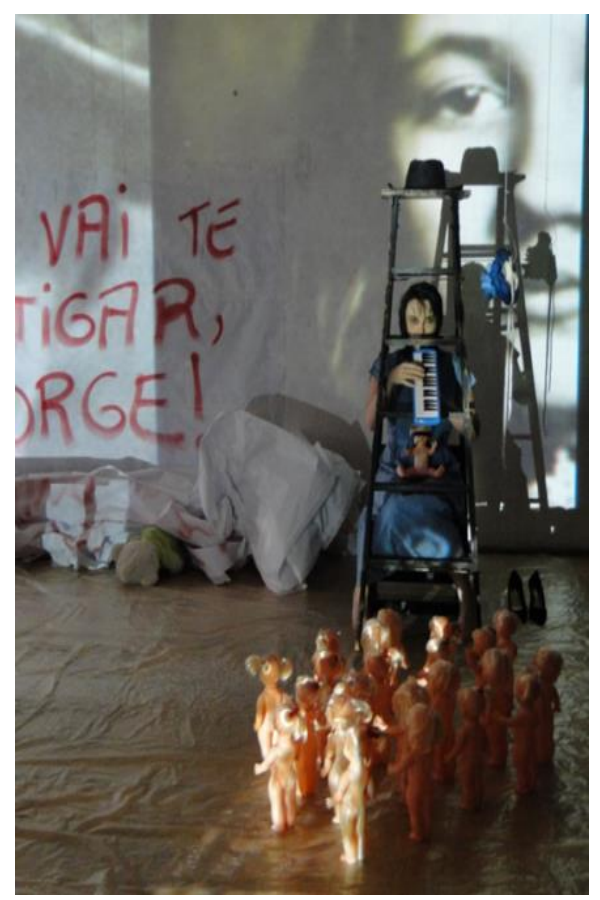

Figura 23: A menina presa no homem toca "Xote das Meninas" na escaleta. 


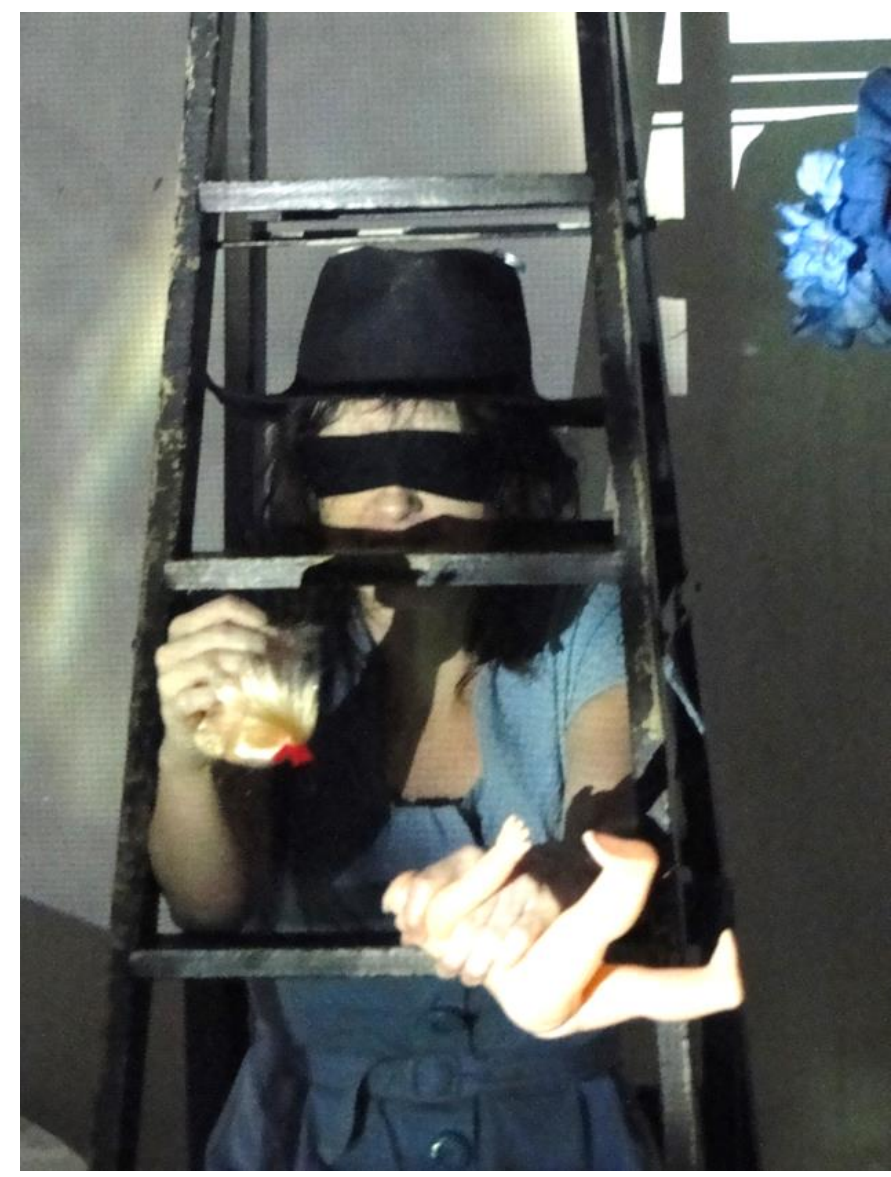

Figura 24:

Boneca evoca a menina sendo repreendida.

Há diálogo e certa progressão dramática, extraída do romance.

ELA (Como homem, firme, olhando para a boneca): Você tem tanto medo de mim assim? (Como menina, suave, olhando para cima para falar com ele. Balbuciante) Tenho. (Como homem, olhando para a boneca, firme) Eu te fiz alguma coisa? (Como menina, olhando para cima, suave) Me trouxe para cá. (Firme) Quer saber de uma coisa que eu não disse nunca? (Suave) Sim. (Firme) Eu amo você. (Suave) Ama como?

Como se fosse o homem, a narradora conversa com a boneca que está no colo. O revezamento da direção do olhar é sustentado pelo revezamento das palavras "firme" e "suave" (falas internas) - e um imaginário: para cima sou "eu"; para baixo sou "tio". A tensão da progressão dramática (do diálogo) é reforçada pela música extraída de "A Liberdade é Azul" (Kieslowski, 1992), mas sua dissonância estranha. O homem fala que ama a menina e ela desce a parte de cima do vestido, deixando os seios à mostra. A interpretação sublinha a ação: um ato de oferecimento do corpo. A ação, que não está no enredo rodrigueno, apareceu na improvisação com o pré-jogo desta cena. A um passo de evocar a figura da avó junto à fala "Miserável! Deus há de arrancar teus olhos!", coloco 
a venda, que evoca a sua cegueira, seguindo a narrativa. Mas arranco a cabeça da boneca, ação que escapa, está fora ou além desta.

A cena é lenta. A música do filme de Kieslowski preenche o enquadramento temporal, alargando-o. Há sobreposições: diálogo e música; música e melodia na escaleta (“O Xote das Meninas", de Luiz Gonzaga). A ação de tocar foi deslocada de outro arranjo. Associei-a no momento de ver Rapunzel (e a melancolia de alguém que toca porque não tem nada a fazer). Ela já estava no processo e deslizou para cá. Em jogo está o diálogo com a cultura cênica: cenas com instrumentos me fascinam. Opto pelas sonoridades sobrepostas: é possível justapor melodias (harmônicas ou dissonantes), assim como é possível justapor visualidades internas (fazendo as vibrar e dividindo o foco entre elas).

(Firme, com sofrimento) Eu amo você. (Pausa. Ela tira a alça do vestido e mostra os seios em um ato de oferecimento ao tio. Na sequência aparece a avó) "Deus vai te arrancar os olhos Suzana!" (Arranca a cabeça da boneca e deixa cair junto ao corpo. Ela grita com as mãos na boca, em reação. Suavemente chega ao parapeito e olhando para cima) O senhor seria capaz de me matar? (Como homem) Se você me traísse mataria.

Definido o arranjo dos anteparos de enquadramento externos (escada, chapéu, boneca, escaleta, música, projeção), antes da improvisação diante do olhar do CEPECA, o pré-jogo (encadeamento das falas internas e externas) é repetido até a memorização completa. Não há o treinamento da partitura cênica antes da improvisação, mas do préjogo. Na hora do improviso, a escada prende (me enquadra), assim como faz a projeção. Procuro os pontos luminosos para me posicionar, o que divide o foco e se configura como uma "instrução de jogo" (categoria dos Jogos Teatrais de Spolin). Parte do foco se mantém situado nos pontos de luz (que me remetem a um estado de incidência); a outra parte se situa na escuta das impressões digitais, que surgem dos impulsos treinados do pré-jogo (treinados na imobilidade da repetição da escrita do pré-jogo) e que encontram o enquadramento cênico na hora em que estou sob a incidência do olhar do outro. Deixo-me levar. A música invade os ouvidos, situando também parte do foco. A divisão do foco abre a área de vulnerabilidade para os impulsos se instalarem. 
de me celta monere

(5)

Ele. Do Dre certa manuen cons?

Ele. Ewano rocê. Aro.

Tine o plicopo de berree

Solta a bruce. fru cai.

the s roupa.

Coloco o chapéi fianue.

ollo pl de e peiguto

ofula sine agror de we neth?

El: fe ve me taisse matare.

(cichar latirite)

* A ptonare fillhe 8

Figura 25: Manuscrito que passou pela repetição até a memorização

42 


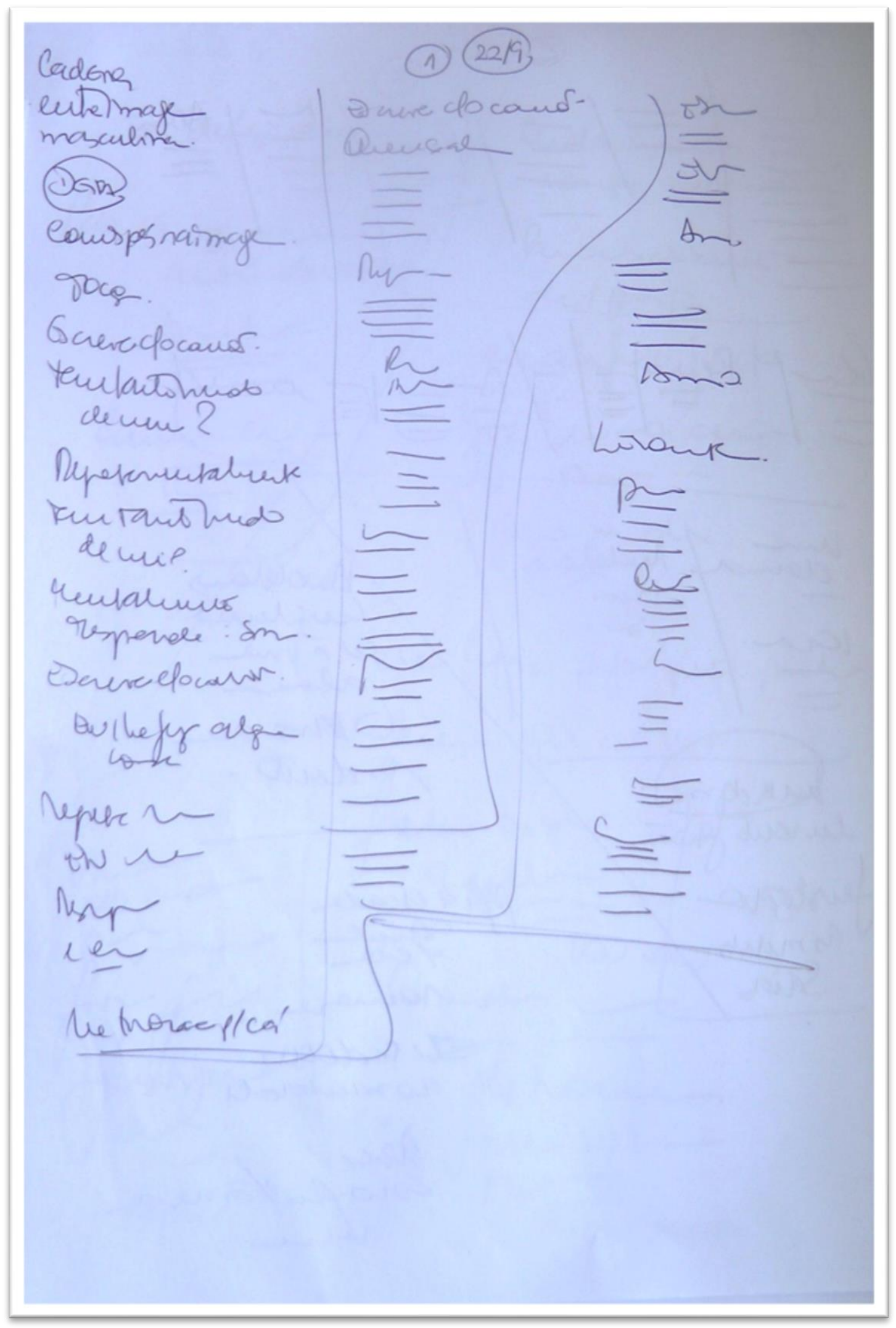

Figura 26: Manuscrito que passou pela repetição até a memorização 


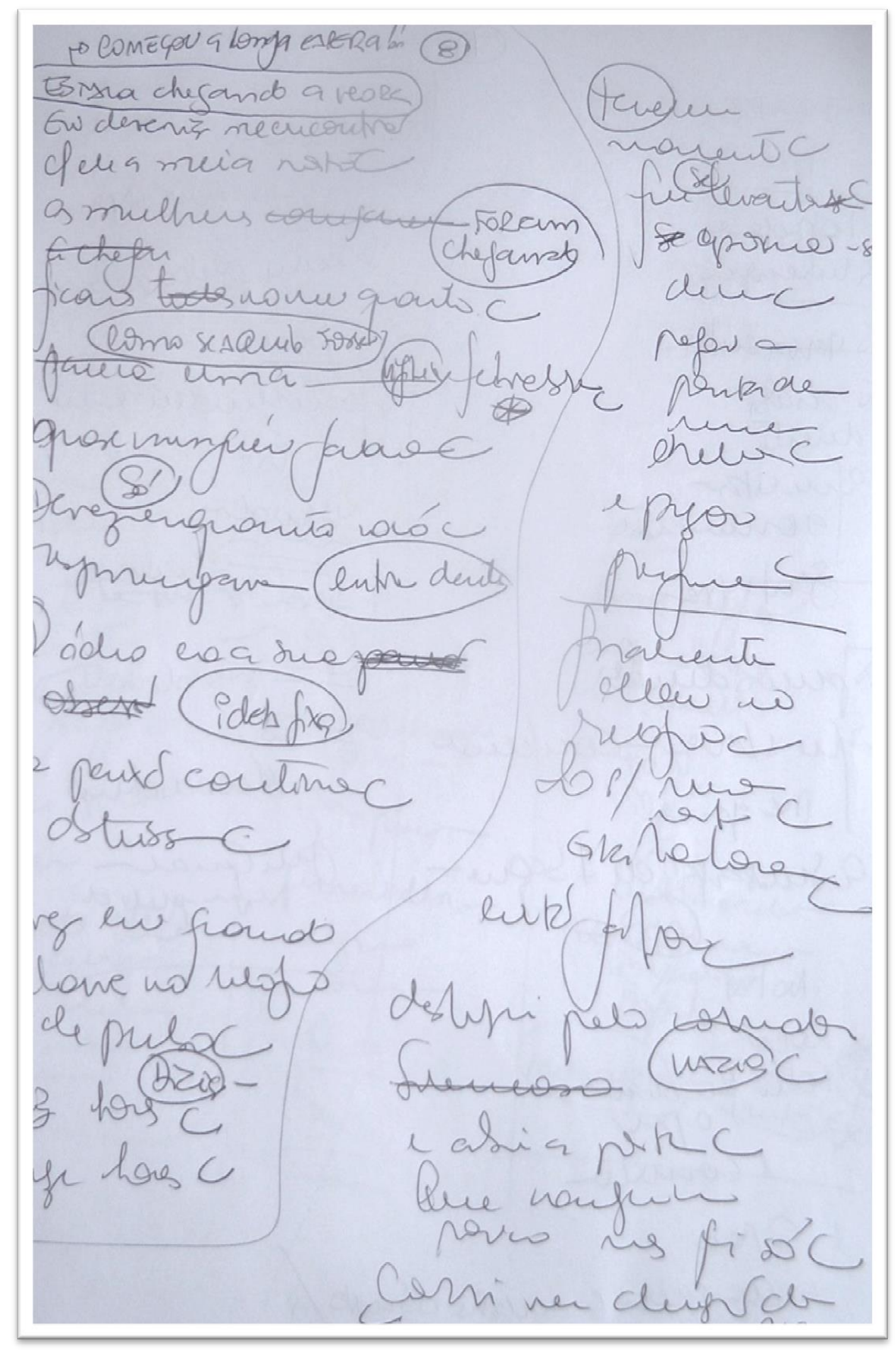

Figura 27: Manuscrito que passou pela repetição até a memorização 


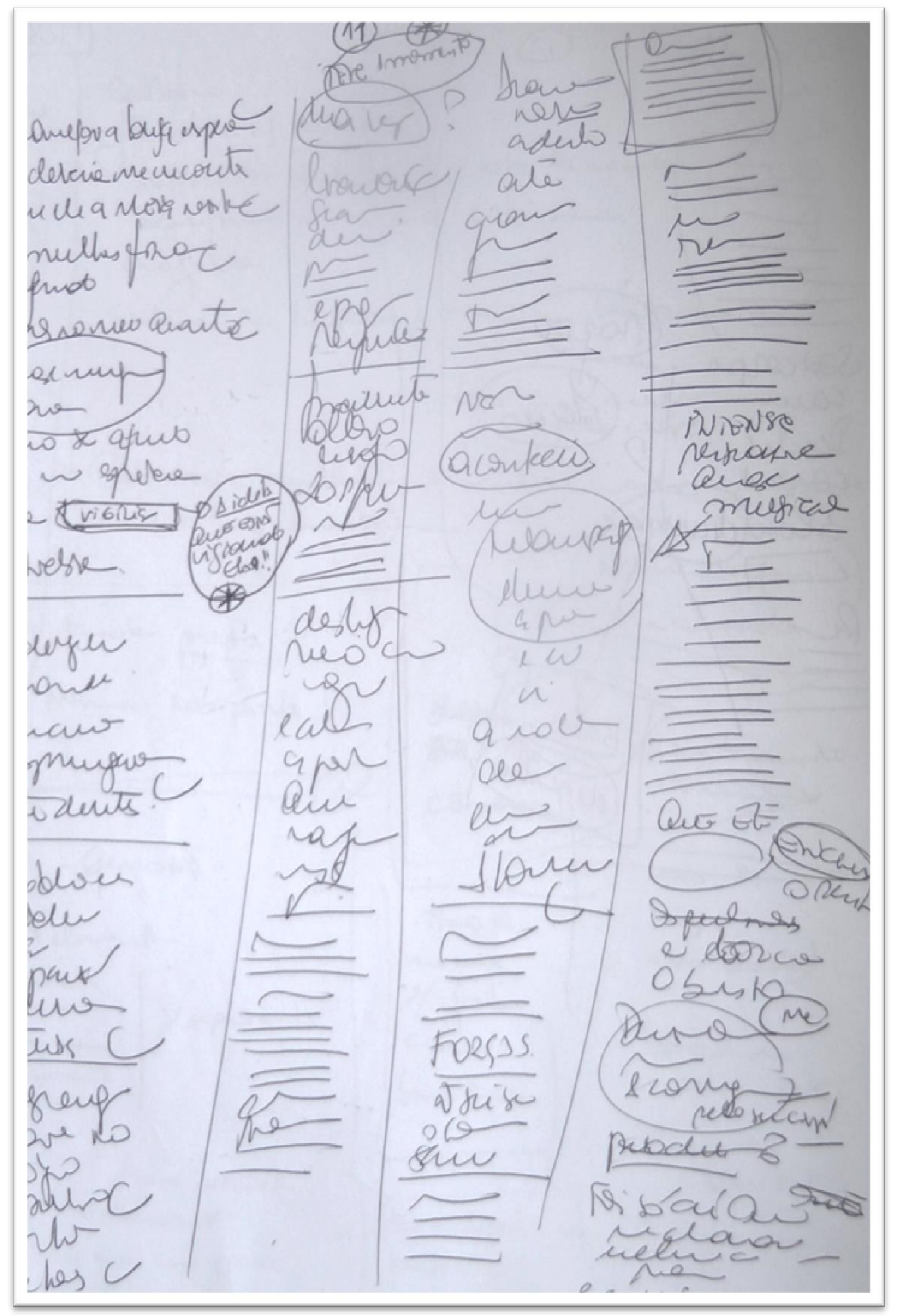

Figura 28: Manuscrito que passou pela repetição até a memorização 

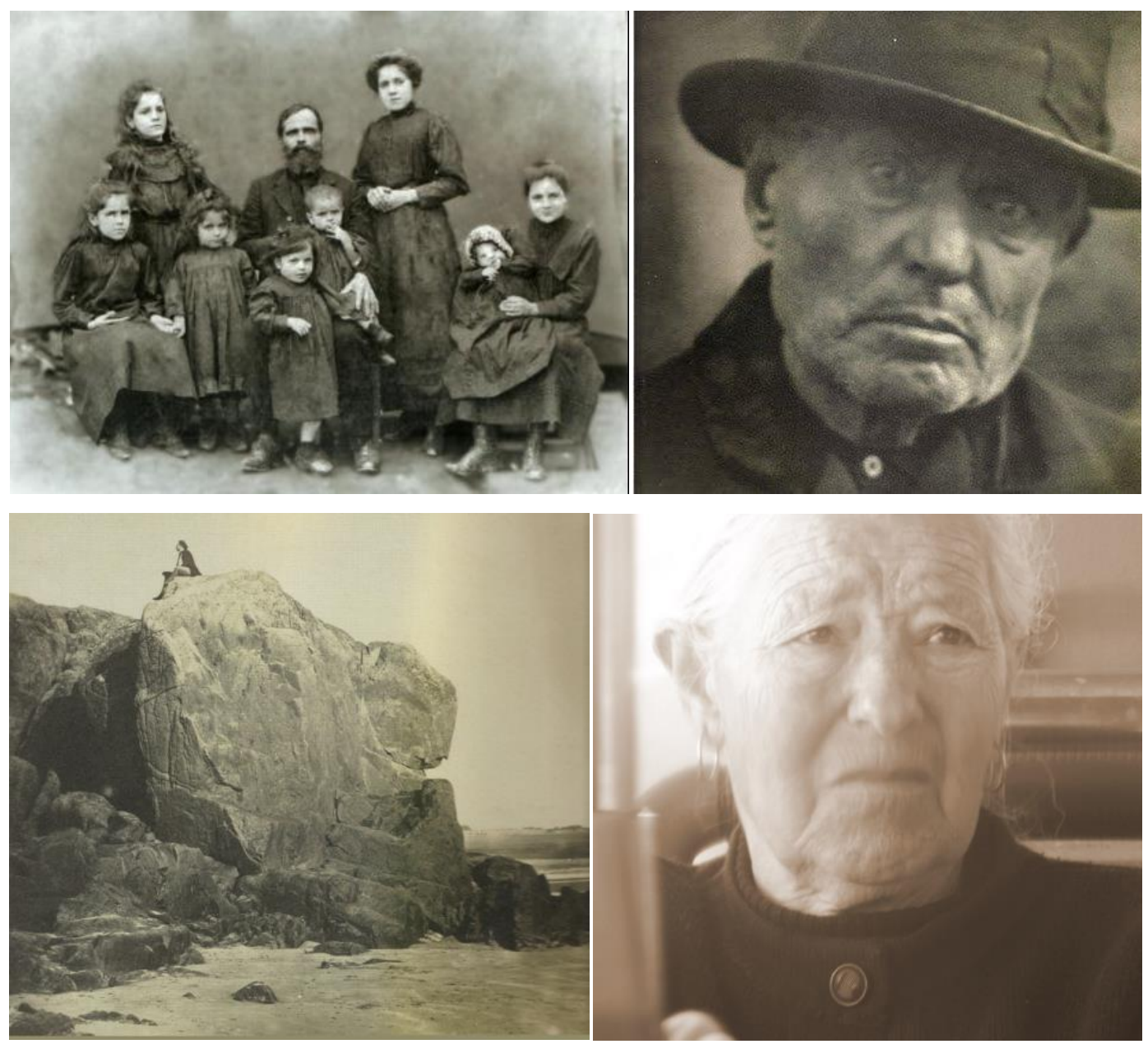

Figura 29: Fotografias Projetadas em "Casa"

\subsubsection{Tensões e Olhar: "A Fuga"}

Posiciono a câmera no tripé em meio à alameda do cemitério da Rua Cardeal Arco Verde. Procuro um pedaço de pedra, me agacho diante de uma lápide e escrevo no chão: "Mamãe você é uma santa". A cena em que a menina visita o túmulo dos pais é reduzida a uma frase e deslocada do seu lugar no romance rodrigueano. A posteriori, suscita uma fantasia: um pedido de perdão à mãe. Apresento o arranjo externo e minha improvisação (com os impulsos do pré-jogo) no CEPECA aos demais pesquisadores. Mas, no vídeo projetado, eles não conseguem ler a frase. Coloco a caligrafia no vídeo; a mesma frase sobreposta na projeção. 


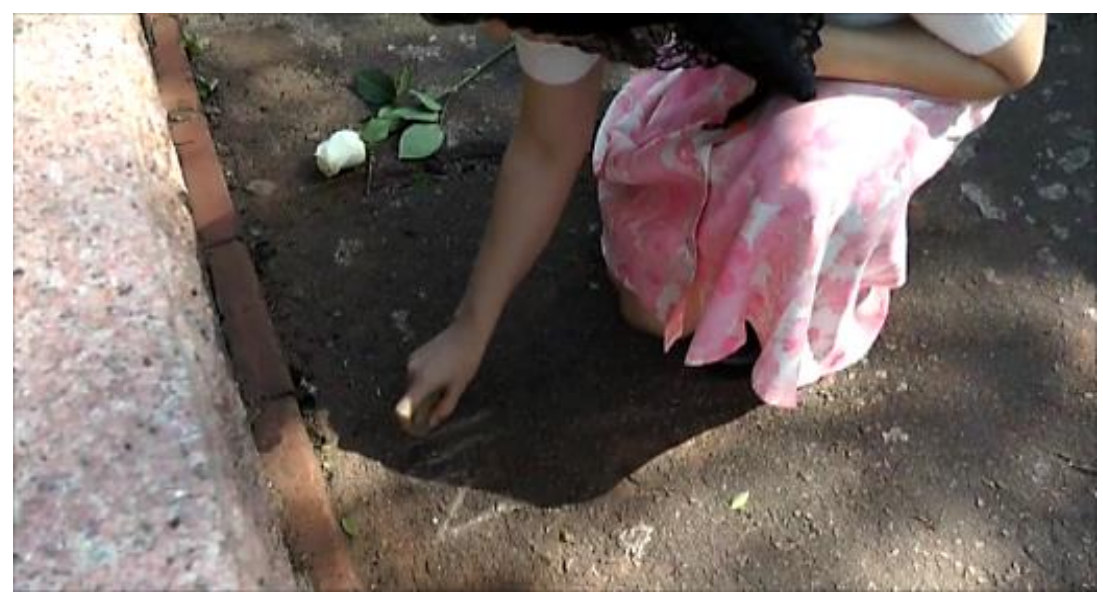

Figura 30:

"Mamãe, você é uma santa"

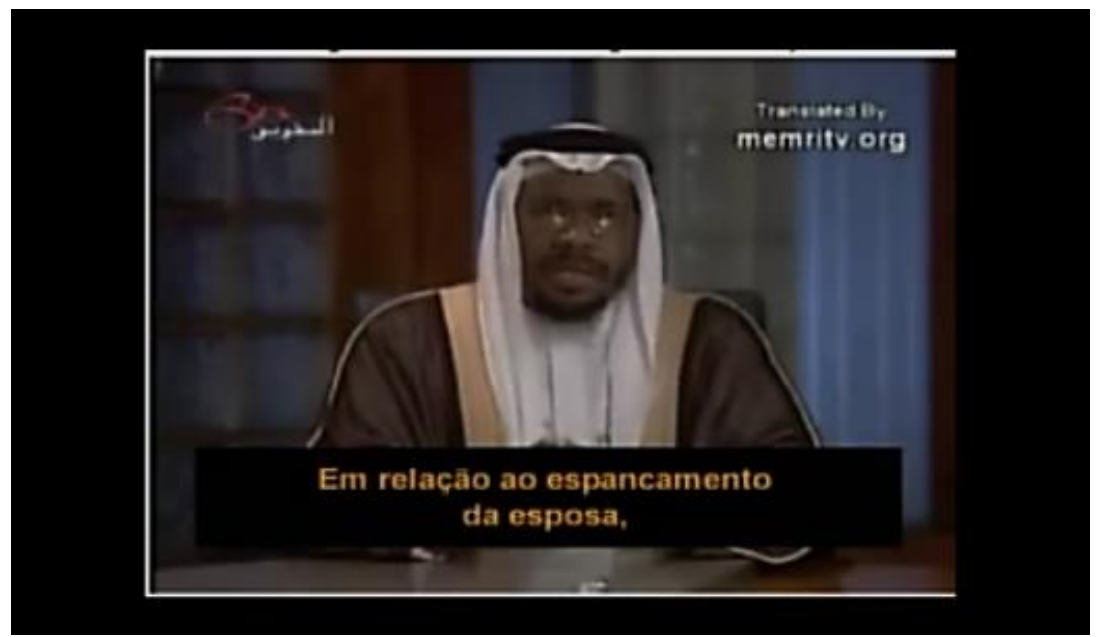

Figura 31:

TV do Behrein: Aula sobre como surrar a esposa ${ }^{19}$

O vídeo do cemitério entra logo depois de outro: um líder religioso ensinando aos homens como devem bater na sua esposa. Aparece um debate sobre a posição da mulher na partilha do desejo (e o seu não acolhimento no âmbito social); uma crítica à ordem institucionalizada, que atribui à surra o estatuto de lei (não aos homens violentos que batem às escondidas, mas aos que obedecem à ordem estabelecida, que é surrar). Escolhi o vídeo porque há algo na visualidade da obra rodrigueana, inscrito na cultura e em diversas citações, que é: “a mulher que gosta de apanhar”. Quis mostrar o avesso. Sento para assistir, me inscrevendo em cena junto às diversas bonecas que estão em pé multiplicadas no cenário. Odeio-as por serem mulheres. Arranco a cabeça de uma por uma, imaginando que são aquelas bailarinas que, nas aulas de ballet, tinham os pés com curvatura e uma articulação da virilha en-dehors, enquanto eu sonhava com a forma que mudaria meu corpo, pensando que, se tivesse nascido na Rússia (e treinado desde os três anos), ele seguiria as normas estéticas do ballet. Este é um anteparo oculto, empilhado.

19 Disponível em; http://midiaarabe.blogspot.com.br/2007/11/aulas-de-violncia-contra-mulher-via.html Acesso em 08/01/2014. 
Os vídeos entram depois de a família da menina ser raptada e a protagonista presa pelo tio de criação. No CEPECA me dizem que não entendem a história. Desejosa de que a sua visualidade seja evocada, narro passagens. Utilizo vozes sonorizadas - com uma sonoridade típica dos coros de vizinhos rodrigueanos. Lembro-me dos coros das encenações do Marco António Braz. Tenho esta sonoridade nos ouvidos. Quando as vozes entram em cena, eu faço o seu corpo. Ainda preciso de mais anteparos. Mas é a relação entre a anunciação da novidade e a surpresa que conta neste momento.

\begin{abstract}
Abandonaram a casa!! Foi o tio quem os levou!!! Aristeu ama a menina!! Mas Santo Deus!!! E o noivo? Encarcerado!!! Quem?!! Jorge!!! O amante da mãe?!! Ninguém sabe!!! Fala-se muito!! Está que morre ou não morre!!! A avó, pressionada, assinou os papéis!! A sobrinha fica com o tio!! Valeime Deus!!! E o casamento?!! Sem padre, sem juiz, nada!! Uma farsa!!! A avó está endemoniada!!! Subornou um empregado para que tire todos de lá!! Em troca, a menina será gentil com ele!! Entregou um bilhete!! Em nome dela, da menina!!! Marcou o encontro!! Céus!!! Atrás da pedra, a meia-noite! E ela vai? Levou uma bofetada! Diz que vai! Mas Aristeu diz que mata!!! Ele mata!!!
\end{abstract}

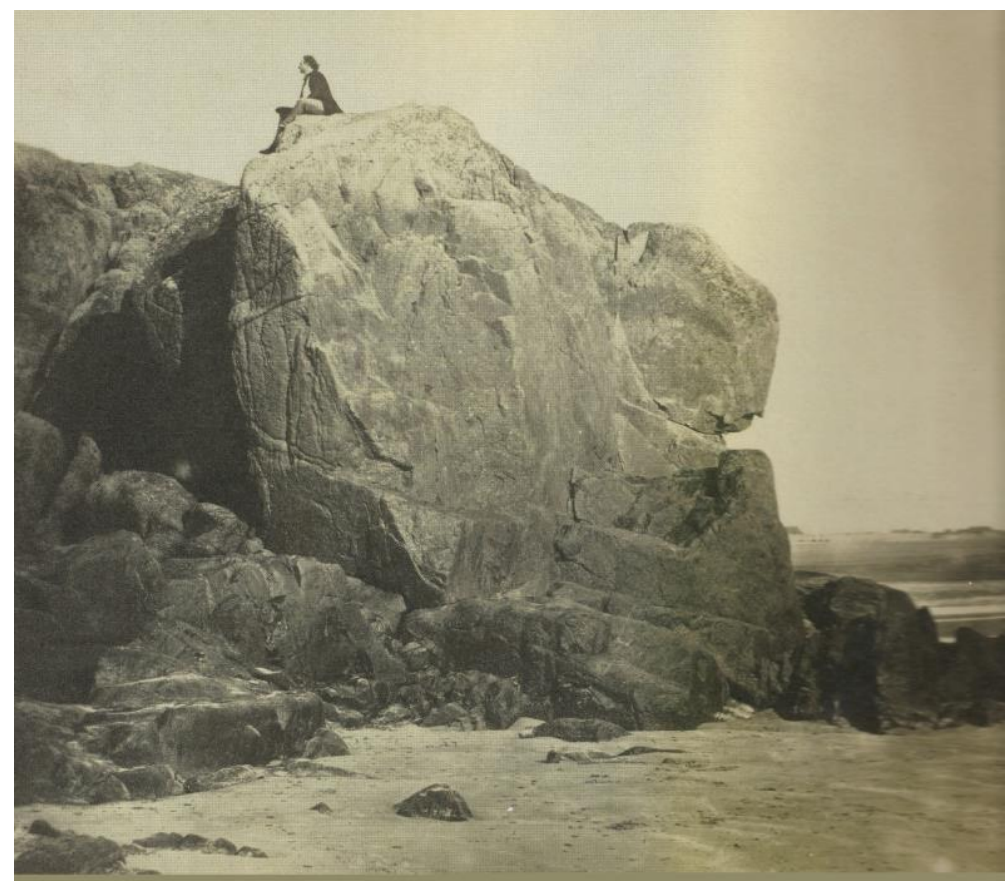

Figura 32:

O Encontro na Pedra.

A menina encontra-se dividida entre a lei da avó (que ordena que se ofereça a um desconhecido para que ajude a família a fugir) e a lei do Tio Aristeu, que quer casarse com ela e que a mata se ela o trair. Segue a música do Kieslowski e entra a fotografia de um homem sentado em uma pedra enorme. A fala é anunciada no microfone: 
Eu deveria me encontrar com ele à meia-noite. As mulheres foram chegando. Ficamos no quarto, como se aquilo fosse uma vigília fúnebre. Só de vez em quando vovó resmungava entre dentes. O ódio era a sua ideia fixa, a sua paixão contínua. De vez em quando, ela olhava o relógio de pulso: - Nove horas - Dez horas - Onze horas. Teve um momento em que se levantou. Aproximou-se de mim, pegou a ponta da minha orelha e pingou perfume. Finalmente olhou no relógio: - Vinte para a meia-noite! Deslizei pelo corredor vazio e abri a porta que dava para a praia. Rangeu um pouco, mas foi só. Corri na direção do mar ouvindo gritos humanos atrás de mim numa espécie de delírio provocado pelo vento. Avancei noite adentro até a completa incapacidade de dar mais um passo. Neste momento um relâmpago iluminou tudo e vi a rocha do encontro. Dentro da luz estava um homem. Minha ideia foi chamar, mas não saiu som! Quando voltei a mim, ele estava na minha frente. Afastava os cabelos caídos da minha testa e tirava a areia do meu rosto. Nascia em mim um reconhecimento doce. Precisava dizer: Quero que você me leve daqui! Toda a minha família! Sua voz era persuasiva, musical. Tudo aconteceu de uma maneira imprevista, rápida e silenciosa. Não entendi direito o que estava acontecendo. Tive apenas a noção de um baque. Notei que ele enchia o peito e revirava o busto. Me deixou escorregar vagarosamente pelo seu corpo. Só aí um relâmpago encheu o céu e eu vi, no seu olhar, uma expressão de interrogação - como se enxergasse, não o meu rosto, mas a máscara da morte. O corpo caiu como um bloco de chumbo.... Senti que alguém respirava perto de mim.

Isto me estimula: a imagem de uma avó sem escrúpulos. A fala externa evoca imagens que estão ocultas. Um corredor, a praia, o cansaço, a tempestade, o homem, a gratidão, o gesto, o assassinato, o homem parando de respirar: visualização evocada com as palavras. Mas o espectador não entende isto. Apesar de narrar o trecho inteiro, o seu olhar se perde por outros materiais da encenação (é o testemunho dos pesquisadores no CEPECA). Grafo algumas frases da narrativa na projeção. Mais grafia em cena. Uma visualidade descolada do corpo. Para o desenho corporal tenho uma "dancinha infantil quase erótica" extraída do filme "Cria Cuervos" (Carlos Saura, 1974). Não fixei os movimentos, mas a imagem das três irmãs dançando no quarto está no arranjo e é um material para o improviso enquanto as fala das palavras externas "puxam" o corpo para outros movimentos: a boca, com alternâncias entre as consoantes e as vogais (diferentes desenhos se alternam). Encarnada, a imagem da dança se transforma junto à música da banda inglesa "The Puppine Sisters". O microfone limita os movimentos do braço. E também espalha a voz no ar, que retorna sobre mim - formando uma espessura, camada no espaço. Estes materiais, juntos, criam uma tensão; o foco desliza entre eles, buscando desenhar, no olhar, o que está sendo produzido com o corpo. "Dancinha quase erótica": minha melhor amiga e eu, com sete anos nos exibíamos na sala de casa dançando para os adultos. Imagino um cabaré. Vem aos olhos uma peça do Plínio Marcos montada com a Valderez de Barros (que fazia a dona do bordel): "Querô", dirigida pelo Eduardo 
Tolentino em 1993. A casa noturna com aquelas músicas e luzinhas; o universo brega do vômito; a perda de limites - bem perto da morte.

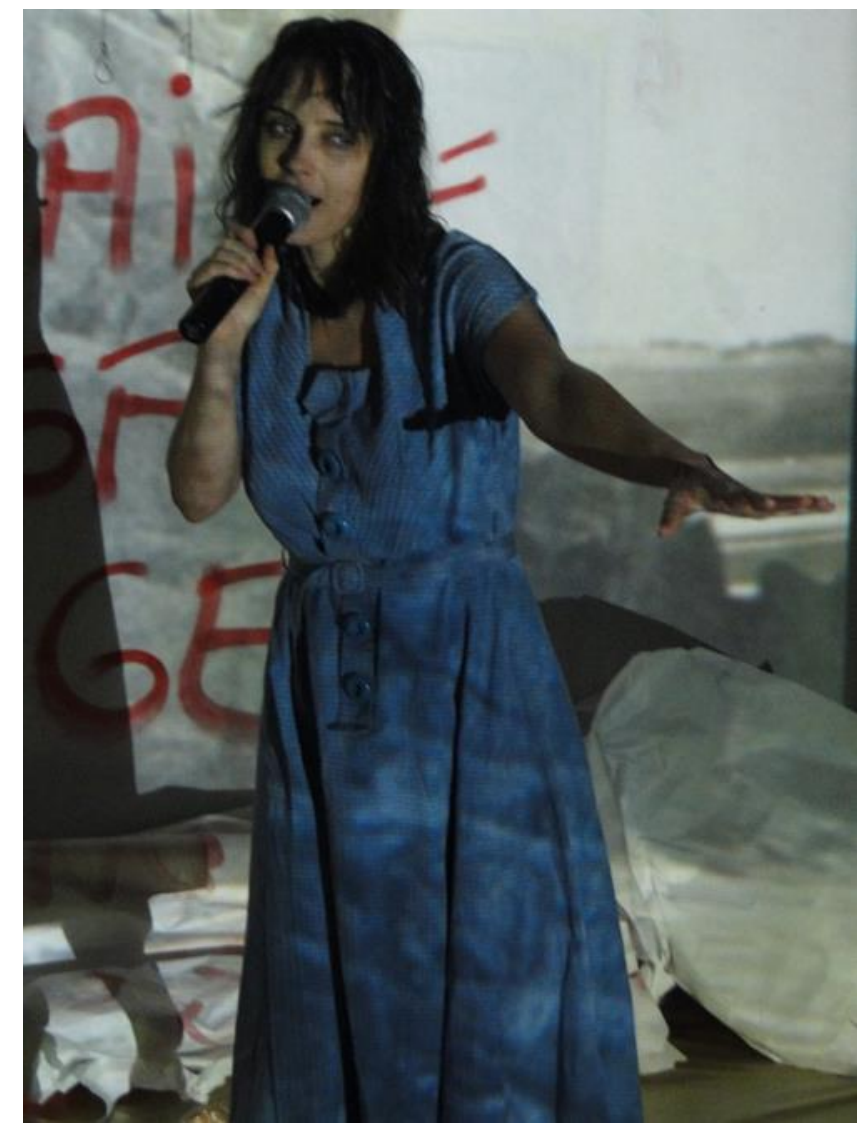

Figura 34: Foto de Cena: "Dancinha infantil quase erótica".

Uma cena poluída. As palavras evocam uma visualidade inteiriça do universo ficcional. Trabalhei-as repetidas vezes, com a repetição do pré-jogo, na escrita, para densifica-las. Mas a atenção do espectador vai para outros materiais. Conforme o testemunho dos pesquisadores do CEPECA, eles também dividem o foco. Em ateliês dramáticos sinto a mesma tensão. Muitas vezes retiro a projeção e as músicas, para que, da atuação e palavras, as relações (com pensamentos, contradições, relações, conflitos) sejam evocadas, inscrevendo seres humanos viventes. Mas em "Casa" a opção foi investir no choque, no contraste, poluição. Coloco as grafias nas projeções: algumas frases-chave para que a visualidade do enredo não se perca. Espero que eles leiam, mas não sei se, em outras imagens se perdem, inclusive as do corpo. 


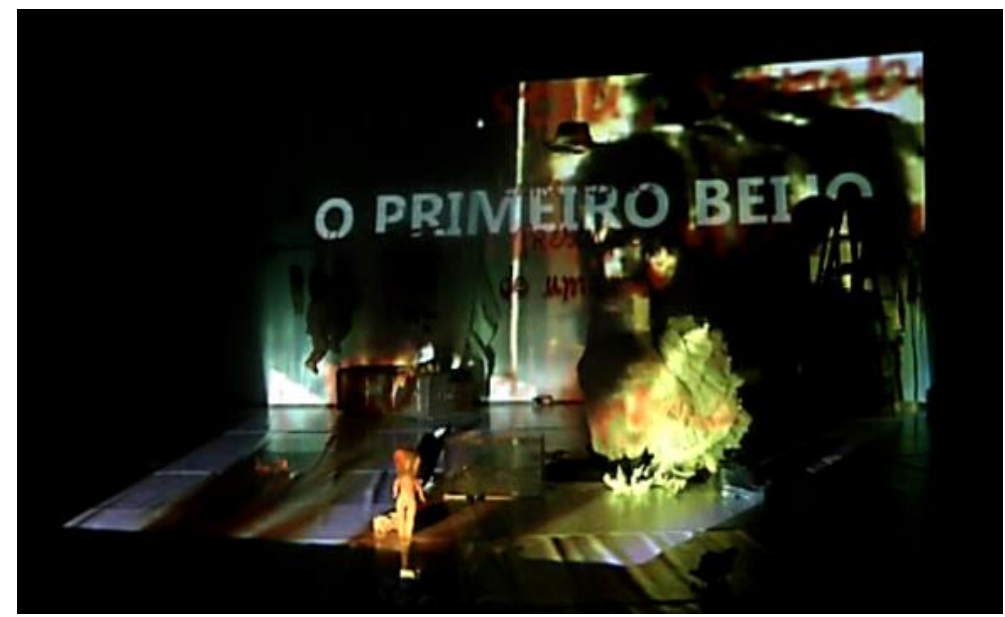

Figura 34:

Foto de Cena:

"O Primeiro Beijo"

A tensão entre plasticidade e enredo é clássica não apenas na história do teatro, mas do cinema. Enquanto Griffith privilegiava a narrativa, as vanguardas francesas dos Anos 20 (Epstein, Dulac de Luc), influenciadas pelas artes plásticas, faziam oposição ao elemento narrativo e privilegiavam a plasticidade dos quadros. É em meio a esta tensão que o ateliê se desenvolve, cada cena com resoluções diferentes. Opto pelo enredo. Mas este é material isolável, posto em relação com outros. O texto rodrigueano é campo de extração para dez situações, que entram nos arranjos: A Morte dos Pais, Os Cuidados da Avó, Os Dois Pretendentes, O Primeiro Beijo, O Plano, A Viagem, A Prisão, A Fuga, A Vingança, A Liberdade - entre os vinte e sete capítulos do romance - cuja nomeação implica um recorte. Estes títulos são projetados para introduzir as cenas. A associação de projetar os títulos (recurso épico), veio das legendas de "Ondas do Destino", filme de Lars Von Trier (1996).

\subsubsection{O Que Estranha?}

O desenho externo com objetos, projeções e músicas podem estranhar, assim como as figuras extraídas das artes plásticas que, quando incorporadas, organizam o desenho do corpo, delimitando a sua tessitura no espaço. Pina Bausch (coreografa alemã tomada como uma das representantes do teatro pós-dramático ou teatro performativo) e Edward Munch (representante da pintura expressionista) suscitam associações. 


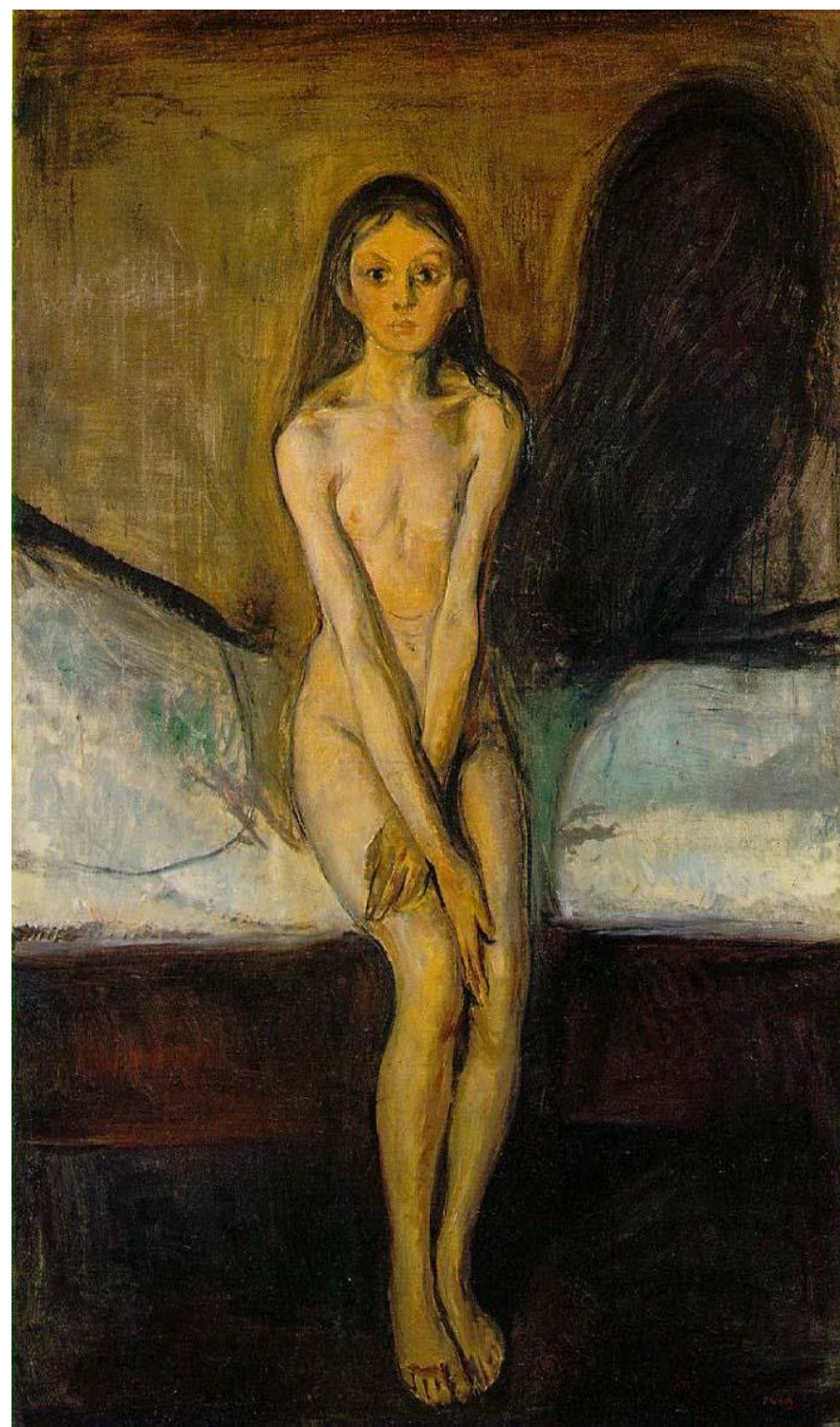

Figura 35:

Puberdade

(Munch, 1895)

A pintura expressionista articula um imaginário sobre a morte. Ela entrou no arranjo de "Casa" a partir da associação de Evinha Sampaio ao se deparar com minha improvisação com um pré-jogo que ainda estava bem distante do que hoje se configura: era praticamente o texto rodrigueano (memorizado) e exposto em cena. Deparar-se com o corpo da mãe morta (imagem oculta) já fazia incidência e eu me deixava levar pelas palavras, ações evocadas e impulsos impregnados durante as repetidas escritas do préjogo. No entanto, não havia uma poética da cena. A plasticidade corporal trabalhada por anteparos das artes plásticas ajuda a evocar ações ao mesmo tempo em que constrói uma poética para o corpo. A invasão das palavras (e imagens internas) na tessitura corporal precisa de limites; ser enquadrada em uma poética, desenhada. Assim, a forma corporal 
passa a evocar um verbo-de-ação ${ }^{20}$, mas com uma plasticidade que é cênica. Tal como as grafias nas projeções, ela está para além desta ação que evoca (tal como a escada): ela é grafia também; é coreografia.

Posso também trabalhar um jogo de deslocamentos do olhar: a plasticidade do olhar da narradora entra em jogo e é também uma modalidade de enquadramento. Para dentro e para fora da situação vivida. Também pode estranhar; poetizar. Mas é preciso construir estes deslocamentos, colocando, na fala interna, significantes: como “jornalística", por exemplo. "Jornalística" traz outra voz e evoca outra ação, produzindo uma distância do fato narrado (ao contrário do apossamento, no corpo, pelas palavras externas que narram aquela visualidade do passado da menina). É outra cadeia; de ações paralelas ao fato narrado.

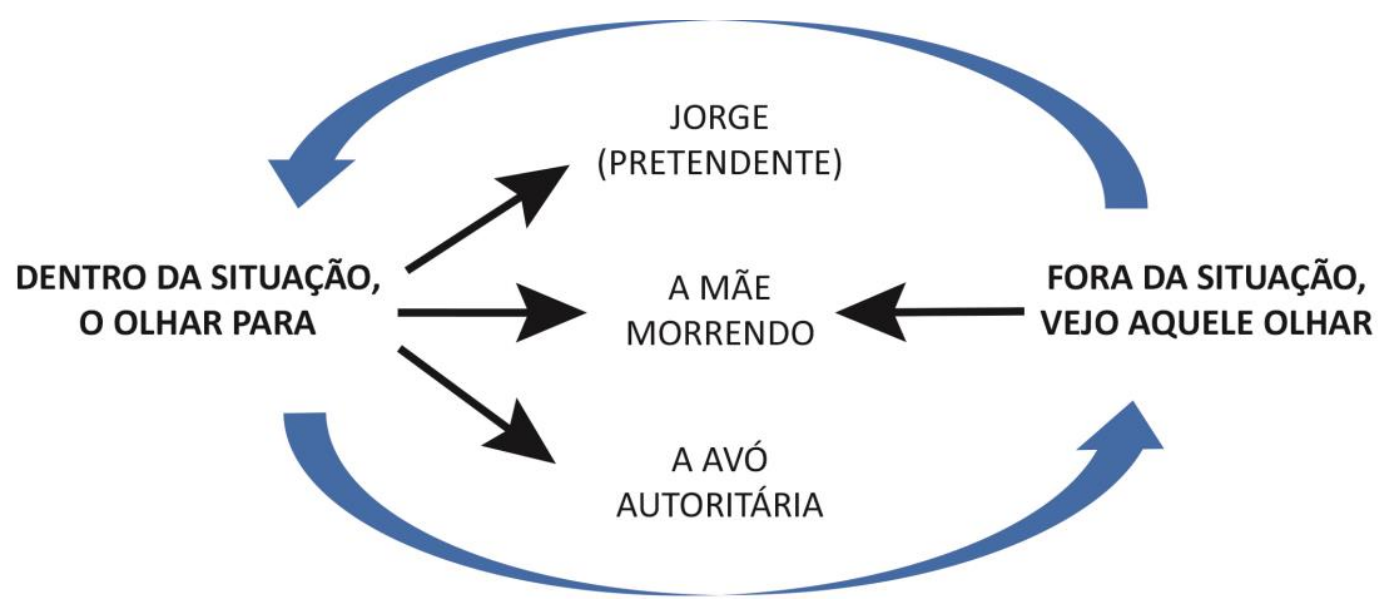

Figura 36: Deslocamentos do Olhar
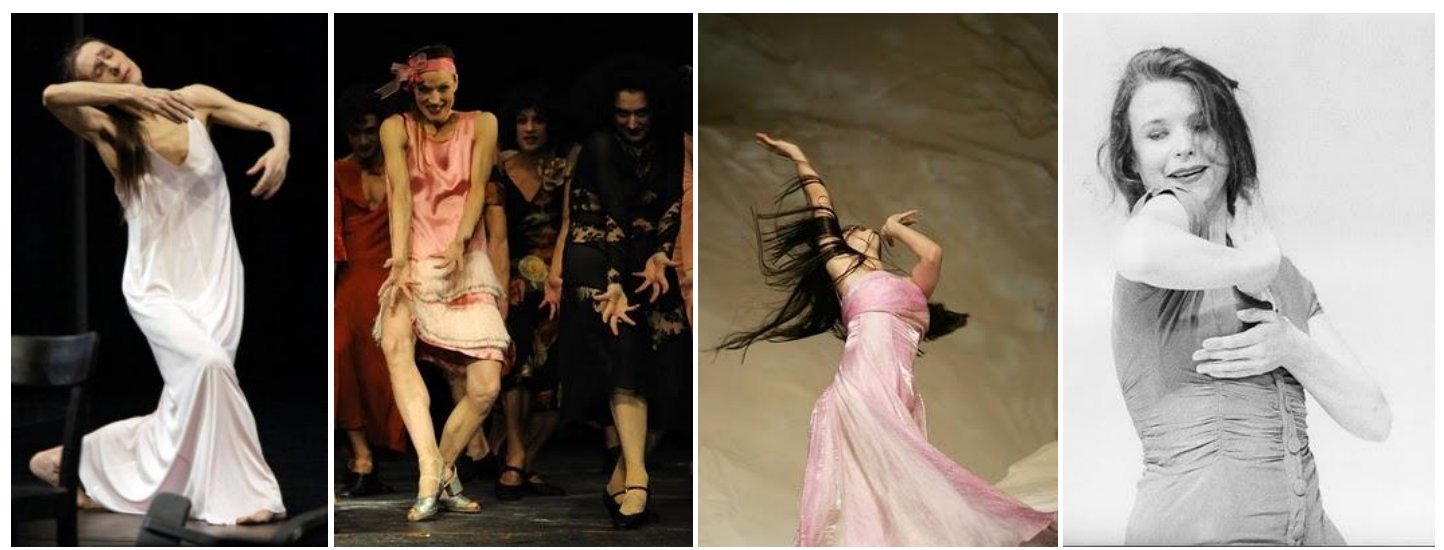

Figura 37: Anteparos Extraídos de Espetáculos de Pina Bausch: Café Müller (1978); Os Sete Pecados Capitais (1976); Rough Cut (2005); Walzer (1982)

${ }^{20} \mathrm{O}$ "verbo-de-ação" é um verbo que expressa ação. Na Análise Ativa, Stanislavski divide o texto dramático em pedaços menores e introduz verbos-de-ação nas suas entrelinhas para provocar ações. 
A plasticidade corporal ou dos objetos se inscreve no imaginário da ficção, mas não totalmente - resta uma parte de fora. Uma cadeira virada para conversar com o pretendente não tem razão de ser na ficção a não ser que se produza a posteriori: “o mundo de Suzana está virado". Trata-se de um diálogo com a cena de Pina Bausch (uma pulsão de encenar a incidência daquela imagem sobre mim); um enquadramento que diz respeito ao "eixo extra-ficcional" - e que sai fora, subverte, imprimindo uma poética.

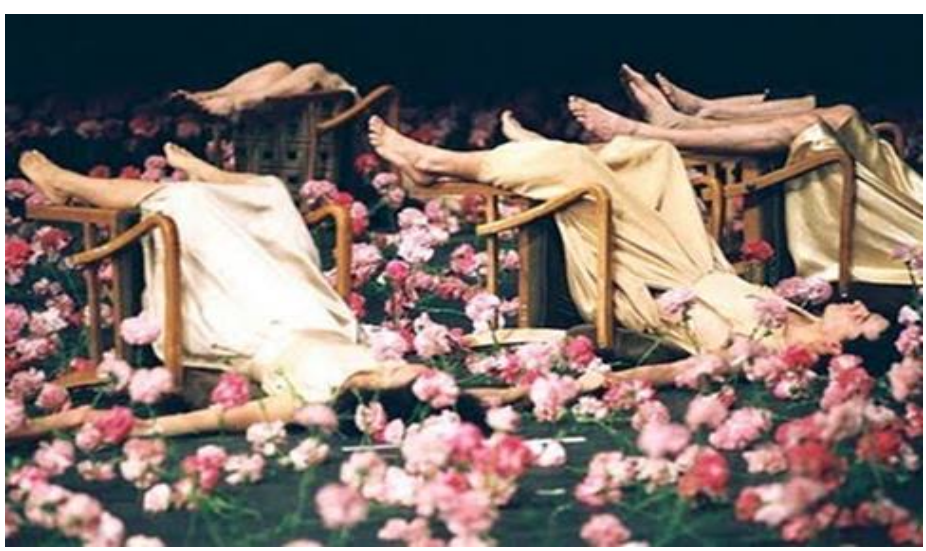

Figura 38: Walzer (Pina Bausch, 1982)

A noção de eixo extra-ficcional encontro no trabalho do Prof. Dr. Stephan Baumgartel $^{21}$ :

\begin{abstract}
A tarefa estética especificamente contemporânea, tanto no âmbito da dramaturgia quanto da encenação, consiste em achar formas de incluir explicitamente essas preocupações na estrutura do texto teatral e espetacular, e não somente mantê-las implícitas. Aceitar essa tarefa claramente fortalece o eixo da comunicação extra-ficcional, entre palco e platéia, em detrimento do eixo intra-ficcional entre os personagens. Estratégias contemporâneas que respondem a este desafio são na sua essência anedóticas e podem ser chamadas pós-dramáticas, pois eles rompem com a dominância do signo referencial e figurativo da estética dramática. Seus signos não afirmam um discurso homogêneo, mas sustentam na sua materialidade valores mais expressivos e performáticos do que representacionais (BAUMGARTEL, 2008, p. 04)
\end{abstract}

A experiência estética advinda de corpos "estranhados" em espetáculos de Pina Bausch e Tadeusz Kantor incide tanto quanto a cotidianidade suja e o despojamento das ações inscritas no cotidiano diegético e mimético no cinema. Mas o arranjo com a fala externa de "Minha Vida", romance rodrigueano, me conduz a uma exacerbação: o corpo carregado da incidência daquelas palavras, evocando uma situação melodramática. Ao

${ }^{21}$ Professor do curso de Artes Cênicas na Universidade Estadual de Santa Catarina. Ver: BAUMGARTEL, S. A peça histórica no âmbito das formas teatrais não-dramáticas. Fênix (UFU. Online), v. 5, p. 04,2008 
mesmo tempo, anteparos das artes plásticas e do teatro performativo tendem à poética do desenho, de uma forma estranhada, do movimento - de maneira que não consegui inscrever o contexto cotidiano da narradora em cena. Tentei, mas não consegui. Com a ideia de formar os arranjos com objetos, sons, imagens, movimentos e palavras a um só tempo expostos, a cena tende à abstração: os objetos são pendurados (chapéus, vestido) e transformados em outras coisas (aquário e escada são homens); associações-livres (o varal com bonecas vendadas) fora do enquadramento ficcional. A proposição de expor anteparos acaba por evocar uma visualidade de um espaço subjetivo (uma "casa") cujos fragmentos ajudam a narradora a reconstituir a história - mas uma história que não se afirma quanto tal; escapa apesar da sensação de ter uma fábula ser boa. Internamente, a imagética se constitui sobre a ficção - por associação com a "minha" vida (da Rejane). Associações envolvem cadeias significantes: a adolescência, primeiros relacionamentos. O enredo rodrigueano se comporta às vezes como o elemento-pivô, operador lógico de cortes (o que gera tensão quando as associações não se enquadram). Apesar de não estar inscrita na fabula, uma cadeira virada de Bausch, através de uma interpretação, pode, $a$ posteriori, articula-la. Mas, para muitos materiais eu não consigo encontrar um lugar no discurso sobre a ficção. Quero encená-los, mas não sei como. Ficam à espera de um encontro a posteriori ou o trabalho pende para a abstração; a diluição da visualidade da situação. Há tensão entre uma plasticidade dos materiais (aquário, água, escada, chapéu pendurado, coro de trinta bonequinhas, mala, varal de arame farpado) e o enredo.

\subsubsection{Associações Impertinentes (ou A Determinação da Associação): "O Primeiro Beijo"}

Um blog foi proposto como um procedimento metodológico. Os relatos são documentados durante a criação e auxiliam a posteriori o pesquisador a depositar um olhar crítico sobre os momentos de envolvimento: "As imagens se reaconchegaram na função do olhar. Agora é Jorge quem deita. O chapéu encostado no aquário. Uma orelha. O sapato de homem. Eu cochicho as frases e ele me beija. O paletó me abraçando": um jogo da visualidade da cena e o olhar da atriz através de associações no cotidiano, acordando, atravessando a rua, tomando banho, indo dormir. As imagens invadem o olhar. A narrativa enlaça as memórias: "Eu não suportaria ver o Augusto chorar” penso - e a frase entra no pré-jogo. “(Eu não suportaria ver o Augusto chorar) 
Jorge eu me caso com você, mas quero que saiba: vou traí-lo. Serve assim?”. A fala interna apoia, marca, faz um vinco outro, diferente do texto externo (que é um material de enquadramento). Ela enlaça a tessitura da minha memória corporal (que precisa ser enquadrada pela fala externa). Esta fala interna não situa uma ação propriamente, mas um lugar. Apesar de indicar a tristeza e a culpa, há também incidência da fala externa e do imaginário da ficção: enquadramentos, que entram em jogo (pois incidem também). Em cena a resultante não é tristeza ou culpa, mas: deboche, ironia. Uma marca que está no arranjo se desdobra, dá passagem para um novo material (a cadeia se desdobra), os arranjos se desdobram em uma resultante. Há defasagem, produção nova.

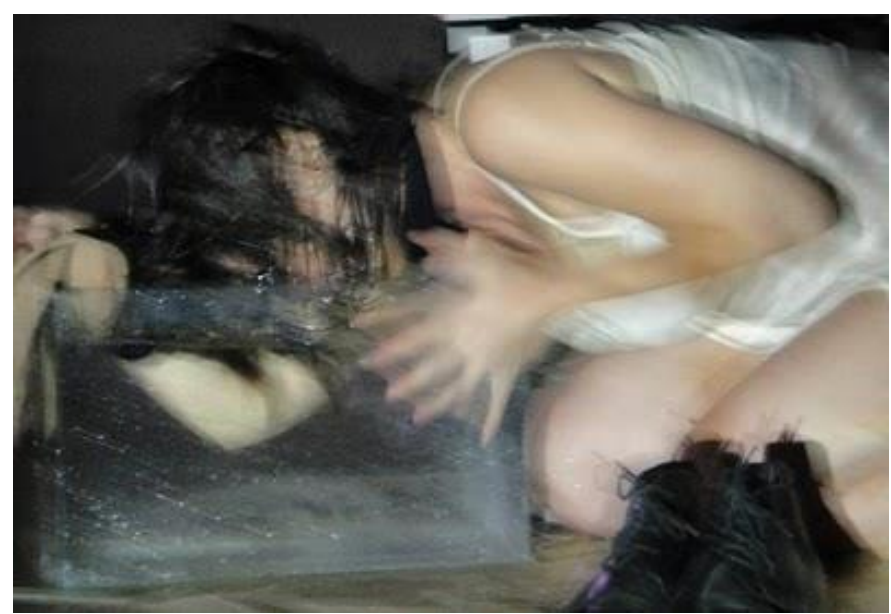

Figura 39: Foto de Cena: O Beijo no Aquário

Uma fala de alguém no CEPECA reverbera nos ouvidos (fazendo incidência) no meio da rua durante a semana. No blog está: "Veio de um estalo a partir da frase da Cris 'pensei que era um sapato de homem'”. Christiane Lopes confundiu o sapato (de boneca) que estava em cena com um sapato de homem. Coloco um sapato masculino no aquário e surge um enquadre ficcional: de sapatos e chapéu o aquário é Jorge. "Acordei hoje de manhã com isso. Grudou em mim”. As frases grudam, atravessam os ouvidos; as imagens incidem, aparecem no olhar; deslocam-se por entre os arranjos e juntam-se com outras, provocando nova configuração imaginária, plástica.

\footnotetext{
Os atores às vezes falam do antes, do que pensamos, do que combinamos, do que "intencionalizamos" para a cena, como algo da ordem do racional. Mas o que há de racional em imagens que me invadem quando acordo? Quando "acorpo" eu ia dizer... Há uma "fazedura" dramatúrgica da encenação que é "o antes" e é extremamente intuitiva, se devo dizer assim. O que entra em questão é como transformá-la em impulso, como fixar a sua incidência. ${ }^{22}$
}

${ }_{22}$ Blog "O Ateliê de A Casa de Suzana": $\underline{\text { http://rejanecepeca.blogspot.com.br/?zx=c38b6ed16236cfee }}$ 
Mas materiais precisam ser cortados: no diálogo com colaboradores, cultura e na escrita. Posso rememorar a cena e cortar criando uma nova colagem. Parece haver a insistência de alguns materiais - que retornam. Até que algo se organize, eles trocam de lugar e se juntam em novas formas: empilhamentos e deslocamentos. Até a erupção de uma imagem "que fica" (que se torna escrita cênica), imagens diferentes em fluxo como bombardeio, tempestade. Não vejo com o "olho" (o órgão), mas com o olhar (como função): algo que não está na realidade objetiva pode ser olhado (a plasticidade das associações que, juntas, criam uma cena)

\begin{abstract}
Os cortes que exercito na função do diálogo com a Evinha eu também exercito no meu exercício dramatúrgico solitário. O que acontece é que vou limpando, limpando, tirando, tirando, até chegar a algumas imagens que assumem um valor impressionante, que me causam; causam o meu desejo de ir à cena encená-las. Passo por uma série de desconfianças. Em um momento a intuição impera e eu chego a elas; mas em seguida elas se desgastam em mim e perdem valor. Mas, na medida em que vou limpando as palavras, varrendo-as, chego a certas imagens imperativas. Que ficam. Talvez possa fazer a analogia, aqui, com o que o Miller (Jacques-Alain Miller) chama de "a ponta imaginária do simbólico"? ${ }^{23}$ O que percebo é uma espécie de enquadramento. Uma espécie de condensação, de densidade conquistada. Isso se prolonga na imaginação. Depois do exercício dramatúrgico de cortes, eu durmo e acordo. E sonho. Acordada também. Como uma espécie de devaneio, a imagem se densifica; se grava; se agrava. No olho interno. A função do olhar está toda aqui. E da rememoração. E da invenção, porque estas imagens não existem. Estão sendo criadas via um manejo. Via jogo de linguagem se chega nelas. Hoje de manhã acordei com a imagem da avó fazendo carinho no chapéu de Jorge. Então me restaram - estas imagens são um resto, a ponta de todo o jogo dos significantes que vivenciei e esta é uma vivência, uma experiência subjetiva (21/08/2011).
\end{abstract}

Como um escultor retira argila para fazer aparecer escultura. Como ilustra

Graciliano Ramos, o escritor tem que "secar as palavras", feito uma lavadeira.

\begin{abstract}
Deve-se escrever da mesma maneira como as lavadeiras lá de Alagoas fazem seu ofício. Elas começam com uma primeira lavada, molham a roupa suja na beira da lagoa ou do riacho, torcem o pano, molham-no novamente, voltam a torcer. Colocam o anil, ensaboam e torcem uma, duas vezes. Depois enxáguam, dão mais uma molhada, agora jogando a água com a mão. Batem o pano na laje ou na pedra limpa, e dão mais uma torcida e mais outra, torcem até não pingar do pano uma só gota. Somente depois de feito tudo isso é que elas dependuram a roupa lavada na corda ou no varal, para secar. Pois quem se mete a escrever devia fazer a mesma coisa. A palavra não foi feita para enfeitar, brilhar como ouro falso; a palavra foi feita para dizer (Ramos, 2005) ${ }^{24}$
\end{abstract}

23 Ou "a projeção do simbólico sobre o eixo imaginário" (MILLER, 1997, p. 509)

24 Disponível no site oficial de Graciliano Ramos: http://graciliano.com.br/site/obra/linhas-tortas-1962/ Acesso em 08/01/2014. 
Mesmo que dela não se extraia um dito comum, é preciso provocar escuta. Cada um escuta do seu desejo. Mas há dizer. A associação com o aquário passou por deslocamentos. Imaginei primeiro um aquário imenso comigo dentro d'água, sentada em uma cadeira, uma boneca no colo e um barbante nos dedos; suspenso no ar, um chapéu masculino como se fosse um balão a gás. O aquário reduziu de tamanho e a água foi associada ao "beijo molhado" de Jorge. Materiais imperceptíveis sustentam uma incidência interna cujos efeitos de reverberação são enquadrados pelo arranjo externo. As falas internas estão em itálico:

(Formiga) Não, por favor, Jorge, eu não quero!! (Fica fraca e cai. A boca na água e... formiga) Por favor não! Eu não quero! Até que (fica fraca e cai.... não volta mais... com a cabeça embaixo d'água, debate-se até o fim do seu ar, mais um pouquinho e mais um pouquinho, dá uns catos e... formiga!).

Utilizo "formiga" e "fica fraca e cai" como falas que se revezam. Com "fica fraca e cai" cedo. A incidência de "fica fraca e cai" é instantânea. Ela corta (substitui) o efeito de "formiga", com a qual fujo da água (do beijo). É claro que a água é mais que o beijo. E suscita outras associações. O beijo é um enquadramento ficcional evocado pela ficção rodrigueana. Está no arranjo. É apenas um material. As descrições rodrigueanas fazem incidência. Como Nelson descreve o rapaz; isto tudo sugere associações. Mas é o revezamento entre "formiga" e "fica fraca e cai" que implica uma renovação sucessiva e pontual dos impulsos: uma fala é a contra ação da outra. "Formiga" traz uma memória: atolar o pé no formigueiro. Uma nomeação implica uma cadeia de significantes próprios de uma vida singular, de uma história só - e ajuda o ator no enlaçamento nas ações.

A personagem de Lars Von Trier no filme "Ondas do Destino" (vivida por Emily Watson) se entrega a homens cruéis, vai para o hospital e morre. Jogo com esta situação. A visualidade do filme é o subtexto da situação criada pelo Nelson Rodrigues: “(Eu sou outra pessoa!) Era outro homem. (O do filme) Fisionomia dura. Boca cruel. Olhos frios. (Coitada, o cinema tem dessas coisas) Quando eu abri a boca pra gritar". É o meu pensamento sobre a atriz ter de representar a moça que se entrega aos homens cruéis ("Coitada, o cinema tem destas coisas") - que coloco junto ao contexto pessoal: "Agora é o Fábio. Ele dá umas viradas. Disfarçou, mas eu peguei no flagra. De repente”. Utilizo o vivido de minha história íntima. As duas visualidades se revezam para a extração de falas internas que sustentam (com o texto falado): uma relação de substituição. Aproprio-me do meu pensamento, utilizando-o como material, e fixo no 
texto escrito para treinar a sua incidência (crio reverberação com a repetição da escrita). A fala interna sustenta uma ação subjacente à externa: "Quando eu abri a boca pra gritar" (e me dá vontade de gritar). A imagem do grito que dei no cinema (vendo a cena da Elimy Watson) se articula ao grito que dou ao espantar-me (na ficção) com Jorge; junto à "Mas aconteceu outra virada. É tudo muito rápido, é incrível quando um homem dá um rompante”: volto ao material extraído da minha própria vida.

(Agora é o Fábio. Ele dá umas viradas. Disfarçou, mas eu peguei no flagra. De repente) Eu vi a transformação. (Eu sou outra pessoa!) Era outro homem. (O do filme) Fisionomia dura. Boca cruel. Olhos frios. (Coitada, o cinema tem dessas coisas) Quando eu abri a boca pra gritar. (Mas aconteceu outra virada. É tudo muito rápido, é incrível quando um homem dá um rompante). Ele veio pra cima de mim e a minha boca foi fechada bruscamente.

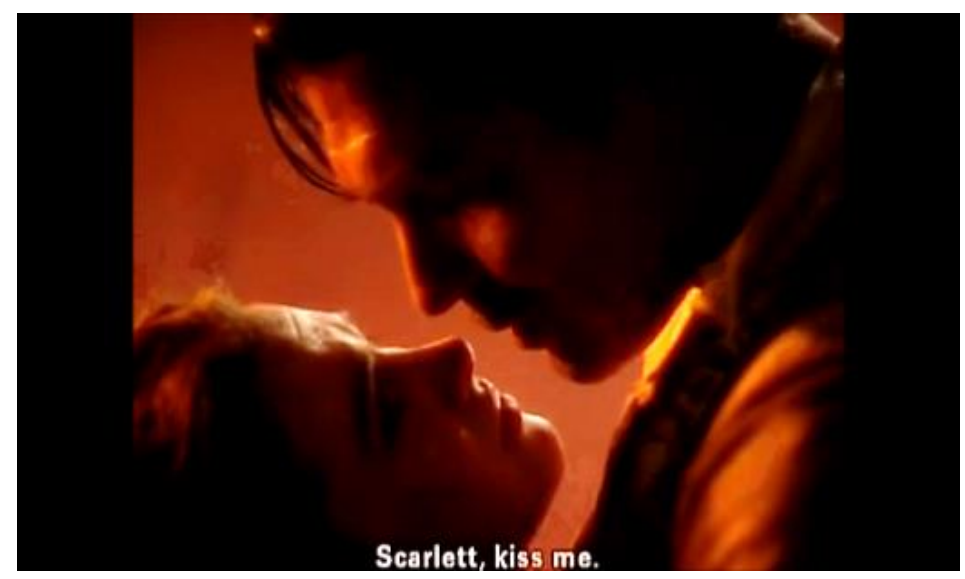

Figura 40: Projeção na "Cena 4: O Primeiro Beijo"

Este é um exemplo de pré-jogo. Em cena tenho os impulsos deste pré-jogo e o arranjo externo: há uma oposição, enquadramento. A frieza do vidro; as sensações do toque na água do aquário; o tempo que passa rápido demais ou lento demais. "O beijo" é enquadrado pelo arranjo externo: objeto, tempo, música, situação ficcional, projeção. A imagem do beijo entre Clarck Gable e Vivian Leigh (extraída de "E O Vento Levou") é projetada. Jogo com a coincidência do início e final dos beijos (projetado e vivido): "Consegue desprender-se da água, aspirando o ar, ao mesmo tempo em que Leight se livra de Gable e lhe estapeia. A imagem congela". A imobilidade (quase morte) com a cabeça dentro d'água. Acredito que isto suscite outras associações. Há defasagem. Não se trata de beijo. Há algo mais - mas o quê? Ainda estou investigando o material para utilizar no momento seguinte, em que fujo do aquário, me arrastando até a parede e rasgo o papel, descobrindo a grafia na parede: "Deus vai te castigar". Havia associado Juliane Moore em "Short Cuts" (de Robert Altman, 1993): a atriz se exaspera, limpando 
a roupa em meio a uma briga por causa de uma traição. A plasticidade do movimento faz incidência. Mas, penso: "E se vejo o aquário virando um homem e me assusto com a alucinação?" Esta incidência pode dinamizar o corpo. Estou pesquisando materiais para este momento.

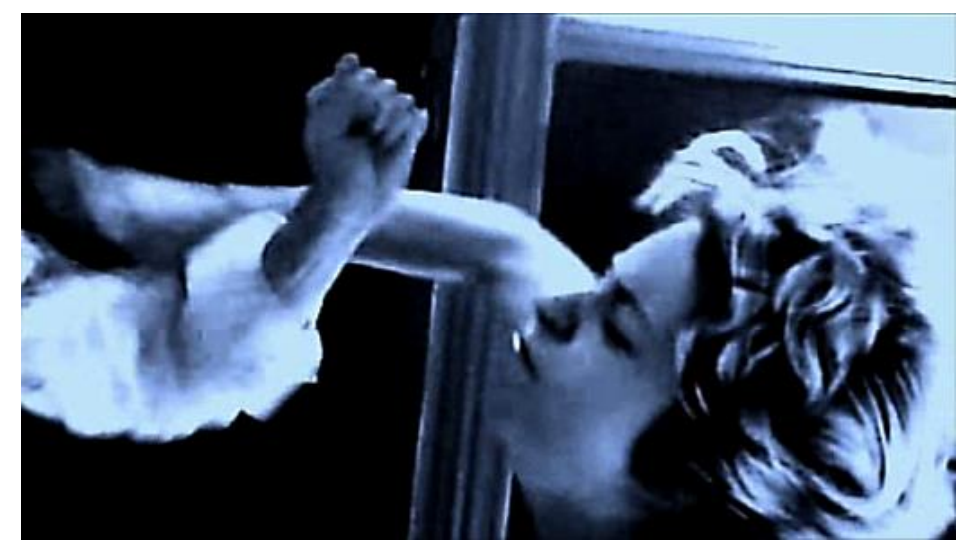

Figura 41:

Uma mulher esmurrando um homem (realização própria)

Imersa na plasticidade do passado, sonho e falhas de memória, posso sustentar a fala interna: "Onde é que meus olhos vão pousar?" - que passa à externa (inscrita em cena, sonorizada) e implica um mecanismo de busca por associações: a ação de procurar nas imagens do passado um fragmento de memória a ser revivido é a ação de procura de imagens para a encenação no contexto da atriz (para sustentar o corpo que deve evocar a relação com o pensamento). No vídeo projetado, a mulher voa para cima de um homem, enchendo-o de murros. A projeção oferece enquadramento plástico e sonoro com o som das respirações e tapas. Esqueço completamente o que devo fazer; paraliso com o buquê de papel crepom nas mãos. Na interlocução do CEPECA, apontam o momento como significativo. A imagem do corpo rememorada é campo para a extração da fala interna: "Não sei o que vem agora! O que faço meu Deus?" Espero que atualize a reverberação da impressão digital criada em improviso: ficar estática, diante do susto de não saber o que fazer (agora ação da personagem). No vídeo, a grafia da frase: "Torceu meu braço, virou meu pulso. Apareceram grandes pedaços do céu de um azul muito limpo”.

Na ficção rodrigueana está: "Suzana é igual à mãe, o tipo de mulher que só tem sossego na morte". Na interlocução com o CEPECA entrou no jogo que Suzana era como uma prostituta (um significante). Mas, para mim, ela era a garota de escola tímida e triste: "Eu tenho medo dos homens". Não gostava do beijo. Com quatorze anos o beijo pode ser insosso (a pele do outro é de borracha, não tem cheiro): espécie de histerilização, frigidez. Produzi outro vídeo, com o testemunho de uma mulher dizendo 
que aprendeu a beijar com dezoito anos e que o primeiro beijo, com quatorze, foi horrível. Queria defender a ideia de que a sexualidade não é algo dado, mas construção - e implica o desejo do outro. É quando o tio de criação beija outra garota (que se configura como a sua rival), que Suzana desperta. É através do desejo da outra menina que reage. "Tanto faz", diz ela, condenada pela falta de desejo (o oposto do que dela se pensa). Este é o imaginário da atriz, que serve como campo de extração de anteparos.

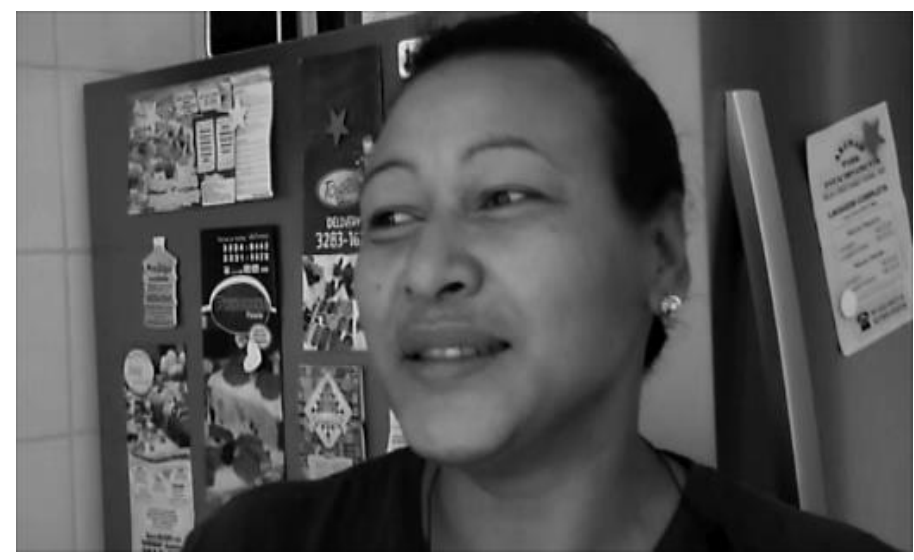

Figura 42: Depoimento de mulher sobre primeiro beijo mal sucedido (realização própria).

A voz diz: "Seu pai era a pessoa que eu mais amava no mundo. Agora é você. Eu vou tomar conta de você. Você será feliz. Eu juro. Ninguém tocará em você. Aristeu”. "Em que imagens o meu olhar vai pousar?".... Ela está estática com o urso em um dos braços, a mão apertando o sexo. Escuta os tapas, as respirações. Entra um bolero do Vadico. Em cena, ela coloca o chapéu e o sapato junto ao aquário, evocando uma figura masculina. Traz a cadeira bem para perto e a deita. "Em que imagens o meu olhar vai pousar..." Apoia a sua perna na perna da cadeira. Fecha os olhos ("Eu vou mergulhar") e enrola o tronco, firmando os braços. Solta o peso até sentir as costas no chão. Olha para o aquário, o rosto bem perto do vidro, a mão no peito. Deixando aparecer as cochas, cruza as pernas... Brinca com as figuras do Renoir... enquanto fala para o homem (visualizar o homem). Começa "E O Vento Levou”: Clark Gable se despedindo de Vivian Leight. "O pulso próximo ao rosto, o mindinho na boca, a mão delicadamente sobre o ouvido. Um Renoir. Toca levemente a perna abaixo do joelho. As duas mãos no cabelo. A esquerda mais para cima. O olhar baixo. A direita quase na garganta". Jorge. Eu me caso com você! (Abre bem a boca. Ouve a voz ressoando no espaço). Mas vou te trair na primeira oportunidade, serve assim? (Para a platéia) "Ei você!" Sabe o que ele me respondeu? Serve! (para a plateia) Observei que seus olhos eram entre o verde e o azul. Não pude deixar de pensar que era um rapaz bonito. Grita para o aquário: "Eu nunca suportarei um homem que não seja ciumento; que não tenha autoridade sobre mim; que não se imponha; que não me faça sentir absolutamente inferior!" (Agora é o Fábio. Ele dá umas viradas. Disfarçou, mas eu peguei no flagra. De repente) Eu vi a transformação. (Eu sou outra pessoa!) Era outro homem. ( $O$ do filme) Fisionomia dura. Boca cruel. Olhos frios. (Coitada, o cinema tem dessas coisas) Quando eu abri a boca pra gritar. (Mas aconteceu outra virada. É tudo muito rápido, é incrível quando um homem dá um rompante). Ele veio pra cima de mim e a minha boca foi fechada bruscamente. Com uma das mãos força a sua própria nuca e a cabeça dentro d'água. Formiga. Ela fica fraca e cai. Formiga. Fraca e cai. Enfia a boca dentro d’água. Fala lá embaixo. Não, por favor, eu não quero, por favor, não! Não quero!! Formiga! Como se 
lutasse com o homem até, aos poucos, se deixa levar pela volúpia... cada vez mais forte, enfia a boca e volta. Até que não volta mais... ao mesmo tempo em que Clarck beija Vivian Leight... Fica lá até o fim... do seu ar... até onde consegue.... Mais um pouquinho e mais um pouquinho... não volta mais... A Voz diz: "Se me perguntarem o que senti quando pela primeira vez que minha boca foi fechada com um beijo... (Não sei responder. Eu estava fria) Nada. Nem asco, nem prazer". (Eu era objeto. Objeto dele. Só que fiquei presa). Abraça o aquário. Com as pernas o enlaça... com a cabeça embaixo d'água, debate-se até o fim do seu ar, mais um pouquinho e mais um pouquinho, "dá uns catos" e... formiga! Consegue desprenderse da água, aspirando o ar, ao mesmo tempo em que Leight se livra de Gable e lhe estapeia. A imagem congela. Levanta com horror. Afasta-se em direção à parede. "Limpa! Sai! Sujou! Sai daqui!" Rasga o papel da parede em que está escrito "Entre nós a presença de uma morta". Aparece por baixo a frase "Deus há de castigar!" Fim do bolero. A cena é invadida pelo silêncio. Quando ele foi embora, eu não sabia o que pensar, o que dizer, o que sentir. (Vazia) A única coisa concreta em mim era o espanto! (Maluca) Depois o medo. (Maluca) E o ódio. Fiquei horas, parada, pensando no beijo. Era só fechar os olhos para sentir, novamente, a sensação da língua invadindo minha boca e se fundindo milagrosamente ${ }^{25}$.

\subsubsection{Visualidade da Loucura? "O Plano"}

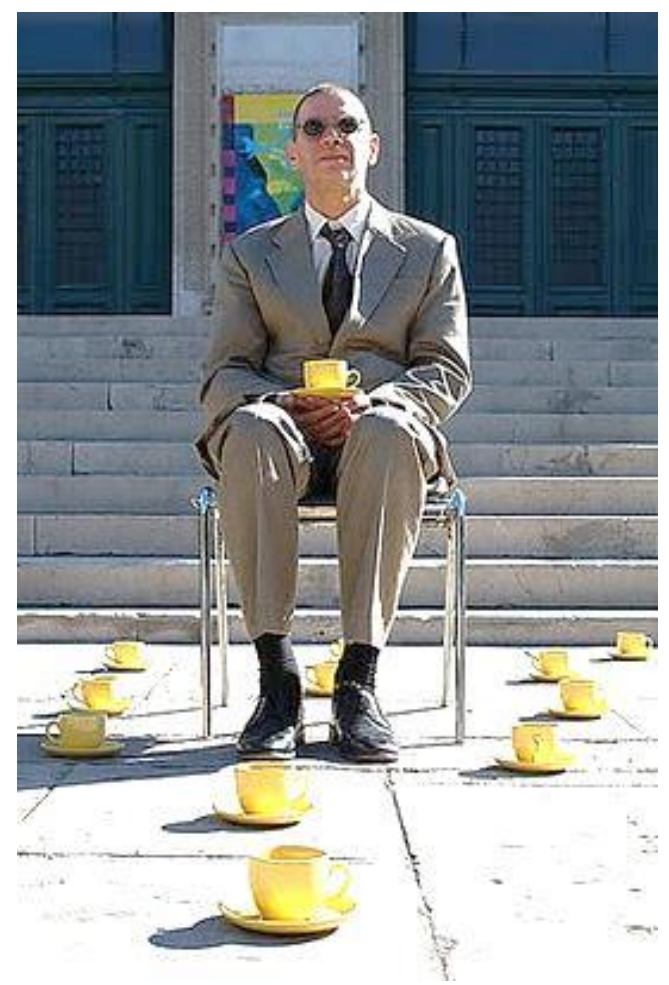

Figura 43: Nature morte de tasses de café (Roi Vaara, 2005).

Xícaras de chá entram no arranjo a partir da fotografia de "Nature morte de tasses de café", performance de Roi Vaara (2005): “Chegou mais gente!". O velório da mãe estava no início do romance. Coloco a frase depois do "Primeiro Beijo" e desloco a 
ação de receber os parentes para junto da descoberta do que o pretendente fez com uma ex-namorada: queimou os olhos da menina com a ponta do cigarro acesso. Suzana recebe as irmãs de Jorge junto com as tias e os demais parentes. Tiro muitas bonecas de uma grande mala. Uma a uma, vou colocando em cena diante do aquário, cada vez mais rápido. Sonorizo um poema, tecido com associações que tinham ficado de fora.

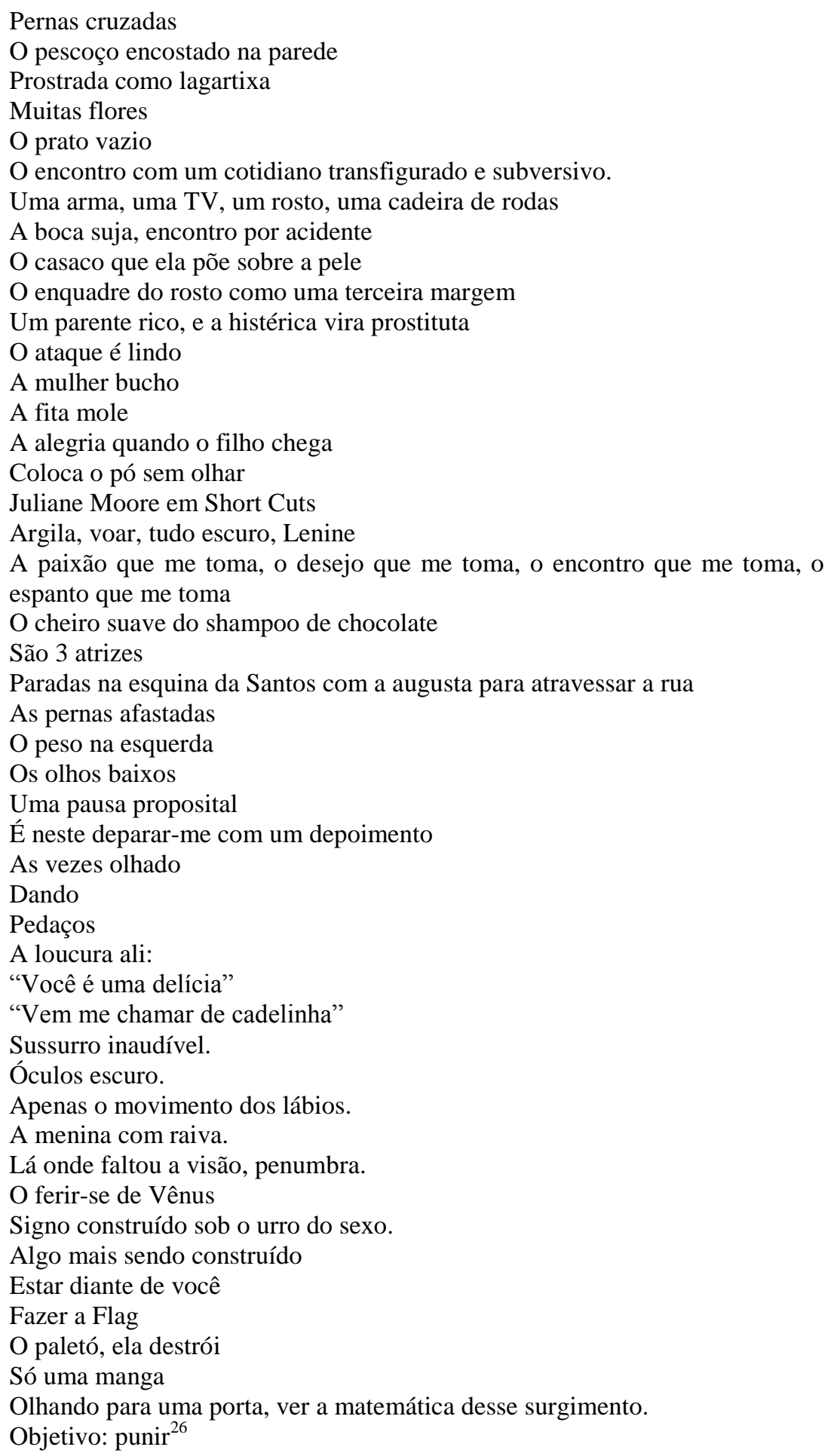

26 Poema tecido com associações que tinham ficado de fora, sonorizado em cena. 
São imagens do corpo, que nomeio. Vou anotando: palavras. Imagens do meu corpo: "parada na esquina da Santos com a augusta para atravessar a rua, as pernas afastadas, o peso na esquerda, os olhos baixos". São imagens do corpo cotidiano que tenho vontade de encenar: "Pernas cruzadas o pescoço encostado na parede prostrada como lagartixa" - cuja incidência precisa ser encenada. São músicas: "Lenine”. São fragmentos de memória ou fantasia. Um dia, me deparo com uma imensa lista destas associações. Corto algumas e sonorizo outras. O jogo destes enquadramentos externos articula um drama da escritora, que vive a escrita na carne e enlouquece? Visualidade da loucura? Uma refração, tal como um cristal que recebe a luz e abre um feixe em várias direções?

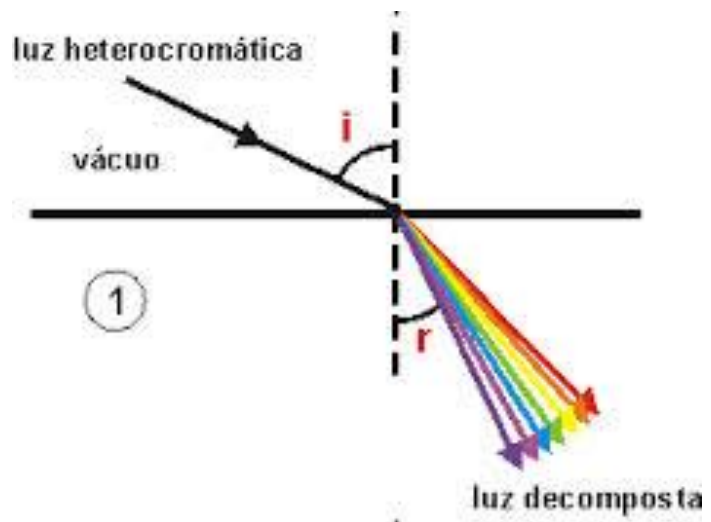

Figura 44: Refração

As bonecas. Primeiro uma. Depois trinta. São colocadas diante do aquário que a narradora beija. Para cada uma, repito a pergunta: "O que sentiu quando foi beijada pela primeira vez?". Uma memória: outra melhor amiga de infância beijada, estatelada, dura, o olho arregalado, em meio ao mar. Eu na areia olhando aquilo. A imagem fixa na memória. Eu mesma, desajeitada, quando fui beijada, sem saber o que fazer. O poema e a pergunta: as duas sonoridades competem e eu preciso falar mais alto que o audio. A excitação cresce. Aceleração da velocidade dos movimentos. A cena segue com a voz "das bonecas" na sonoplastia: contam que Jorge tinha queimado o olho da namorada com o cigarro aceso. E, também, sobre a ilha de Tio Aristeu, perdida no mar. A última boneca; o cumprimento: “Entre titio!”. Sento-me para escutar o plano de vingança. 
Vai até a mala. Pega outra boneca. Sente-se titio. Coloca-a sentada na caminha. Vai até o procênio. O senhor não imagina o que Jorge fez comigo! Vozes: "É uma ilha Suzana perdida no oceano, encantadora e tétrica". Senta-se. Os olhos iluminados pela luz da projeção. Voz firme: "Você gosta dele?"(Preciso responder?) Não. Voz: "Odeia?” (Se odeio?) Não sei. Voz: "Responda!"(Confesso) Odeio. Voz: "Seria minha cúmplice?” (Tempo) "Você vai para a ilha comigo. Você, Jorge, sua avó, suas tias e as irmãs de Jorge. Com todo mundo lá posso fazer o que quero". Não sei o que me fez olhar para a porta. Minha avó não se mexia. O olhar fixo como o de uma morta. Meu tio teve uma espécie de sorriso mau. "Você é igualzinha a sua mãe" - ele me disse antes de partir - (Comenta) Sei disso. (Lembra-se) Eu também devia parecer uma morta estendida na cama com medo até de respirar. Tive um arrepio como se fosse de frio, mas era medo. "Tenho medo dos homens".

O diálogo, quando repetido no pré-jogo (pela escrita), as suas palavras, trazem associações com outras palavras: pensamentos, falas internas. Estas outras são anotadas no pré-jogo. Com a repetição do pré-jogo, o imaginário vai ficando denso, a visualidade da relação se torna consistente e, também, os impulsos para as ações vai impregnando a memória corporal, criando ecos, reverberando. A escuta se avoluma em voz. É quase como se alguém soprasse nos ouvidos. Coloco um cochicho na régua sonora ao mesmo tempo em que falo em cena. É como se eu repetisse as falas das tias. Um material plástico é extraído de um relato do Dr. Oliver Sacks em "O homem que confundiu sua mulher com um chapéu" ${ }^{27}$. Uma das pacientes não sustenta o tônus muscular; desaba no chão, feito um trapo. Só consegue ficar de pé depois de meses olhando para cada parte do corpo, pacientemente, remontando-o, até constituir uma postura artificial.

Ficar em pé era impossível - a menos que ela olhasse para os pés. Ela não conseguia segurar nada nas mãos, que vagueavam, a menos que mantivesse os olhos fixos nelas. Quando tentava estender as mãos para pegar alguma coisa ou para se alimentar, as mãos erravam grotescamente o alvo, como se algum controle ou coordenação essencial houvesse desaparecido. Ela quase não podia sentar-se - seu corpo cedia. Tinha o rosto estranhamento sem expressão, frouxo, a mandíbula caída; até mesmo a postura vocal desaparecera. (...) "É como se o corpo estivesse cego. Meu corpo não consegue enxergar a si mesmo se perdeu seus olhos, certo? Por isso eu preciso olhar para ele. Ser os olhos do meu corpo, certo?” (...) Ela não conseguia fazer coisa alguma sem a ajuda dos olhos e desabava como um saco vazio se os fechava. Precisava, primeiro, monitorar a si mesma usando a visão, olhando atentamente para cada parte do corpo quando esta se movia, com uma consciência e cuidado dolorosos. Seus movimentos, monitorados e regulados conscientemente, foram a princípio desajeitados e extremamente artificiais (...) Três meses depois surpreendi-me ao vê-la elegantemente sentada - elegantemente demais, estatuesca, como uma bailarina fazendo pose. E logo percebi que seu modo de sentar era realmente uma pose, adotada e mantida de maneira consciente ou automática, uma espécie de postura forçada, deliberada ou teatral (...) ela recorrera ao artifício (...). Algo

${ }^{27}$ SACKS, O. O homem que confundiu a sua mulher com um chapéu. São Paulo: Ed. Companhia das Letras, 1992. 
semelhante ocorrera com sua voz - de início ficara quase muda. Também a voz era projetada, como de um palco para uma platéia. Era uma voz estudada, teatral (SACKS, 1992, p. 61-64)

Ao contar o caso para Evinha Sampaio, seleciono trechos. Reduzida, a fala vai para o pré-jogo como uma "descrição de corpo". As falas não têm a ver com a fábula de Nelson Rodrigues. Mas, intercalo-as; provoco trocas entre a menina atormentada pelas tias (situação rodrigueana) e a descrição de corpo extraída do relato de Sacks - a espera de efeitos de ação para a narradora em cena. Experimento variações, para que as cadeias formem acordes. Vou enquadrando, na ficção, as ações que a descrição de corpo evoca. Faço isto durante as repetições do pré-jogo. A escrita corporal se instala como material que assume um valor na narrativa: os movimentos são significantes inscritos em uma cadeia passível de ser lida, interpretada, a partir da visualidade de uma ficção. O enquadramento plástico implica uma escuta. Durante a escrita do pré-jogo também me lembro de uma canção com o nome da minha mãe.

Esta é a doente do Sacks que perdeu a percepção do corpo. Teve que construir a coluna. Ela faz os movimentos e em uma espécie de susto. Quem é?! Me encarou com os ouvidos. Sou eu, tia Laura! Abri a porta. Ela entrou. Quis acender a luz e ela. "Não!" A doente do Sacks canta para se mexer. Cantarola. "Água dos Igarapés onde Yara a mãe d’água". No escuro, sentamos na cama. Cantarola. "É misteriosa canção. Água que o sol evapora". Deixa cair a xícara no pires, se afasta para o lugar da tia. Deixa a xícara na cadeira no lugar da menina. Olha o local onde supostamente a menina está sentada. A doente do Sacks teve que construir as mãos. Já te falei!!! Um estranho, um desconhecido. Tio coisa nenhuma! E sabe porque? Para ele você não é sobrinha, é mulher! Ela canta para se mexer. Coluna. Escapei pelo corredor e quase esbarrei em tia Hermínia. Levanta-se. Ficar em pé era impossível. Estava insegura das pernas. Não sentia nada sobre o chão. Aquela vertigem. A menos que olhasse fixo para os pés. Puxou-me pelo braço. Puxa o cabelo. "Venha já para o meu quarto!" Não sentia nada com as mãos. Que sacudiam a esmo em todas as direções. "Quero te contar uma coisa que aconteceu. Jorge e sua mãe". A mão vagueava a ermo a menos que fixasse os olhos nelas. Eu já sei! Se acalma antes de se sentar novamente. Ela brinca com os gestos da cegueira da avó.

Durante as escritas do pré-jogo surge um ritmo. Este ritmo vai para a cena. Junto está um anteparo plástico que chamei "Coluna" - e a nomeação "Aquela vertigem". Quando repito a escrita, sinto o impulso destes anteparos cravados na tessitura corporal. Em cena, no improviso para o CEPECA, o impulso reaparece. 


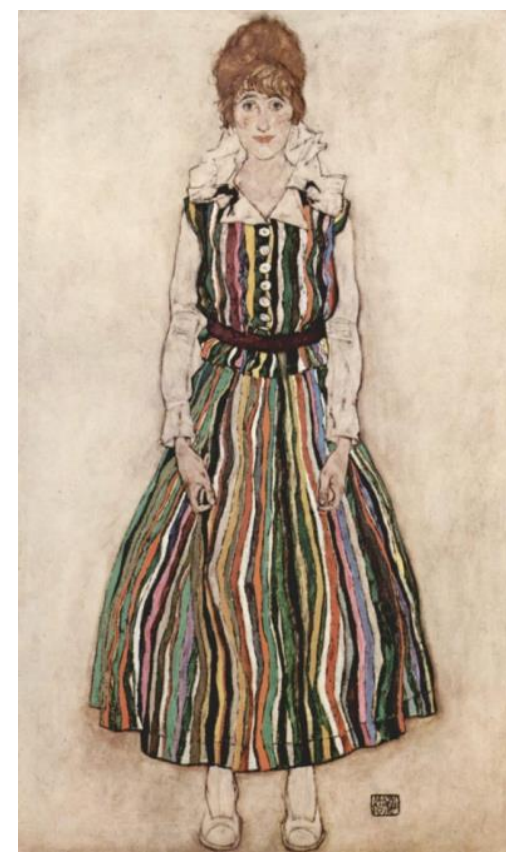

Figura 45:

Anteparo "Coluna"

Antes de ir à cena, o pré-jogo é reduzido - alguns pedaços caem por terra. Há absorção. A crise do corpo passa para a narradora: a menina pressionada sucumbe. Uma visualidade é absorvida na outra. Aparece a lógica do drama, que se constrói trocando, juntando, cortando. Mas a descrição de corpo, sonorizada, estranha: “A doente do Sacks teve que reconstituir as mãos”. É postiço. Sua artificialidade aparece. Existe o que se inscreve em outra lógica: uma poética da cena? "O caminhar dos filmes do Béla Tarr”: é como nomeio o jeito de caminhar da garota de "Sátántangó" (filme de Béla Tarr, 1994). Esta nomeação também é sonorizada, além de incorporada na narradora. Tal como com a grafia das palavras, eu leio os gestos, mas há algo que é marca ou vinco. Esta marca às vezes se apaga, dilui.

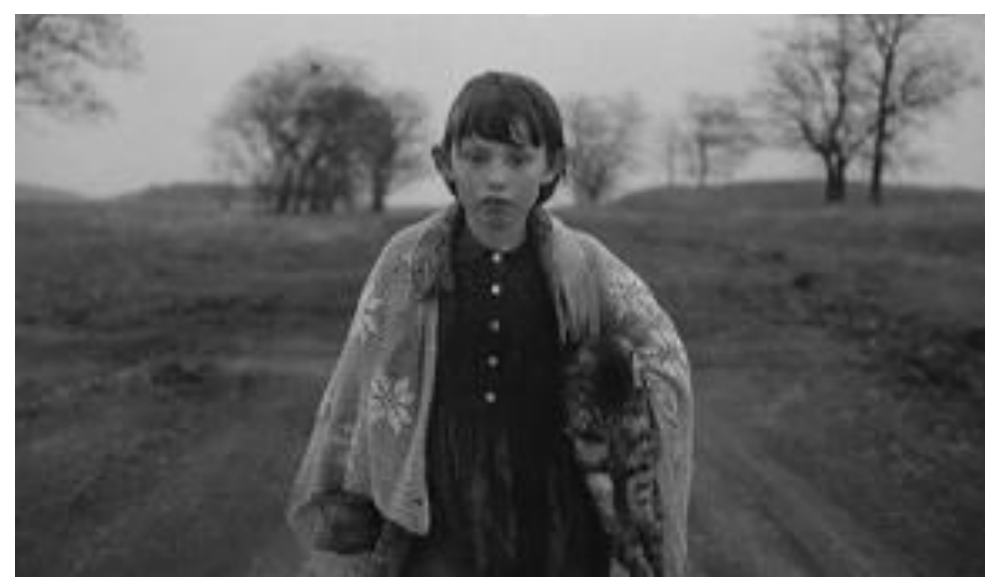

Figura 46:

Sátántangó

(Béla Tarr, 1994) 
Sonorizo vozes infantis: "Suzana vai pro convento! Suzana vai pro convento! Suzana vai pro convento”. Esta frase é rodrigueana. Enquanto escrevo, sua sonoridade ganha densidade. Impregnada da sua incidência, gravo-as. Em cena, tendo fazer parar as bonecas (que estariam falando). Movimentos da Pina Bausch são absorvidos nesta ação. Movimentos que fico incorporando como um aquecimento (momentos antes do CEPECA chegar) - enquanto penso: "Pára! Pára!" (fala interna).

\begin{abstract}
Entra a sonoridade enigmática da trilha do filme A Liberdade é Azul, do Kieslowsky. Junto com a música, entra a sonoplastia da própria voz.Voz: "Vai até um delicado armário de vidro anos cinqüenta esquecido no canto do quarto (tempo) $O$ andar dos filmes do Bela Tarr. Pega o bule de chá e as xícaras. (Tempo) Traz. (O ouvir do Hugo nos ouvidos) Chegou mais gente! (Vai até a mala. Abre-a de supetão. Aparecem bonecas. Pega uma. Quase infantil) Tia (Kátia) Hermínia! (Pega mais três. As coloca em pé diante do homem. Busca mais bonecas) Tia (Tânia) Laura! (Coloca diante do vestido caído que, na sua brincadeira, representa o corpo da mãe) Perguntei à queima-roupa: "Uma coisa titia, eu queria que a senhora me dissesse o que sentiu quando foi beijada pela primeira vez". (Vai novamente até a mala. Mais três bonecas) As irmãs de Jorge demoraram pra chegar! Problemas com o transporte (Coloca-as ao lado do corpo) Noêmia! (Coloca outra) Maria Luiza, com certa melancolia. (E outra) Maria Helena. (Segreda) Contaram sobre Jorge. (Gira em círculos, agitada. Entra a Voz) "Uma vez gostou de uma menina, você não faz idéia, um dia se ausentou e voltou inesperadamente, pegou a talzinha com um rapaz em pleno beijo. Levou-a de arrasto, rasgando o joelho nas pedras. Puxou um cigarro e... pôs a brasa do nos olhos dela". (Senta-se. Tira os sapatos. Desolada) Acho isso pior que matar. (Muda o assunto) Em imaginação, viam a ilha deserta do tio Aristeu! Voz: "É uma ilha, Suzana, sozinha no meio do oceano, encantadora e tétrica" Vozes: "Suzana vai virar freira, Suzana vai entrar pro convento! Suzana vai virar freira, Suzana vai morar num convento! Suzana vai virar freira! Suzana vai morar num convento!"
\end{abstract}

\title{
2.2.6. "Quens" em Jogo
}

No romance está uma narradora em primeira pessoa: Suzana Flag, pseudônimo com o qual Nelson Rodrigues publica folhetins nos Anos 40. Entra em jogo esta década e coloco um rádio antigo em cena. Vem-me a ideia de que a avó poderia estar ouvindo novela no rádio. A voz de Ofélia devolvendo os presentes para Hamlet encontra um enquadramento ficcional a posteriori. A associação com Hamlet tinha vindo devido ao desejo de vingança da morte do pai. Veio de uma interpretação: "Ela é como Hamlet!" (desejo). Interpretei Ofélia em 1997; as falas ainda estavam vivas. Gravei e coloquei em cena. 
O pseudônimo de Nelson Rodrigues traz para o jogo a figura da mulher fatal que poderia se configurar como um "Quem" spoliano ${ }^{28}$ :

\begin{abstract}
Às vezes, não sempre, tenho uma raiva de umas tantas coisas que existem em mim e que atraem os homens. E, nessas ocasiões eu deveria ser feia ou, pelo menos desinteressante, como certas pequenas que impressionam um homem e não todos (RODRIGUES, 2003, p. 09).
\end{abstract}

No entanto, este "Quem” não me estimula e provoca uma resposta: "Não quero construir assim a Flag". Outro "Quem" estava presente nas interlocuções no CEPECA: "prostituta". Suzana responde ao desejo dos diversos homens, ora se atraindo por Jorge, ora por Aristeu (o tio de criação), ora por Claudio (capataz que ajuda a família a fugir em troca de carinho). Em encontro no CEPECA cito um trecho (que então sonorizo): "Como daquelas prostitutas célebres que fazem morrer os poetas". Sonho de menina tímida. Para mim, era a garota de escola triste e esquisitona que virou a altiva escritora. Mas era possível também associar "bagaceira". A dúvida sobre o contexto na narradora perdura até o "Quem" escritora definitivamente se instalar. A visualidade da experiência com a Memorização Através da Escrita começa a ser explorada em cena no dia em que, me aquecendo com a repetição do pré-jogo enquanto esperava o CEPECA, pouco a pouco, rompo com a imobilidade e caminho de um lado a outro, sem parar de escrever, com pequenas transformações nas bordas corporais. O movimento evoca a minha mãe perambulando pela casa, anotando os pensamentos em papeizinhos. Quando a imagem invade o meu olhar, evoca uma escritora perdida no mundo de memórias e invenções; imagens distribuídas pela "casa": figurando a subjetividade, onde um desejo se anuncia.

O termo "superobjetivo" é utilizado por Stanislavski como "sentido íntimo" (STANISLAVSKI, 2005, p. 99): a produção de uma frase que dá unidade a obra, circunscrevendo o seu sentido. Segundo Knébel, ele pode ser "do personagem”, “do ator", "do diretor" ou "da obra" - e se transforma durante o processo de criação ${ }^{29}$. O superobjetivo de mostrar o quanto a escrita é incidente, o quanto implica um corpo, constrói o corpo, sustenta um imaginário: a escritora escreve e vive as cadeias escritas; uma plasticidade de quem é "bombardeado" pela incidência deste ato, o suficiente para viver a experiência como real; como se a grafia fosse enquadramento; como se a

\footnotetext{
28 Viola Spolin propõe Jogos Tetrais (improvisações estruturadas) com um "Quem”, um "Onde" e um "O quê", materiais isoláveis que, com sua incidência, criam resultantes. Diferentes "Ondes", "Quens" e "O Quês" são combinados entre si. Há um sistema de trocas e composição de diferentes arranjos. Ver: SPOLIN, Viola. Improvisação para o Teatro. São Paulo: Ed. Perspectiva, 1992, p. 81-129.

29 Ver também: KNEBEL, M. Poética de la Pedagogía Teatral. México, Siglo XIX, 2002.
} 
personagem vivesse dentro da grafia, corporalmente enquadrada. A posteriori este "Quem” articula também a ação de pichar os pensamentos da personagem - que já estava presente em cena: "Fiquei dias tremendo de febre, ao meu lado minha avó"; "Entre nós a presença de uma morta".

Mas continua havendo outros "Quens". Deparo-me com Barbara Stanwick, atriz de um cinema dos Anos 40 que influenciou Rodrigues ${ }^{30}$. A figura evoca: elegante, altiva, cruel, contenção, dissimulação. É possível recortar: o movimento dos dedos, o andar.
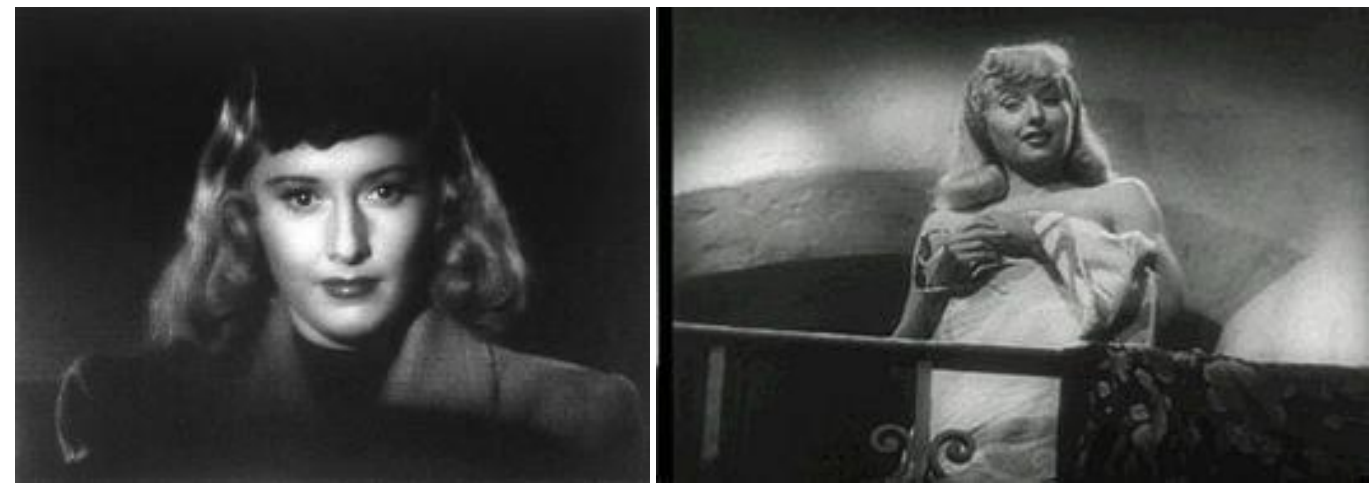

Figura 47: Barbara Stanwick em "Pacto de Sangue” (Billy Wilder, 1944)

A menina de "Cria Cuervos" (Carlos Saura, 1976) é lembrada no diálogo com Evinha Sampaio. Conversamos: ela associa a estranheza (Suzana menina observa com fascínio a morte da mãe).
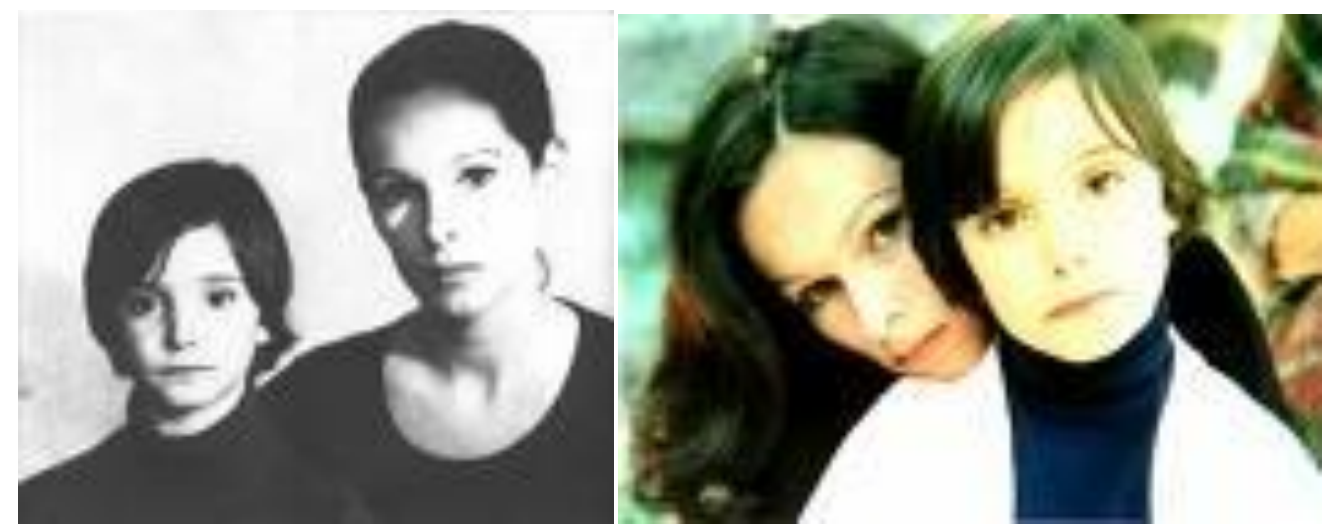

Figura 48: As atrizes Geraldine Chaplin e Ana Torrent em “Cria Cuervos”, Carlos Saura, 1976.

3o A mimese de uma atriz no cinema não implica um arranjo onde a atuação naturalista se constitui. A imitação da figura implica a visualidade de uma representação. Há outro momento, onde mexo na sandália e falo em nome próprio sobre a vida: um corpo cotidiano, despojado de uma elaboração formal e enquadrado pela atividade de mexer na sandália que divide o foco com a fala externa: este arranjo está mais próximo da atuação realista. 
Quando associo uma palavra a partir do que a imagem evoca, a incorporação se dá com maior facilidade. O enlaçamento da figura no corpo acontece no momento da verbalização. Este é um caminho para estas imagens se instalarem como enquadramento plástico-corporal nas impressões digitais: com a nomeação ou a descrição. A nomeação "Cria Cuervos no Corpo" começou a ser utilizada no pré-jogo. Pode evocar o desprezo junto a: "Se dizia meu noivo" - ou produzir outros efeitos conforme o arranjo.

Deparo-me com Anecy Rocha em "Lira do Delírio" (filme de Walter Lima Júnior, 1969) e me encanto com a sua figura delirante. Prostituta e debochada, a figura associa algo oposto a Stanwick. Uma complexa cadeia está articulada a incidência da imagem de Anecy no arranjo. Crio uma fala interna: “A Flag dá uma de escritora, toda chique, mas não é nada disso não gente: ela gosta é de boteco! Vive no boteco da esquina! E adora ser mulherzinha!". O que chamo "texto do processo" são estas cadeias de associações, que se desdobram - nos diálogos de bastidores também.

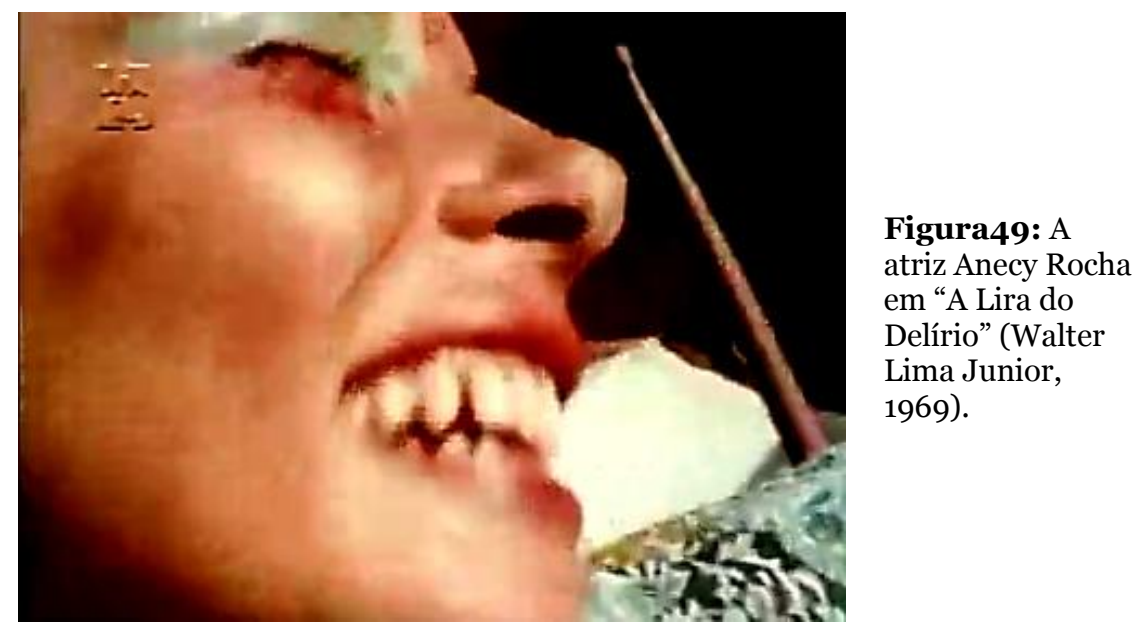

Para que esta fala fosse enunciada em cena, houve um improviso no CEPECA. Neste improviso pedi que me batessem. Este improviso foi preparado com um pré-jogo que, por sua vez, contou com um complexo arranjo de materiais sobrepostos. Nele estão implicadas imagens de atrizes-pesquisadoras do CEPECA rompendo limites da cena; e também a associação com um êxtase (veiculado à pulsão de encená-lo como “da Flag”). As imagens de Maritza Frías Cerpa e Débora Zamariolli são associadas a partir de um estado de êxtase, vivido no contexto cotidiano: a sensação de liberdade e despojamento que eu quero encenar como sendo da Flag. Uma risada, junto à ação de urinar em cena 
de Maritza Frías Cerpa ou o desnudamento de Débora Zmariolli vem à mente como um signo da exacerbação, da ruptura de limites, do disparate (há pulsão de encenar isto).

Antes do improviso no CEPECA começo a escrever. Penso: "é assim que a Flag se sente" (a fantasia como um campo de extração). É este significante que associa Anecy Rocha em "A Lira do Delírio": o êxtase em meio ao samba; a inconsequência; a entrega ao delírio no percurso do filme. Deixo fluir a escrita até articular o contexto da personagem: a narradora aborda o público. Depois de escrever bastante em nome da personagem, começo a memorizar as falas (pela repetição da escrita); reduzo-as (corto várias) e adapto-as ao meu contexto. Tomo a situação "da Rejane" como "paralela" (análoga) à situação “da Flag” (a "situação paralela” como campo de extração).

Por uma coisa no lugar de outra não deixa de ser uma operação da linguagem; uma operação metafórica. Trata-se de um material de apoio. A operação é sistematizada por Uta Hagen: "Toda fase de pesquisa do papel requer incontáveis substituições a partir da experiência de vida (...)” (HAGEN, 2009, p. 54). Trata-se de uma substituição de um significante (ou cadeia de significantes) por outra:

Em "Amar é Sofrer", há um momento em que Bernie Dodd chama Georigie Elgin de "cadela". Isso deveria exercer em mim efeito profundamente ofensivo, ultrajante, e produzir um suspiro de choque. Mas a palavra em si não me diz muita coisa. E a substituí por outra. E se ele me chamasse de "..." ? Essa palavra, sim, me choca e me ofende. Imaginei que Bernie me lançava essa palavra, e ela me arrancou da cadeira (idem, p. 61).

No caso desta "situação paralela" não é apenas uma palavra que é substituída, mas uma rede delas, com muitas cadeias de sustentação daquele imaginário, daquela situação outra que não é "da Flag”, mas "da Rejane” (e que imprime outra visualidade, apesar de, imaginariamente, algo articular uma a outra). Elas são "paralelas" (existe uma analogia entre elas). Uma maneira de instalar incidência para a improvisação é este deslocamento das palavras da Flag para a situação da Rejane, que implica uma memória viva no corpo. As poucas falas restantes do texto são escritas diversas vezes (para marcar o corpo). Crio uma fala interna; pensamento escondido, íntimo (“da Rejane”) para situar o foco. No arranjo não está uma fala externa pré-determinada (é a regra do jogo); o elemento fixo é um punhado de falas internas articuladas ao próprio contexto através de uma fala (só) inventada na hora, que situa o foco de atenção no instante da entrada em cena. O que enquadra os efeitos da sua incidência sobre o corpo - e da atualização das outras falas (através da sua reverberação na tessitura corporal) - é a 
relação com o público, bem como associações a partir de uma escuta da cena (que se desdobram imprevisivelmente).

Este é um exemplo do pré-jogo (a escrita de um texto do ator como preparação da cena) sem a fala externa oferecida pelo autor. Também não há o enquadre fixo do movimento, mas utilizo a rememoração de música interna (escuta solitária, escondida, íntima, segredada). Com o foco na incidência da música interna, movimentos (e ações) são criados em improviso. Movimentos são atualizados na tessitura corporal e evocam ações "da prostituta" (significante em jogo). A música interna oferece apoio. O enquadramento das ações e movimentos é criado em função da relação com o outro e a situação. Atrás de mim, há uma projeção: a briga de um casal. A imagem congelada; os cabelos da mulher para cima. Tenho uma garrafa d'água na mão e uma peruca loira que não tenho vontade de colocar. Ando de um lado para o outro, evocando a espera por um carro. De repente, rompo "a quarta-parede" e os alerto que a Flag não é uma escritora, mas prostituta. A instrução de abordá-los é um material fixo (instrução de jogo), mas não sei o que vai vir. Estáticos, se mantém a espera do que eu vou fazer. Como não se mexem; eu repito o pedido para que me batam e argumento que mereço. Há algo entre mim e eles, que se instala e incide: a visualidade de uma relação.

Em jogo, entram anteparos que Stanislavski sublinha: o "objetivo"31 (pois eu realmente queria que um deles se levantasse e me batesse e insisti naquilo). Mas, este objetivo não havia sido isolado antes; ele foi descoberto a partir da experiência cênica (e pode ser desdobrado em fantasias preparadas pela escrita para material de incidência). Deparo-me com "fé cênica", "senso de verdade"? São os termos que Stanislavavski utiliza, mas a noção de verdade é problemática. Em outros termos poderíamos dizer que existe um enlaçamento com a tessitura da relação naqueles instantes; um engajamento situando o foco em um entre dois e todo o resto some, não cabe no olhar. Com o olhar todo ocupado pela visualidade daquela relação; a visualidade da representação se perde. Quanto à "fé cênica” o termo indica uma identificação com algo que não seria passível de acontecer, mas articula uma fantasia? O sentir-se vivendo a situação, ação, relação implicaria o desejo de vivê-lo? Não a ação ficcional (apanhar), mas a sensação de tornar algo real - de assustar, de fazer o olhar "acreditar" o suficiente para alguém levantar da cadeira (e "desacreditar", porque apesar de parecer aquilo não pode ser real).

${ }^{31}$ Ver: STAnislaVsKi, Constantin. A Criação de Um Papel. Rio de Janeiro: Civilização Brasileira, 2005, p. 72-76. 
A visualidade de um ato de representação se perde em uma relação produzida "como se" fosse verdade. Há sensação da concretude daquele ato, da relação e do risco: "Você corre o risco de alguém levantar e te bater" (CEPECA, 2011). A interlocução com o CEPECA entrou na cadeia associativa durante a semana. Pensei em combinar com um deles (que estaria presente nas apresentações) a simulação de uma surra. Seria uma oportunidade para experimentar algo de realismo no espetáculo e refletir sobre uma tensão: entre o enquadre pelo movimento (que seria coreografado) e este constituído da relação com o outro (enquanto a fala interna faz incidência). A leitura sobre o improviso entrou na cadeia de associações: "Algo do desbunde; algo mais Dercy Gonçalves" (CEPECA, 2011): em resposta à interlocução. A imagem de Anecy Rocha a posteriori se torna um campo a mais para a extração, nomeação e descrição, bem como o detalhamento do pré-jogo. Aproxima-me do cinema brasileiro, com as suas figurações do desbunde, do melodrama e, por ora, do realismo. Mas o improviso da fala externa não foi o padrão dos arranjos. Na maioria dos arranjos, tomei frases de "Minha Vida" como anteparos verbais. 


\section{Bordas}

Eu era ar, espaço vazio, tempo

E gases puro, assim, ó, espaço vazio, ó

Eu não tinha formação

Não tinha formatura

Não tinha onde fazer cabeça

Fazer braço, fazer corpo

Fazer orelha, fazer nariz

Fazer céu da boca, fazer falatório

Fazer músculo, fazer dente

Eu não tinha onde fazer nada dessas coisas

Fazer cabeça, pensar em alguma coisa

Ser útil, inteligente, ser raciocínio

Não tinha onde tirar nada disso

Eu era espaço vazio puro.

(Patrocínio)

\subsection{Indícios de uma Estrutura}

\subsubsection{A Instalação da Figura em Cena (Olhar Dentro e Fora)}

Além de um arranjo de materiais externos (que não dependem da atualização através da tessitura corporal do ator) - projeções, objetos, limites oferecidos pelo espaço e tempo - o jogo de configuração cênica implica o desenho das bordas corporais, que pode implicar uma poética plástica, com relações de deformação, precisão, diluição, limites que se alargam e a evocam significantes específicos (como boneco ou morto, por exemplo). Coloco as imagens extraías das artes plásticas e fotografias da internet no blog (para depois olhar em perspectiva crítica). Hopper, Renoir, Modigliani, Manet e outros. Estas imagens podem ser encadeadas em uma ordem fixa, incorporadas e treinadas, repetidas, constituindo uma partitura (física). Era assim que fazíamos nos treinamentos pré-expressivos com Beth Lopes ou Yan Ferslev ${ }^{1}$. Na medida em que entravam em arranjo com outros materiais (uma fala ou uma situação, por exemplo) as figuras corporais se transformavam - restando delas um resíduo. Mas, estas figuras podem, também, permanecerem soltas, para invadir a cena, quando corporificadas em impressões digitais (através da área aberta entre a incidência do material oculto e o

\footnotetext{
${ }^{1}$ Profa Dra Elizabeth Lopes (professora doutora na USP e encenadora) e Jan Ferslev (ator do Odin Teatret, companhia de Eugênio Barba).
} 
espaço-tempo cênico). Como o enquadramento plástico-corporal está livre, elas podem aparecer em qualquer lugar do encadeamento cênico.

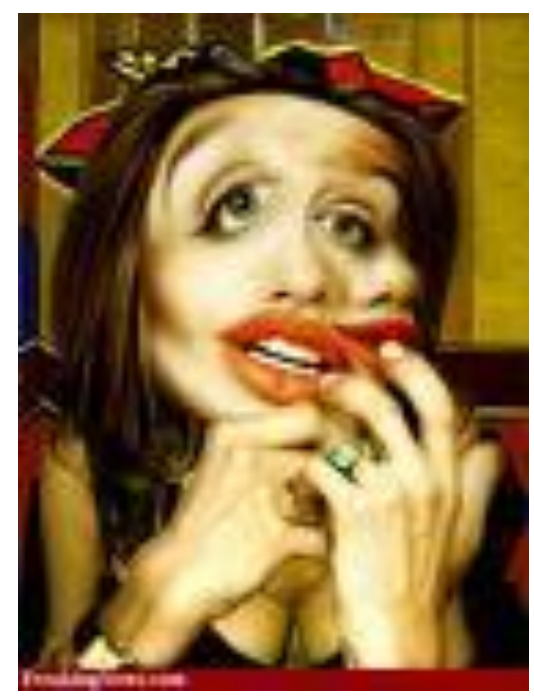

Figura 50: Montagem

fotográfica (inspirada em Picasso) extraída de um blog ${ }^{2}$

Momento seguinte ao "beijo". Mexo na boca e, repentinamente, a associação aparece: vejo-me com o corpo desenhado pela figura da montagem fotográfica inspirada em Picasso extraída da internet. Sem ter planejado, o desenho está na impressão digital, enquadrando-a. A associação repentina (no mesmo instante da escuta do corpo) reforça a incidência da figura assumida como enquadramento. $\mathrm{O}$ corpo se molda à associação ao mesmo tempo em que a atualiza ${ }^{3}$. E na cena "A Prisão", quando mostro os seios, não haveria uma incidência da figura abaixo, que já tinha sido escolhida para entrar no blog?

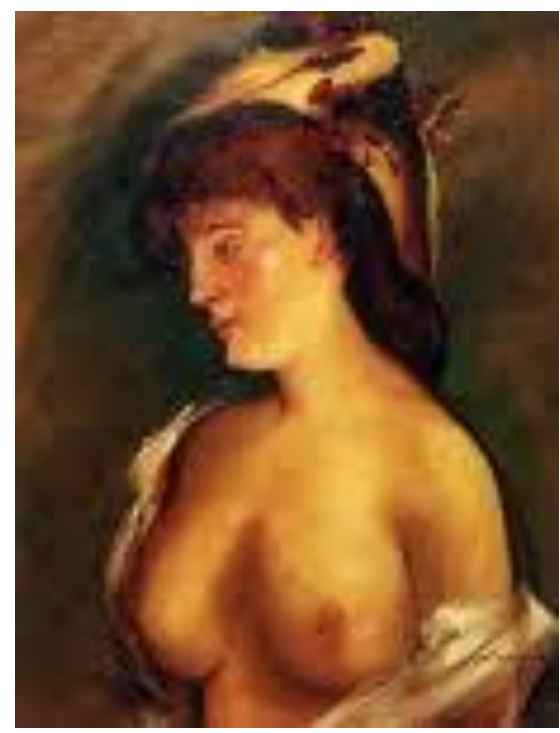

Figura 51: Mulher Loura com os Seios Nus (Manet, 1878)

${ }^{2}$ http://quebabado.wordpress.com/tag/pablo-picasso/ Acesso em 25/12/2013.

3 O termo "atualização" vem da psicanálise lacaniana com o sentido do que vem pelo corpo, do que aparece no corpo. 
A posteriori, fica clara a incidência do tema da sexualidade. Parece que tudo se articula em função da encenação de uma incidência que veicula um desejo: tematizar a mulher como objeto ou o corpo como objeto do deleite do outro - tomado na posição de significante (de uma diferença). Esta interpretação oferece materiais. O significante não é somente uma palavra, mas um elemento "diferente" dos outros. As imagens assumem um estatuto de significante, tal como as frases na parede: materiais que se empilham, deslocam, substituem. O significante para Lacan é uma "diferença": "O significante, em si mesmo, não é nada de definível senão como uma diferença para com um outro significante. É a introdução da diferença enquanto tal (...)” (LACAN, 1996, p. 194). Com os anteparos acontecem: a substituição (metáfora) e o deslocamento, quando um material aparece, lá adiante, cravado na impressão digital (deslocou-se).

A linguagem tem dois eixos: o vertical é o eixo de associações - de materiais empilhados, não necessariamente presentes, mas "presentes na ausência”. A metáfora está neste eixo. Há um segundo eixo, que é o eixo horizontal: os materiais sequenciados. Neste eixo, há deslizamentos, deslocamentos. Um material (presente na verticalidade) rouba o lugar de outro (e aparece). Para Lacan, a metáfora é uma operação metonímica e a metonímia é a operação da linguagem por excelência. Ela implica que a relação entre um significante (imagem acústica) e um significado (conceito) tem algo de barrado. A partir de como Sausurre elabora as duas partes que fundam o signo - e que ele escreve com a figura s/S (significado sobre significante) - Lacan destaca a presença da barra e inverte os termos, dando primazia ao significante: S/s. Esta operação (do significado ser barrado) implica um movimento e uma instabilidade nas cadeias, que “giram” em torno de um lugar de não inscrição: barrado".

De alguma forma, o corpo cênico está implicado nesta operação, encarnando os materiais quando aparecem na cadeia - e são "olhados" (em uma associação), além de encarnados. Quando fui para o "X Congresso de Crítica Genética" em Porto Alegre, no começo de 2011, ouvi de um dos pesquisadores da mesa coordenada pela professora Cecília Salles que Rubens Correa, antes dos ensaios, ficava olhando imagens em livros de artes plásticas. Quem o visse, depois, ensaiando, percebia as figuras reproduzidas no corpo. No entanto, o ator não havia definido a anteriori as ações com as quais fariam conjunto. As figuras se deslocam e invadem a cena, tomando corpo. Enquanto algo faz

4 Ver em: LACAN, J. Função e campo da fala e da linguagem. In: Escritos. Rio de Janeiro, Jorge Zahar Ed., 1998. 
incidência, a figura, cuja reverberação é "presente na ausência", se aloja como auxiliar da criação; reaparece em função do jogo de enquadramentos, transformada.

Há um princípio de Spolin: se desvio o foco de atenção para um material, outro se instala "espontaneamente": “Importante no jogo é a 'bola' - o Foco, um problema técnico, ‘as vezes um duplo problema técnico que mantém a mente (um mecanismo de censura) tão ocupada (...) que o gênio (espontaneidade), sem proteção, 'acontece,", (SPOLIN, 1992, p. 21). "Essa singularidade de foco num ponto (...) libera o aluno para a ação espontânea e é veículo para uma experiência orgânica" (idem, p. 22). O foco pode estar na instrução de jogo, fala interna, uma dificuldade técnica ou "problema a resolver". Em cena, a resolução de problemas traz a criação: "A energia liberada para resolver o problema, sendo restringida pelas regras do jogo (...) cria uma explosão ou espontaneidade" (idem, p. 05). Para "resolver o problema" do enquadramento da tessitura corporal no espaço-tempo cênico, o ator conta com materiais auxiliares, que se instalam na impressão digital.

Mas uma imagem só se instala de maneira espontânea se não situarmos o foco nela? Se não planejarmos a sua instalação, que deve ser realizada com a incorporação repentina? As improvisações de Viola Spolin contam com o planejamento de materiais fixos, mas que, no entanto, se mantém soltos: "Onde", "Quem” e "O quê". A questão não é a instalação planejada, mas a instalação "sequenciada" planejada: cada material amarrado em um lugar determinado de uma sucessão, para que entre, um atrás do outro, em ordem. Há modalidades de jogo onde se coloca a regra da atualização de uma partitura física. A sua atualização também implica um ponto de risco, pois a carne por onde ela se atualiza é viva. Se o movimento da partitura física enquadra, mas há outros materiais fazendo incidência (interna), existe uma pressão, uma tensão (existem dois materiais e não um; dois lugares na estrutura e não um). $\mathrm{Na}$ brecha entre os dois materiais, a resultante é fresca, digital. Com o corpo, mesmo um enquadramento fixo, implica a contingência de incidências no momento.

A rememoração repentina da imagem do "gesto psicológico" (Chekhov, 2003) ${ }^{5}$ de Maritza Farías Cerpa ${ }^{6}$ aparece. O anteparo é instalado sem intencionalidade (bastou o enamoramento). A instalação se dá no momento em que não sei o que fazer, pois errei o tempo no enquadre sonoro (o vídeo com fotografias projetadas conta com uma banda

\footnotetext{
5 O conceito utilizado pela pesquisadora Maritza Farías Cerpa durante a pesquisa no CEPECA (que acompanhei) está em Chekhov. Ver: CHEKHOV, M. Para o Ator. São Paulo, Ed. Martins Fontes, 2003.

${ }^{6}$ Ver: CERPA, M. Sentido de composição na atuação em Michael Chekhov. Revistas aSPAs, Vol. 2, 2012, p 112-120.
} 
sonora com falas gravadas e intervalos de tempo fixos entre uma fala e outra; a esta banda chamei "régua sonora"). Sobra tempo. É preciso esperar a próxima marca (palavra sonorizada) para instalar o próximo o arranjo. Acabo de falar que Jorge havia cegado a namorada com um cigarro. Entre a incidência da escuta desta fala e o enquadre temporal da palavra sonorizada (que não chega), a imagem auxiliar entra em jogo e constitui nova impressão digital - que evoca uma ação inscrita na diegese: espécie de lamento diante de tamanha brutalidade.

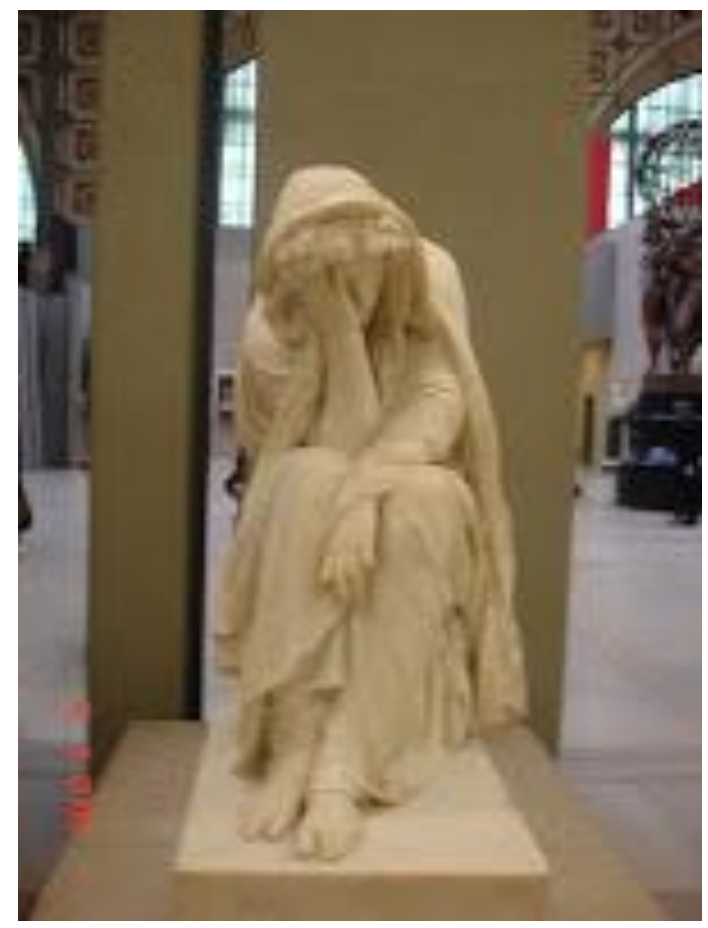

Figura 52:

Escultura de

Carpeaux

(1827-1875)

Foi assim que percebi que, entre a função da incidência e do enquadre espaçotemporal cênico, tem uma área de vulnerabilidade aberta - que é preenchida com uma impressão digital. $\mathrm{O}$ que o ator tem no seu repertório pode retornar. O anteparo-plástico molda o corpo (criando um enquadre pelo movimento) e só percebemos quando isto já aconteceu. Não se trata de uma relação cronológica entre a incidência dos materiais e a impressão em cena. Há arranjo no eixo vertical (da simultaneidade) entre as funções do enquadramento e da incidência e a brecha por onde se instala a impressão digital. Assim como há poética de enquadres, jogo de enquadres (e não um enquadre). Há arranjo entre incidência, enquadre e atualização. Mais tarde, revendo os materiais, me deparo com a escultura do Carpeaux publicada no blog. Trata-se de um gesto parecido com o de Maritza. O blog funciona como um baú de imagens. Passando os olhos por elas, depois 
do primeiro rascunho da cena, novas associações acontecem com momentos cênicos já constituídos. Há um momento, por exemplo, em que Suzana está parada com um ursinho debaixo do braço, enquanto atrás dela está a projeção da briga de um casal. Por que não o enquadramento com a imagem seguinte? Adoto-a como enquadramento.

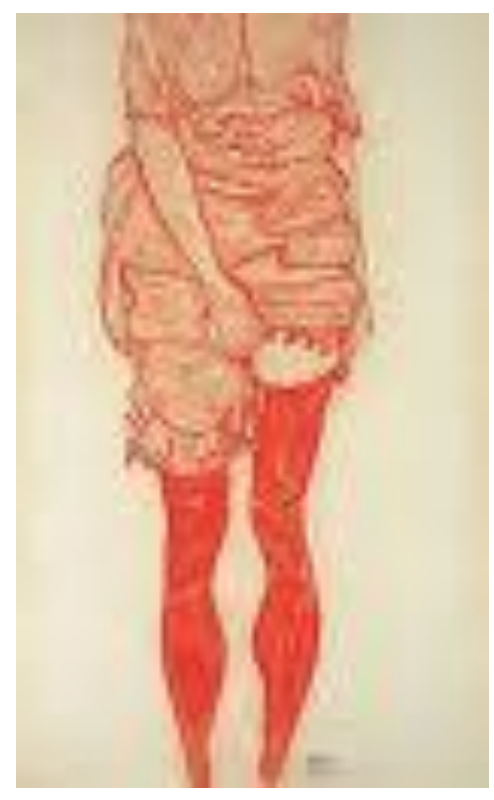

Figura 53: Standing Woman In Red (Egon Schiele, 1913)

Em sustentação (em arranjo), está o imaginário que me inclui - inclui a minha história de vida (fazendo incidência). Partimos disto: a imagem desejada articula algo do sujeito. O arranjo pode passar a contar com a regra da atualização de uma imagem destas, em certo lugar da cena, quando é nomeada no pré-jogo. Ao invés de ser treinada no enquadramento espaço-temporal é esta sua incidência (não seu enquadramento) que, em um lugar determinado da cadeia, é amarrada com a repetição do pré-jogo.

Há um deixar-se levar por atravessamentos (de materiais e suas reverberações) tanto dentro quanto fora da cena. Uma cena já constituída passa a ser um campo de extração de materiais para novos encontros. Depois da improvisação é preciso fixar o que apareceu com certo detalhamento. Sonho com as imagens. Criei story-bords para exercitar o olhar externo: desenhava o que imaginava. São várias plasticidades que se entrelaçam: a visualidade da diegese, a visualidade corporal, os arranjos externos, a sonoridade das palavras, associações com a vida, com campos de extração específicos (como a religião ou a obra rodrigueana tal como está inscrita na cultura). Na intersecção de tudo isto há uma escrita cênica - que se fixa como escrita. Como escritura, mas que depende da tessitura corporal para atualizar incidências. 


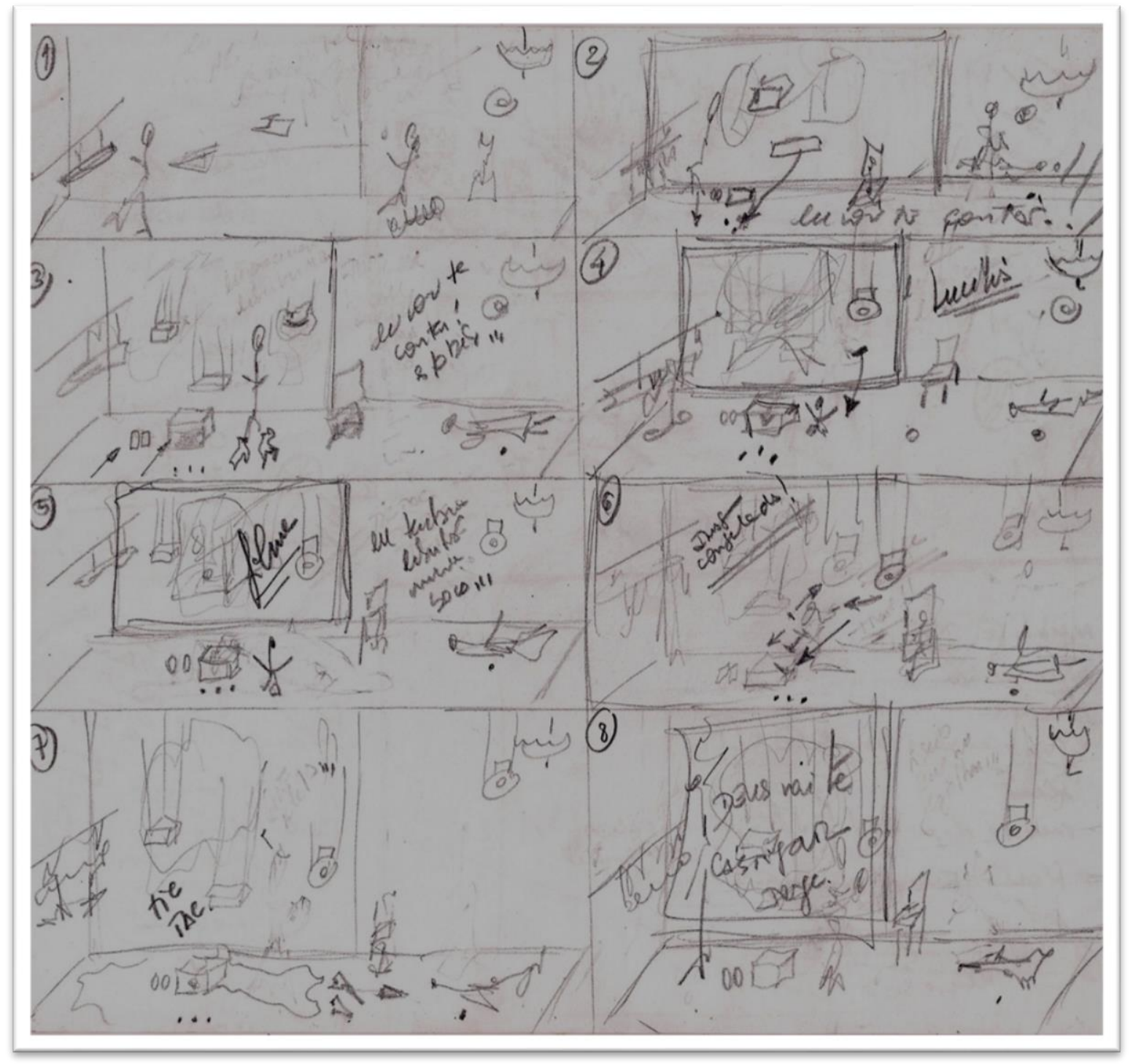

Figura 54: Story-bord da "Cena 4: O Primeiro Beijo" 


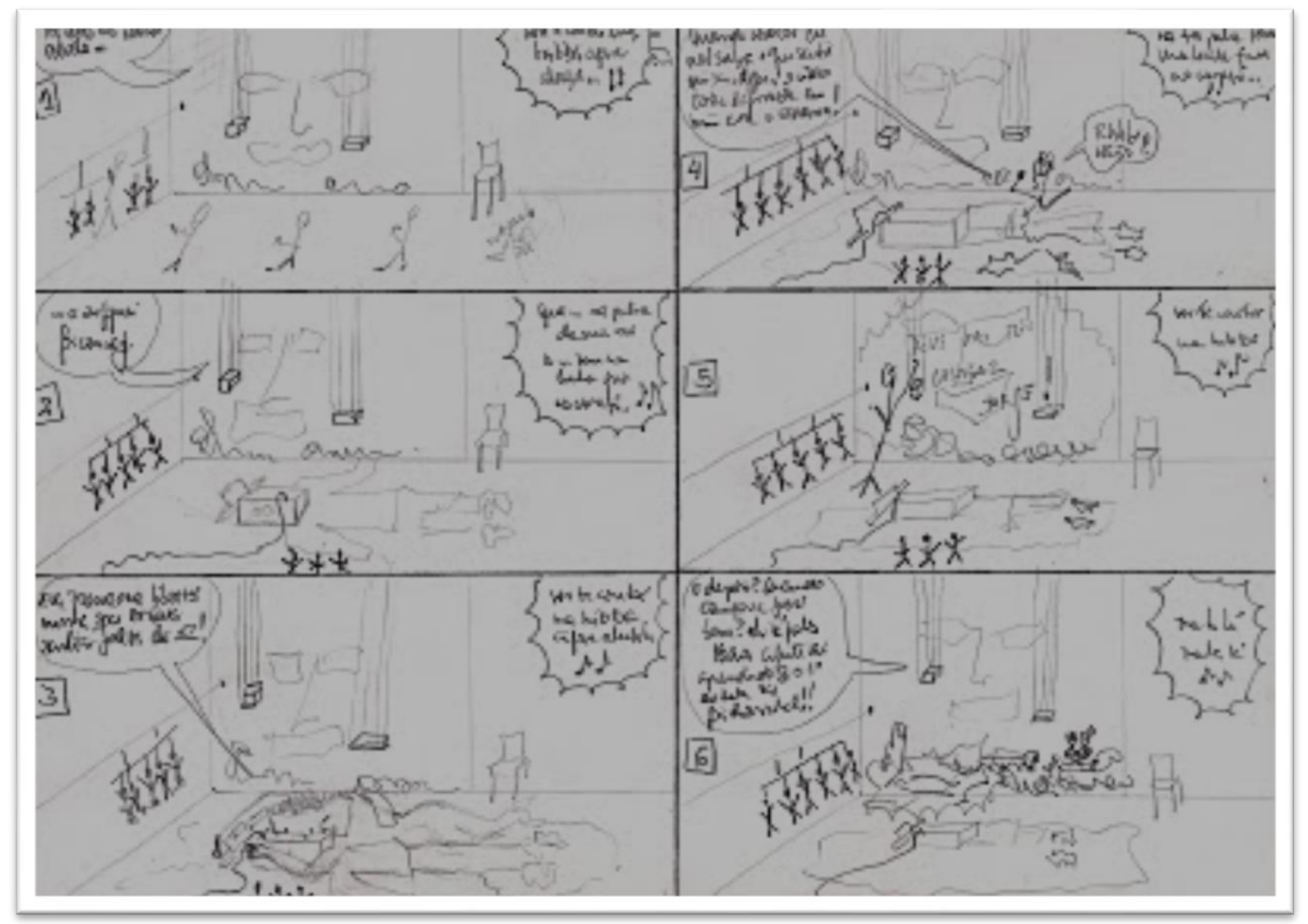

Figura 55: Story-bord da "Cena 4: O Primeiro Beijo"

\subsubsection{Entre Anteparo e Impressão Digital: Uma Reflexão}

O termo "anteparo" foi extraído da "Oficina da Essência" (Silva, 2010) onde aparece como estrutural, podendo ser de várias modalidades (palavra, som, objeto, imagem); agente de certa excitabilidade (chamada de "estímulo"), impregnada no corpo e em relação vetorial com a resultante: a inscrição, do ator, em cena. Pode-se dizer que a primeira função do anteparo é a excitabilidade. A condição para a escolha dos anteparos é a excitabilidade. Na medida em que o corpo é provocado por um anteparo que situa o foco, conta-se com a atualização de um repertório já constituído para produzir a impressão digital. A esta área, onde se atualiza reverberações impregnadas na memória corporal, chamamos de "área de vulnerabilidade". 


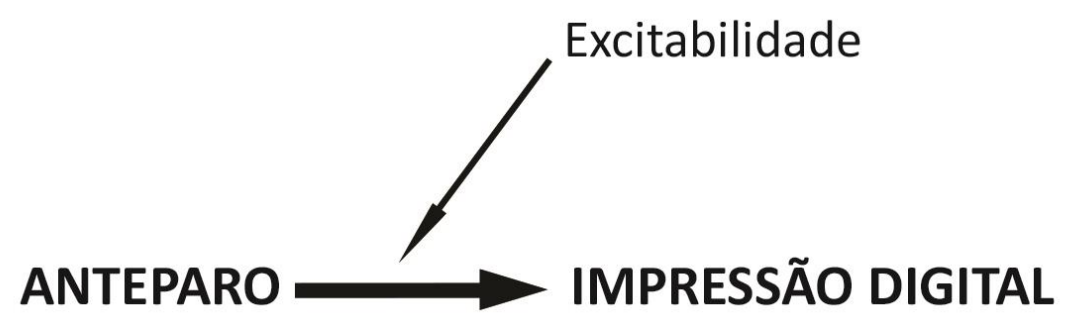

Figura 56: Entre Anteparo e Impressão Digital: A Excitabilidade

Encontra-se o termo anteparo também em outros teóricos, como Merlau-Ponty (e em comentários de Lacan sobre o seu uso em Merlau-Ponty) ${ }^{7}$. A partir de "O Visível e o Invisível", Lacan analisa, em "Outros Escritos", a relação do sujeito com a luz. O anteparo aparece (tal como em Silva) como objeto de mediação e, também, como logro (como sedução):

O logro tem aqui, portanto, uma função essencial. (...) Sem dúvida é por intermédio de máscaras que o masculino, o feminino, se encontram da maneira mais aguda, mais ardente. Só que o sujeito - o sujeito humano, o sujeito do desejo que é a essência do homem - não é de modo algum, ao contrário do animal, inteiramente preso por essa captura imaginária. Ele se demarca nela. Como? Na medida em que, ele, isola a função do anteparo, e joga com ela. $\mathrm{O}$ homem, com efeito, sabe jogar com a máscara como sendo esse mais além do que há o olhar. $\mathrm{O}$ anteparo é aqui o lugar da mediação (LACAN, 1996, p. 105).

O anteparo aparece como mediador da visão. Por fazer sombra, também faz aparecer aquilo que a luz escondia:

Se, por isolado, um efeito de iluminação nos domina, se, por exemplo, um pincel da luz que conduz nosso olho nos cativa a ponto de nos aparecer como um cone leitoso e de nos impedir de ver o que ele ilumina - só o fato de introduzir nesse campo um pequeno anteparo, que corte na direção daquilo que é iluminado sem ser visto, faz reentrar na sombra, se assim podemos dizer, a luz leitosa, e faz surgir o objeto que ela escondia (idem).

O anteparo é um objeto que, por ser opaco, deixa a luz transbordar ao seu redor:

(...) algo que representa um papel exatamente inverso, que opera, não por ser atravessável, mas, ao contrário, por ser opaco - é o anteparo, o écran. No que se apresenta a mim como espaço da luz, o que é o olhar é sempre algum jogo

\footnotetext{
7 Ver em: LACAN, J. O Seminário, Livro 11: Os quatro conceitos fundamentais da psicanálise. Rio de Janeiro, Jorge Zahar Ed, 1996.
} 
da luz com a opacidade. (...) é sempre o que me faz me conter, em cada ponto, de ser anteparo, de fazer aparecer a luz como cintilação, que o transborda. Para dizer tudo, o ponto de olhar participa sempre da ambiguidade da joia. E eu, se sou alguma coisa no quadro, é também sob essa forma de anteparo, que ainda há pouco chamei de mancha (idem, p. 95).

Lacan acaba identificando o lugar do anteparo com o sujeito elidido do quadro (neste ponto onde o anteparo se situa marcado pelo desejo): "Em consequência, e na medida em que o quadro entra numa relação com o desejo, o lugar de um anteparo central está sempre marcado, que é justamente aquilo pelo que diante do quadro, sou elidido como sujeito do plano geometral” (idem, p. 106). Encontramos em MerlauPonty, tal como na "Oficina da Essência", alusão explícita à função de proteção. Do que o anteparo protege em Merlau-Ponty? Trata-se de um pequeno objeto redondo colocado entre o olho e a luz. A função do olhar está sublinhada; função valorizada na experiência cênica do ateliê. $\mathrm{O}$ ateliê depende do olhar do espectador. Até que algo seja construído, é este olhar que invade o corpo.

No Jogo da Exposição ${ }^{8}$ de Viola Spolin, o ator se mantém, em cena, sendo observado durante um minuto. Trata-se, inicialmente, de ser olhado sem anteparos? Ou sem aqueles que, intencionalmente, colocamos entre o corpo e o olhar? Partir da hipótese do anteparo como instância estrutural significa dizer que qualquer material isolável, que se define pela sua diferença e causa excitabilidade é anteparo. Materiais que não entram intencionalmente no jogo, mas vêm de associações súbitas (como se invadissem o ator) também são anteparos. $\mathrm{O}$ que o ator lê da situação de jogo também causa excitabilidade e altera a resultante. Materiais que fazem parte do contexto de jogo provocam, aderem. $\mathrm{O}$ ator produz a partir da relação que estabelece com o processo de estar em cena diante do espectador. Anteparos se intrometem de súbito, associados e, quando se vê, o corpo sofreu a excitabilidade e a impressão digital já foi constituída.

Estes anteparos podem ser arranjados com outros, que organizam o corpo no tempo e no espaço. Por exemplo, neste jogo, quando Spolin, intencionalmente, introduz a instrução "conte as cadeiras do auditório", com este material, que situa o foco, o ator consegue sustentar uma ação no tempo. O material conduz a organização temporal na medida em que se desdobra na cadeia de imagens acústicas "um, dois, três, quatro". A voz de Spolin situa o foco que, em seguida, segue por uma sucessão de materiais isoláveis e diferenciais, encadeados, enquanto algo é atualizado corpo; algo próprio do

${ }^{8}$ SPOLIN, V. O Fichário de Viola Spolin. São Paulo: Ed. Perspectiva, 2001. 
ator, do seu repertório (experiência) e que participa da inscrição da impressão digital. Trata-se de funções. O que proponho como enquadramento é a propriedade de situar os efeitos de incidência no tempo e/ou no espaço. A área de vulnerabilidade conta com a atualização da memória corporal na medida em que o corpo é vulnerável aos ecos que naquele instante são atualizados (graças à incidência do anteparo em foco ou graças à incidência do arranjo onde este se encontra).

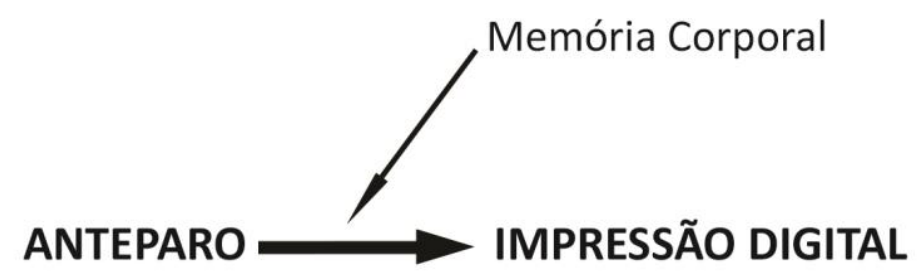

Figura 57: Entre Anteparo e Impressão Digital: Memória Corporal

Um espaço de vulnerabilidade se abre, despertando a memória corporal e seus ecos, enquanto o corpo sofre a incidência do arranjo e é organizado no espaço-tempo (enquadrado). Um material introduzido no foco altera todo o arranjo, porque provoca outras ressonâncias. Com o enquadramento, o ator está protegido do toque do olhar. Apesar de se deparar com a excitabilidade causada pelo olhar do outro lhe queimando, materiais o enquadram. Está protegido porque o olhar se volta para o enquadramento. É como se o enquadramento o vestisse. Tal como na metáfora do dedo apontado para a lua de Yoshi Oida'

Um dia Yoshi me falou a respeito de umas palavras de um velho ator de kabuki: "Posso ensinar a um jovem ator qual o movimento para apontar a lua. Porém, entre a ponta de seu dedo e a lua a responsabilidade é dele". E Yoshi acrescentou: "Quando atuo, o problema não está na beleza do meu gesto. Para mim, a questão é uma só: será que o público viu a lua?" Com Yoshi, eu vi muitas luas (BROOK, 1992, p.11)

Nos termos do ateliê, o enquadramento oferecido ao olhar é a lua que o espectador observa. A cena produzida no corpo quando a impressão digital está enquadrada é lua. É ela que deve aparecer quando encontra a sua razão de ser no olhar

\footnotetext{
9 Ator, diretor e professor integrou desde 1968 a companhia teatral de Peter Brook, em Paris. Ver OIDA, Y \& MARSCHALL, L. O Ator Invisível. São Paulo: Via Lettera, 2007 e OIDA, Yoshi. Um Ator Errante. São Paulo, Beca Produções Culturais, 1999.
} 
do outro. Encontramo-nos com a metáfora proposta por Stanislavski: o ator "vestir" o personagem - que aparece tal como uma modalidade específica de enquadramento. A lua também pode ser a ação inscrita na plasticidade do universo ficcional (que enquadra a impressão digital neste tempo e espaço outro que não o cênico); esta ação que agora o espectador enxerga, imagina, pois evocada pelo corpo. A partir do que a inscrição do corpo ou das palavras evoca, o espectador constitui imagens, associando seu repertório de vida. Há, por parte do espectador, a plasticidade do próprio olhar e mundo para pôr em cena, internamente, na medida em que esta também enquadra aquela produção do ator.

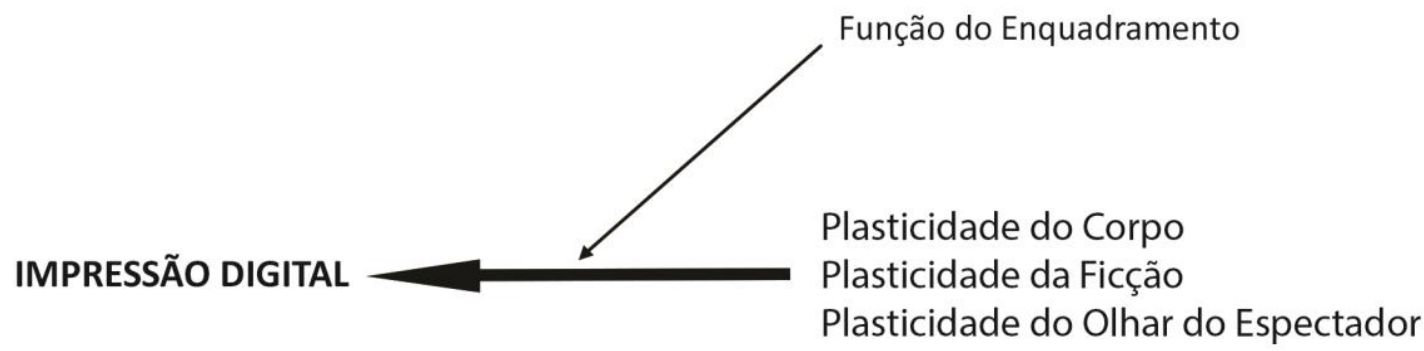

Figura 58: Função do Enquadramento

Em Silva, de qual proteção se trata? A proteção de um corpo que ainda não tem o estatuto de cênico; não possui o tratamento plástico que a inscrição na poética cênica implica. Não estamos fazendo referência aqui a um corpo necessariamente treinado. É possível constituir cenicidade com iniciantes ou não atores e elevar sua produção ao estatuto de arte. É possível jogar a cotidianidade com o enquadramento sem que o ator necessariamente tenha treinamento extra-cotidiano (apesar de testemunharmos também a importância dos treinamentos extra-cotidianos para abrir repertório que implica certas modalidades de enquadramento cênico). O que estamos defendendo é a necessidade de um arranjo que implique um jogo de enquadramento. A fala de um texto dramático pode causar excitabilidade, implicando uma identificação imediata com a ideia de ação e a imagem extraída do campo da realidade (com a sua plasticidade comum) para enquadrála. Mas, na "Oficina da Essência” (Silva, 2010), o ator utiliza a plasticidade advinda de outros campos, que transposta para a cena - como a figura extraída das artes plásticas ou um objeto, que molda, modela a impressão digital. 
Os anteparos são provocações. A própria pessoa se autoprovoca. O anteparo (é o que o Meyerhold fala) são as associações livres. Pintores, fotógrafos, eles desenham melhor o corpo no espaço. Uma cabeça da Tarsila: pode ajudar você a fazer um pescoço longo em cena... Pode servir para você desenhar o corpo. (Silva, 2012) ${ }^{10}$

Um "pescoço da Tarsila": a plasticidade do material se encontra inscrita na poética visual do corpo. Ela media a criação de uma impressão digital, oferecendo o enquadramento (organização no espaço e tempo). Assim, o ator não apenas interpreta o texto, mas atua em direção à plasticidade de um corpo modificado pela poética de um desenho: "Há de se buscar referências em quem soube desenhar o corpo" (Silva, 2012) ${ }^{11}$. Uma poética do desenho ou uma poética do estranho, oposta ao que lhe é familiar, comum. A esta mediação, Silva nomeia "triangulação": "Não tem só eu e o meu corpo. Tem eu, o meu corpo e o anteparo" (Silva, 2009) ${ }^{12}$. O anteparo media a relação entre ator e produção corporal. Ele é um “outro". É um terceiro na relação, que o excita (e pode enquadrar). Há anteparos de enquadramento que causam excitabilidade. Mas há anteparos que apenas causam excitabilidade sem enquadrar. Esta constatação implica a função do arranjo: por exemplo, um anteparo enquadra o tempo enquanto outro delimita o espaço das bordas corporais; outro faz incidência sem enquadrar; a incidência de um quarto é atualizada (enquanto eco, reverberação) na área de vulnerabilidade sem que o ator se dê conta.

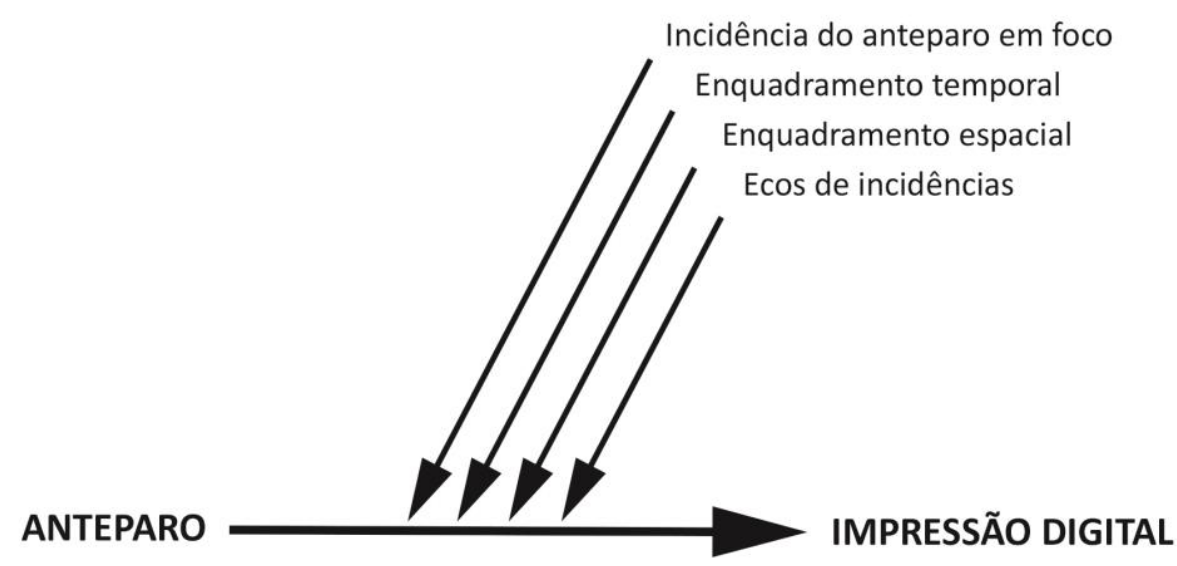

Figura 59: Entre Anteparo e Impressão Digital

\footnotetext{
${ }^{10}$ Fala extraída de debate travado em encontro do CEPECA em 15/03/2012 na sala 19 do Departamento de Artes Cênicas da Universidade de São Paulo.

${ }^{11}$ Fala extraída de debate junto a exposição no CEPECA em 10/05/2012.

${ }^{12}$ Fala extraída de debate no CEPECA pós-apresentação de pesquisadores.
} 
O trabalho com o anteparo que Silva chama "iconográfico" (a imagem extraída da obra de um pintor, uma revista, um álbum de fotografias, um filme, etc) deixa clara a função do enquadramento. Mas, outras modalidades, como a música, por exemplo, não implicam, de antemão, os limites das bordas corporais (a plasticidade do seu desenho). O desenho está livre para ser constituído com a incidência do som ou de outro material que situe o foco. Na medida em que, na área de vulnerabilidade, a memória corporal é atualizada, o arranjo conta com os ecos já impressos nesta memória. Além da incidência direta do anteparo que situa o foco, estão as incidências revividas de outros materiais. A esta ação de reviver, estou propondo o termo "atualização".

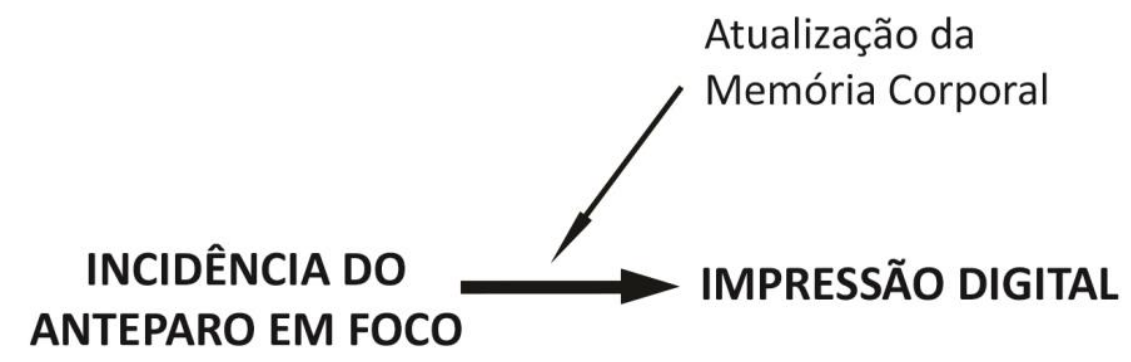

Figura 6o: Atualização da Memória Corporal

O uso de diferentes modalidades de anteparos deixa entrever uma relação, uma articulação, entre as diferentes funções: da incidência, do enquadramento e da memória corporal, que se abre. Entre a incidência do anteparo em foco e o enquadramento da impressão digital (sua organização no tempo e no espaço), existe a vulnerabilidade da memória corporal.

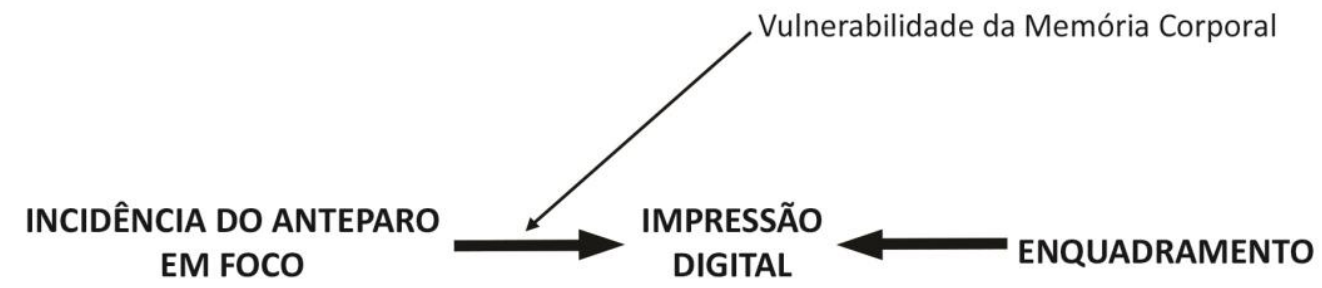

Figura 61: Vulnerabilidade da Memória Corporal 
A excitabilidade é formalizada no ateliê como função da incidência. O termo é encontrado em Lacan para o efeito da inscrição do significante (no corpo). Para Lacan o significante se articula ao gozo (no corpo).

Direi que o significante se situa no nível da substância gozante. (...) O significante é a causa do gozo. Sem o significante, como mesmo abordar aquela parte do corpo? Como, sem o significante, centrar esse algo que, do gozo, é a causa material? Por mais desmanchado, por mais confuso que isto seja, é uma parte que, do corpo, é significada nesse depósito. (...) Nisso que ele é termo, o significante é aquilo que faz alto ao gozo (LACAN, 1996, p. 36).

Este significante, estruturado com a função da linguagem, ordem do simbólico - "Por que é que damos tanta ênfase à função do significante? Porque é o fundamento da dimensão do simbólico" (idem: 32) - incide no gozo (no corpo). No ateliê, o termo incidência vem substituir o "estímulo", já disseminado na cultura teatral (termo presente na tradição de estudos sobre o trabalho do ator desde Stanislavski). Por quê? Não se trata de uma relação estímulo e resposta, tal como encontramos na medicina ou psicologia: o estímulo do órgão (que responde ao tratamento) ou a reação de fechar as pálpebras frente à ameaça de algo entrar nos olhos (estímulo). Na impressão digital, não sabemos qual será a resultante, que implica toda uma gama de contingências.

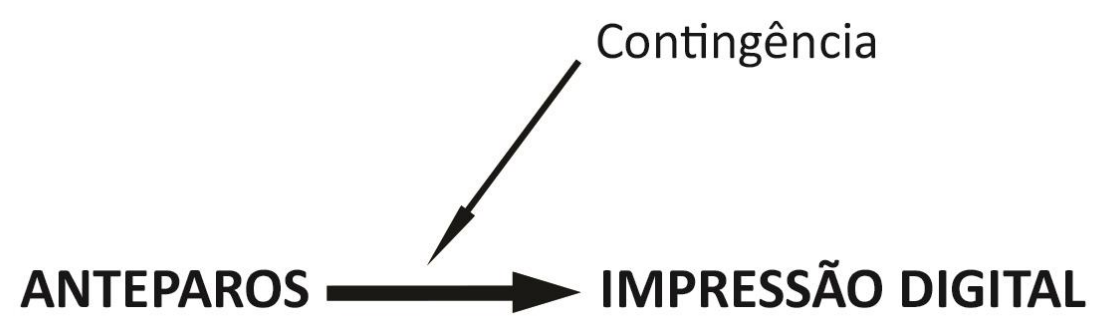

Figura 62: Entre Anteparo e Impressão Digital: Contingência

$\mathrm{Na}$ incidência, é como se o anteparo fosse acachapado no corpo, tal como uma bola de basquete é acachapada na rede: em um ponto de incidência. A sua impressão é digital porque depende e implica a singularidade e o modo de gozo daquele corpo. Cada falasser está sujeito a uma bateria específica de significantes e ao modo de gozo do corpo individual. 
(...) a substância do corpo, com a condição de que ela se defina apenas como aquilo que se goza. Propriedade do corpo vivo, sem dúvida, mas nós não sabemos o que é estar vivo, senão apenas isto, que um corpo, isso se goza. Isso só se goza por corporizá-lo de maneira significante (LACAN, 1996, p. $35)$.

O neologismo falasser refere-se à sustentação do sujeito no ser que fala. Está implicada a relação problemática com o "ter" um corpo - corpo como lugar onde o gozo se aloja (onde o significante goza). "Isso na medida em que, no sujeito que se sustenta no falasser, (...) há a capacidade de conjugar a fala e o que concerne a um certo gozo, aquele dito do falo, experimentado como parasitário, devido a essa própria fala, devido ao falasser" (LACAN, 2007, p. 55)

O falasser adora seu corpo, porque crê que o tem. Na realidade, ele não o tem, mas seu corpo é sua única consistência, consistência mental, é claro, pois seu corpo sai fora a todo instante. (...) $\mathrm{O}$ corpo decerto não se evapora $\mathrm{e}$, nesse sentido, ele é consistente, trata-se de fato constatado mesmo nos animais. É precisamente o que é antipático para a mentalidade, porque ela crê nisso, ter um corpo para adorar. É a raiz do imaginário. Eu o penso, isto é, eu o faço penso, logo eu o enssoufro (...). Em suma, é isso. É o sexual que mente lá dentro, ao ficar se relatando demais (idem, p. 64)

Segundo Jacques Alan Miler, o conceito de corpo em Lacan é diferente do conceito aristotélico de corpo. Nos seus comentários em "O Seminário, Livro 23: O Sinthoma", ele diz:

O corpo é para Aristóteles, aponta Lacan em Mais, ainda, o modelo do um. Mas esse um é o indivíduo, isto é, o um-todo-só. E cabe a Lacan interrogar então sobre a origem verdadeira do significante Um (p. 196-7; ed. fr. p. 1301). A resposta está aqui, nessa página do Sinthoma, que sugere que o corpo poderia ser o modelo, ou seja, a origem imaginária, não do um-todo-só, que é significante, marca, traço, corte, mas do um-a-mais que é o conjunto vazio. Trata-se de dizer, simplesmente, que o corpo existe como um saco de pele, vazio, fora e ao lado de seus órgãos. Acabo de escrever a palavra que permite captar do que se trata: fundar o lugar exato onde é conveniente inscrever a elucubração, central em O Anti-Édipo (G. Deleuze e F. Guatarri, Minuit, 1972; ed. Bras. Rio de Janeiro: Imago, 1976), de um "corpo sem órgãos". O corpo sem órgãos é um corpo-saco. Sua ex-sistência aos elementos que ele contém, sua consistência de continente é a do conjunto vazio na fórmula: $\{1$, Ǿ\} (MILER, 2007, p. 213-214).

Lacan trata o corpo como suporte do inconsciente na medida em que é ali que "a linguagem copula":

A psicanálise, em suma, nada mais é do que curto-circuito passando pelo sentido - o sentido como tal, definido por mim a pouco pela copulação da linguagem, posto que é a partir dela que dou suporte ao inconsciente, com nosso próprio corpo (LACAN, 2007, p. 118). 
O modo de gozo é algo irredutível; daquele corpo. No caso do ator, além de a memória corporal carregar esta especificidade, como criador, ele está sujeito às contingências dos encontros dos diferentes anteparos dentro dos arranjos; ele está sujeito aos ecos que a sua memória corporal atualiza. É como se não fosse possível escapar da especificidade da sua história, apesar de um enquadramento poder ser padronizado (uma série de atores produz impressões digitais diferentes com o mesmo enquadramento). Cada sujeito implica uma bateria de significantes próprios, da qual é efeito, mas, para além da estrutura da linguagem que o determina, para além das cadeias de significantes que atravessam o corpo, está a contingência do gozo, ordem para fora do sentido (mas que pode, com ele, se enlaçar). E estão os encontros fortuitos dos sons, que escapam ao sentido do dizível. Trata-se de atrelamento do corpo ao verbo. No verbo estão sons sem sentido; que não fazem conjunto (não estão na estrutura da linguagem). É o que Lacan chama de alíngua. Sobre a alíngua, Colette Soler diz:

Na alíngua, o significante se define pela pura diferença dos uns, sem prenderse ao sentido. Contrariamente ao simbólico, a alíngua não é um corpo, mas uma multiplicidade de diferenças que não tomou corpo. Ela não é um conjunto, não é uma estrutura, nem de linguagem, nem de discurso, pois não há ordem na alíngua. Alíngua é o nível a-estrutural do aparelho verbal, ao passo que a linguagem e o discurso são ordenações. (...) Alíngua é, antes de tudo, a integral dos equívocos possíveis que, no entanto, não fazem um todo. É que se somente há diferenças, torna-se difícil identificar os próprios elementos. O Um encarnado na alíngua, eu cito: "é algo que permanece indeciso entre o fonema, a palavra, e a frase e até mesmo o pensamento" (COLER, 2010, p. 16-17).

Uma língua, um idioma, é um depósito a partir do discurso que supõe o enlace do sentido e do gozo. Em outras palavras, é aquilo que a linguagem ordenou e veiculou de gozo num dado laço social, sempre histórico, que se deposita na alíngua (...). Poder-se-ia dizer que uma língua é emprenhada permanentemente pelo gozo que ordena a fala e seus significantes gozados. Mas um termo como "emprenhada" que evoca a vida, não cabe de forma alguma para referir-se à alíngua que é, antes de tudo, um cemitério. Traduzo assim aquilo que Lacan aponta; mesmo considerada viva, mesmo quando está em uso, uma alíngua é sempre uma língua morta. É "a morte do signo que ela veicula", o gozo depositado sendo o gozo passado ao UM do signo, ou da letra, o gozo mortificado, portanto, que se apresenta como madeira morta. Cemitério, portanto; porém, em reatualização constante, como são, aliás, os verdadeiros cemitérios. Novos signos são aí admitidos, signos que eu seria tentada a dizer excorporados a partir de experiências vitais que, passando ao verbo, secretam novas palavras, locuções, equívocos, os quais não esperam nenhum dicionário para entrar em uso (...) - e, em uso, quer dizer, uso de gozo (...). A questão, então, é de saber como a alíngua puverulenta, se posso assim dizer, multiplicidade inconsistente, inapreensível, pode se precipitar na letra, a única capaz de fixar uma identidade, identidade de gozo? Como os elementos da alíngua podem estar enganchados no corpo? (idem: 18-19). 
A alíngua numa só palavra, este neologismo de escrita, diz que a alíngua não é o idioma que o sujeito acabará por falar, mas que ela vem antes daquilo que se ouviu da fala primeira de onde ele emergiu. Lacan diz tê-la escrito numa só palavra em razão da homofonia com lalação. Lalação vem do latim "lallare", que designa o fato de cantar "lá, lá..." para adormecer as crianças, dizem os dicionários. Designa o balbucio da criança que ainda não fala, mas que já produz sons. A lalação é o som separado do sentido, mas como se sabe, entretanto, não separado do estado de contentamento. (...) A lalação evoca, em todo caso, o que da língua falada foi ouvido, antes da linguagem. Além do mais, Lacan diz em Encore: a alíngua numa palavra, isto é, a língua materna antes do significante e de antes de sua junção com o sentido. A lalação é antes canção, melodia, "água da linguagem", diz Lacan para designar o continuum fluido do que foi ouvido, que flui e de onde os elementos terminarão por se isolar, sobressair. Os efeitos dessa alíngua ultrapassam, e muito, tudo aquilo que dela podemos apreender. Esses efeitos são os afetos, no sentido em que é a alíngua que afeta primariamente o gozo. Esta tese se distingue da questão do gozo de alíngua. Que se possa gozar da matéria verbal, é algo assegurado pela existência do poeta (idem: 19).

Enquanto a impressão digital é a resultante que implica o gozo (este indizível no corpo), há os anteparos que, como significantes (materiais diferenciais, articulados) fazem eco. De maneira que, se ator dá uma resposta, como material que implica uma diferença, esta é anteparo (e a impressão digital é a resultante no corpo da incidência do arranjo onde a resposta se situa como um dos anteparos). Um significante encontra-se em relação de diferença, em cadeias verticais de possíveis substituições, sem estar impresso no eixo horizontal (em sucessão), disposto no tempo (um depois do outro). A existência de uma cadeia vertical na estrutura da linguagem implica um tempo que não é da sucessão, mas de potencialidades, de "presenças na ausência" (Sausurre, 2006) A hipótese do arranjo inclui anteparos funcionando como significantes: empilhados a um só tempo em uma cadeia vertical (tal como um acorde de notas), cuja incidência banha o corpo e atualiza a sua modalidade de gozo, a sua singularidade, o seu estilo.

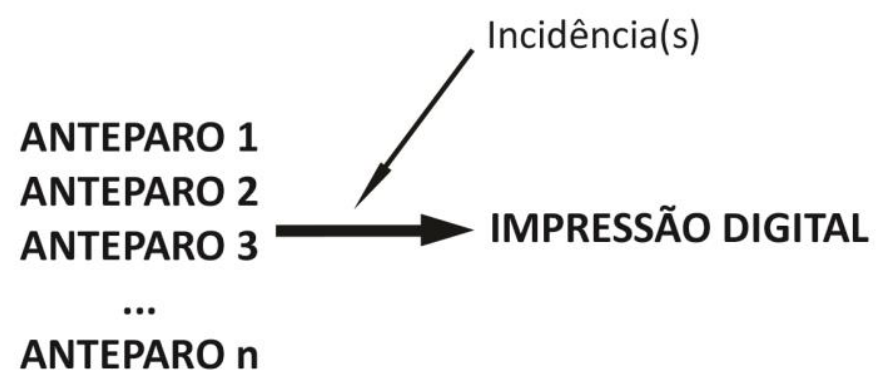

Figura 63: Empilhamento 
Uma resposta do ator à direção é um anteparo. Uma imagem colocada em jogo é um anteparo. Uma fala interna é um anteparo. Uma fala é um anteparo. Um pensamento é um anteparo. Uma instrução de jogo é um anteparo. Uma metáfora de trabalho é um anteparo. Um movimento é um anteparo. Porque o anteparo é estrutural. Se o ator dá uma reposta, esta resposta também é um anteparo. Uma impressão digital é a resultante dos efeitos de incidência de vários anteparos, junto aos ecos que transpassam a tessitura corporal e perdemos de vista. A impressão digital será sempre uma produção singular de um corpo específico (com o seu singular modo de gozo) e a contingência dos encontros nos arranjos em um instante-já, que não se repete.

Mas também há um encadeamento, deitado no tempo horizontal da cena. O que cabe no olhar? O foco desliza entre os materiais que se substituem. Agilmente, ele os recorta, como se a função do olhar fosse como uma câmera de cinema, que se abre e transita, recortando a superfície da cena. É o que se percebe na proposição de Grotowski abaixo.

(...) eu penso no canto dos olhos, a mão tem um certo ritmo, vejo minha mão com meus olhos, do lado dos meus olhos quando falo minha mão faz um certo ritmo, procuro concentrar-me e não olhar para o grande movimento de leques (referência às pessoas se abanando no auditório) e num certo ponto olho para certos rostos, isto é uma ação. Quando disse olho, identifico uma pessoa, não para vocês, mas para mim mesmo, porque eu a estou observando e me perguntando onde já a encontrei. Vejam a posição da cabeça e da mão mudou, porque fazemos uma projeção da imagem no espaço; primeiro esta pessoa aqui, onde a encontrei, em qualquer lugar a encontrei, qualquer parte do espaço e agora capto o olhar (...) ${ }^{13}$

Estes materiais isoláveis que o foco recorta são anteparos. Enquanto uma ponta do foco desliza entre eles, a outra está situada em parte da impressão digital - esta parte, que se situa no tempo-espaço cênico graças ao enquadramento. A outra parte está fora do foco. Há algo, da impressão digital, que o ator não captura com o seu olhar em cena. Há algo que não se inscreve nos elementos diferenciais da linguagem (ou nos significantes que se escuta). $\mathrm{O}$ foco é uma função da estrutura colada à impressão digital na medida em que algo dela escapa.

13 GROTOWSKI, Jerzy. Sobre o Método das Ações Físicas. Palestra no Festival de Teatro de Santo Arcangelo (Itália), jun 1988. Disponível em: http://www.grupotempo.com.br/tex grot.html (Acesso em 06/01/2013). 


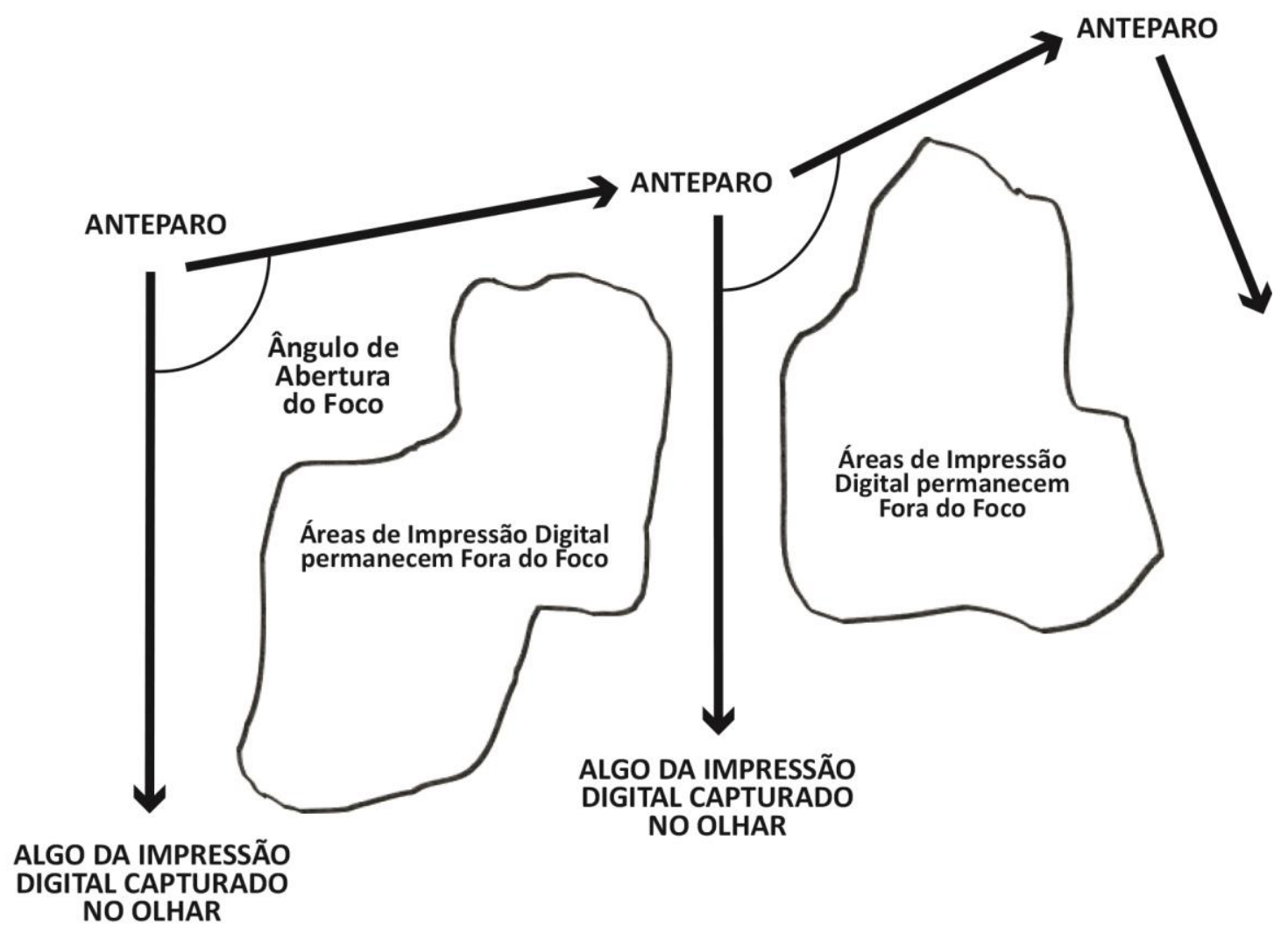

Figura 64: A "Divisão de Foco" e o "Fora de Foco"

Segundo Spolin, é quando o foco se divide que o espontâneo acontece. Ou seja, o que vem do corpo acontece na medida em que algo situou o foco: um anteparo que, com sua incidência, acorda a tessitura corporal. O corpo é atravessado pela reverberação da incidência deste anteparo, que acorda (uma analogia) a sua memória. O que não está em foco reaparece: no corpo. O foco situado no anteparo se divide: com os outros materiais, dispostos no enquadramento, bem como o pouco da impressão digital que se consegue capturar. Isolável, o que dela se recorta torna-se também anteparo. A impressão digital enquanto singularidade é inapreensível através da linguagem que recorta o real. O que interessa ao ateliê é que a incidência de um anteparo desperta ecos e atualiza o singular do corpo implicando uma malha complexa de atravessamentos. A impressão digital só implica bordas porque está enquadrada (por anteparos) no desenho resultante desta atualização. No caso da incidência do som (música, voz de instrução, fala interna ou outra modalidade), o enquadramento é configurado pela atualização de incidências de materiais outros (que não aquele que situa o foco). 
A hipótese do arranjo de anteparos ganha força a partir do testemunho da prática e, também, ao se ler a teoria do ator. Depara-se com arranjos, apesar destes não estarem nomeados deste jeito. Certas descrições da prática são como paradigmas da função do arranjo. No entanto, às vezes, é preciso revisar os termos. Ao utilizar as descrições de Stanislavski, propõe-se a substituição do termo "subconsciente" para "fora do foco". Evita-se entrar no debate sobre o inconsciente estar ou não implicado na impressão digital. A fissura entre a incidência do material em foco e o enquadramento abre uma área de vulnerabilidade onde uma memória corporal atualizada os seus ecos. Para preenchê-la, o ator conta com os efeitos de incidência (os ecos, as reverberações) que transpassam a sua tessitura corporal e que perde de vista. Acredito que este seja um modo operacional de narrar uma operação a princípio tão escorregadia! Não se foca nos atravessamentos e reverberações da memória corporal, mas se está vulnerável aos ecos da incidência dos anteparos, o que indica a possibilidade de um manejo desta área (que implica as incidências dos significantes específicos do estar em cena). A inscrição do corpo em uma poética cênica específica implica uma incidência insistente de certos significantes (como, por exemplo, "precisão"), cuja ressonância é marcada na memória corporal e atualizada fora do foco. Ao dilatar o corpo (a fim de preencher a fissura entre a incidência do material e o enquadramento) o ator conta com o que foi propositadamente fixado (e volta). É este manejo que interessa a um ateliê: marcar o corpo para que algo retorne fora do foco; escrever (no sentido de fixar, fazer retornar) incidências específicas.

Lacan apresenta a escrita como o único jeito de fixar. Fixar o enquadramento através do movimento é escrevê-lo; é criar a escrita, a grafia, uma coreografia. Com a repetição, a incidência da cadeia de movimentos pode ser escrita na memória corporal (o ator não precisa coloca-la no foco para que reapareça; aparece fora do foco porque é atualizada na tessitura corporal). No entanto, não existe apenas a coreografia, mas a grafia de materiais que não enquadram (mas cuja incidência reaparece para preencher um enquadramento no sentido de pressionar suas bordas e dilatá-lo, inchá-lo de vida ou mesmo de rompê-lo, transformá-lo). As bordas de uma partitura física podem oferecer enquadramento, ordenação, aos efeitos de incidência de todo um arranjo; mas há jogo com outros enquadramentos fazendo pressão. Na cultura teatral, vemos muitas vezes a palavra sendo tomada como oposta ao movimento - como se os dois enquadramentos disputassem a superfície do espaço-temporal da cena (ou como se a impureza de um 
deles fosse necessária para que um caiba no outro; ou para que os dois caibam em um terceiro). Deparamo-nos com a perspectiva de enquadrar um enquadramento.

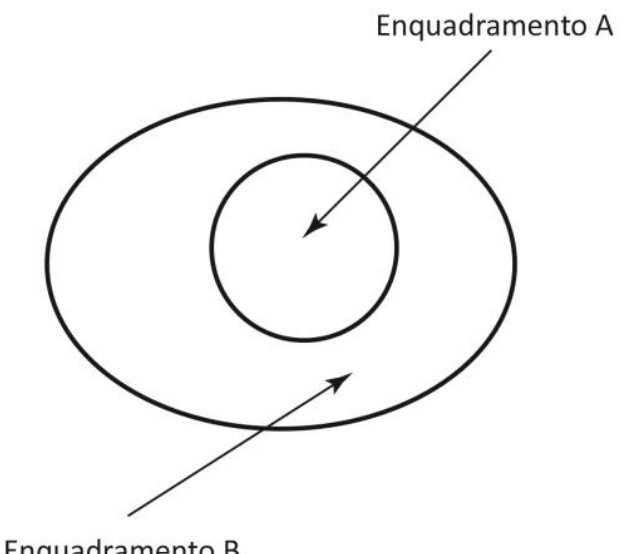

Figura 65: Enquadramento de um Enquadramento

E valendo-nos de um anteparo oculto, podemos transformar o enquadramento plástico corporal, de maneira a diluir a visualidade de um anteparo extraído das artes plásticas.

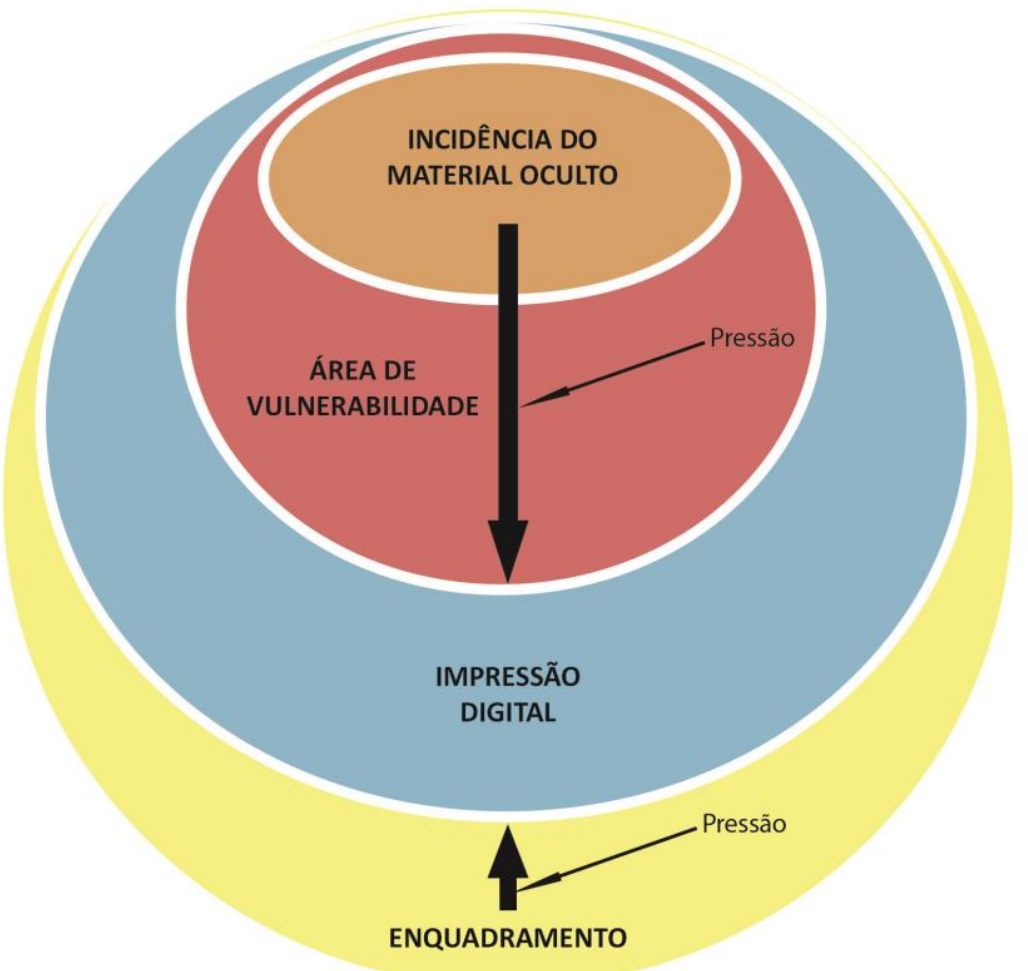

Figura 66: Pressões Opostas 
Podemos manter intacto o desenho do corpo, citando a referência; podemos fazer explícita a alusão à fonte, constituindo a impressão digital como uma citação (por exemplo, quando o movimento advindo de Pina Bausch é reconhecido) ou transformálo em uma ação tão enquadrada na ficção que o contorno original se perde. O pintor contemporâneo Glenn Brown utiliza imagens extraídas de outros (que se inscrevem, na sua criação, como materiais determinantes) - e a sua plasticidade é exposta. No entanto, a nova produção é "digital”. No caso de um pintor, a digital não está impressa e enquadrada no corpo vivo (como acontece com o ator). No caso do ator, a carne é tela que traz protuberâncias, marcas, ecos, estilo. A tendência é, na medida da incorporação, transformar, absorver, a imagem de partida. Mas podemos colocar, no arranjo, a regra de manter a sua forma.

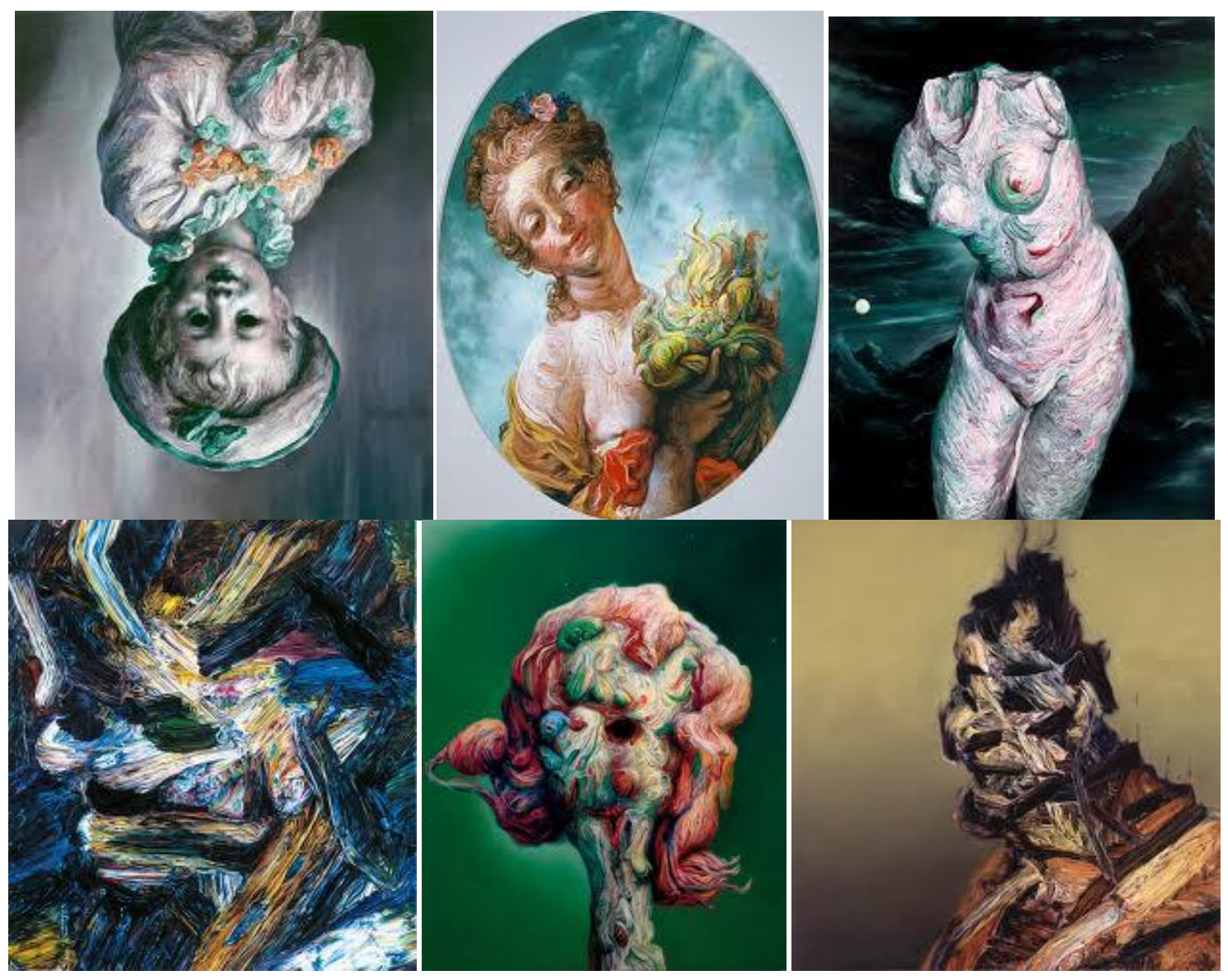

Figura 67: Obras do pintor contemporâneo Glenn Brown

Como olhar para uma imagem abstrata sem associar algo? Uma ação pode ser evocada a partir da leitura de um corpo carregado de abstração principalmente se outro 
material com qualquer tipo de construção fabular está em jogo (pois o utilizamos para enquadrar a produção corporal com nosso imaginário) ou fantasia.

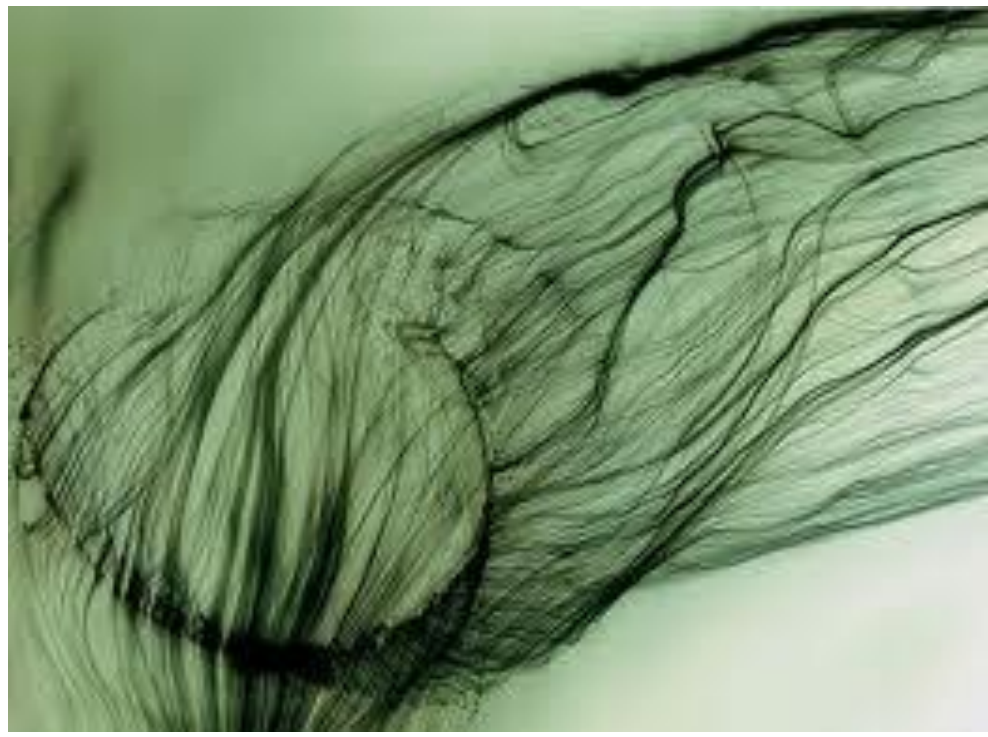

Figura 68:

Freischwimmer 16 (Wolfgang Tillmans, 2003)

\section{É na relação com uma incidência que alguma coisa pode entrar na fissura entre}

esta e o enquadramento (mesmo que este esteja, apenas, determinado pelo espaço da cena). Algo que podemos inscrever, no corpo, a anteriori, com exercícios, pode se intrometer também. Em Stanislavski, o treinamento acaba por formar uma "segunda pele" - termo utilizado por Barba a respeito do corpo extra-cotidiano (que se treina) e por Adler em relação ao registro corporal da cotidianidade (que se treina).

Diz respeito ao modo pelo qual cada ator reinventa seu próprio corpo para tornar possível o exercício da linguagem teatral. Fundamentalmente, refere-se a uma transformação psicofísica, que torna possível a experiência da vida cênica. A expressão "segunda natureza" (Ruffini, 2007), cunhada pelo diretor russo Constantin Stanislavski, diz respeito à forma pela qual o ator precisa reaprender as ações que aprendeu no seu cotidiano, de modo a construir outra "natureza corporal". Esse ato, por sua vez, torna possível tanto a criação da obra teatral quanto uma transformação radical do sujeito que investe nessa formação, posto que mobiliza diretamente o modo como aprendeu a utilizar seu corpo no cotidiano. Assim, ao reportar a cena às leis da natureza, o objetivo do Sistema de Stanislavski era o de criar para o homem em cena a ideia de uma "segunda natureza". O autor fala em natureza porque o ator em condições criativas não seria diferente do homem no meio "natural" (no cotidiano), mas acrescenta o adjetivo segunda porque, em cena, a natureza deve ser reconstruída através do trabalho sobre si mesmo (Ruffini, 2007, p. 39, tradução nossa). É possível dizer que a segunda natureza seria a capacidade de tornar real um evento fictício, visto que a reação a um evento (dito) real seria garantida pela primeira natureza (Ruffini, 2007, p. 39). Para Stanislavski (2007), na assim denominada vida real, acredita-se em algo simplesmente por ser verdadeiro; porém, de acordo com seu modo de praticar o teatro, uma coisa torna-se verdadeira porque se crê nela. Eis aqui plasmado mais um traço sobre o fictício que interessa na composição desta discussão: a 
ficção como algo que se torna verdadeiro por força da crença que se tem nela. Outra contribuição importante, sobretudo no campo da teorização teatral, é o modo como os autores Barba e Savarese (1995) pensaram e nomearam a criação que o ator faz sobre seu corpo, de modo a reinventá-lo na e para a prática teatral: corpo fictício. Na perspectiva desses autores, um corpo fictício é um corpo erigido a partir de princípios pré-expressivos. Para eles, tais princípios são noções que embasam a "vida do ator-bailarino" (1995, p. 18). Entretanto, esses princípios não se relacionam somente com a fisiologia e a mecânica do corpo. Eles estão baseados numa rede de ficções, mas ficções que lidam com forças físicas que movem o corpo. O que diferencia a busca de um corpo fictício de uma personalidade fictícia - mais coerente com a proposição stanislavskiana na fase inicial do seu trabalho - o fato de que a segunda possibilidade, que é também a mais tradicional na prática teatral euro-americana, está calcada em ficções que lidam com a psicologia, o comportamento e a história da personagem representada pelo ator. Por outro lado, a busca por um corpo fictício é, antes de tudo, a necessidade de romper com as respostas automáticas do comportamento cotidiano. Para tanto, é necessário que o ator aprenda a fazer usos do seu corpo diferentemente do uso cotidiano; faz-se necessário constituir outra linguagem corporal que possibilite ao ator expressar-se diferentemente da sua forma usual. Trata-se de uma transformação, a um só tempo, física e mental, de aprender a agir de outra forma, agora numa perspectiva não cotidiana. Esse universo corporal (não cotidiano, extracotidiano, fictício, cênico, como queiramos nomeá-lo) que o ator faz aflorar no seu corpo por meio do trabalho teatral não está apartado da sua dimensão cotidiana, prosaica; é ainda o mesmo corpo se fazendo e desfazendo - tal qual um ator ao entrar e sair de cena - por meio dessas múltiplas e, ao mesmo tempo, particulares dimensões do seu próprio corpo. (ALCÂNTARA, 2013, p. 909-910)

Considera-se o registro do corpo cotidiano algo que pode se instalar na fissura entre os enquadramentos e as incidências que situam o foco. É preciso anteparos para impregnar o corpo de cotidianidade, porque se não há anteparos, o ator se depara com o vazio e paralisa; se não há anteparos, não há como introduzir algo no corpo; não há como trabalhar qualquer tipo de cenicidade (seja implicando plasticidade estranhada ou cotidiana, íntima). Nos dois casos, há uma produção que pressiona os materiais externos plástico-corporais, causando pequenas (ou grandes) variações.

Uma imagem abstrata das artes plásticas pode ser enquadrada com a fantasia constituída em leitura. O mesmo pode acontecer com a abstração corporal: ela evoca imagens que situam a impressão digital constituída, mesmo que não se trate de uma construção imaginária unificada por uma fábula. A ação é evocada a partir do corpo (afetado) e impresso (digital). É o que acontece com treinamentos de ações físicas barbianos ${ }^{14}$. Começa-se pela inscrição de abstração: movimentos de puxar, lançar e empurrar que, encadeados, constituem uma coreografia abstrata. Este princípio abre possibilidades de jogo com frases - já que podem entrar como auxiliares da constituição das ações. O que resta à ideia da ação? Há o desenho corporal de enquadramento. Há

14 Em treinamentos com a Profa Dra. Elizabeth Lopes (encenadora e professora do Departamento de Artes Cênicas da USP) e Jan Ferslev (ator do Odin Teatret, companhia de Eugênio Barba). 
jogo, uma poética de enquadres: tanto a fantasia (que situa a ação) quanto o movimento que escapa a este imaginário e bordeia, limitam a digital. Há espaço entre os enquadres, diferenças. Há um arranjo, composição com os enquadres diferentes.

Uma terceira possibilidade é escolher imagens em correspondência direta com a ação, justamente por evocá-la. Neste caso, há uma coincidência entre a ação que a imagem evoca e a sua leitura. No entanto, se escuta também outros significantes, pois a impressão digital não se limita a ação evocada. Quando trabalhamos com o texto dramático, as ações são construídas nas suas entrelinhas. Com o texto narrativo, ações estão evocadas na fala. Então, é quase como montar uma história em quadrinhos para enquadrar. Neste caso, o nome da imagem vai para o pré-jogo e são criadas falas internas para que a sua incidência transforme o desenho já determinado.

Todo enquadramento implica uma plasticidade e as suas bordas, os seus limites. A dramaturgia performativa valoriza a plasticidade de um eixo extra-ficcional, onde o contexto de realização da obra é tematizado. Ainda assim, há um imaginário implicado: o contexto do ator; o sentido da sua relação com o ato cênico. Trata-se da imagem de um eu em relação ao outro; mundo, direção, público, processo (em Lacan a imagem de um eu em relação a outros implica a ordem do imaginário, com as suas relações duais de identificação).

A plasticidade do cotidiano também se estabelece como enquadramento quando o jogo implica atividades cotidianas, como abrir a porta ou acender uma lareira; calçar a sandália (sucessão de atividades para realizar). Dentro deste enquadramento, as circunstâncias imaginárias permanecem em ebulição. Plástico, o imaginário é bordado conforme novas associações aparecem. Dizer que a alma se mexe por dentro dos enquadramentos fixos seria uma metáfora que talvez seja ilustrativa.

\footnotetext{
Suponhamos que um ator tenha perfeito domínio das suas faculdades em cena. Sua disposição é tão completa que ele é capaz de dissecar os elementos que a compõem, sem sair do seu personagem. Então todos funcionando bem, facilitando o funcionamento recíproco. Surge, então, uma breve discrepância. $\mathrm{O}$ ator logo investiga, para ver qual é a parte que não está em ordem. Descobre o erro e corrige. E, entretanto, o tempo todo, consegue facilmente continuar interpretando seu papel, mesmo quando se observa a si mesmo. (STANISLAVSKI, 1989, p. 281).
}

O enquadramento não está morto, ele também se mexe. Há um jogo de deixarse levar pelo fluxo de incidências de um enquadramento que se instala na área de vulnerabilidade, de maneira que a imagem da ação física pré-determinada não situa o 
foco, mas algo novo que se captura da impressão digital (a cada instante) divide o foco. Existe um jogo entre enquadramento e a instalação pulsional. Um jogo de manipulação do foco, quando o ator se instiga com uma imagem acústica - que pode ser a regra de jogo (da precisão ou da dilatação do tempo) ou um dado da ficção. Pode, também, ser algo que se anuncia como voz da personagem; e configura uma modalidade específica de arranjo. O jogo é vivido em nome próprio. No jogo dramático, trata-se de disfarçá-lo com a plasticidade da personagem (inscrevendo as resultantes corporais em cadeias que constroem a plasticidade da diegese). Constrói-se uma partitura de enquadramentos. A escuta implica significantes que, por sua vez, evocam a diegese, cuja plasticidade enquadra a resultante cênica.

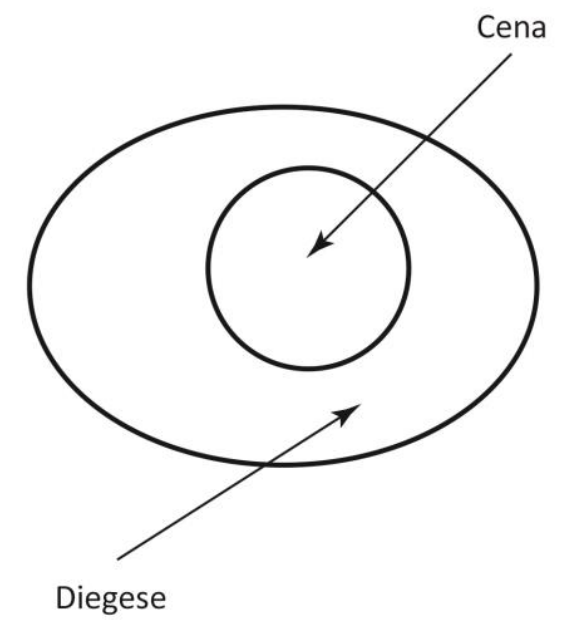

Figura 69: Cena Enquadrada pela Diegese

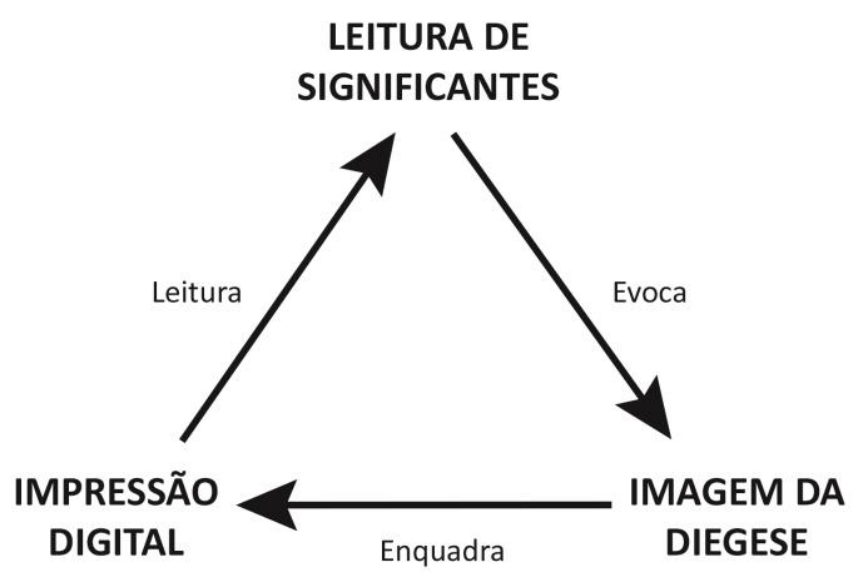

Figura 7o: Escuta em Cena 
O mundo ficcional é plástico. Ele se modifica com o ato de ver novas imagens. Muitas vezes, quando, no ateliê, trabalhamos com o texto dramático, uma figura extraída das artes plásticas (ou outro campo) vem de encontro com as palavras e, junto a ela, evoca uma ação. A pulsão do olhar está em jogo: ver o que não tínhamos visto. Os materiais, articulados, constroem efeitos de ação para o texto.

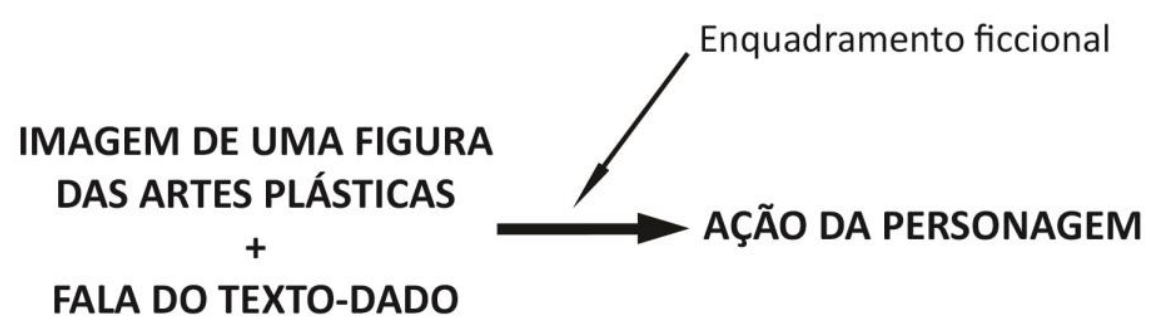

Figura 71: Enquadramento Ficcional

A visualização da ação que enquadra a fala implica uma organização em um tempo e um espaço outro: ficcional - e a plasticidade (a propriedade de transformação) das imagens que estão dentro daquelas bordas (e podem alarga-la). $\mathrm{O}$ encontro entre a imagem das artes plásticas com a palavra do texto constitui-se como um jogo de enquadramento específico: a impressão digital é situada, enquadrada, neste outro espaço-tempo: a diegese. Um enquadramento fora do espaço cênico, produzido em imaginação, que poderia ser evocado com uma palavra proferida na mesa de um bar, mas é evocado com um corpo em cena. Assim, a imagem da impressão digital é inscrita na cadeia da ficção - e entra em relação com as palavras que se inscrevem nesta mesma cadeia. Mas o desenho corpo, como o ator situa o seu corpo no tempo e espaço cênico, é outro enquadramento; possui plasticidade (capacidade de transformação) e limites. A poética da ficção (onde se situa a ação que pode ser escutada) implica uma modalidade específica, com sua plasticidade. A plasticidade do corpo e da ficção podem se articular conforme o arranjo; e se opor conforme o arranjo. 


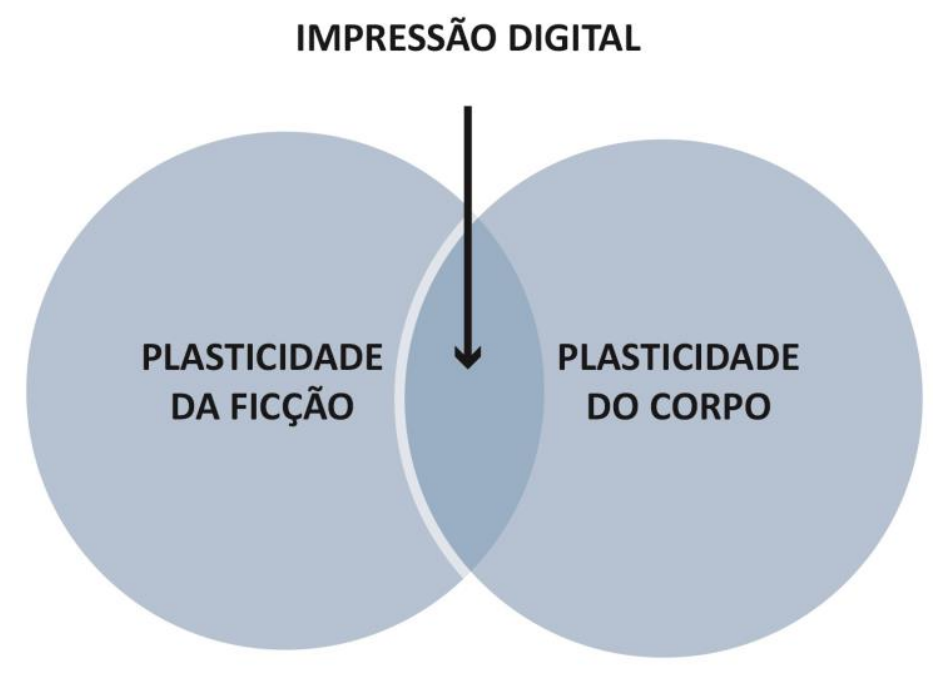

Figura 72: Impressão Digital

Há jogo entre dois enquadramentos, portanto; composição. $\mathrm{O}$ ator enquadra a fala em determinado tempo e espaço ficcionais. No entanto, a plasticidade da voz resta à plasticidade deste enquadramento. Há poéticas que privilegiam certas modalidades de enquadramento: não se utilizam da plasticidade da ficção, mas abusam da plasticidade da abstração do movimento (por exemplo).

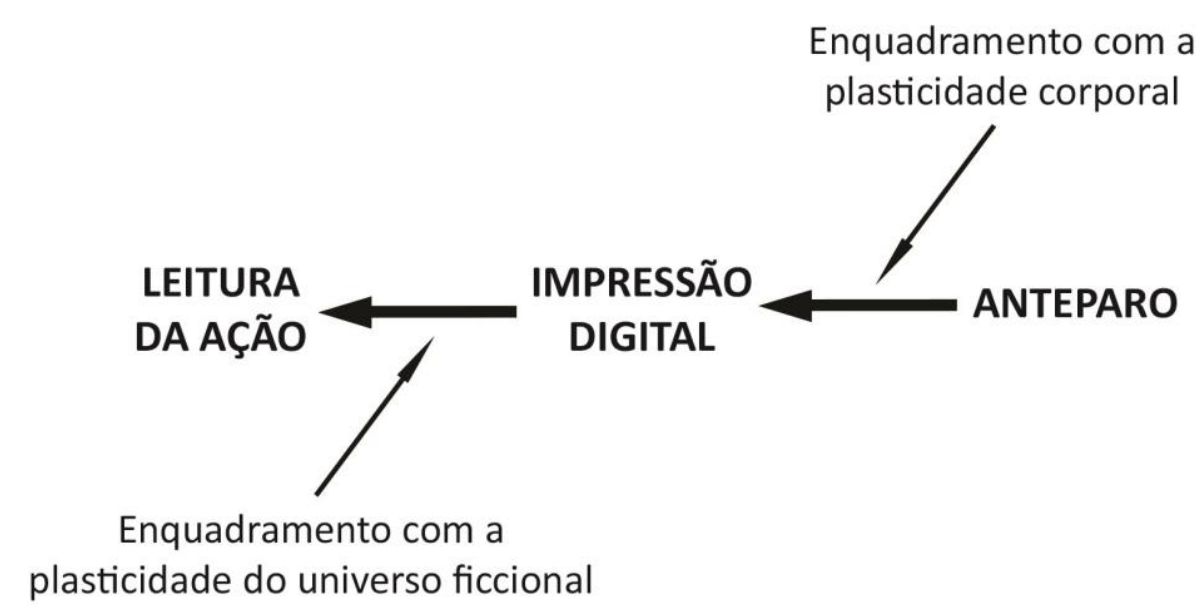

Figura 73: Plasticidade Corporal e Diegese

Não necessariamente as imagens extraídas das artes plásticas precisam ser figurativas. Uma imagem abstrata (um quadro no Pollock, por exemplo) - como se cria 
impressão digital a partir dela? Ao incorporá-la, o desenho do corpo (que encarnou esta imagem) evoca uma ação. Uma ação que pode ser evocada tanto no primeiro olhar para a imagem quanto na escuta do desenho resultante da sua incorporação.

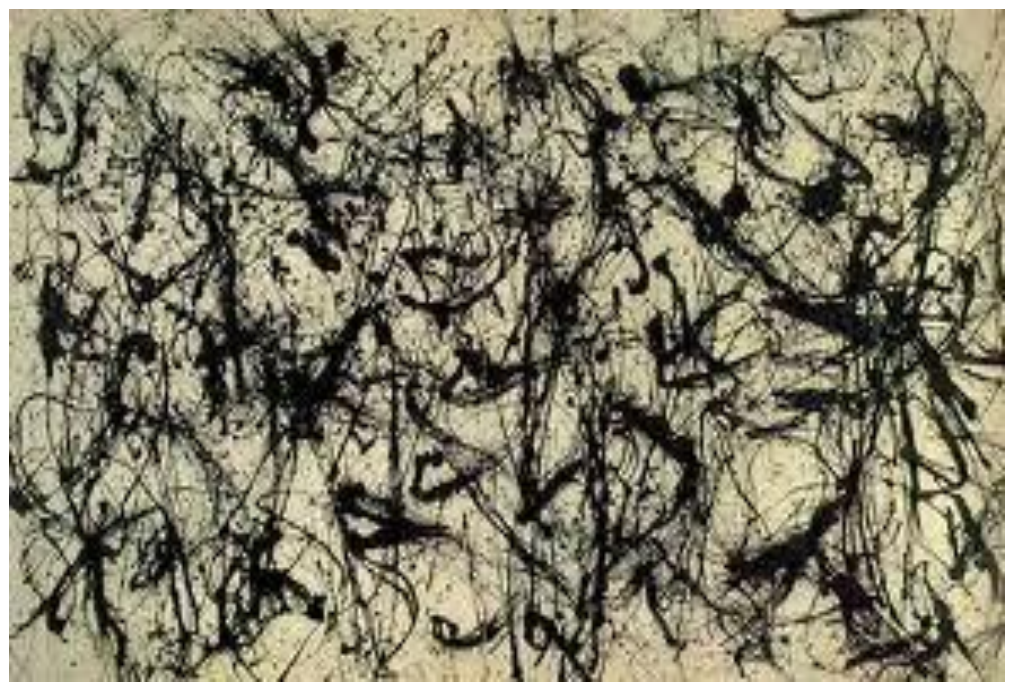

Figura 74: Jackson Pollock: Number 32,1950

Quando se instalam nas impressões digitais, estas imagens configuram um enquadramento plástico-corporal cuja visualidade é filtrada: ela se transforma. No processo de incorporação, ao se evocar uma ação, aquela abstração anterior é absorvida. Surge a visualidade da situação (da relação, do endereçamento).

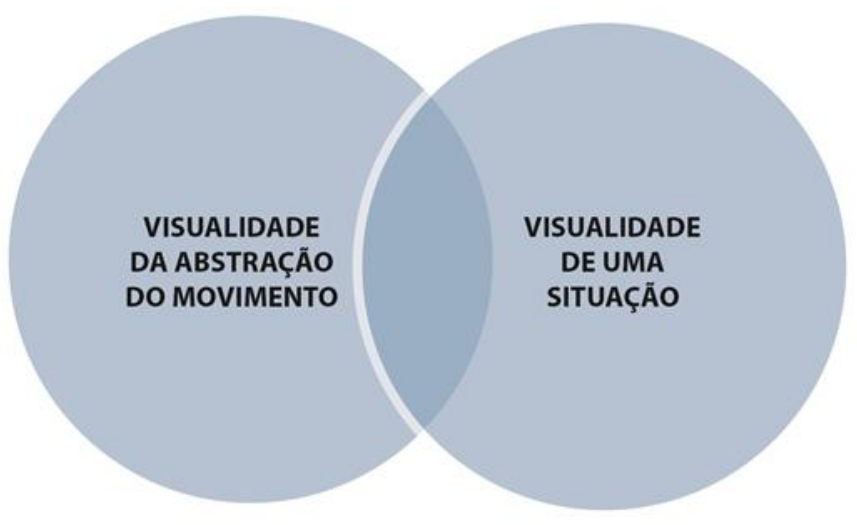

Figura 75: Abstração de um Movimento e Situação 
Por exemplo, uma mulher sentada em um café. $\mathrm{Na}$ imagem abaixo, está implicada a visualidade da ação inscrita naquela situação que a pintura evoca (mas que poderia ser evocada de outra maneira, inclusive por palavras).

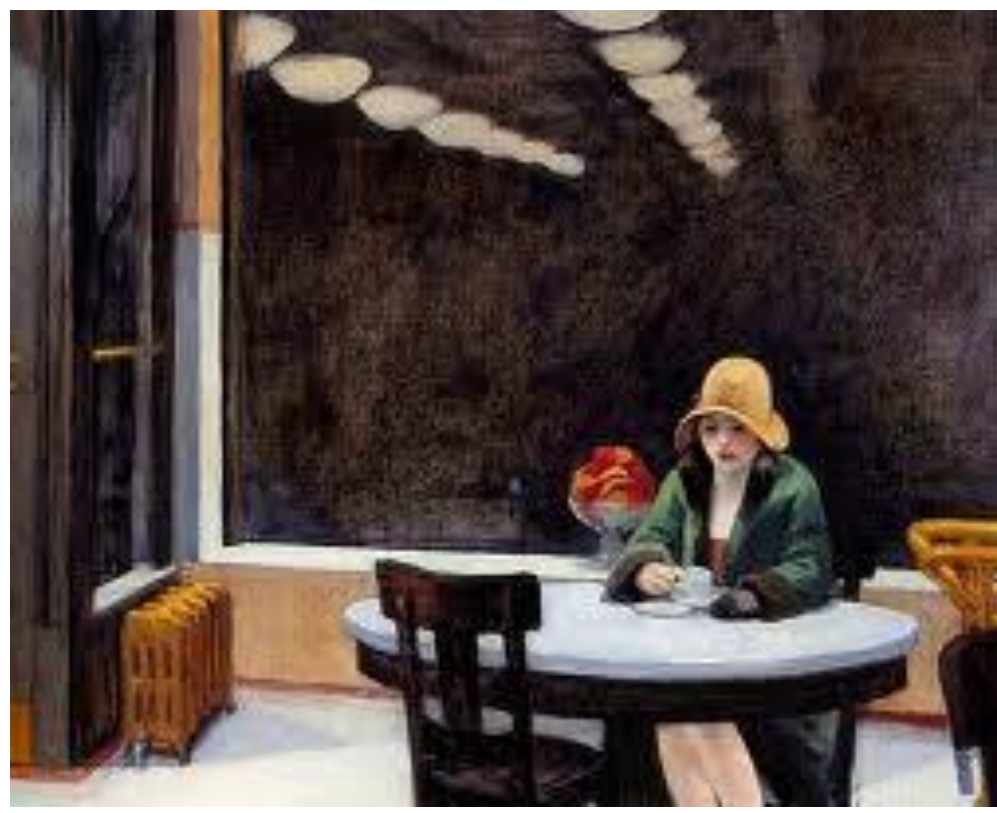

Figura 76:

Edward Hopper

- Automat, 1927

A visualidade plástica da tessitura daquela pintura é específica e diferente da visualidade das ações que ela pode evocar. Há cenas onde a plasticidade do corpo se desprende completamente da visualidade de uma ação (que pode ser evocada de muitas outras maneiras). Em algumas peças de Bob Wilson, o desenho do corpo nada tem a ver com as ações que as falas evocam - causando uma dijunção entre as duas camadas.
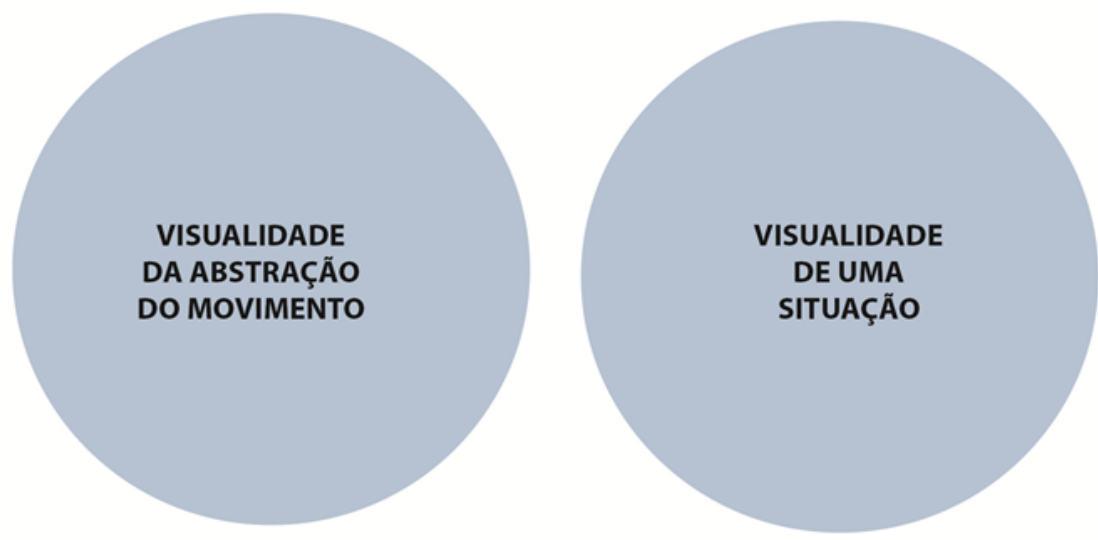

Figura 77: Abstração de um Movimento e Situação 
A pintura do corpo na cena evoca associações que podem articular uma fabula ou dela se distanciar, implicando outras camadas de associações. A parte da plasticidade corporal que não encontra o enquadramento da situação pode implicar estranhamento. $\mathrm{O}$ mesmo acontece com a sonoridade da voz e a palavra.

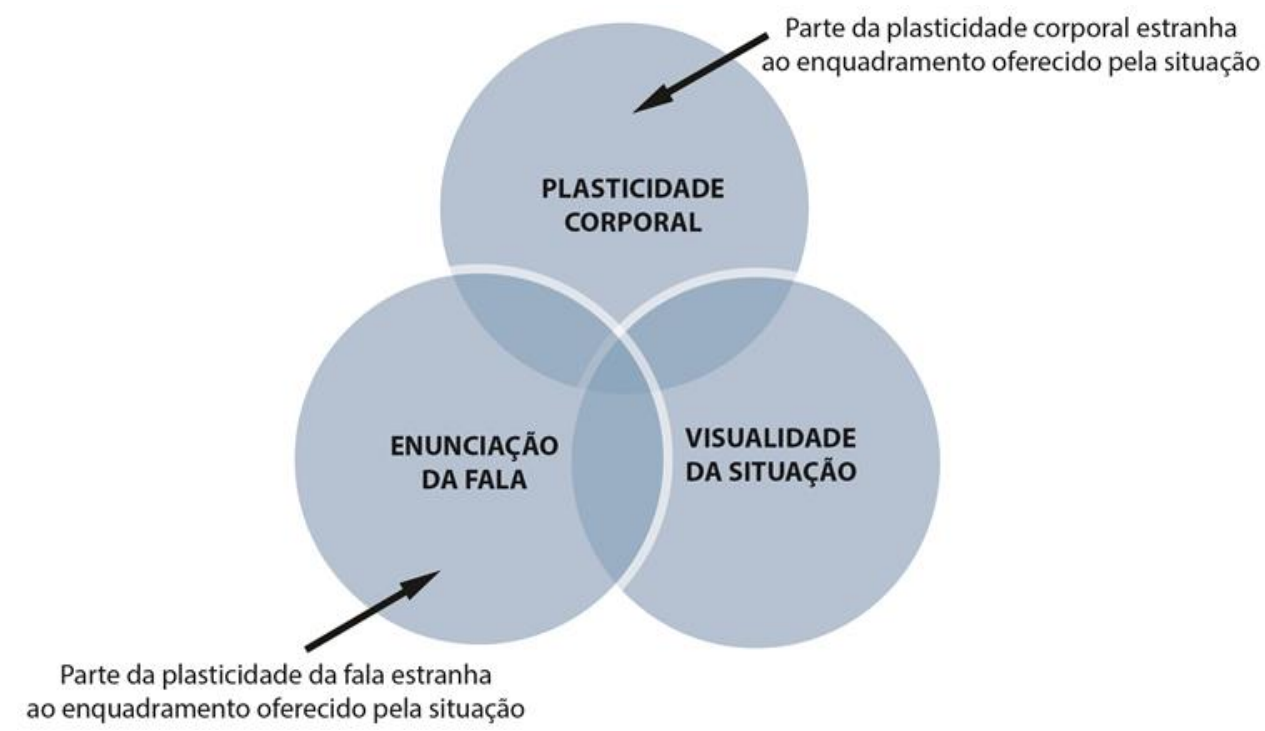

Figura 78: Plasticidade que Estranha

A operação de absorção da abstração do movimento na visualidade de uma ação implica gradações. Há poéticas que contam com uma absorção intensa, quase total, de maneira que a visualidade da situação encobre a abstração, implicando o que se nomeia "mimese da realidade".

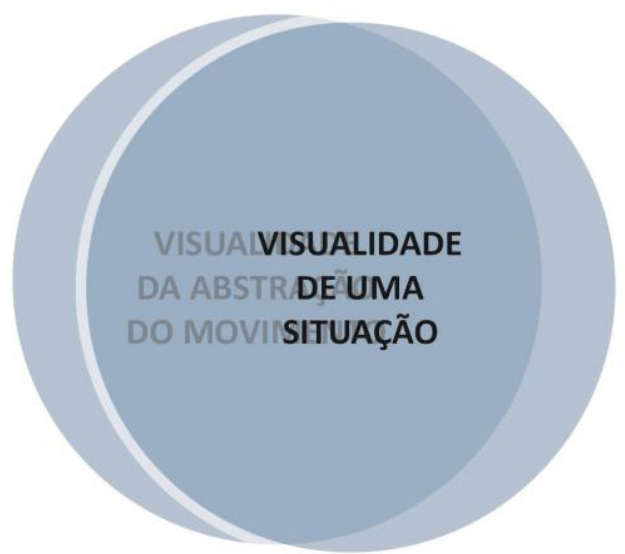

Figura 79: Visualidade do Movimento Absorvida na Situação 
Uma atividade perfeitamente inscrita na visualidade do cotidiano, como cortar cebolas, estender uma toalha ou acender a lareira (para citar exemplos que aparecem em Stanislavski), também pode ser utilizada como um enquadramento plástico-corporal. A plasticidade corporal e a plasticidade ficcional implicam camadas diferentes e evocam associações diferentes (há jogo entre elas). Abre-se um campo de experimentação para a inscrição do corpo em uma poética da cena e se observa uma necessidade de se criar repertório para que sejam atualizados durante o jogo com os outros enquadramentos.

\subsection{O Ateliê de um Pensamento}

O que procurei, principalmente, foi ser a consciência do roubo cujo poema escrevo (Jean Genet)

\subsubsection{Relação de Horizontalidade e Verticalidade nos Arranjos: "A Morte dos Pais"}

A inscrição da cadeia de impressões digitais no eixo horizontal do espetáculo depende das sucessivas trocas dos materiais que as enquadram (a cada troca do material outra impressão digital se configura). Mas também depende das sucessivas trocas entre falas internas (que implicam os impulsos de destruição destas formas). No eixo vertical, estão materiais ocultos. Anteparos das artes plásticas e falas internas são incorporados para a criação das formas e, também, para a dilatação e deformação do seu desenho. O desenho limita, oferece bordas aos efeitos de incidência destes anteparos ocultos.

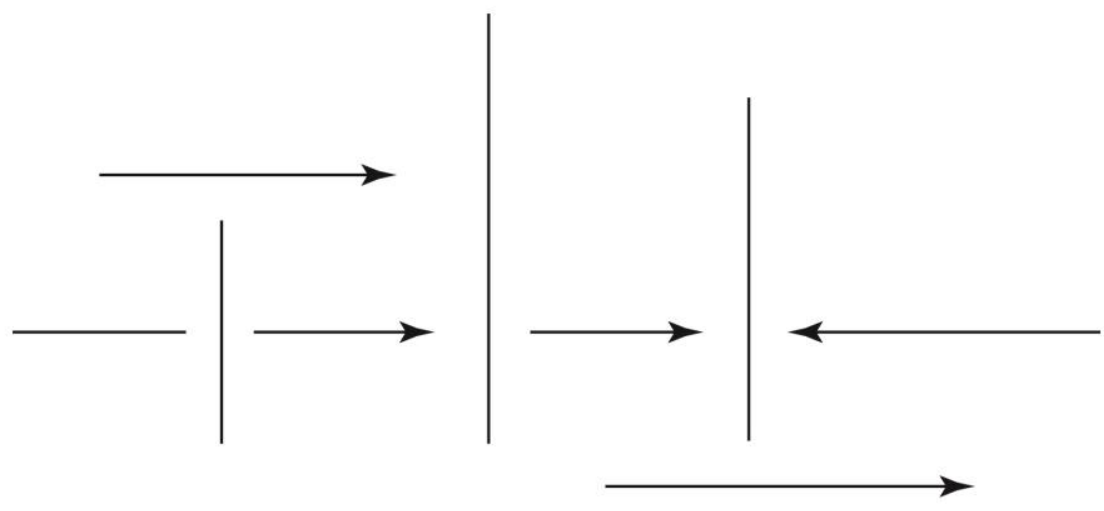

Figura 80: Várias incidências atuando em um mesmo arranjo 
Tal como as notas musicais de um acorde (na pauta musical), os materiais são harmônicos ou dissonantes. O tema do limite da forma está presente. Algumas vezes me deparo com a necessidade de uma "poética da precisão", que conta com certa autonomia em relação à ação que evoca e implica uma tradição teatral afirmada durante o século XX (a fim e com os projetos de Craig, Meyerhod, Brecht, Kantor, Wilson); em outros momentos me deparo com a necessidade de uma poética de um corpo "sujo", cotidiano, solto, íntimo. Mas enquadrado pela fala, relação ou outro (é preciso enquadramento).

Trato de imprimir, na tessitura do espetáculo, o processo - e sonorizo os nomes dos anteparos, veiculando-os em cena. Eles me garantem um tipo de estranhamento. A presença de voz sonorizada implica estranhamento: por se tratar de outro registro vocal, mas, também, por se tratar de outro texto, estranho à ficção. Este texto, no entanto, pode evocar a relação da escritora com a voz. À sucessão de falas sonorizadas chamei "régua sonora". Ela regula os tempos de reverberação de cada acorde na tessitura corporal. Ela implica intervalos fixos. Dentro de cada intervalo tenho a liberdade do improviso. $\mathrm{Na}$ próxima marca, preciso passar ao próximo foco, que desencadeará outras reverberações.
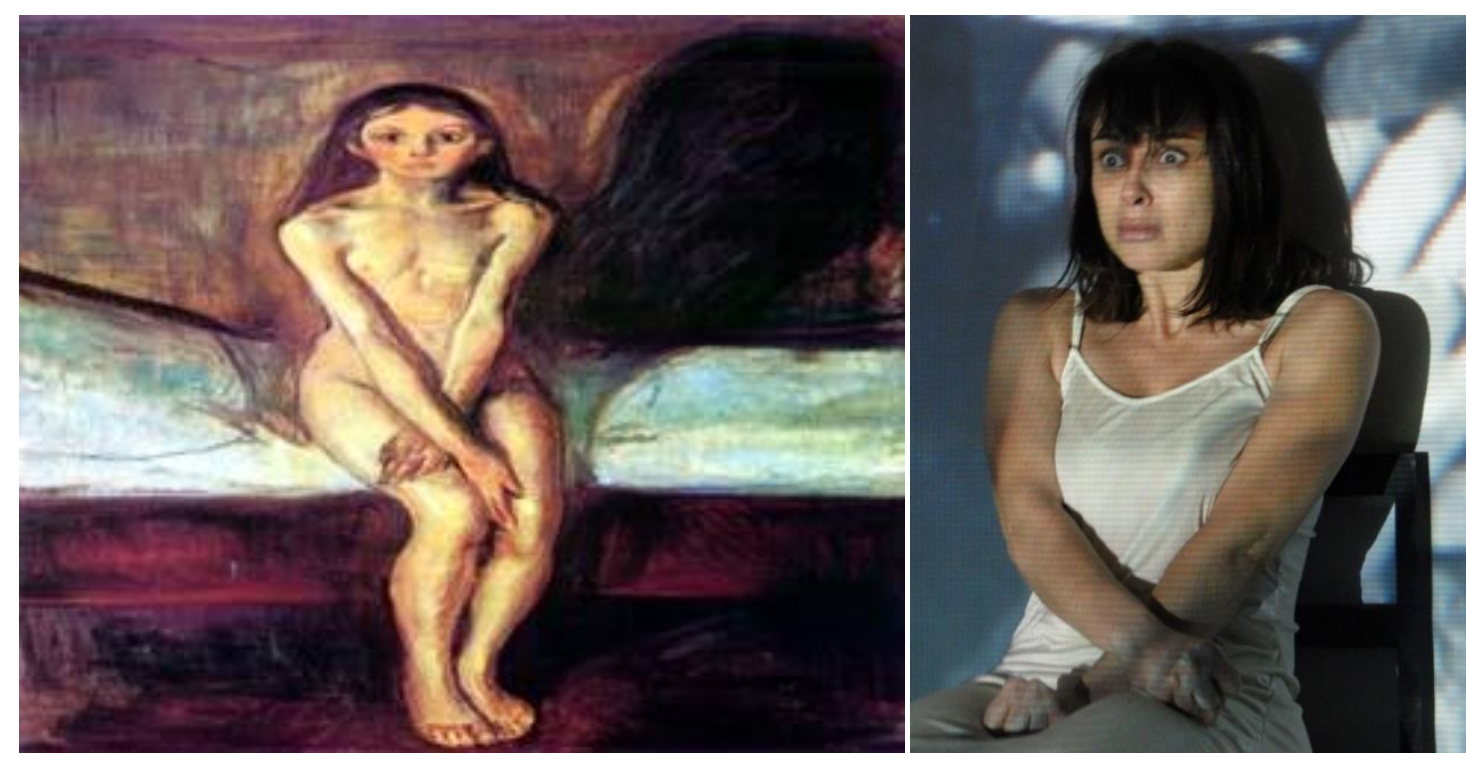

Figura 81: O Anteparo “A Menina do Munch” e a Impressão Digital

A regra de "incorporar" a figura: "reunir num só corpo, juntar, unir""15. Trata-se de dilata-la com a reverberação do anteparo interno. A plasticidade do olhar sobre o desenho é encenada. Se observarmos bem, “A Menina do Munch” está calma, enquanto a impressão digital (ao lado) tem o olhar assustado. Está no arranjo a imagem interna de 
sustentação que divide o foco: "Minha mãe morta diante de mim" ou "Eu matei minha mãe". Na interlocução com o CEPECA me dizem que a incorporação poderia ser mais lenta. Descrevo: "Olhos esbugalhados. Uma mão na coxa, a outra no joelho. Pés juntos, braços estirados, pulsos cruzados. A menina no Munch”. A sucessão dos anteparos verbais sustenta um percurso para o foco e estende o tempo da incorporação. Tal como na físicalização da "bola" de Spolin o olhar é guiado pela voz que percorre o corpo. Spolin utiliza "voz de instrução" contínua, durante o jogo, para ajudar o ator a “fiscalizar". Há um enlaçamento do ator na sua voz para que as impressões digitais sejam impregnadas de pulsão, energia: “Grite com os dedos do pé! Os olhos! As costas! O estômago! As pernas! Com o corpo todo!” (SPOLIN, 1992, p. 217). Ela narra o ator, o recorta com a voz, deslocando o foco do olhar pela superfície do corpo, enquanto este o tonifica. Há variações: fisicalizar um grito silencioso; a imobilidade provocada por um perigo; a imagem de uma bola ${ }^{16}$.

Aqui, há uma relação de oposição: a cadeia verbal freia (desacelera) enquanto a incidência da fala interna ("Eu matei minha mãe") acelera a incorporação da imagem. A incidência desta fala precisa de limites, de bordas - que, neste caso, são proporcionadas pelo desenho advindo da figura do Munch.

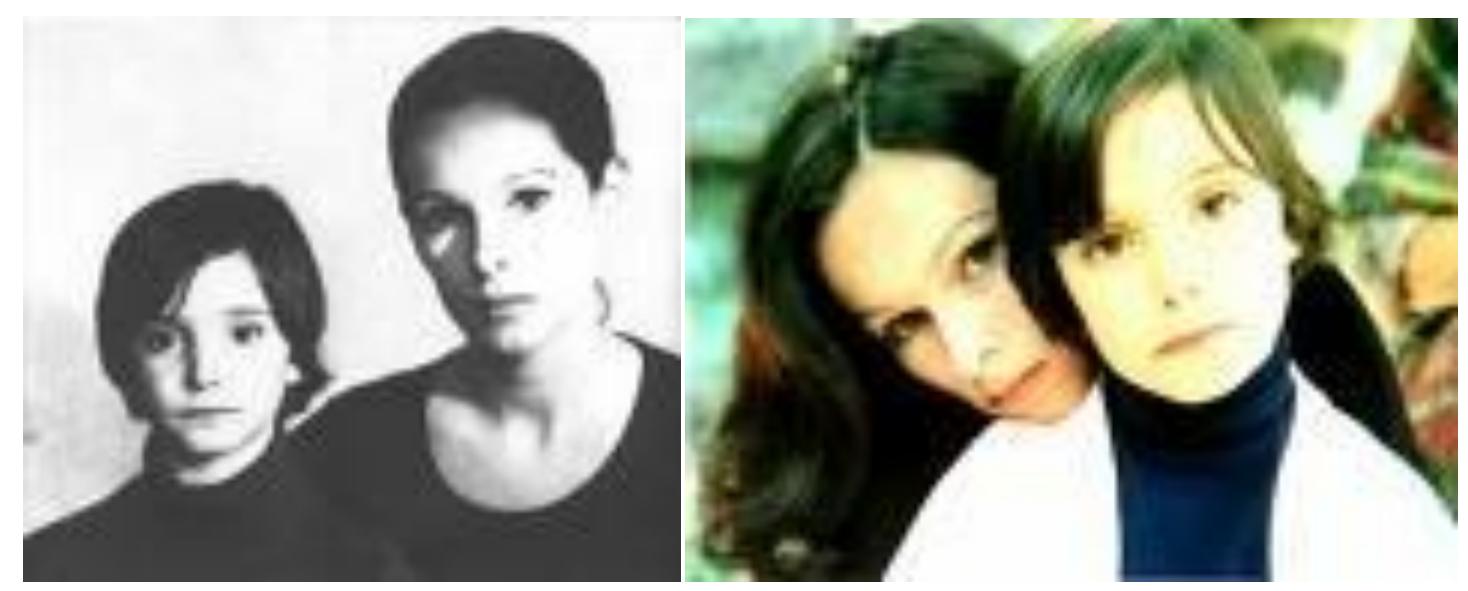

Figura 82: As atrizes Geraldine Chaplin e Ana Torrent em "Cria Cuervos" (Carlos Saura, 1976)

"Cria Cuervos no corpo": é a nomeação de um anteparo extraído do filme "Cria Cuervos" (Carlos Saura, 1976). Junto à figura da menina estão outros materiais: estranha; fria; cruel. A atriz dos Anos 40 Barbara Stanwyck também se torna um campo de extração de palavras: “elegante”, "dissimulada" - que fazem incidência.

16 O exercício de fisicalização da bola está descrito em SPOLIN, V.: Jogos Teatrais: O Fichário de Viola Spolin. São Paulo: Perspectiva, 2000, A41. 

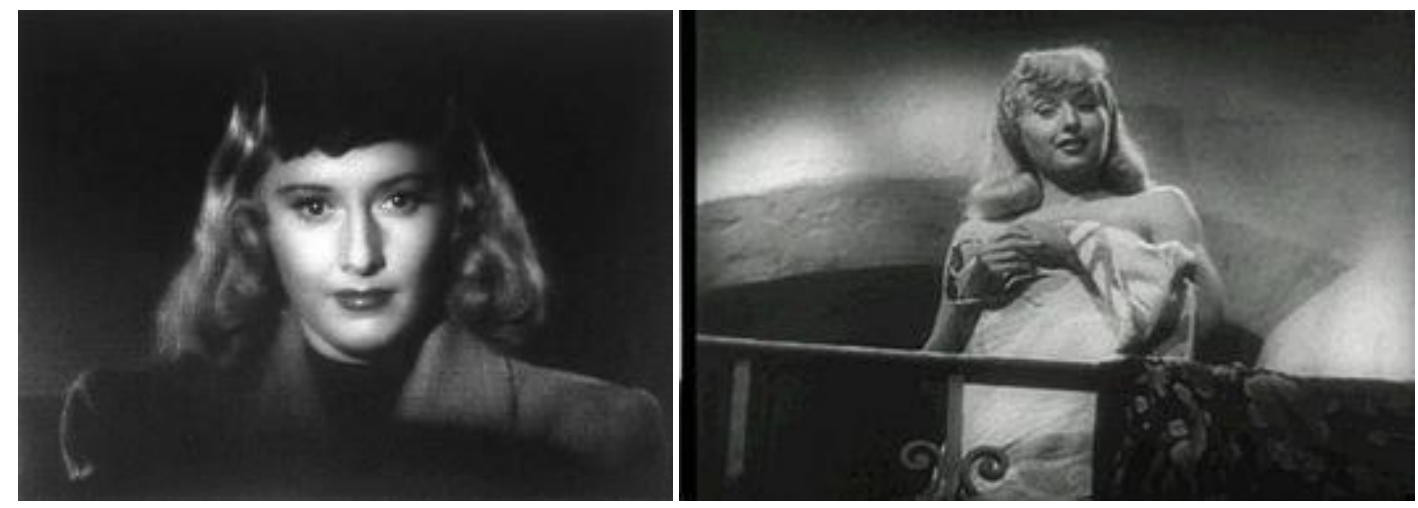

Figura 83: A atriz Barbara Stanwyck em "Pacto de Sangue” (Billy Wilder, 1944)

Por não estar descrito (apenas nomeado), "Cria Cuervos no corpo" se instala de súbito (diferente de “A Menina do Munch”, que se instala devagar). Também está, neste arranjo, a figura do ator Irandhyr Santos no filme "Febre do Rato" (Claudio Assis, 2012), recitando de maneira transloucada um poema. Esta figura entrou de forma acidental e se somou à "Cria Cuervos no corpo". Enquanto "Cria Cuervos" se instala de repente, provocando a troca do anteparo anterior (Munch), Irandhyr Santos lateja de maneira constante (enquanto eu caminho ao redor da cadeira).

Os significantes evocam (e ajudam a construir) uma visualidade da ficção: "Suzana observa, com fascínio, a morte da mãe”. No arranjo está a fala externa: "Saiu de casa com qualquer coisa de êxtase no olhar e voltou pálida!'”: som, plasticidade e enquadramento. A fala externa exige um tempo de enunciação e acaba por ajudar a enquadrar as reverberações dos outros materiais, que se desdobram no intervalo fixado na régua sonora. Posso introduzir um terceiro anteparo: "jornalista" - e assim instalar uma imagem vocal diferente (distanciada ou irônica). É da síntese entre todos estes elementos que a impressão digital vai surgir, com um mais além que perco de vista.

A fala externa "Saiu de casa com qualquer coisa de êxtase no olhar" é seguida por “e voltou pálida!”. Instalei um material entre as duas, para alterar a ação da segunda fala. Na fissura entre as palavras do texto do autor, coloquei: "A Menina do Munch". O apoio para "e voltou pálida" está neste material, que, antes mesmo da frase (que foi interrompida no meio) chegar ao fim, inscreve nova ação. Vê-se um jogo de instalação de ações para as falas no momento anterior a sua enunciação. A fala aparece como o segundo elemento da cadeia - e entra em relação com o corpo (e 
voz) construído (apoiado) por um material diferente. A fala entra em relação com esta ação construída por outro material.

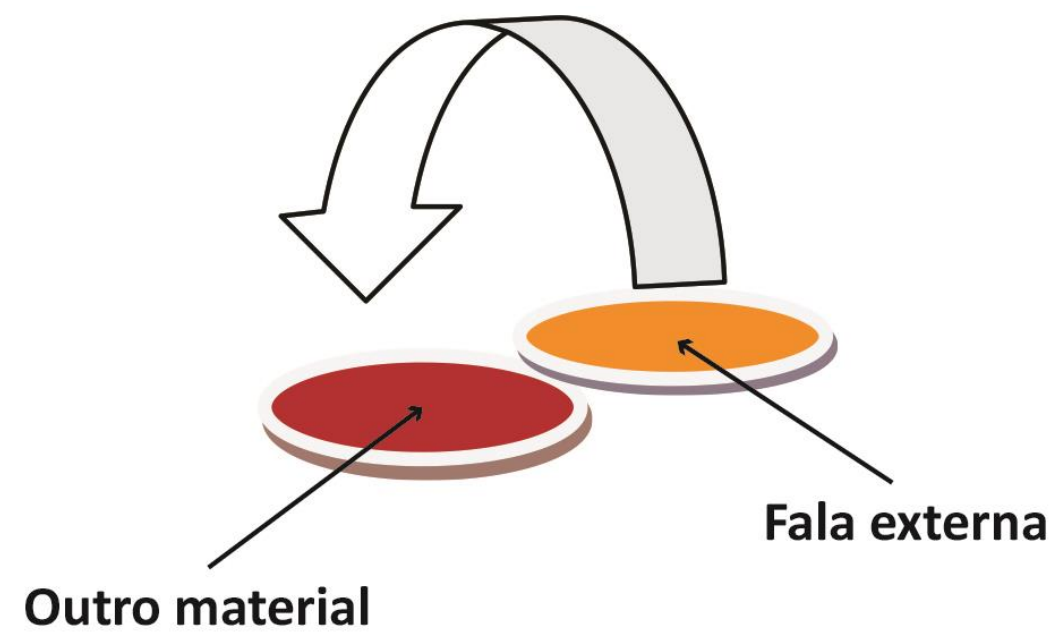

Figura 84: Fala Externa e Material que a Antecede

Historicamente, foi possível articular que uma fala é consequência de um movimento interno, intenção ou ação interna. No entanto, o ateliê testemunha que é preciso o material para que o efeito do movimento interno se inscreva. É preciso outro material para provocar o efeito da fala como consequência de um movimento interno. Graças à presença deste material, a ação aparece antes. E, então, a fala pode aparecer, para o público, como consequência desta ação ou de uma intenção que a antecedeu. É preciso a instalação de um material antes da fala para construir este efeito. "O pulso próximo ao rosto, o mindinho na boca, a mão delicadamente sobre o ouvido. Um Renoir. Toca levemente a perna abaixo do joelho. As duas mãos no cabelo. À esquerda mais para cima. O olhar baixo. A direita, quase na garganta”: a descrição de corpo extraída de figuras do Renoir e, logo depois, a fala externa "Visitar Marília" - inscrita como consequência (mas foi instalada, montada). 

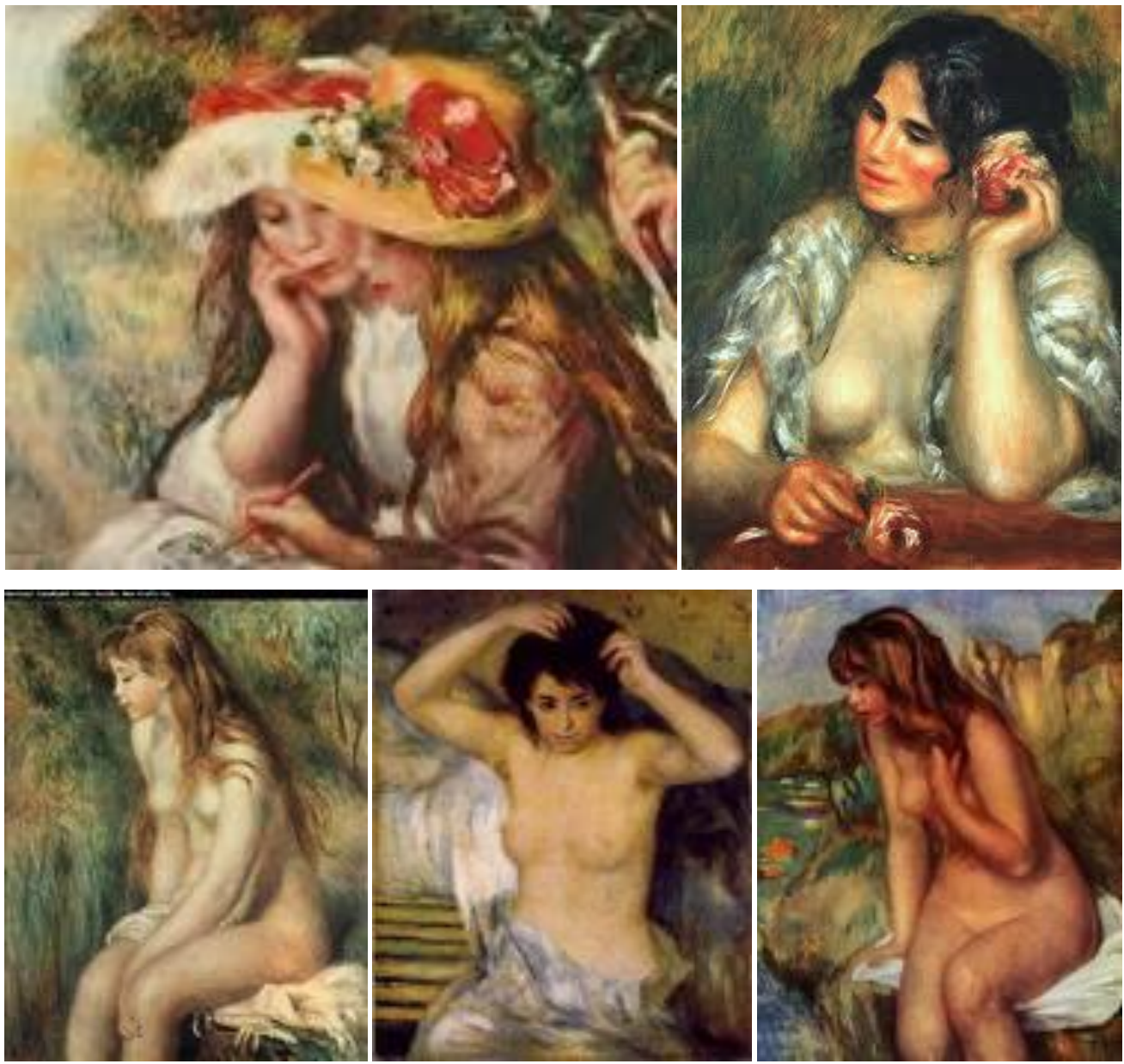

Figura 85: Figuras de Pierre-Auguste Renoir (1841-1919)

Quando a descrição vai para a régua sonora, sinto necessidade de criar mais material para a sustentação da ação interna (que levemente deforma o enquadramento plástico-corporal instalado com as figuras): "Não sabe o que falar. Ouvindo o seu homem. Ele é um amor, mas ela quer seduzi-lo. Como quem não quer nada. Eu tenho que segurar. É sede". A construção do pré-jogo, com sucessivas substituições entre duas cadeias:

Barbara Stanwyck / Não sabe o que falar. Ouvindo o seu homem / O pulso próximo ao queixo, o mindinho na boca, a mão delicadamente sobre o ouvido. Um Renoir / Ele é um amor, mas ela quer seduzi-lo / Toca levemente a perna abaixo do joelho / Como quem não quer nada / As duas mãos no cabelo / Eu tenho que segurar / A esquerda mais para cima. O olhar baixo / É sede / A esquerda na garganta.

A seguir, outros exemplos da composição entre enquadramento e incidência oculta. Estas falas internas vão para a régua sonora a título de "mostração"17.

${ }^{17}$ Brincadeira com “demonstrar" e "mostrar". 
$\checkmark$ A mulher está com o batom para fora dos lábios na fotografia de Steven Klein. A fala interna: "passando e borrando, passando e borrando". Em cena, o foco se divide entre ela e a atividade de passar (e borrar) o batom: enquadramento plástico corporal.

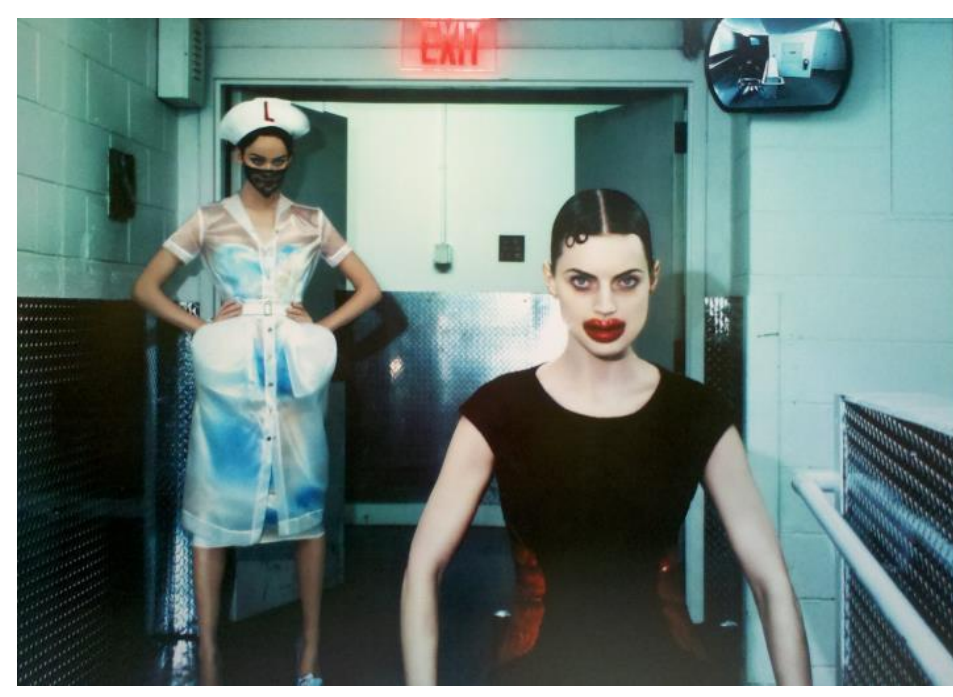

Figura 86:

Steven Klein, MUBE, 2011.

$\checkmark$ "Pai-homem-denso-saks": a figura do meu pai (denso e calado) e a paciente do Dr. Oliver Saks que não sustenta o corpo (não sustenta o tônus muscular, desaba no chão). "Saks" lembra "saco" e trás o peso entre as pernas (associado à masculinidade). Uma condensação de vários significantes. A paciente do Dr. Oliver Sacks desenvolveu uma técnica: ela fica olhando para cada parte do corpo, isoladamente, durante meses. Remonta o corpo; consegue sustentá-lo quando adquire uma posição teatral, artificialmente construída ${ }^{18}$. Há fala interna: "Menina sem tônus". Na ficção, o pai olha para o corpo da esposa moribunda. Há fala externa: "Entrou no quarto onde a mulher estava com o ácido corroendo o estômago". Há fala interna: "Ela vai morrer?" (depois de "Menina sem tônus"). Uma nova ação reverbera e sustenta aquele intervalo.

$\checkmark$ "Sacode, pequenininho; pequenininho, mas com masculinidade": associado na Memorização Através da Escrita - vem logo depois.

$\checkmark$ Em seguida vem: “Toca, gentilmente, os ombros". Graças a uma interlocução no CEPECA ("Você precisa fazer a plateia enxergar a mãe agonizante") eu "toco, gentilmente os ombros dela".

18 Expressões utilizadas pelo Dr. Oliver Sacks. Ver: SACKS, O. O homem que confundiu sua mulher com um chapéu. São Paulo: Cia das Letras, 1997. 
$\checkmark$ “Como faço para ser a mãe? Deito?”: a frase, do diálogo com Evinha Sampaio, entra no arranjo. Na régua sonora está: “Isso deita!” (como Evinha respondeu).

$\checkmark$ A voz pergunta: "E a culpa é de quem?" - instalando, no foco (no olhar), uma imagem inusitada de minha própria história de vida. Há fala externa: "Eu te odeio. Amo Jorge! Sempre amei Jorge! Por você só sinto nojo, nojo!"

$\checkmark$ “Dor! Bem na boca do estômago! Dor, dor, dor! Aiiiiiiiiii”: reverberação da experiência da dor, que "acorda" e é impressa.

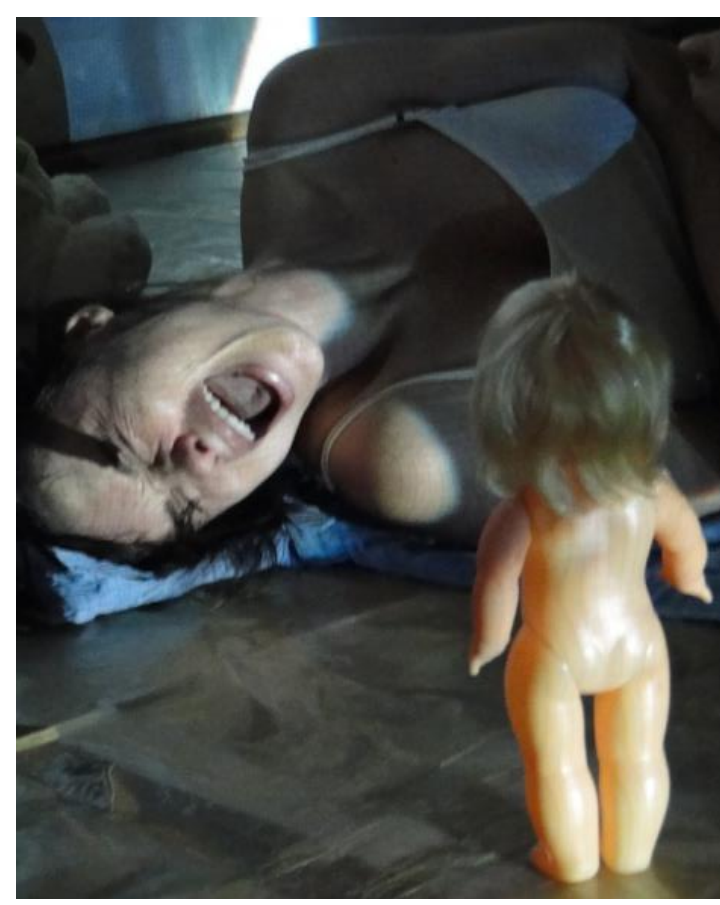

Figura 87: "Dor! Bem na boca do estômago! Dor, dor, dor! Aiiiiiiiiiii"

$\checkmark$ "Rejaniana": uma tentativa de abandono da construção corporal advinda da incorporação das figuras; e de instalação de um "corpo sujo" (a cotidianidade e suas imprecisões, o jeito de ser da Rejane, com seus vícios).

$\checkmark$ "O ouvir do Hugo, a boca do Fábio no meu ouvido": o foco é subitamente deslocado para o ouvido; o som que o invade; o que se escuta e visualiza. " $\mathrm{O}$ ouvir do Hugo": prática de Chékhov com Hugo Moss 19 . "A boca do Fabio no meu ouvido": extraído da vida pessoal da atriz. Na repetição da Memorização Através da Escrita corto "ouvir do Hugo" e fico com "a boca do Fabio no meu ouvido”. Instala-se o impulso para ouvir a avó chegando (na ficção).

19 Hugo Moss é da Inglaterra e Irlanda, mora no Brasil há mais de 25 anos e é brasileiro naturalizado. É diretor fundador da Michael Chekhov Brasil e um ator/professor treinado na técnica pela MICHA Michael Chekhov Association (EUA), da qual é membro e participante constante dos encontros internacionais nos EUA, Canadá e Europa (Fonte: http://www.michaelchekhov.com.br/quem.html Acesso em 30/12/2013). 
$\checkmark$ "Tira a meia-calça": é redução de "Vai tirando a meia calça enquanto fala". Uma instrução de jogo: tirar a meia calça para escrever na perna com o batom. Não escrevo mais, mas deixei a frase - no momento em que a avó chega para o velório. Parece uma ordem da avó (que a narradora lembra).

$\checkmark$ Duas falas internas juntas: "barulho de mar" e "música no corpo" - imagens diferentes a um só tempo (e se opondo). Começo a rir porque "barulho de mar" com "música no corpo" cria um sacolejo (como síntese). Vem uma associação: a menina rindo da mãe que "nem parecia esposa e sim a última das estranhas" (fala externa). O olhar da narradora aparece com o gosto de contar.

A noção do pensamento como lugar para onde se olha está em jogo desde que encontrei a instrução "olhar para os pensamentos" em um relato de Galizia sobre a criação de “A Vida e a Época de Joseph Stalin” (Robert Wilson, 1976). A instrução estabiliza o foco em certo lugar (ou em certa procura deste lugar). Ouço no CEPECA: "Você está mais tranquila". Galizia conta que Wilson colocava esta instrução para o ator "não representar". Olhar para o pensamento: uma tentativa de estabelecer um enquadramento que possa evocar a cotidianidade no corpo (fora da representação) sem o desenho que evoca a visualidade de uma situação de representação. Deparo-me com uma oposição: corpo cotidiano (leitura de "não estar representando") e teatralidade (atores "representam" e esta pode aparecer sem querer, "grudada" na área de vulnerabilidade).

Cada pré-jogo passa pela memorização e, antes do improviso, redução. Realizo cortes durante as repetições da escrita, depois de passar pela "psicografia": apelido criado (na prática pedagógica) para o momento em que a caligrafia borra; porque o ator deixa a incidência do fluxo do texto romper o enquadramento dos movimentos das mãos que escrevem. O pré-jogo é reduzido para uma cadeia curta e decisiva. Para entrar em cena, foco em apenas uma palavra. A cadeia verbal é um "monólogo interior" muito comprido para entrar em foco. A fala interna deve ser curta e incidente - demanda da relação com o outro (por exemplo, "Sai daqui!") - ecoando internamente. Usar uma demanda (do ator) é uma estratégia para articular a memória corporal ao enquadramento da fala externa ou plástica do corpo. Ela instala impulso e descarrega reverberações ${ }^{20}$. No ateliê, toma-se o termo "instalação" (Kusnet, 1992): de um jogo (consequentemente, da cena sustentada por este jogo).

${ }^{20}$ Vou situar melhor esta operação no quarto capítulo deste trabalho. 
Kusnet modaliza a instalação em "primeira" (o contexto do ator) e "segunda" (o contexto do personagem). Ele diz que a primeira instalação evoca a segunda (Kusnet, 1992). No ateliê, associações com a vida são usadas para criar laços entre a memória corporal e o enquadramento, que precisa estar cheio de incidência que o borre causando a dilatação. O enquadramento, constituído por um desenho (já impregnado) no corpo, faz incidência, mas precisa da incidência de outro material para borrá-lo. Muitas vezes, o ator se apropria do seu contexto, da sua situação de estar em cena; porque este contexto é a sua verdade (que faz incidência). Ele usa os seus pensamentos. Não os da situação ficcional, mas os do sujeito implicado na situação de jogo, em cena. O que se pensa em nome próprio pode ser ficcionalizado quando articulado à ficção. A fala que se captura em nome próprio (que diz respeito ao contexto do ator) é deslocada; situada no contexto da ficção: um efeito metonímico. $\mathrm{O}$ ator se articula ao contexto ficcional de maneira a fazer valer algo pessoal; enlaçar-se, mesmo que o enquadramento lhe seja estranho.

Em Kusnet, a operação do corte (e redução) é utilizada, também, para a imagem visual: "O ator reduzirá sua visualização a detalhes mínimos, aos mais condensados, mais excitantes" (KUSNET, 1982, p. 49). Não é possível visualizar uma imagem inteira, mas um corte - um vislumbre, associação. Neste corte, está implicado o recorte da linguagem. São significantes que o excitam. A imagem visual torna-se campo de extração também de anteparos verbais. A repetição da escrita permite fixar uma "tripa" de reduções. Os materiais produzidos por corte são enfileirados: temos uma subpartitura de falas internas condensadas, cada qual articulada a um arranjo. O préjogo (maior) sai do foco. Esta cadeia é, também, substituída: por uma fala apenas, que situa o foco no momento da largada. Uma fala curta e condensada, produzida por corte. Articula o que ficou de fora e ocupa o lugar de um "superobjetivo".

Stanislavski fala de uma "obtenção ativa do superobjetivo (...) que encerra em si todos os milhares de ações, unidades e objetivos, separados e fragmentários do papel” (STANISLAVSKI, 2005, p. 100). Ele pode ser construído com a plástica do olhar do personagem. No ateliê, o material de incidência (que o público não vê) não necessariamente precisa articular a ficção. Desde que situe o foco e prepare o ator, pode estar articulado ao contexto de bastidor. Graças aos encontros nos arranjos, acaba evocando uma visualidade da ficção (a "segunda instalação", na terminologia de Kusnet). 


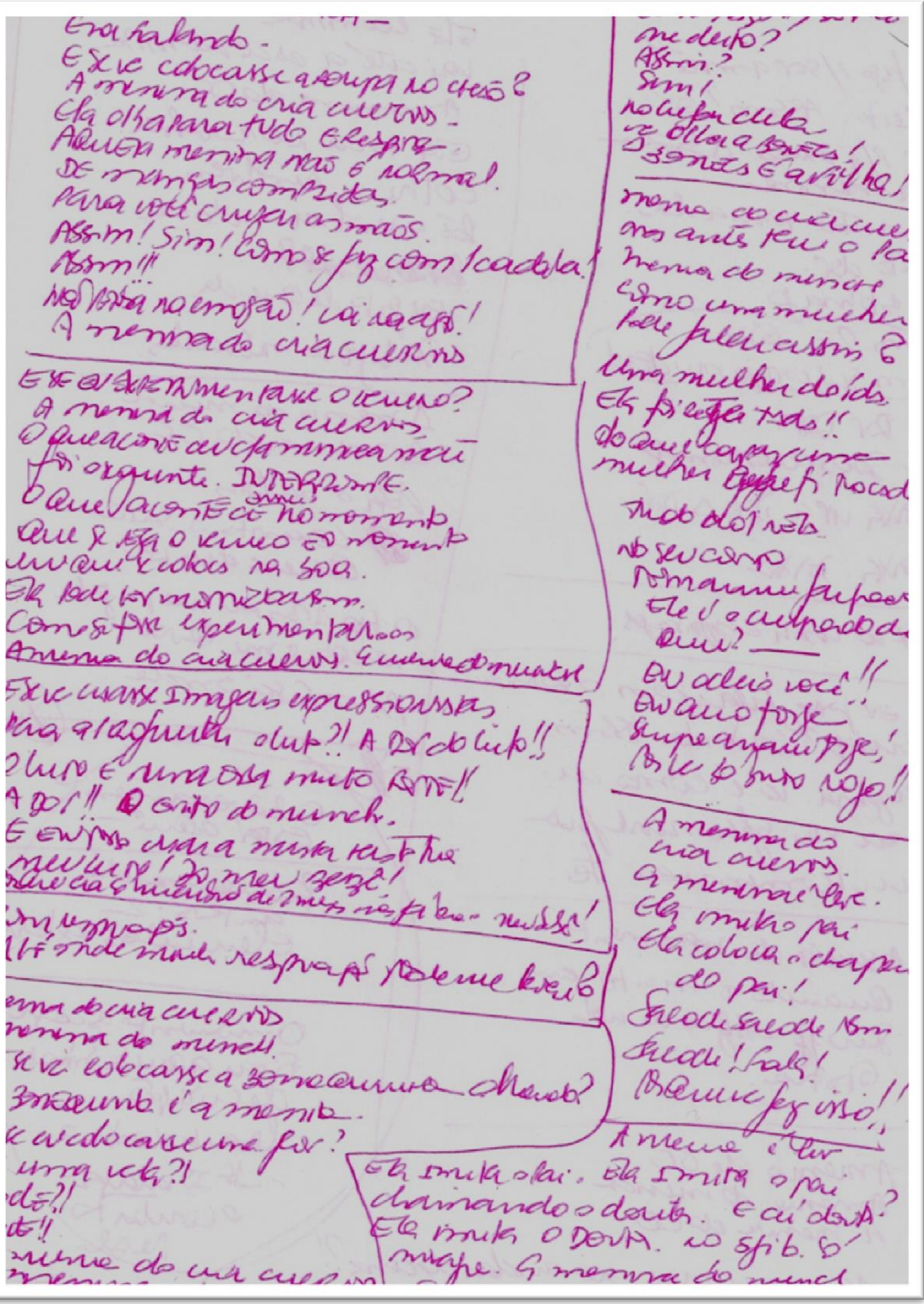

Figura 88: Pré-jogo da "Cena 1: A Morte dos Pais" 


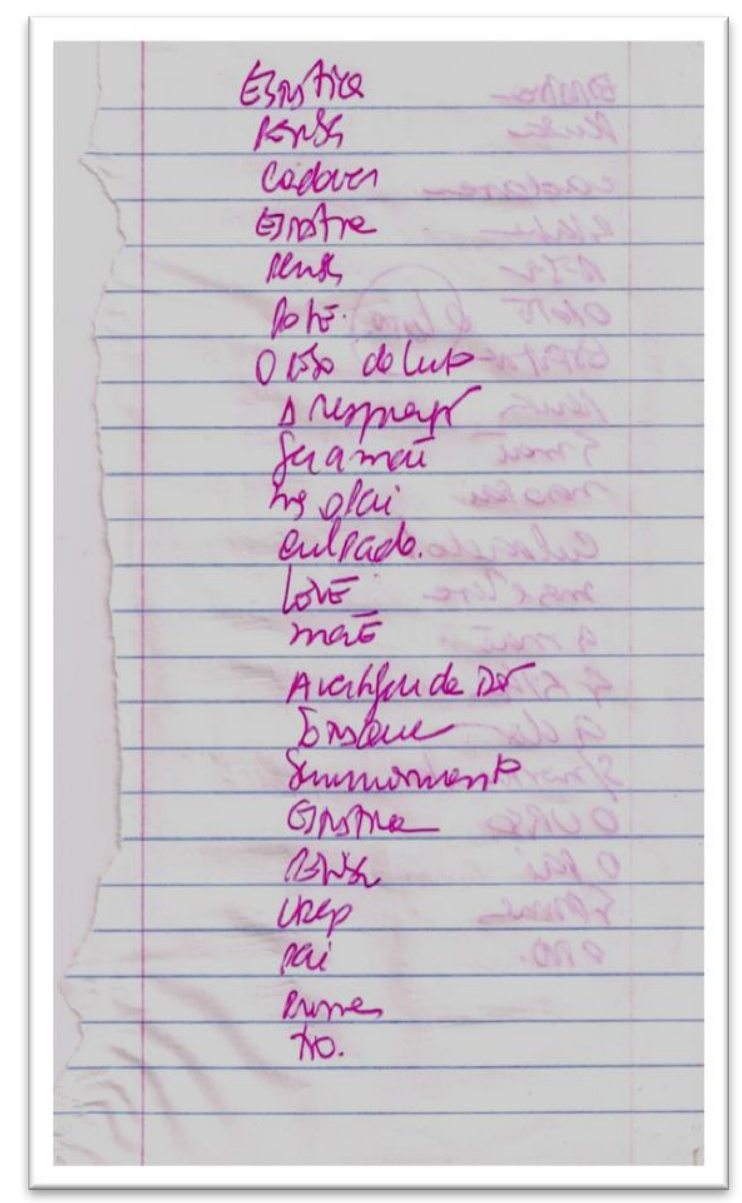

Figura 89: Redução do Pré-jogo da "Cena 1: A Morte dos Pais"

\subsubsection{A Reverberação de Um Treinamento: Ateliê na ESTC}

Por conta de um intercâmbio desenvolvido no CEPECA em 2013, ministrei uma oficina na "Escola Superior de Teatro e Cinema", em Portugal, chamada "A Plasticidade do Corpo Dramático"21. Utilizamos dois caminhos para incorporar as figuras. No primeiro caminho, os atores inventam nomes para as figuras que escolhem, incluindo-as no pré-jogo, em um lugar específico, junto a certa fala do texto dramático. No segundo caminho, as figuras são projetadas na parede. Os atores experimentam incorporá-las, impulsionados por associações e falas internas, música e a relação com o outro, descobrindo novas ações e desenhos corporais (mas estes não são fixados no préjogo).

${ }^{21} \mathrm{O}$ intercâmbio, realizado em março de 2013, foi coordenado pelo Prof. Dr. Eduardo Tessari Coutinho, vice-coordenador do CEPECA e contou com apoio da Pró-reitoria de Extensão da Universidade de São Paulo. A Revista PesquisAtor, editada pelos pesquisadores do CEPECA, lançou um número especial com textos sobre a experiência neste intercâmbio. 


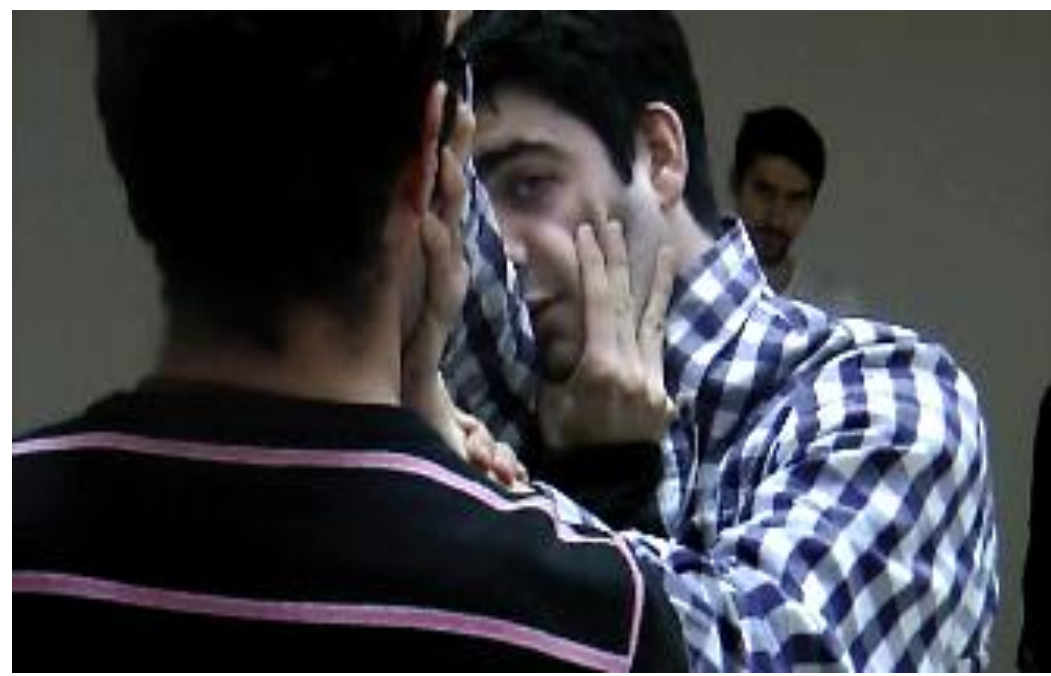

Figura 90:

Alunos da ESTC em Ateliê Cênico

No momento do improviso, em cena, com o texto, figuras memorizadas com o pré-jogo tenderam a reaparecer no lugar pré-fixado. Na medida em que se acomodavam, se transformavam, produzindo, mais ou menos, o estranhamento. Figuras incorporadas a partir da projeção também reapareceram, algumas vezes, no entanto sem lugares préfixados. Nos dois caminhos observamos instalação através da reverberação na tessitura corporal (por impulso) - proponho uma articulação com o que, na psicanálise, chama-se "atualização": vem pelo corpo. No entanto, foi evidenciado um momento de escolha entre "deixar-se atravessar" (pelo impulso da instalação da figura) - deixar-se ser moldado por ela - ou bloqueá-lo (evita-lo, desviar-se). No olhar, a associação.

Foi paradigmático o exemplo de uma atriz que não sabia o que fazer quando duas figuras apareceram ao mesmo tempo. Uma das figuras tinha sido colocada no préjogo e a outra não. Neste tempo vertical, ela teve de escolher. O ato de escolha gera imprevisibilidade: o impulso é aceito em um "átimo de segundo" (Clarice Lispector, 1968). É como se o impulso para a instalação de uma das figuras fosse uma contra ação da ação instalada pela outra. A escolha se dá como um ato, ruptura de um fio que prende o ator a uma delas. Este impulso fica registrado na partitura cênica. Há uma operação, que é a oposição entre os materiais (o ator é atravessado por este jogo), sendo que a incidência de um deles vence (e resulta como enquadramento plástico-corporal).

Evidencia-se, também, um jogo entre a visualidade de uma relação (entre os atores) e o desenho do corpo, que evoca ações inscritas nesta relação. É como se a relação "absorvesse",22, diluísse o desenho; esta plasticidade exacerbada, que construímos com figuras das artes plásticas que Silva chama "anteparos iconográficos"

22 Termos utilizando por Barba e também por Decroux, bastante disseminado na cultura teatral. 
(SILVA, 2010, pg.61). Na memorização, junto a falas internas e nomeações de figuras, nascem impulsos de ação em relação ao outro. Quando o outro entra em cena, é absorvido nesta relação. É como se os dois atores fossem sugados por uma relação que já estava presente na escrita e agora encontra carne. A visualidade da relação aparece quando o ator dá vazão aos impulsos que treinou durante a escrita.
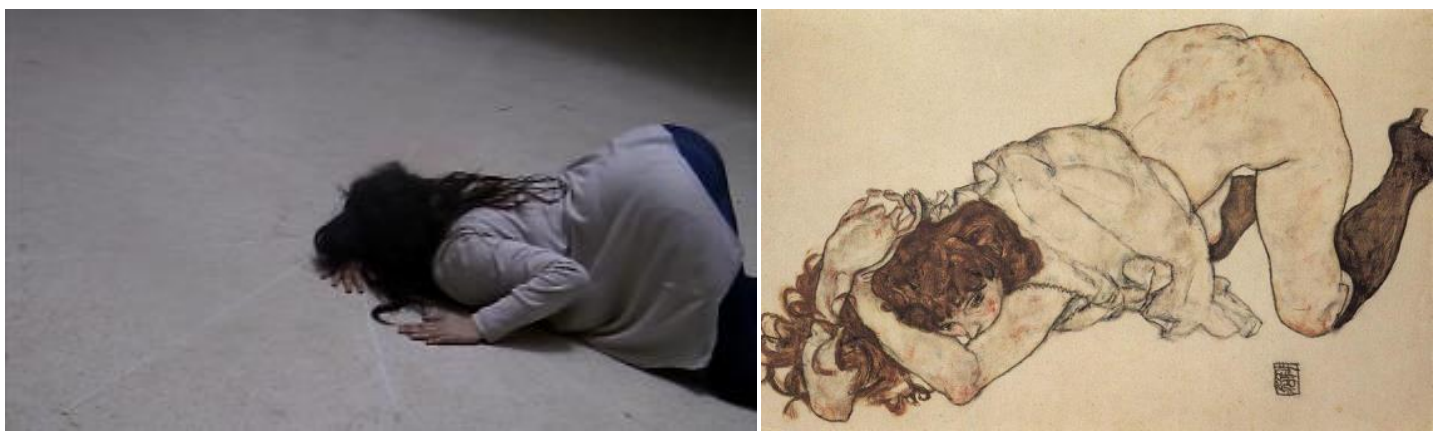

Figura 91: A figura nomeada no pré-jogo e a plasticidade corporal constituída em improvisação

Em cena, "apareceu" uma espécie de jogo entre a visualidade das ações inscritas na ficção e o intervalo, um espaço para certo estranhamento. Pude ver com mais evidência uma espécie de misto entre expressionismo e realismo: certos momentos de deformação e outros de diluição da forma na visualidade do cotidiano e da relação. $O$ desenho contorcido, abstrato, do corpo, estava sendo potencializado por uma prática de corpo exercitada, pelos atores, com o professor da ESTC Luca Aprea.
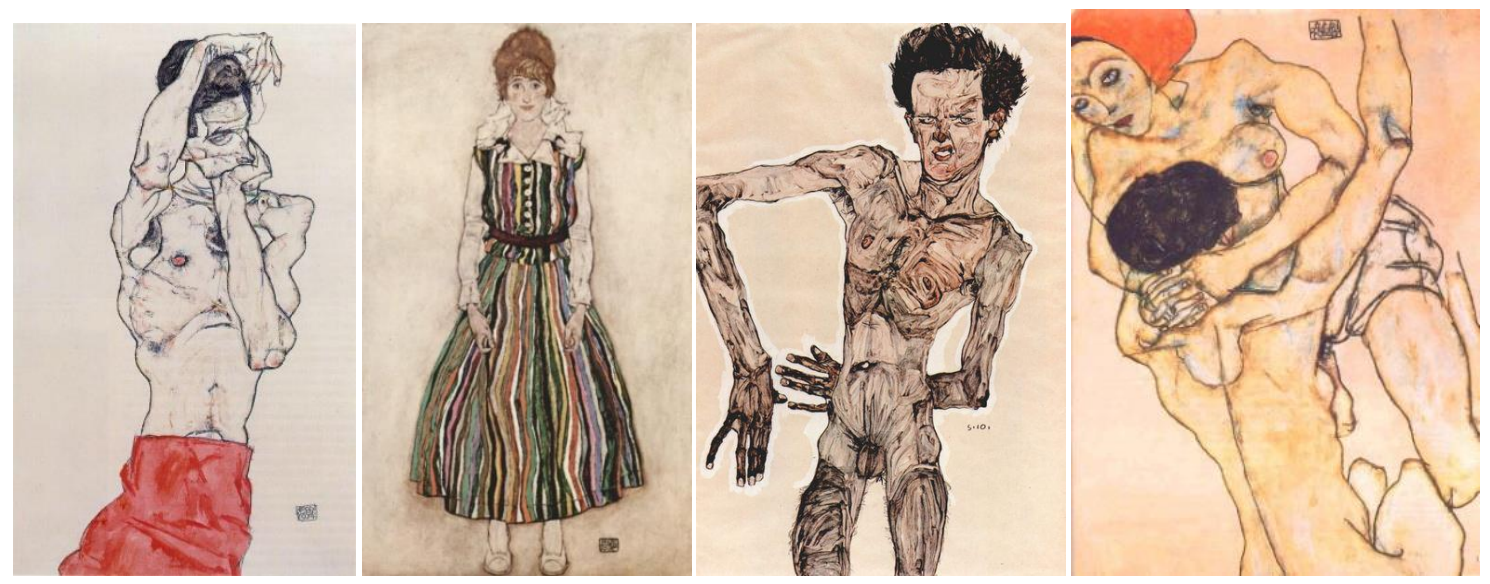

Figura 92: Figuras de Schiele utilizadas no Ateliê Cênico da ESTC 
Estava claro que o repertório constituído nas aulas de corpo estava sendo reencenado em uma área de vulnerabilidade corporal que atualiza ecos. Este repertório estava sendo ativado pelas figuras.

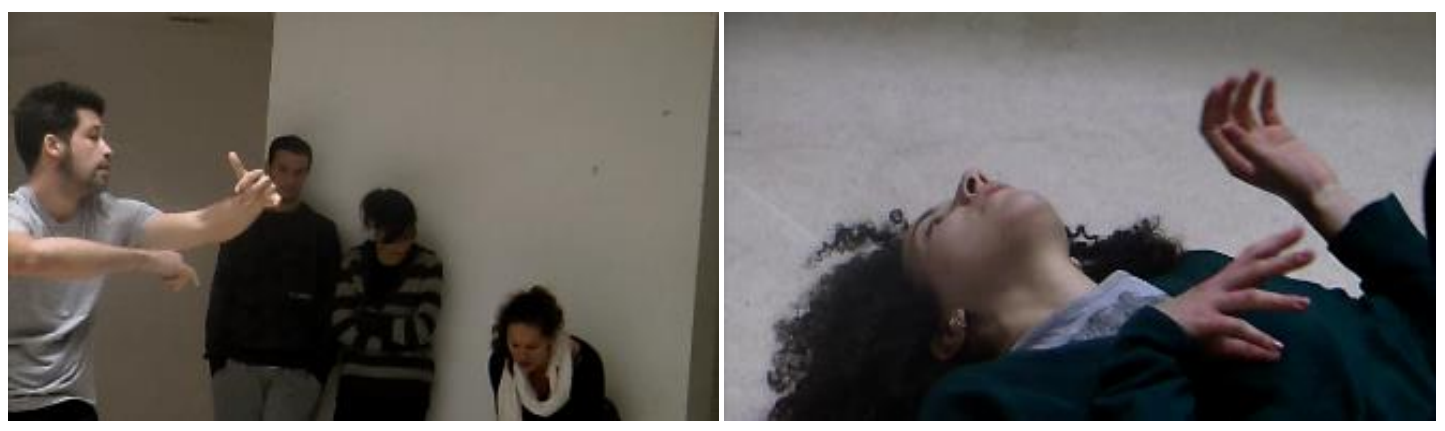

Figura 93: Alunos da ESTC em ateliê cênico

Professor de corpo na ESTC, Luca Aprea elaborou um procedimento para o treinamento corporal resultante de uma mistura entre pedagogias (como Barba, Decroux e Lecoq). Seu interesse está em deslocar o discurso (sobre o personagem) para o fluxo do movimento, deixando de lado a perspectiva da representação. Um ator deitado e o outro em pé. O segundo se apoia no primeiro e empurra uma parte do seu corpo para baixo. $\mathrm{O}$ ator deitado responde, tentando erguer-se. Os atores ficam um bom tempo assim, se empurrando. A repetição libera um fluxo, sujeito à incidência da música e dos significantes que surgem da relação com o outro. É visível a incidência, nos rostos, na respiração. Conforme a parte do corpo empurrada, se cria contorções. Nos improvisos com o pré-jogo, este repertório retornou e ajudou a enquadrar as impressões digitais entrando em jogo com os outros enquadramentos. Concluí esta oficina com a evidência desta terceira função: a vulnerabilidade (a atualização da escrita das palavras no papel e também na superfície do espaço-tempo cênico, cujas reverberações retornam).

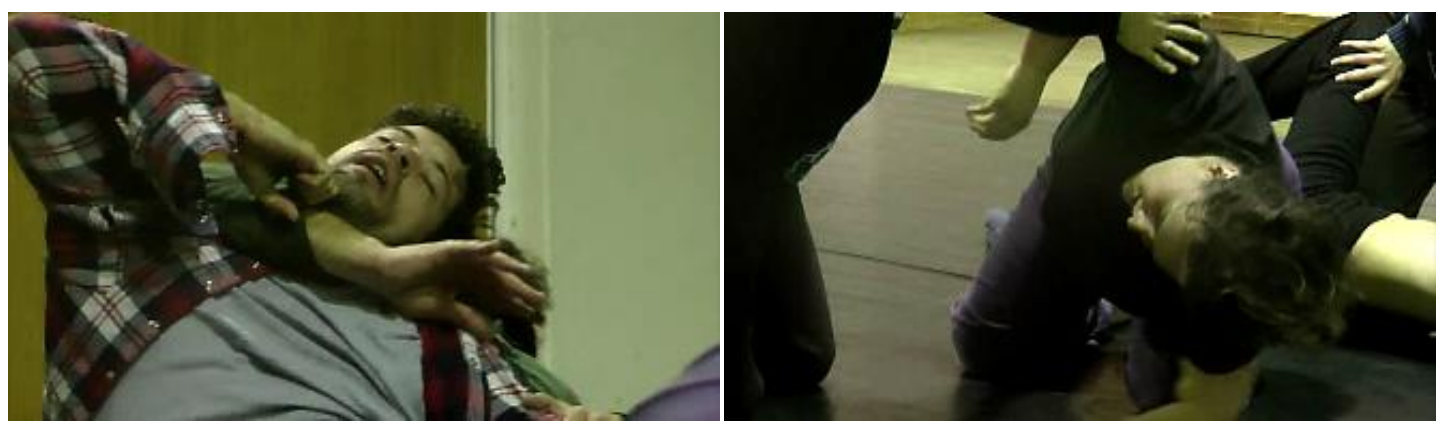

Figura 94: Alunos da ESTC na Aula do Professor Luca Aprea 


\section{VESTÍGIOS}

Será o encontro com o vazio que produz, pelo que o depoimento de alguns artistas nos informam, a absoluta necessidade de criar uma obra qualquer?

(Maria Rita Kehl)

\subsection{Stanislavski em Perspectiva}

\subsubsection{O Outro Texto}

Materiais atuando juntos; a área de vulnerabilidade onde a impressão digital se inscreve; o foco nos anteparos que se substituem e oferecem incidência instantânea; a atualização desta espécie de eco (de outras incidências) atravessando o corpo; jogo de enquadramentos e composição com diferentes plasticidades: o arranjo stanislavskiano torna-se um paradigma da estrutura. No entanto, admite-se a sua especificidade. Em um ateliê não é preciso utilizar, como enquadramento, a fala do texto dramático: pode-se lançar mão do texto que não é dramático; pode-se não utilizar a fala. Um ateliê pode não utilizar a diegese como enquadramento: pode lançar mão da plasticidade de um corpo que não evoca a imagem da ação, mas se configura como puro movimento, abstrato; pode trabalhar com um arranjo que não implique a plasticidade do cotidiano.

Quando Stanislavski se propõe a criar um corpo que evoca a plasticidade do cotidiano, a imagem da intimidade com aquele que poderia estar inscrito na plasticidade da realidade, escolhe um enquadramento específico. E quando se propõe a trabalhar com o texto dramático, insere, no arranjo, a plasticidade da diegese evocada a partir deste. No entanto, entra imediatamente em questão o processo de sua apropriação e a necessidade do ator construir outro texto, subjacente a este e que, com os seus efeitos de incidência, opera a apropriação de algo que se dá como enquadramento. O que nos interessa é a constatação da criação deste outro texto, atoral, que se torna paradigmática pela complexidade das cadeias acústicas.

Apesar da singularidade do arranjo stanislavskiano, interessa, a esta pesquisa, extrair uma estrutura onde o lugar de uma rede complexa de cadeias de palavras é assegurado na medida em que esta implica a sustentação de um corpo que deve estar pulsionalmente entrelaçado a certa modalidade de enquadramento. Testemunha-se um 
texto do processo; a produção de anteparos em uma espécie de pré-jogo (de preparação do jogo de criação cênico). O arranjo stanislavskiano evidencia o uso proposital de uma espécie de texto de anteparos. Palavras que despertam a excitabilidade, provocando a memória corporal e que o ator produz, propositadamente, enquanto disseca, divide, o texto dramático (analisa). Evidencia-se a área de vulnerabilidade, por onde a impressão digital é instalada, na medida em que o corpo, em jogo com o enquadramento espaçotemporal da cena, reverbera, também, o eco destas palavras. Uma espécie de atualização fora do foco.

A análise de texto configura-se como uma modalidade de pré-jogo, momento em que o ator deposita um desejo em um texto de próprio cunho, recheado de “estímulos criadores que forneçam impulsos de excitação” (STANISLAVSKI, 2010, p. 27). Os estímulos são extraídos da vida: "Lembranças vivas, pessoais, relacionadas aos cinco sentidos, armazenadas na memória afetiva do ator" (idem) - sujeitos ao encontro com aqueles que o texto fornece. Eles aparecem, em Stanislavski, modalizados em escuta (do som ou da imagem acústica), cheiro, toque, gosto e o olhar. Tal como Kusnet, Stanislavski enfatiza a função do olhar: trata-se de iluminar o texto como se ilumina um quarto escuro.

\begin{abstract}
Dos nossos cinco sentidos o da vista é o mais receptivo às impressões. $\mathrm{O}$ ouvido também é extremamente sensível. Por isso é que as impressões depressa se fazem, por intermédio dos nossos olhos e ouvidos. É sabido que alguns pintores têm o dom da visão interior, em tão algo grau, que podem pintar retratos de pessoas que eles já viram, mas não estão mais vivas. Alguns músicos têm igual capacidade de reconstruir, interiormente, os sons. Repetem mentalmente a execução de uma sinfonia inteira recém-ouvida. Os atores também possuem esse mesmo tipo de capacidade visual e auditiva. Utilizamnas para imprimir em si mesmos - e mais tarde evocar - toda sorte de imagens visuais e auditivas: o rosto de uma pessoa, a sua expressão, a linha do corpo, o andar, os maneirismos, movimentos, voz, entonações, traje. Mas ainda, certas pessoas, principalmente os artistas, são capazes de recordar e reproduzir não só coisas que viram e ouviram na vida real, como também, nas suas imaginações, coisas não vistas nem ouvidas. (...) Pontos luminosos crescem e se ampliam, fundindo-se uns com os outros, até preencherem finalmente todo o nosso papel. São como os raios do sol que, penetrando por uma estreita fresta da veneziana, projetam na escuridão apenas umas poucas manchas brilhantes. Mas quando se abrem as janelas, todo o aposento banhase em luz, banindo a escuridão (STANISLAVSKI, 1989, p. 188-189).
\end{abstract}

Trata-se de imagens que, sem estarem expostas na tessitura cênica, fazem incidência, graças à área da vulnerabilidade que implica seus ecos. Barba utiliza o termo "paisagem interna" e, também, "subpartitura". Junto (em arranjo) com o que está, em cena, exposto, há partitura subjacente (a subpartitura) visual. Mas, em Stanislavski, está, 
também, a subpartitura acústica detalhada: esta espécie de texto do processo que marca o corpo (sem que esteja exposto no enquadramento). A imagem visual interna é, muitas vezes, instável, escorregadia; transforma-se, multiplica-se. Já a imagem acústica pode se tornar material concreto se conseguirmos maneja-la, com a escrita, no sentido de fixar as suas cadeias. Isto implica a perspectiva de fixar um detalhamento de impulsos.

Stanislavski diz que a mente disseca o texto, desbravando-o: "auxiliar $e$ conselheira mais próxima das emoções. Que seja uma desbravadora, sondando a peça em todas as direções" (STANISLAVSKI, 2010, p. 28).

\begin{abstract}
Uma análise feita por meio do entusiasmo e do ardor artístico age como o melhor dos meios para trazer à tona os estímulos criadores de uma peça, e estes, por sua vez, provoca a criatividade do ator. À medida que o ator se entusiasma, vai entendendo o papel, e à medida que o vai entendendo, fica ainda mais entusiasmado. Uma coisa puxa e reforça a outra. (...) Que seja uma pioneira, abrindo novas picadas para as nossas principais forças criadoras (...). Quanto mais o ator tornar detalhada, variada e profunda esta análise pela mente, maiores serão suas possibilidades de encontrar estímulos para o seu entusiasmo, e matéria espiritual para a criatividade inconsciente. (...) No processo da análise, fazem-se pesquisas, por assim dizer, em toda a amplitude, extensão e profundidade da peça e de seus papéis, suas porções individuais, as camadas que a compõem, todos seus planos, a começar pelos mais evidentes e terminando nos níveis mais profundos, mais íntimos. Para isso, é preciso dissecar (..) É preciso sondar suas profundidades, camada por camada, descer à sua essência, desmembrá-la, examinar separadamente cada porção, rever todas as partes que antes não foram cuidadosamente estudadas, encontrar os estímulos ao fervor criativo, plantar, por assim dizer, a semente no coração do ator. (idem, p. 28-29)
\end{abstract}

Segundo ele, a análise detalhada permite entrar no reino do subconsciente: "Só com o auxilio da mente é que se pode penetrar no reino do subconsciente, que constitui nove décimos da vida de uma pessoa (...), sua parte mais valiosa” (STANISLAVSKI, 2005, p. 26). Ao revisarmos os termos propomos: o jogo da linguagem (de substituições e deslocamentos dos significantes) articula-se a uma espécie de gozo no corpo, “(...) definindo-se o gozo em si como tudo o que decorre da distribuição do prazer no corpo" (LACAN, 2008, p. 218). Não creio ser demais falar em gozo quando stankislavski postula: "excitação máxima" (um excesso).

Lá nas profundezas finais, no âmago da terra, onde se acham a lava fundida e o fogo, lá se desencadeiam paixões e instintos humanos invisíveis. Esse é o reino do superconsciente, o centro vitalizante e sacrossanto Eu do ator, o humano no artista, a fonte secreta da inspiração. Dessas coisas não temos consciência, porém as sentimos com todo o nosso ser (STANISLAVSKI, 2010, p. 30). 
Stanislavski teorizou com termos carregados de cientificidade: estímulo; mente e... inconsciente (ou, como vemos na tradução para o português, "superconsciente" ou "subconsciente"). Falta-me rastrear outras bibliografias para saber se estas variações são por conta da tradução ou de diferentes arsenais conceituais utilizados por Stanislavski. Se há alusão ao inconsciente freudiano, podemos dizer que, na medida em que o projeto de Freud era elevar a psicanálise ao estatuto de ciência, ele lançou mão da biologia e da neurologia, sem, no entanto, deixar de afirmar que, como um campo novo, precisaria de novos conceitos. Quando Lacan propôs o que chamou de "retorno a Freud", lançou mão de outros arsenais teóricos: a linguística (de onde extraiu o conceito de significante) e a antropologia estrutural, de onde buscou uma revisão da noção de inconsciente a partir das relações simbólicas implicadas na formalização da sociedade (postuladas por LeviStrauss), com suas leis de troca e suas cadeias articuladas. Utilizou a topologia, a teoria dos conjuntos, filosofia, travando diálogo com Heiddeger, Kant, Descartes, Aristóteles, Foucault, Hegel, Kojeve; questionando a teoria do sujeito como imanente, afastado do objeto do conhecimento; e postulando o inconsciente estruturado como linguagem e o sujeito implicado no desejo; enfatizando o que deste jogo escapa e se estabelece como resíduo, singularidade radical, que não se inscreve no saber. O inconsciente seria, assim, um saber que não se sabe: "O inconsciente, definido como um saber no nível do corpo substância (...)” (COLER, 2010, p. 15). "O inconsciente é o testemunho de um saber, no que em grande parte ele escapa ao ser falante" (LACAN, 1996, p. 190) "Mas o inconsciente é um saber, um saber-fazer com alíngua. E o que se sabe fazer com alíngua ultrapassa de muito o de que podemos dar conta a título de linguagem” (idem). Lacan lança mão do conceito de alíngua: o que do verbo (transmitido pela língua materna) escapa à linguagem.

\footnotetext{
Alíngua nos afeta primeiro por tudo que ela comporta como efeito que são afetos. Se se pode dizer que o inconsciente é estruturado como uma linguagem, é no que os efeitos de alíngua, que já estão lá como saber, vão bem além de tudo que o ser que fala é suscetível de enunciar. É nisto que o inconsciente, no que aqui eu o suporto com sua cifragem, só pode estruturarse com uma linguagem, uma linguagem sempre hipotética com relação ao que a sustenta, isto é, a alíngua (idem, p. 190)
}

A noção de inconsciente perde o seu fundamento biológico; o termo "mente" (tradicionalmente posto em oposição a corpo) é de pouca valia. No entanto, trata-se de não entrar deliberadamente no debate sobre a impressão digital implicar ou não algo de inconsciente. Poderia se dizer que sim, se sustentar o estatuto de arte. E se poderia dizer 
que o ator está implicado, de alguma maneira, no inconsciente. O artista aparece como o que toca o Real (Real enquanto indizível); a sua criação circunda um resíduo da Outra Cena (inconsciente freudiano). De maneira que, na arte, apareceria um saber que não se sabe; uma espécie de figuração do saber inconsciente. No entanto, esta é uma hipótese que precisaria ser desenvolvida. Não é o caso, neste trabalho, de entrar neste debate, pois ele exigiria uma série de outras articulações (que me levariam para fora do objeto que recorto). Deixo registradas estas notas e sigo com a noção de "fora de foco", realmente operacional no ateliê.

Acredito que, o que Stanislavski está debatendo, é a atualização, na memória corporal, de ressonâncias das incidências fora do foco; algo que ocorre à revelia do ator e que só se percebe a posteriori (porque a impressão digital precisa ter sido inscrita para ser percebida). O seu testemunho reafirma a existência da área de uma vulnerabilidade implicada na tessitura corporal. Quando vejo, aconteceu: o corpo foi sozinho e a leitura deste processo funciona como um anteparo que situa o foco dividido. Já está lá outra produção antes que se possa deter o olhar. É possível, apenas, entrever, de relance, com o canto do olho, a sucessão de impressões que implica o descarregamento de diferentes incidências. Com a leitura da impressão digital se produz novo anteparo: significante que entra no jogo, participando do arranjo e transformando a impressão digital inscrita na tessitura da cena. "Leitura" aqui tomada em referência a uma escuta de significantes e ao ato de interpretação que implica o desejo do sujeito.

Reconhecendo-se que há algo de não intencional na impressão digital, tomase a "intenção da personagem" (categoria de Stanislavski) como uma modalidade de anteparo que não exclui, no entanto, a não intencionalidade (por esta ser estrutural). A evidência deste material (a intenção, quando a resultante implica o não intencional) testemunha o lugar dos anteparos acústicos, que pode ser preenchido, também, com outras modalidades. Não, exatamente, a intenção da personagem (já que esta é uma modalidade stanislavskiana), mas uma regra de jogo (Spolin), por exemplo. Propõe-se o lugar dos anteparos acústicos como estrutural. Encontra-se o lugar da escuta de significantes como estrutural: significantes que se revezam pelas cadeias por onde o desejo se desloca. Movimentar estas cadeias é fazer deslocar o desejo. A teia das associações suporta o imaginário (o sentido). Às vezes implica mesmo um excesso de sentido. Mas quanto mais o sentido se estabelecem mais ele escapa. Plástico, o sentido se transforma. O jogo é infindável. O jogo da linguagem transforma a imagem e implica a intensidade do afeto. $\mathrm{O}$ ator brinca com a pulsão de ver (e rever). 

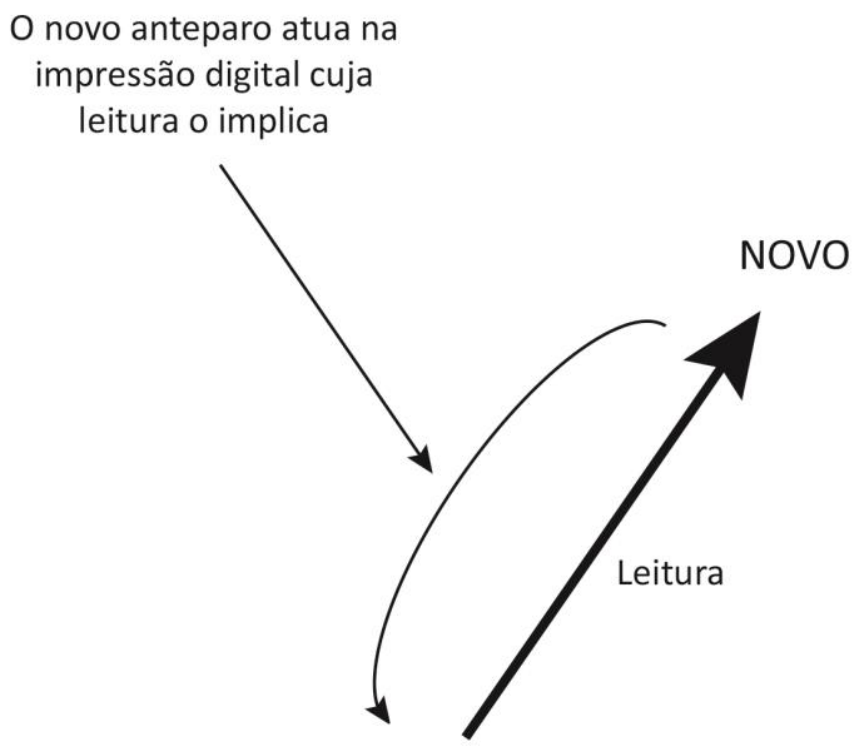

ANTEPARO DE

ENQUADRAMENTO

IMPRESSÃO DIGITAL

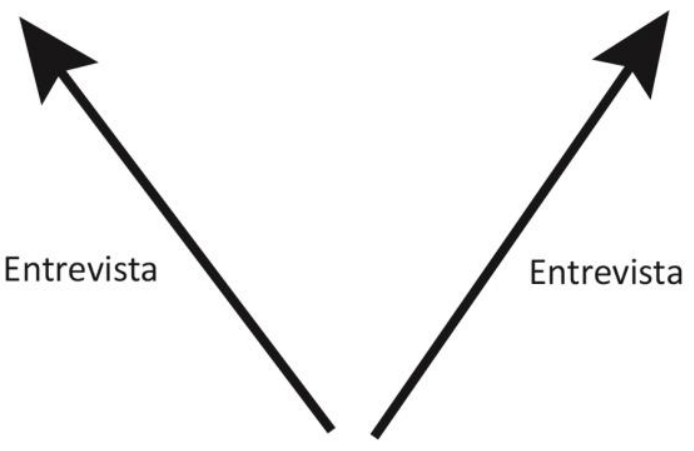

DIVISÃO DE FOCO

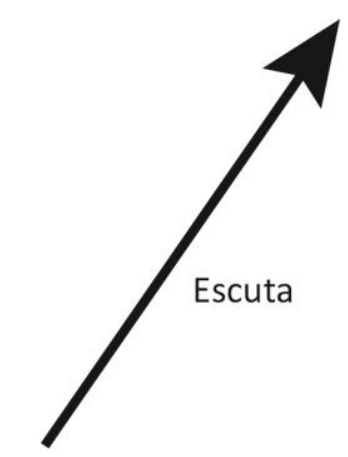

ANTEPARO ACÚSTICO

SITUA O FOCO

Figura 95: A Escuta das Impressões Digitais

Obs. O termo "entrevista" está sendo utilizado com o sentido de "ver de relance" 
Stanislavski testemunha uma articulação entre o significante e algo que se situa como excesso. As cadeias se proliferam com mais e mais associações. A excitação, que se encontra no fundo desta construção, ele chama "paixão" ou "instinto", remetendo-o, novamente, ao "reino do superconsciente". Apesar do termo trieb (Freud) ter sido traduzido como instinto, no alemão é "pulsão" (que implica inscrição do sujeito na linguagem quando dela escapa algo do pulsional que não se pode ser significantizado) ${ }^{1}$. Assim, o que posso entender é que os anteparos, tal como os significantes, giram em torno de um núcleo irredutível, que aparece como "causa" (como que pinçando a pulsão corporal na medida em que é linguagem que excita).

\begin{abstract}
O ator abre poços, fura túneis, e, depois de cuidadosa investigação, conclui que a montanha encerra uma riqueza incalculável. Mas a busca das delicadas e diminutas criações da natureza tem de ser feita em locais inesperados. (...) Quanto mais fundo forem-se adentrando os homens, maior será o assombro deles perante a sua extensão. (...) Súbito alguém exclama: "Ouro! Ouro!" Passa-se o tempo e as picaretas param. Os operários, decepcionados, deslocam-se para outro ponto. O veio sumiu, foram infrutíferos os esforços; fenece-lhes a energia; (...) sentem-se perdidos, não sabem para onde se voltarão. Dentro em pouco ouve-se outro grito e todos eles recomeçam, com entusiasmo, até que a empreitada, mais uma vez, se revela decepcionante. Isto se repete vezes sem conta até que, finalmente, eles deveras acham o filão rico. (STANISLAVSKI, 1989, p. 282)
\end{abstract}

A montanha de canais que Stanislavski percorre no texto - "Um papel é como uma montanha imensa" (STANISLAVSKI, 1989, p. 281) - é análoga às cadeias das imagens acústicas e visuais que se encontram estruturalmente em um processo de criação: um material novo pode incitar, causando a pulsão da encenação, e perder a incidência, enquanto outro passa a incitar. Há um revezamento do que aparece e abandona o ator. Os significantes se substituem. O artista utiliza a livre-associação (além da associação de ideias). A livre-associação implica cadeias na vertical que não estão enquadradas na plasticidade do que se compreende. A livre-associação implica um não enquadramento do material em uma relação de sentido. No entanto, quando se escolhe um objeto pela pulsão de encenar a sua incidência, nesta pulsão está implicado o sentido de um diálogo com a cultura, com a perspectiva de construir uma poética da cena (que foge ao sentido e implica enigma com a visualidade e sonoridade). Utilizar o enquadramento da plasticidade de uma ação pode ser uma escolha; e esta ação ficcional pode ser constituída como visualidade e não como sentido.

\footnotetext{
1 "Significantizado" em referência a significante, ao invés de significado. Trata-se do que não tem inscrição na linguagem, no significante.
} 
De qualquer forma, a incidência de um anteparo pode passar: o ator esquece; o corpo adormece; o enquadramento seca. Sem o eco da incidência na memória corporal, a impressão não pode ser atualizada nesta área de vulnerabilidade, fora do foco, no lugar da não intencionalidade. Por isto, a necessidade de escrevê-la; de registra-lo: "O ator deve memorizar e escrever os fatos, sua ordem de sequencia e a relação física, exterior, entre eles" (STANISLAVSKI, 2010, p. 31); "Pedir que escolham um quadro com poucas figuras e o descrevam em um texto" (KNÉBEL, 2002, p. 41); "Ele disse que através de tudo o que tivéssemos escrito em nosso caderno, seriamos capazes de reconstruir, memorizar e repetir a improvisação que havíamos acabado de fazer" (RICHARDS, 2012, p. 13).

\begin{abstract}
Sinto que fizemos um pálido esboço dos impulsos para a vida física nas circunstâncias da vida e nas condições propostas pelo papel. Agora devemos registrá-las por escrito. Começou a evocar todos os impulsos para agir que observara em si mesmo e eu os anotei. (STANISLAVSKI, 2005, p. 269-270)
\end{abstract}

O significante também aparece, em Lacan, como lugar. Ele dá o exemplo dos livros na biblioteca: tiramos um livro da estante, mas seu lugar permanece ${ }^{2}$. Analisando o conto "A Carta Roubada" de Edgar Alan Poe, Lacan formaliza o significante como letra: “A letter, a litter, uma carta, uma letra, um lixo” (LACAN, 1998, p. 28).

\footnotetext{
(...) o que está escondido nunca é outra coisa senão aquilo que falta em seu lugar, como é expresso na ficha de arquivo de um volume quando ele está perdido na biblioteca. E este, de fato, estando na prateleira ou na estante ao lado estaria escondido, por mais visível que parecesse. É que só se pode dizer que algo falta em seu lugar, à letra, daquilo que pode mudar de lugar, isto é, do simbólico (idem).
}

Forma-se uma cadeia subjacente, cheia de lugares vazios que vincam; deixam marquinhas. Por onde passa a vida corporal. O instrumento para vincar são palavras escritas. Quando se escreve, se vinca o fluxo de uma sucessão de trocas. O eco, na memória corporal, se apaga. A incidência cessa e o enquadramento seca. Com a palavra escrita, se tem para onde voltar. O significante está lá. Passa o tempo. Mas retomamos. Então, se cria outra palavra para pôr naquele lugar (ou se repete a escrita do mesmo encadeamento, evocando nova imagem e outros ecos na tessitura corporal), para reacender a incidência. Em cena, são despejados: espécie de fluxo (substância interior, segundo Stanislavski). Sobre a escrita, diz Stanislavski:

\footnotetext{
${ }^{2}$ Ver: LACAN, Jacques. Escritos. Rio de Janeiro, Jorge Zahar Ed., 1998.
} 
A medida que vai aumentando a experiência em relação à peça e ao seu conteúdo, este método ${ }^{3}$ ajuda não só na seleção dos fatos e em nossa orientação quanto a eles, mas também para chegarmos àquela substância interior, às suas inter-relações e interdependências (STANISLAVSKI, 2010, p. 31).

Em Stanislavski, rompe-se a cadeia contínua do texto do autor e se cria os fragmentos do texto do ator. Aquele pedaço da fala do texto-dado (um enquadramento específico) está alicerçado por um anteparo (uma marca de incidência) subjacente ao enquadramento. Enquanto a palavra da própria lavra causa incidência, a palavra do autor enquadra.

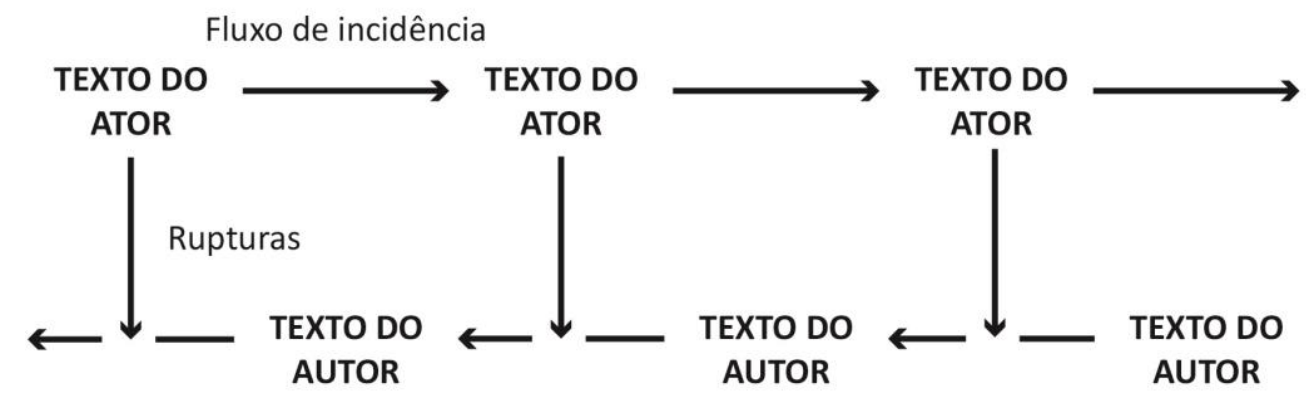

Fluxo de enquadramento

Figura 96: Fluxos de Incidência e Enquadramento

$\mathrm{O}$ fato de ter rompido a malha sonora do autor, talhou vincos. Estes, que serão preenchidos pelas impressões digitais, criadas nas fissuras abertas. Trata-se, no ateliê, de criar vincos, mesmo sem o enquadramento da fala dramática. Mesmo ao tratar-se de outras plasticidades. De qualquer maneira, temos uma articulação entre a linguagem (cadeias de anteparos), o imaginário (o sentido, que se transforma; a relação do eu com o mundo, o universo ficcional) e o gozo (no que ele implica de Real, isto é, de não inscrito na linguagem, figurado pelo excesso de afeto depositado no corpo). A produção textual de próprio punho: um texto de anteparos; um texto dos bastidores ${ }^{4}$. Ele implica estes talhos, por onde a vida flui; transbordando, excedendo o enquadramento. O préjogo é estrutural. Mesmo que o ator não detalhe uma sequencia de anteparos, mesmo

3 O autor está se referindo ao ato de "anotar".

4 Seria interessante fotografar os cadernos de atores stanislavskianos. Sabemos da existência dos cadernos de Kusnet através de Ney Piacentini, autor da dissertação, defendida na da USP, "Eugênio Kusnet, do Ator ao Pedagogo". Em entrevista, Renato Borghi fez referência ao caderno de Kusnet como "outra peça”, subjacente a de Gorky. A existência dos cadernos deixa entrever este "outro texto", de próprio punho (Ney Piacentini, testemunho oral em 19/03/2012). Em prefácio do livro de Kusnet ("Ator e Método"), Fernando Peixoto pontua o caráter paradoxal de suas performances, que aliam passionalidade e método. 
que não utilize a escrita para vincar o seu eco e retornar a ele, tem a memória das vozes de bastidor. Mesmo que não estejam sistematicamente organizadas (como no caso de Stanislavski), existe o seu lugar na estrutura. Consideramos os estilhaços de som e um deixar-se levar pelo verbo (que causa afeto e, enlaçado a uma imagem de si, incita ao excesso). A relação com o processo, o diretor, o elenco, o público, a cultura, a poética cênica e o seu próprio pensamento está, estruturalmente, articulada à produção de afeto no corpo.

No caso de Stanislavski, trata-se de um arranjo bastante complexo, que conta com a plasticidade de uma situação, dos sons, das relações; implicando a constante leitura com a produção de novos anteparos; onde a função do foco aparece, bem como a perspectiva da sua invasão por anteparos e o que é despejado na área de vulnerabilidade.

Certa noite, numa festa em casa de amigos, fazíamos várias brincadeiras e, por pilhéria, resolveram operar-me. Trouxeram mesas, uma para a operação e outra com supostos instrumentos cirúrgicos. Penduraram lençóis, trouxeram ataduras, bacias, muitas vasilhas. Os cirurgiões envergaram aventais brancos e eu fui metido numa camisola de hospital. Estenderam-me na mesa operatória e vendaram-me os olhos. O que me perturbava era a atitude extremamente solícita dos médicos. Tratavam-me como se eu estivesse desenganado e tudo o que faziam era com a maior gravidade. Súbito, a idéia me riscou pelo cérebro: "e se eles me abrirem mesmo?" A incerteza e a demora afligem-me. O meu senso auditivo aguçou-se e tentei não perder sequer o menor ruído. Ouvia-os, por toda parte, cochichando, despejando água, fazendo tilintar os instrumentos. Volta e meia uma grande bacia retumbava, lembrando o dobre de algum sino fúnebre. "Comecemos", sussurrou alguém. Alguém segurou com firmeza o meu pulso esquerdo. Senti uma dor surda e depois três fortes espetadelas... tive de estremecer. Esfregaram no meu pulso uma coisa áspera, que ardia e, depois o envolveram em ataduras. Eu ouvia o rumor de pessoas que entregavam objetos ao cirurgião. Afinal, após uma pausa, puseram-se a falar algo, riram, cumprimentaram-se. Desvendaram-me os olhos e vi, aconchegado em meu braço esquerdo... um recém-nascido. Nas costas da minha mão eles tinham pintado uma cara tola, infantil (STANISLAVSKI, 1989, p. 297-298).

O exemplo é paradigmático por testemunhar a incidência de um pensamento que "risca o cérebro" e "martela dentro da cabeça", enquanto as resultantes digitais vão aparecendo no jogo com um enquadramento.

O primeiro passo necessário é o relaxamento da tensão muscular. Em seguida vem: escolha um objeto - aquele quadro? - O que representa? Qual o seu tamanho? As cores? Tome um objeto distante! Agora um círculo pequeno, não mais distante que os seus próprios pés! Escolha algum objetivo físico! Motive-o, acrescente primeiro uma e depois outras ficções imaginativas! (...) Faça várias suposições e sugira circunstâncias possíveis, para colocar-se nelas (idem, p. 280) 
Trata-se de criar um arranjo para que materiais possam se revezar no foco. $\mathrm{O}$ arranjo é complexo e implica tanto os materiais inscritos na ficção quanto os materiais inscritos no contexto da criação da obra; os que marcaram seu lugar nos ecos corporais e os que estão dispostos na tessitura cênica no momento da incidência. É importante pontuar que o arranjo implica materiais do contexto da criação da poética corporal, apesar da plasticidade da ficção ser utilizada. A presença do outro (os detalhes que oferece à leitura); a relação (que também se constrói); as associações repentinas; as falas improvisadas (que o ator cria para substituir as do autor no início); circunstâncias dadas inventadas ou extraídas do texto; a contradição ${ }^{5}$; detalhes imaginativos (renovados a cada apresentação) - considera-se a incidência do arranjo enquanto um dos materiais pode situar o foco. O superobjetivo, por exemplo: "atrai nossa imaginação criadora, absorve toda a nossa atenção, satisfaz nosso sentimento da verdade e da fé e todos os elementos da nossa disposição interior” (idem, p. 313). Trata-se da escolha de um nome: "O nome que lhe der será extremamente significativo”; "Vocês já sabem como é importante escolher o nome para o superobjetivo” (idem, p. 314). A nomeação incide: "É o mesmo que comida e bebida para nós, em nossa função de artistas" (idem, p. $312)$.

Essa linha interior de esforço, que guia os atores do começo ao fim da peça, nós a chamamos a continuidade ou ação direta. Essa linha de um extremo ao outro galvaniza todas as unidades e objetivos pequenos da peça, encaminhando-os para o superobjetivo (idem, p. 287-288).

O superobjetivo pode situar o foco, enquanto toda uma cadeia subjacente é despejada.

Continue com isto até ter posto em jogo todos os seus elementos e depois escolha um deles. Escolha o que mais lhe atrair agora. Se conseguir fazer com que esse único elemento funcione concretamente, todos os outros virão atrás, atraídos por ele (idem, p. 280).

Enfileirados, os objetivos menores se constituem como "iscas apetitosas", um "trilho" (são termos de Stanislavski). As imagens acústicas não estão, necessariamente (às vezes, sim), presentes em escuta, mas o eco da sua incidência está impresso no

\footnotetext{
5 A presença de uma contradição é apontada por Brecht como um dos procedimentos que ele acha interessante no trabalho de Stanislavski: ao representar um bêbado o ator trabalha não o estar bêbado mas a ação "disfarçar a bebedeira". Ver em: JIMENEZ, Sérgio. El Evangelio de Stanislavski Según sus Apóstoles, los Apócrifos, la Reforma los Falsos Profetas y Judas Iscarlate. México: Editorial Gaceta, 1990.
} 
corpo. O arranjo conta, também, com o que oferece resistência a esta cadeia: a contraação. "Ao lado da ação principal, encontramos, opondo-se a ela, a contra-ação. Isto é bom, pois o resultado inevitável é mais ação. Precisamos deste choque de propósitos bem como de todos os problemas a resolver" (idem, p. 291). Ao situar o foco na contraação, a cadeia de ações é atualizada fora do foco, implicando o frescor; algo que se deu no corpo à revelia da vontade.

Os relatos de Toporkov trazem exemplos do trabalho a partir das artes plásticas para organizar a disposição dos atores pelo palco. Nos relatos de Knébel encontramos o ator trabalhando a partir do enquadre do corpo com um desenho para, em seguida, "justificá-lo", de maneira a produzir enquadre ficcional. Há relatos específicos onde o tempo-ritmo adquire valor. A pedagogia de Strasberg enfatiza a instrução do relaxamento e propõe procedimentos para que o ator o constitua como algo já impresso - que retorna em cena. A plasticidade da voz, diferenças de acento, desenho, tonalidade; detalhes dos objetos; a plasticidade do cotidiano; a dinâmica e o ritmo; perguntas feitas a si mesmo (o jogo do ator com o seu próprio pensamento); a voz da direção; a regra de jogo "relaxar a musculatura"; o sentimento de solidão em público: "Um teatro cheio de gente é, para nós, uma admirável tábua de ressonância. Milhares de correntes invisíveis de simpatia e interesse refluindo sobre nós.” (idem, p. 277). O ator situa-se, enquadrado pela plasticidade da sua relação com a poética cênica onde está inscrito.

O material inscrito no contexto da criação da obra particularmente interessa ao ateliê, por ser estrutural. O texto de bastidor para uma composição corporal é estrutural. Pedagogias como a de Laban, Chekhov ou Decroux implicam uma complexa rede de significantes para a inscrição do corpo na sua poética, com a nomeação de qualidades e a invenção de termos, cuja incidência no corpo se fixa com a repetição. Em Stanislavski encontramos o significante "sentimento de solidão em público". A construção faz parte dos bastidores da práxis stanislavskiana. Em outras práxis, são outras construções de bastidor, mas o lugar da palavra não enunciada, que implica a inscrição do corpo em uma poética específica, está evidenciado. O quanto esta é detalhada, é uma questão de modalidade; como é fixada, é uma questão de procedimento. Evidencia-se a incidência de diferentes materiais enquanto um deles funciona concretamente, situando o foco. Em um momento, é o sentimento de solidão em público. Em outros momentos, a incidência deste significante entra, no jogo, fora de foco.

Os bastidores são um campo de extração quando a fala faz incidência (dos colegas ou da direção), tal como um espetáculo de Bausch (de onde movimentos são 
extraídos). $\mathrm{O}$ ator encena efeitos de incidência, enquadrando-os na cena, inscrevendo-se na cena. Já o escritor sofre incidências, mas não as enquadra (organiza) na cena. Um poeta também utiliza anteparos, suportando, no corpo, os efeitos de suas reverberações, como atesta Ferreira Gullar: "Para você passar meio ano escrevendo um poema é preciso que você esteja tomado realmente por alguma coisa. (...)” (GULLAR, 2011, p. 141).

Eu não fazia outra coisa, saía para fazer compras e o poema estava na minha cabeça. Quando chegou em determinado momento este estado poético, vamos dizer assim, cessou (...) Um belo dia me veio uma frase do Hegel citada por Lênin (...) "No ramo da árvore estão o universal e o particular" (...) Me veio o final do poema: "O homem está na cidade como uma coisa está em outra coisa e a cidade está no homem que está em outra cidade" ${ }^{\text {. }}$.

Uma frase do Hegel pode ser um anteparo para a criação de um poema. Sobre "Na Vertigem do Dia", Gullar diz:

Um dia antes do seu $57^{\circ}$ aniversário, a escritora Clarice Lispector morreu (...) Estava um dia lindo: sol, árvores balançando com a brisa. Achei chocante, um contraste. Eu triste com a morte dela e a natureza nem ligando. O poema é isto.

Percebe-se certa propriedade do anteparo: a anterioridade lógica em relação à nova produção, que nasce. A morte de Clarisse; a imagem das árvores balançando com a brisa; uma frase do Hegel: são anteparos para a criação de Gular. Um poema pode ser um anteparo para mim, atriz; de outro ou meu: um poema que eu crio (cuja inspiração é a poética cênica, onde uma imagem do corpo é anteparo). Como esta descrição de Ciane Fernandes sobre uma cena de Pina Bausch.

\begin{abstract}
Ela toca seu próprio umbigo, diferentes pontos dos seios, ventre, rosto e topo da cabeça, como se tentasse sentir-se; a mão esquerda belisca o pulso direito, as mãos vão até o topo da cabeça e a esquerda empurra o antebraço direito para baixo. Corre então de volta a esquerda baixa, pausa como antes, sendo seguida por Minarik. Assim que Minarik toca seus ombros como antes, ela cai, rola para sua direita, para sua esquerda, levanta-se de frente para o auditório, e recomeça a sequência de arcos com os braços no mesmo local de antes. Atrás dela Minarik aproxima-se vagarosamente e toca sua cintura; ela completa a seqüência e corre de volta a direita baixa, e dança sua seqüência de autocarícias como antes ${ }^{7}$.
\end{abstract}

A descrição de corpo funciona como uma rubrica, anteparo-palavra que o ator cria. Perceber que a incidência está implicada no manejo das palavras pelo poeta nos

\footnotetext{
${ }^{6}$ Depoimento de Ferreira Gular sobre "Poema Sujo". Fonte: Revista Bravo, no. 158, p. 6-27.

7 FERNANDES, C. Pina Bausch e o Wuppertal Dança-Teatro: Repetição e Transformação. SP: Annablume, 2007.
} 
permite pensar a particularidade do nosso ofício. A particularidade do nosso ofício é encena-las indo além delas, porque o corpo atualiza algo que não se sabe e a cena implica esta espécie de função do não saber. No ateliê, tiramos proveito da poesia implicada em uma descrição do corpo. É como se cada inscrição do corpo na poética cênica implicasse um efeito da linguagem (verbal, pois o verbo é anteparo e não uma tradução do corpo). As diferentes práxis contam com uma poética do verbo para suportar a inscrição do corpo em cena. Cada ateliê do corpo precisa construir a sua descrição poética, de maneira que esta sirva como anteparo. Assim, sou a autora de um poema que invento para sustentar a cena do meu corpo para o olhar do outro. É como se, neste poema, a impressão digital estivesse em potência. É preciso desdobrá-lo em encenação quando, transpassado pelo olhar do outro, o ator é bombardeado pelo eco de cadeias que perde de vista. Trata-se de preparar algo para vazar pelas bordas de um enquadramento cênico, a fim de constituir a plasticidade de um corpo invadido por incidências.

\subsubsection{Terra Fértil e Estrela Cadente}

O ator é transpassado pelos materiais de um enquadramento que é constituído em cena. Efeitos de incidência aparecem no corpo sem a intencionalidade. Há produção de singularidade que escapa à justificativa racional. Assombra-se com o que, do corpo, é feito. Não é incomum ouvirmos dos atores que são possuídos pelos personagens ou que estes entram no corpo ${ }^{8}$. Os depoimentos atestam a posição do ator transpassado pelas incidências. A título da transmissão da prática, Stanislavski ficcionaliza o seu exercício pedagógico, criando Tórtsov, diretor-pedagogo que problematiza as operações. Muitas vezes, quem assume a voz narrativa do relato é o aluno, como vemos no trecho abaixo.

\footnotetext{
"Considerem o fato de que, enquanto estamos em cena, mantemos incessante contato uns com os outros e, portanto, os nossos ajuntamentos recíprocos têm de ser constantes. Pensem na quantidade de ações e movimento que isto significa e calculem a proporção de movimentos subconscientes que eles podem conter! (...) Não é só quando nos ocupamos de um intercâmbio constante de pensamentos, sentimentos e ajustamentos que o subconsciente
}

\footnotetext{
8 Posso dar dois exemplos: Aracy Barabanian em entrevista a Jô Soares (TV Globo, programa “Jô Zonze e Meia”) falando sobre a atuação como Clarice Lispector; Simone Spoladore falando sobre a personagem de "Lavoura Arcaica" (Luiz Fernando Carvalho, 2001) no documentário sobre o filme. Fora isto, no que diz respeito ao trabalho do ator com o texto dramático, muitas vezes, encontro, nos alunos, a tendência de se relacionarem com personagens como se fossem espíritos a possuí-los.
} 
entra em ação. Ele também nos socorre noutras ocasiões. Vamos por isto à prova em nós mesmos: sugiro que durante cinco minutos vocês não falem sobre coisa alguma, nem façam nada." Depois desse período de silêncio, Tórtsov interrogou cada um dos alunos sobre o que se passara em seu íntimo, em que pensara e o que sentira durante esse tempo. Alguém disse que, por algum motivo, lembrara-se, de súbito, do seu remédio. - O que é que isto tem que ver com a nossa aula? - perguntou Tórtsov. - Absolutamente nada. Quem sabe você sentiu alguma dor e ela o fez lembrar-se do remédio? continuou - Não. Não senti nenhuma dor. - Como foi que uma idéia dessas pulou para a sua cabeça? Não houve resposta. Uma das moças estivera pensando numa tesoura. - Que relação tinha ela com o que estamos fazendo? - indagou Tórstov. - Nenhuma, que eu saiba. - Você, talvez, notou algum defeito em seu vestido, resolveu consertá-lo e isto a fez pensar na tesoura? Não. Minha roupa está toda em ordem. Mas deixei minha tesoura numa caixa com umas fitas e tranquei a caixa em minha arca. De repente me passou pela mente: espero que eu não esqueça onde a guardei. - Então, você, simplesmente, pensou na tesoura e depois raciocinou sobre a causa? - Sim. Eu de fato pensei primeiro na tesoura. - Mas ainda não sabe de onde surgiu a idéia? Prosseguindo em suas investigações, Tórstsov descobriu que Vassili, durante o período de silêncio, estivera pensando num abacaxi, ocorrendo-lhe que a sua casca escamosa e as suas folhas pontudas o tornavam muito semelhante a certo tipo de palmeira. - O que pôs um abacaxi no primeiro plano do seu cérebro? Comeu algum estes dias? - Não. - Onde é que vocês todos foram buscar esses pensamentos sobre remédios, tesouras e abacaxis? (...) Todas estas coisas saem do subconsciente de vocês. São como estrelas cadentes. (STANISLAVSKI, 1989, p. 250-251)

A associação com a imagem acústica é evidenciada, mas não em uma relação direta, linear ou causal entre o que a situação-dada implica e o que o corpo atualiza. A metáfora da estrela cadente é utilizada para a associação que invade o foco, "como se caísse do céu", como se "riscasse o cérebro" (termo que aparece várias vezes). O ator não tem tempo de evitá-la. Trata-se da "fração infinitesimal" (idem: 252) do tempo. Algo que escapa à justificativa é atualizado. Desenvolvendo a metáfora de Stanislavski, diríamos que: "a terra fértil não se justifica na relação com a estrela cadente que nela cai”. No entanto, Stanislavski sai em busca de um elo perdido entre a estrela e a terra (de uma justificativa da impressão digital) e acaba propondo que, nos ajustamentos, tanto a ideia que risca o cérebro quanto o aparece no corpo, passam pelo inconsciente.

Ainda não compreendi por que você, enquanto nos falava sobre aquele abacaxi ficou se estorcendo e adotando umas atitudes físicas tão estranhas. Elas não acrescentavam nada a sua história do abacaxi e da palmeira. Estavam exprimindo alguma outra coisa. O que era? O que é que havia por trás da expressão intensamente pensativa dos seus olhos e do ar sombrio do seu rosto? Qual era o sentido do desenho que você traçou no ar com os dedos? Por que olhou tão significativamente para cada um de nós e depois sacudiu os ombros? Que relação havia entre isso tudo e o abacaxi? (...) Você deu uma forma física exterior à sugestão feita pelo subconsciente? Em qualquer destes casos, tanto quando teve a idéia do abacaxi, como quando se ajustou a essa idéia, passou por essa região desconhecida do subconsciente. Devido a um estímulo ou outro, uma idéia vem a sua cabeça. Naquele instante ela atravessa o subconsciente. (...) Quando tanto a idéia como seus 
pensamentos sobre ela são postos em forma física tangível, você passa mais uma vez (durante uma fração infinitesimal do tempo) pelo subconsciente. Cada vez que faz isso os seus ajustamentos, quer no todo quer em parte, absorvem dele algo de essencial. (idem)

Stanislavski afirma que não utiliza o termo "inconsciente" com rigor, mas na medida em que "incita a sua imaginação" (Stanislavski, 1989). De qualquer forma, ele acaba por testemunhar que a relação entre anteparo e impressão digital não é causal. $\mathrm{O}$ ator não controla a digital e nem as associações. Tanto a imagem acústica (o significante isolado) quanto uma impressão digital singular, implicam a instantaneidade que não dá tempo para frear (de maneira que se evidencia a necessidade do enquadramento). A atualização, no corpo, não se dá como consequência de uma associação interna, mas encontro. As incidências estão, no arranjo (no mesmo acorde), com o que a resultante corporal implica de contingência e isto torna cada criação singular. Não se trata de uma determinação da causa (da relação direta), mas de tessitura atravessada por linguagem e gozo a um só tempo. Trata-se, então, de incidir nesta tessitura, para provocar uma forma de gozo (um "jeitão"), de maneira que o aluno descubra um estilo de atuar ao mesmo tempo em que acontece a inscrição em uma poética. Escolhemos materiais para incidir, mas não temos o controle sobre o que aparece. A justificativa entre incidência e a produção corporal torna-se inútil, a não ser que o discurso produzido seja mais um campo de extração de materiais. Ao perguntar "O que você quer com isto? Por que você está fazendo isto?”, Stanislavski provoca uma resposta - e esta faz incidência.

\footnotetext{
Lembram-se quando Sônia me persuadiu jeitosamente a não forçá-la a fazer o exercício e como repetia várias vezes, as mesmas palavras, usando uma grande variedade de adaptações? Quero que vocês façam a mesma coisa como uma espécie de exercício. (...) Calma, excitação, bom humor, ironia, zombaria, belicosidade, censura, capricho, desdém, desespero, ameaça, alegria, benignidade, dúvida, assombro, expectativa, fatalidade (...) - Ponha o dedo sobre qualquer palavra dessa lista e, seja qual for, use-a como base para uma nova adaptação. (...) Ponham nessa lista qualquer outra característica ou humor humano que quiserem e verão que todos eles servirão para lhes proporcionar novas cores e tonalidades para quase todos os intercâmbios de pensamento e sentimentos (idem, p. 254-255).
}

Stanislavski testemunha que o foco circula entre imagens acústicas e visuais internas e articulam outras, já vincadas.

Dê o sinal, abra o caminho, e os seus raios e correntes se despejarão. Em cena, todas as circunstâncias dadas foram previamente preparadas, seus objetivos foram fixados, suas emoções amadurecidas e prontas para atender 
ao sinal, vindo à tona. Bastará um leve impulso e os sentimentos preparados para seu papel jorrarão, num fluxo contínuo (idem, p. 237)

Ao mesmo tempo, há os enquadramentos: fixos em cena ou os que precisam ser atualizados pela massa corporal viva (movimento, fala externa, sonoridade vocal). As associações se dão aos saltos e implicam a subjetividade do ator.

\begin{abstract}
Com quem ou com o que, você está em comunhão neste instante? Vassili estava tão absorvido em seus próprios pensamentos que não reconheceu imediatamente o teor da pergunta. (...) Desculpando-se, assegurou a Tórtsov que, se ninguém estava falando com ele, nem olhando para ele, ele não podia estar em contato com ninguém. (...) - Quer dizer - indagou - que uma pessoa, para estar em comunhão com você, tem de olhá-lo ou falar-lhe? Feche os olhos e tape os ouvidos, fique em silêncio e procure descobrir com quem você está em comunicação mental. Tente descobrir um instante ao menos em que você não esteja mantendo contato com um objeto qualquer. Eu mesmo tentei fazê-lo e visualizei o que se passava dentro de mim. Visualizei a noite precedente, em que tinha ouvido um famoso quarteto de cordas e segui meus movimentos. Fui ao foyer, cumprimentei alguns amigos, achei meu lugar e observei os músicos afinando os instrumentos. Começaram a tocar e eu escutei. (...) A música predispunha-me a toda sorte de imaginações. Pensei nos meus vizinhos, nos meus parentes que moram noutras cidades, longe, e em meu amigo morto (idem: 212)
\end{abstract}

\title{
4.2. A Transformação do Material do Pré-jogo
}

É o dizer que dá ao desejo seu lugar,
pequenos monstros cheios de vida

(Marcus André Vieira)

\subsubsection{Pina, Nelson, Kieslowski e Eu}

Chamei a cena resultante de "Pina, Nelson, Kieslowski e eu: Cada hora é um, gente que coisa doida!". Esta cena foi apresentada no TUSP na "Mostra Espetacular do CEPECA" de 2010. Misturei materiais de diferentes campos de extração, inclusive o discurso pedagógico - que entrou no pré-jogo e acabou sendo dito em cena (frases como "esta ação não estava aqui, apareceu agora"). Gosto desta música; deste vestido; sou apaixonada por este texto, ele faz incidência sobre mim, eu o coloco no arranjo - para, "sem querer" (entre aspas porque existe construção) descobrir a resultante. Constato $a$ posteriori que a música da trilha sonora de "A Liberdade é Azul" (Kieslowski) implica 
uma figura do vazio (lembrando as figuras do objeto $a$, segundo Dunker, o vazio, o excesso apontando para a falta, a tematização das bordas do quadro e dos limites da forma, a descrença no olhar). A dissonância cria: uma não resposta. Posso articular, também, a posteriori, que o corpo (que eu buscava na época) implica o excesso assim como a outra música do arranjo com fortes acordes ritmados no piano. Isto, eu articulo $a$ posteriori. No começo foi: desejo. A palavra desejo faz diferença, por seu quê de subversivo ou sua forma de demanda, que pulsa, gera impulso.

Não era a saga da autora de folhetins da década de quarenta que me interessou. A mãe se matar por causa do amante e o pai pela humilhação; a menina-moça ficar sob a tutela da avó e ser forçada a casar-se com o responsável pela tragédia familiar: não foi a fábula. Tornar-se cúmplice do tio de criação, que a ama. Uma estrutura folhetinesca. $\mathrm{O}$ que me estimulou foi uma posição histérica, que ora quer, ora não quer, que seduz e nega. O que encantou foi a falta de desejo; evidência da posição de objeto em resposta ao desejo do outro. E a fantasia da garota que se depara com o proibido; a ambiguidade do ódio excessivo do amante da mãe e, tal como Nelson borda, a rivalidade - vista pelos olhos da menina - quando a mãe aparece tanto como bruxa quanto como mulher fatal, ideal, inatingível. A fantasia da menina era o tema da obra. Aos poucos fui descobrindo outros temas.

Simplesmente, eu ia folheando as páginas do romance e pegando o que "batia": se o trecho me entusiasmava, eu escolhia. Sempre começo um processo assim: a escolha dos fragmentos pela incidência, fora de ordem. Pouco a pouco, se juntam. Aos poucos, com a escuta das cenas, vou tecendo uma interpretação - sempre a partir da produção cênica. A abordagem do texto é pela repetição da escrita e improvisação com materiais. $\mathrm{Na}$ época, eu soube da história do Robert Wilson - que escolhia as coisas assim: "quero um sapo" - sem saber o porquê. Deixem-me amar este objeto, incorporá-lo, torná-lo meu. Se a arte é tecida de encontros, haveria um deslocamento, uma junção, em um arranjo, onde, em algum momento, este se juntaria a outros e, feito lanterna mágica, eu poderia escutar o canto de uma poética - por montagem. Neste momento, entrou em jogo o teatro pós-dramático de Pina Bausch. A partir de palavras; descrição de corpo por Ciane Fernandes.

Ela toca seu próprio umbigo, diferentes pontos dos seios, ventre, rosto e topo da cabeça, como se tentasse sentir-se. A mão esquerda belisca o pulso direito, as mãos vão até o topo da cabeça e a esquerda empurra o antebraço direito para baixo. Corre então de volta a esquerda baixa, pausa como antes, sendo seguida por Minarik. Assim que Minarik toca seus ombros como antes, ela 
cai, rola para sua direita, para sua esquerda, levanta-se de frente para o auditório, e recomeça a sequência de arcos com os braços no mesmo local de antes. Atrás dela Minarik aproxima-se vagarosamente e toca sua cintura; Ela completa a seqüência e corre de volta a direita baixa, e dança sua seqüência de autocarícias como antes. ${ }^{9}$

Uma cadeia verbal descreve os movimentos corporais e, ao descrevê-los, evoca algo que não está presente - abrindo espaços. A descrição de corpo é memorizada pela repetição da escrita junto às falas externa e a interna (os três elementos misturados). No improviso no CEPECA, as impressões digitais implicam um erotismo que não havia. Outras ações são construídas, diferentes das que estavam descritas.

\section{PRÉ-JOGO MEMORIZADO}

Tocou o seu próprio umbigo

Minarik toca a sua cintura

Assim que toca seus ombros ela cai

\section{O QUE OCORREU EM CENA}

Levei a mão ao sexo

Coloquei a mão na cintura: típico trejeito feminino

Estapeei meu rosto várias vezes e caí de costas no chão

Tabela 1: Transformações do pré-jogo durante a experimentação cênica

$\mathrm{O}$ que provocou as mudanças? Mesmo que a posteriori possa interpretar a cena, não é possível precisar. Reconhece-se que o vetor "anteparo - impressão digital" implica uma área de vulnerabilidade, onde se instala algo que escapa ao controle e aparece pela tessitura corporal. Mas podemos tentar formalizar a operação; detalhar as associações que as impressões digitais evocaram e que, instantaneamente, entraram no arranjo, ajudando a ultrapassar o limite da visualidade implicada na cadeia memorizada.

O movimento "rolar para cá e para lá" evocou a imagem de uma boneca; e a frase de Clarice Lispector "ela é jogada de um lado para o outro" (de um espetáculo de 1997) ${ }^{10}$. Também a imagem da replicante (loira) no filme "Blade Runner" (Ridley Scott, 1992): a atriz Daryl Hanaah atingida por tiros e se debatendo no chão (que assisti repetidas vezes na juventude). A escuta da cena inscreve novos materiais e provoca o agravamento, a definição da ação. Em uma fração infinestesimal "estrelas cadentes" aparecem - diz Stanislavski. Ecos, estilhaços, estão no eixo vertical de uma memória de vida. São disparadas. A reverberação implica algo residual no corpo, mas também, algo no olhar.

\footnotetext{
9 FERNANDES, C. Pina Bausch e o Wuppertal Dança-Teatro: Repetição e Transformação. SP: Annablume , 2007.

10 O espetáculo "Quatro Vestidos Vestem Clarice" dirigido por Glaucia Felipe no Departamento de Artes Cênicas por ocasião de uma pesquisa de iniciação científica. Utilizamos contos de Clarice Lispector. Esta frase é do conto "O Búfalo". Ver: LISPECTOR, Clarice. Laços de família: contos. Rio de Janeiro: Rocco, 1998.
} 


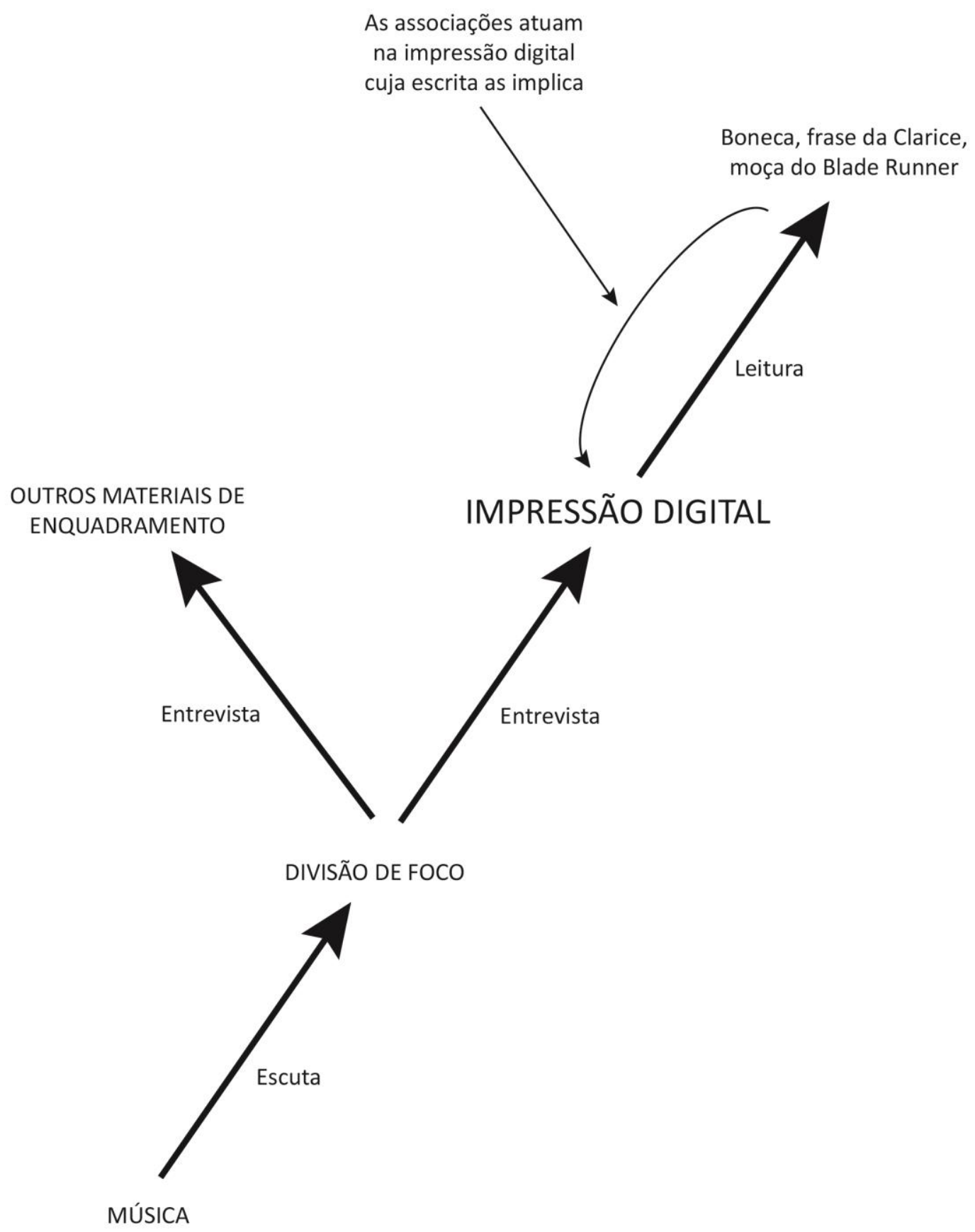

Figura 97: Formalização das associações que acontecem em cena Obs. A palavra "entrevista" está sendo utilizada com o sentido de "ver de relance"

Em cena, conto com o jorro da incidência do pré-jogo (memorizado com a repetição da escrita) em alternância com outros materiais; uma espécie de movimento de ir e voltar (iô-iô). A sucessão de alternâncias vem como uma cascata (precipitação): a descrição de corpo, mas, algo a mais. Este algo a mais (outra cadeia) seria um resíduo das reverberações da escrita? Surge em cena. Mas havia sido encenado, em súbitas e 
instantâneas associações, na escrita? Ou se trata de algo que surge do embate com o enquadramento (espaço-temporal) no instante da cena? Ou, nesta produção, estaria implicado o diálogo com a cultura teatral - de maneira a escutar "vozes"? Vozes que me inscrevem em uma poética cênica, que implica um conceito de teatro a qual respondo (e por isto "vou além")? A ânsia da inscrição em uma experiência estética conta. Há desejo: surpreender e trazer, à cena, o excesso como um dos princípios do trabalho. Em alguns momentos, trata-se de um a mais e, em outros, de um a menos. A falta de algo que está na descrição de corpo deixa um espaço - que é preenchido com a nova ação. Quando coloco a mão na cintura (com um trejeito feminino), na descrição de corpo está: "Minarick (bailarino de Bausch) coloca a mão na cintura". Trata-se de "resolução de problema”. Em um dos espasmos do piano (música em cena), o braço direito se desprende e vai ao rosto, estapeando-o. Na descrição está: “A esquerda empurra o antebraço direito para baixo”. A produção cênica promove o surgimento de outra cadeia (uma criação), mesmo que a pré-programação esteja em jogo. É como se a mão do homem me estapeasse. Está em jogo a incidência do romance de Nelson Rodrigues com a fantasia de ser surrada? Mesmo que se perca de vista as cadeias associativas, é evidente o princípio do arranjo e atualizações "sem querer" - porque o gesto não foi planejado (surgiu na hora). "Sou jogada de um lado para outro" (associação com o texto de Lispector): por acaso não se pode ler a posição de objeto implicada na frase? Há fantasia acionada por este anteparo? Uma série de associações me enlaça ao universo rodrigueano. $\mathrm{Na}$ escrita, se misturam à plasticidade das visualizações: a liberdade diante do mar; um "eu-menina" correndo; a descoberta do sexo; a infância na praia de Canasvieiras; relações sucessivas "mulher e homem", permeadas de agressividade (fantasia ou memória)? O que a frase "procurando sentir-se" implica quando repetida diversas vezes no procedimento da escrita? Que tipo de impulso? Quais reverberações? Dependendo das palavras que se usa no pré-jogo, de como montamos nosso poema corporal, provoca-se. É evidente a perspectiva do manejo da área de vulnerabilidade sem que tenhamos o controle do que vai aparecer. A pretensão não é o controle; mas confiar em algo que ali reverberou (e será atualizado), com a margem do novo, para a invenção instantânea, onde um estranho (ao meu olhar) se inscreve. 


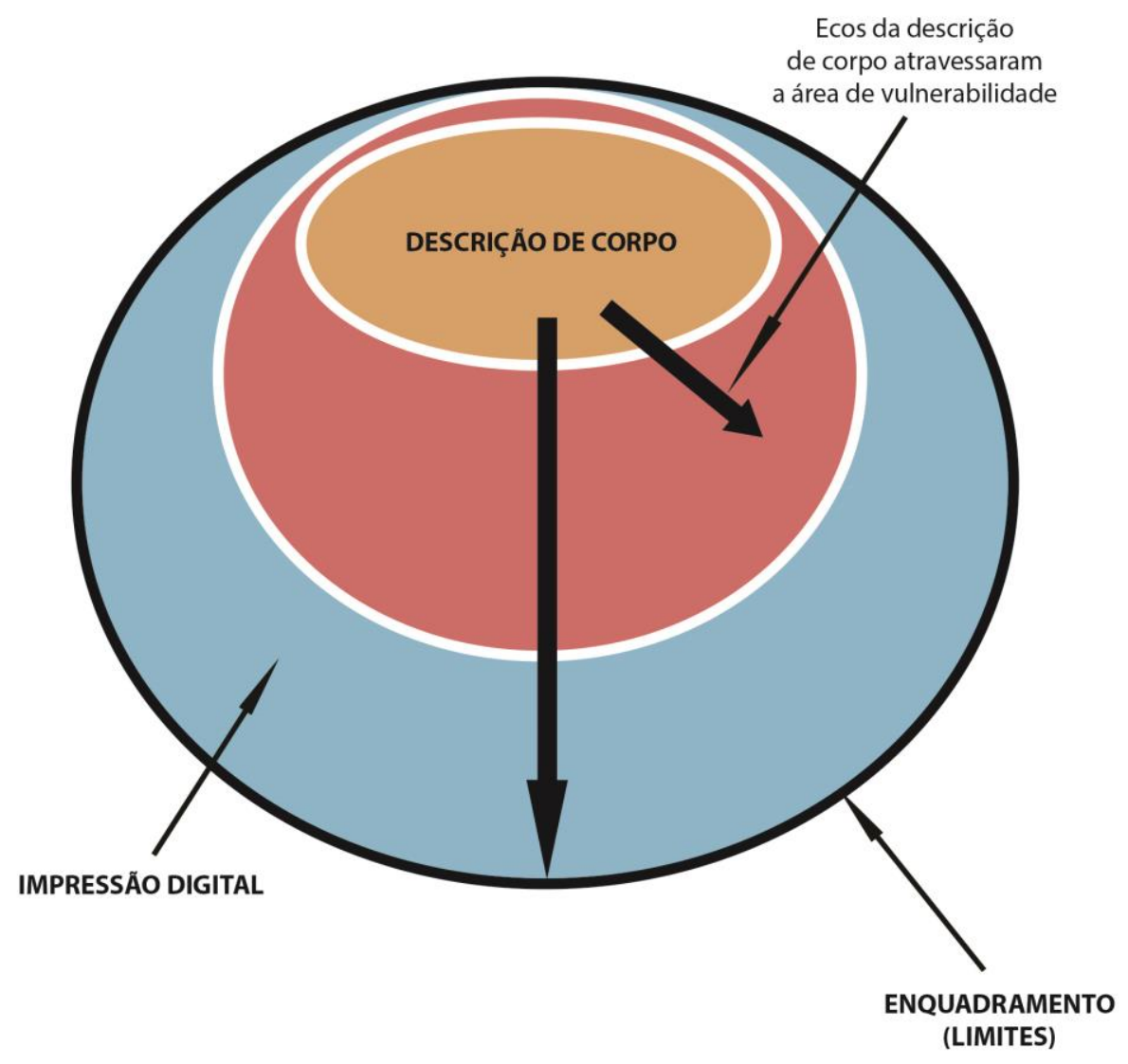

Figura 98: Incidência da descrição de corpo na área de vulnerabilidade

Além do desenho do corpo, criado no instante, o espaço cênico define limites: uma parede ao lado; na frente, os espectadores: são anteparos de enquadramento, assim como a roupa. Uma camisola branca e sapato alto preto (evoca os figurinos de Bausch). A agressão erótica que permeia a obra rodrigueana (e talvez as memórias da atriz ou a sua fantasia) se une à visualidade de uma cultura de agressões à mulher, que começa a aparecer. Ou uma "cultura do palco": a inscrição em uma poética que implica o corpo como um território de atravessamentos e o eu como objeto do sujeito ${ }^{11}$ - tematizado na obra. Caio para trás. O movimento da "queda", que exercitei durante muito tempo em aulas de Martha Graham ${ }^{12}$ retorna. A queda, sem a precisão que deveria ter se estivesse na aula de dança; queda inscrita na visualidade da ficção que a deforma, mas dotada de plasticidade própria. O movimento cujo eco vive no corpo. Observei deslocamentos e

\footnotetext{
${ }^{11} \mathrm{O}$ "eu" (enquanto imagem) como objeto (e não como "sujeito") é uma ideia explorada por Lacan de modo que haveria o "eu do sujeito" - sujeito que não é o "eu”, mas efeito da linguagem, um lugar de "falta a ser' que a linguagem implica. Ver: LACAN, J. O Seminário - Livro 4: As Relações de Objeto. Rio de Janeiro, Jorge Zahar, 1965.

12 Estudei Martha Graham com Penha de Souza, Cassia de Souza, Claudia de Souza e Jussara Terrats.
} 
repetições do significante "queda" durante todo o processo: desta cena para outra, em que a personagem narra a morte do pai; para outra, em que narra a descoberta do amor; alojando-se quando enceno a perda da percepção do corpo (e lá ficou).

Durante a Memorização Através da Escrita surge uma fala interna: "Cada hora é um gente, que coisa doida!’. Esta fala implica a visualidade da situação ficcional, mas é fala criada em nome próprio. Conta com a interpretação da atriz (engendrada de forma pessoal): Suzana responde ao desejo de vários homens. Este material verbal é incluído no pré-jogo, que conta com duas cadeias. Uma das cadeias é contra-ação da outra: "Cada hora é um, gente que coisa doida!" e a descrição do corpo.

\begin{abstract}
Cada hora é um, gente que coisa doida! / Ela toca seu próprio umbigo, diferentes pontos dos seios, ventre, rosto e topo da cabeça, como se tentasse sentir-se / Cada hora é um, gente que coisa doida! / A mão esquerda belisca o pulso direito, as mãos vão até o topo da cabeça e a esquerda empurra o antebraço direito para baixo / Cada hora é um, gente que coisa doida! ${ }^{13}$
\end{abstract}

Estas duas cadeias são como duas pernas. Diante dos alunos, pulo de uma perna para a outra, explicando que o ator pode se apoiar ora na "perna esquerda" ora na "perna direita"; pode ficar um bom tempo apoiado na "perna esquerda" enquanto brinca de movimentar a direita. A "perna esquerda" pode ser uma fala, que se repete internamente - causando incidência (como uma nota tocada, sem cessar, no piano). A "perna esquerda" pode ser a escuta silenciosa de uma canção - e conforme a música que incide, os movimentos da "perna direita" resultarão com uma qualidade ou outra. A "perna esquerda" pode ser uma sucessão de falas internas, cada qual provocando uma ação diferente, gerando progressão dramática. Tudo depende do arranjo.

No espaço cênico, como aquecimento, experimento variações do pré-jogo no corpo - jogando com a alternância entre diferentes qualidades físicas: grande, pequeno, rápido, intenso, leve, lento. Não há pré-fixação de um enquadramento plástico corporal, mas os impulsos da descrição em potência, para retornarem na área de vulnerabilidade. Os ecos da descrição, que são explorados em diferentes variações do desenho corporal. Com o atravessamento da música (o som do piano invade o foco), as reverberações da descrição de corpo vão sendo atualizados - e sinto-as brotar na tessitura corporal, com variações. A criação é experimentada apenas diante do olhar do CEPECA. A partitura surge enquadrada pela relação com este olhar.

13 Junção, no pré-jogo, das duas cadeias: a repetição de "Cada hora é um gente, que coisa doida!" e a descrição de corpo extraída de Fernandes. 
A fala oculta implica contra-ação, interrompendo várias vezes a sequência da descrição de corpo e, a cada retorno, inscreve-se novo impulso. A frase "Cada hora é um gente, que coisa doida!” escapa. A plasticidade da relação com o espectador enquadra: "estou dividindo, com eles, meu pensamento". As impressões digitais surgem nos instantes de troca: entre a fala oculta e a descrição de corpo (na fissura entre uma cadeia e outra). Mas, também, no interior da descrição de corpo: na troca dos materiais sequenciados ${ }^{14}$ : “Toca no seu próprio umbigo, diferentes pontos dos seios, ventre, rosto e topo da cabeça, como se tentasse sentir-se" (troca) "A mão esquerda belisca o pulso direito, as mãos vão até o topo da cabeça e a esquerda empurra o antebraço direito para baixo”. A instalação das impressões digitais coincide, também, com as trocas dos acordes do piano: novo acorde, novo impulso. São nas trocas que as impressões digitais se inscrevem.

14 No texto "Subpartitura e Texto-dado: A Troca para a Inscrição do Impulso", proponho o impulso como troca. O texto foi publicado nos "Anais da V Reunião Científica de Pesquisa e Pós-graduação em Artes Cênicas", em 2009. 
Ek Tocs se phopro theras difreutes ponks de sees lentre

nosto

e repo de colos
Fl, teaso

popmonubls
deferentes

wints

los seus -

leuthe

os 2

enopede coses

conorazelse

bulir-se

- Mpocacoles

es eoquerde

$\Delta m$

empura

anose

- vinlesrorso

teutare

derevto Isats

suctor-se

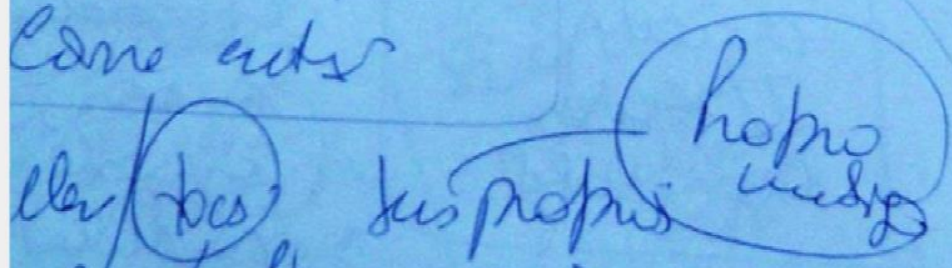

A mo

squene

Slusce

xins

opech

offeruts ponts des secels

enecto-

$\Delta s \mathrm{~m}$ in ath -

lonme

opropo de

nosto

cosep -

expactacobess

equequer
ipuly uns
ably, na.

Figura 99: Manuscrito com a Descrição de Corpo.

146 


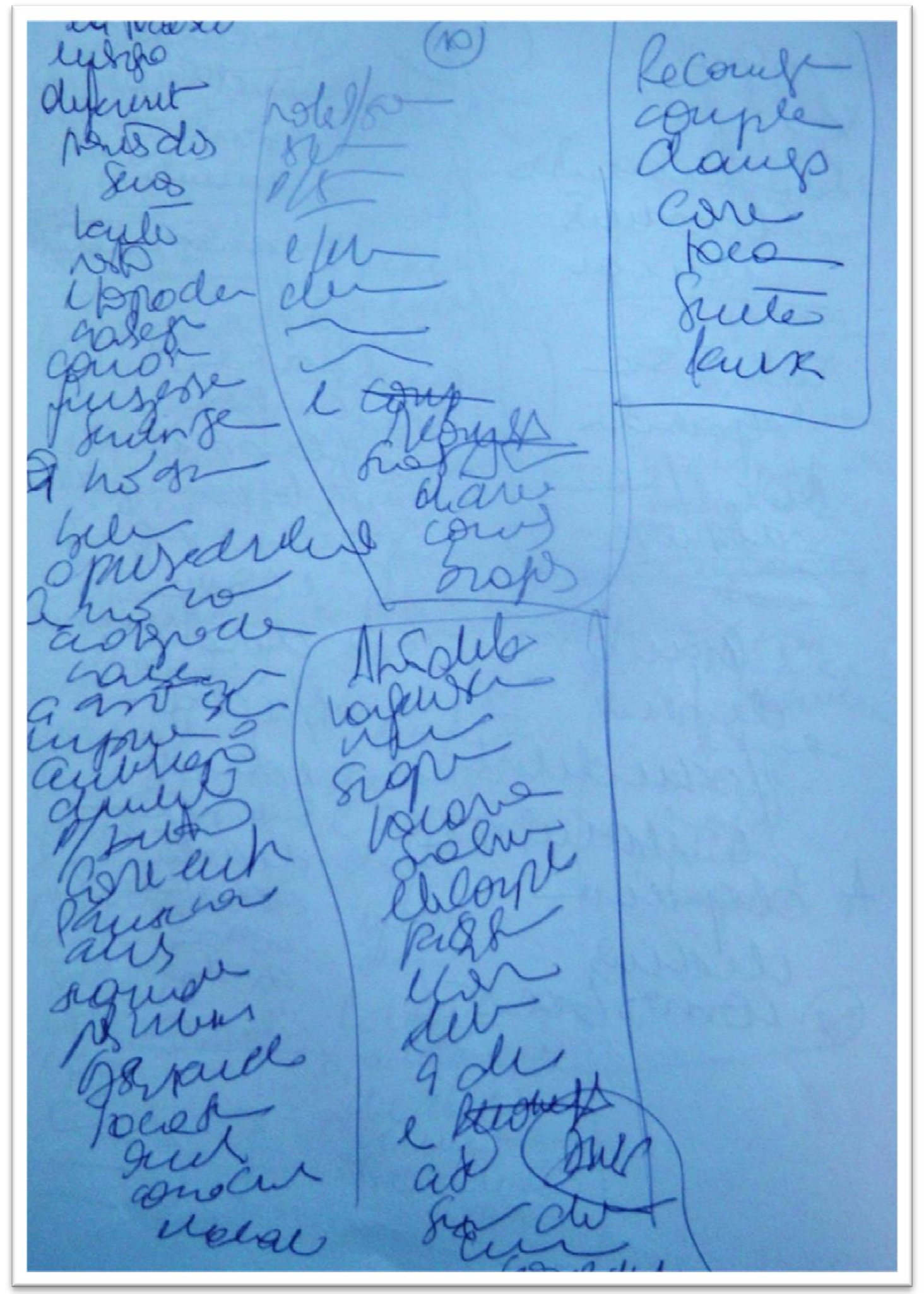

Figura 10o: Etapa da "Psicografia" 


\subsubsection{Um País de Órfãos}

Onde reina a simplicidade e a ordem não pode haver teatro nem drama, e o verdadeiro teatro nasce, como aliás a poesia, mas por outras vias, de uma anarquia que se organiza (Antonin Artaud).

A Figura da Avó:

A plasticidade da fábula faz incidência. Mas outras incidências dizem respeito à maneira de tecer uma cena e um diálogo com a cultura teatral: a figura da avó surge de uma mistura. Uma "penca de bonecas". A visualidade da vida da atriz: a avó cheia de netas, Rejane menina, as bonecas, a avó Sueli com os primos (a penca). Um diálogo com Silva: o objeto (um anteparo) dificulta o andar e produz a curvatura que caracteriza um "Quem" (Spolin). A avó precisa ser curvada; a vara das bonecas faz peso.

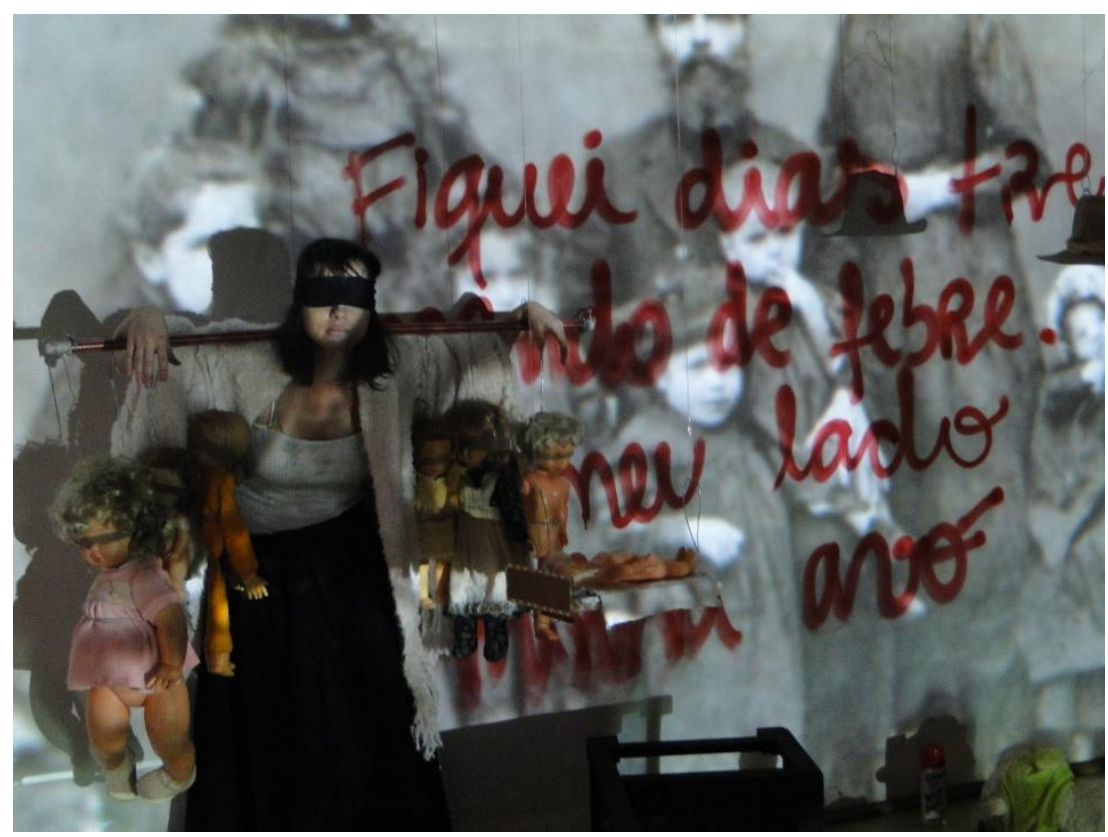

Figura 101:

A vara com bonecas.

A vara de bonecas surge também de meu desejo de trabalhar o anteparo-objeto da "Oficina da Essência". Trata-se de uma incidência que implica a inscrição em certa poética, que presenciei na graduação ou em mestrados fundados neste diálogo: as atrizes expunham os anteparos e a plasticidade dos arranjos externos fazia incidência em mim. O "Quem” (Spolin) “matriarca” está presente: um significante. Vão entrando outros 
"Quens" no jogo: "bruxa" (o romance rodrigueano evoca a plasticidade dos contos de fada); "anciã" (graças à interlocução no CEPECA). As impressões digitais vão se transformando com estes outros "Quens”. O arranjo vai engordando. Um "Quem” não elimina o outro. Eles atuam juntos.

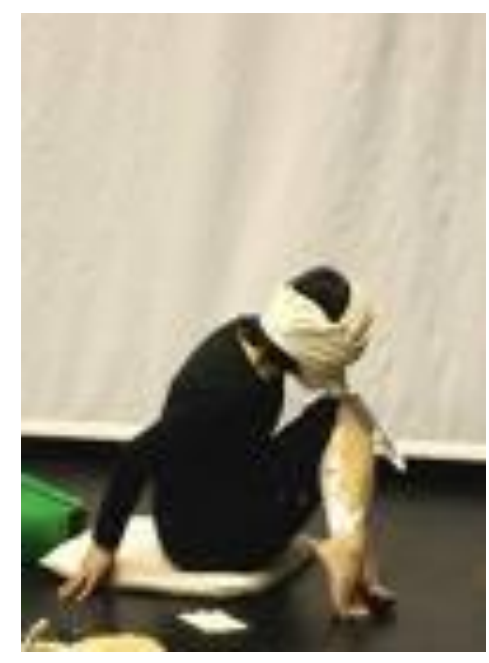

Figura 102: Stacy Makishi em "How Can I Show You My Love?"

A presença da venda vem da incidência da imagem (de uma performance): quero encenar esta incidência, mas não sei em qual arranjo encontro enquadre. Deparome com um novo anteparo (de mediação): caminhando pelas ruas, brinco com os dedos (tocando piano no ar) e, de repente, este gesto associa o tremor de um velho cego tateando o espaço. A presença da venda ganha o enquadramento da imagem da cegueira que, posta em cena, é interpretada pelos pesquisadores do CEPECA: "Ela não enxerga nada, não enxerga as necessidades da menina e nem o que acontece com ela"; "A avó pode ser cega. Isto não significa que não enxergue. Como Tirésias, cego é aquele que mais vê". Eles escutam significantes diferentes, que não estão inscritos no eixo horizontal da cena; eles produzem, associam, em uma cadeia vertical, a partir do seu próprio repertório, enquadrando a cena na sua plasticidade interna (com a plasticidade do seu olhar).

\section{A Fantasia do Varal:}

Antes de a avó colocar as bonecas nas costas, elas estão penduradas em um varal de arame farpado, associado a partir do desenho de uma cabeça rachada. Há seis 
anos eu vi, na internet, este desenho. A princípio, nada articula os materiais. A associação vem de súbito: descendo a Rua Augusta, depois de ter passado a tarde inteira na Livraria Cultura (procurando uma imagem de um quarto antigo que queria colocar em projeção, mas não a encontrei), invade o olhar, como um raio, junto à imagem da cabeça rachada, um varal "rachando" o espaço do teatro: enorme, com roupas íntimas penduradas, adentrando por quilômetros o campus universitário. Uma fantasia, uma cena, de onde extraio material. Reduzo o varal para dentro da sala do CEPECA; as roupas femininas são substituídas por "bonecas-gente-vendadas".

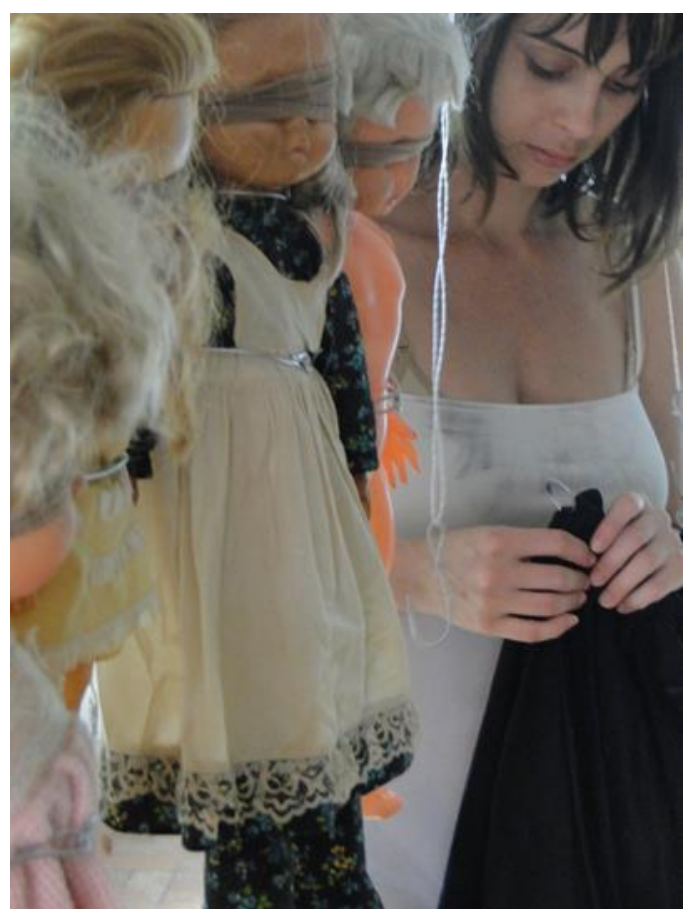

Figura 103:

Bonecas cegas

Vendada, "cato as bonecas" (termo no pré-jogo); os braços passando bem perto do arame. Ou foi por causa das cercas de arame farpado do sítio do meu pai? Ou porque Evinha Sampaio me disse: "Ela está doída, com o corpo todo de arame farpado"? Estas são articulações a posteriori. No entanto, não importa, a não ser que esta elaboração produza um campo de onde possa extrair novos anteparos. Não há razão, mas "causa" que me escapa. Naquele instante, há apenas uma incidência: a visualidade daquele arame rachando o espaço, muito grande, comprido, cheio de roupas íntimas penduradas. Potencializo os movimentos dos braços para dar a impressão de quase esbarrar no arame farpado. Tem dias em que me machuco, tal como aquela menina andando de patins e desafiando, a cada tombo, a resistência da pele sobre a carne exposta. O fato de estar cega transforma a cena em performativa: vivo a experiência de estar de olhos vendados 
ao invés de representa-la. Mas, ao mesmo tempo, represento a avó. Posso tirar a venda: é a escritora brincando de encenar seu mundo (de forma que encontro o enquadramento ficcional). Em “A Encenação Contemporânea”, Patrice Pavis propõe um híbrido, uma cooperação entre performance e encenação.

Esta aproximação é tão marcada que seria preciso quase criar palavras híbridas, como mise-en-perf ou performise. O diagnóstico desta contaminação é simples, não saberíamos, no momento, criar uma encenação sem a reflexão da performance theory, nem uma performance sem a possibilidade de se fazer uma análise semiológica e fenomenológica (PAVIS, 2010, p. 60)

O conceito de performativo normalmente faz oposição à representação, quando a cena torna-se um signo do universo ficcional que representa (oposição com a qual frequentemente nos deparamos na teoria teatral contemporânea). No entanto, estruturalmente, a representação implica, também, algo de performativo: de inacabado, do processo inscrito em cena, ou quando o seu ato é realizado no instante já e algo escapa à elaboração semiótica. Sobre a performatividade Fernandes diz:

(...) interessa apenas reter a afirmação de que a performance nunca é um objeto ou uma obra acabada, mas sempre um processo, por estar ligada ao domínio do fazer e ao princípio da ação. Quanto à performatividade, seria ao mesmo tempo uma ferramenta teórica e um ponto de vista analítico, já que toda construção da realidade social tem potencial performativo. A dedicação dos estudos da performance a variados aspectos da vida social tem contraponto nas análises voltadas especificamente para a arte da performance, desenvolvidas inicialmente por Rose Lee Goldberg e Jorge Glusberg e, no Brasil, de forma pioneira, por Renato Cohen. A despeito de terem emergido simultaneamente, no contexto contracultural dos anos 1970, os dois campos de pesquisa diferenciam-se. A performance art detém-se na instância artística, e não pode ser separada das práticas estéticas que passaram a se desenvolver em vários cantos do mundo no período, como o happening, a action painting, a live art, a arte conceitual e a body art. Interessada na experiência corporal e na ação do artista em situações extremas, a arte da performance visa exatamente a desestabilizar o cotidiano por meio da transgressão e da ruptura, promovendo ações artísticas marcadas pela diferença. A perspectiva ligada à arte da performance é mais produtiva para o estudo da teatralidade, pois, seguindo seus pressupostos, pode-se dizer que diversos traços performativos permeiam a linguagem do teatro contemporâneo. É o que defende a teórica alemã Érika Fischer-Lichte, ao considerar a performance uma extensão natural do campo do teatro, e não um novo paradigma, como quer Schechner. A ensaísta trabalha com exemplos extraídos exclusivamente do que se pode considerar a prática artística do teatro e da performance contemporâneos. Seguindo a linha européia de abordagem do tema, focaliza suas análises no trabalho de encenadores e performers como Frank Castorf, Einar Schleef, Romeu Castelucci, Marina Abramovich e Schlingensief, por exemplo. Por outro lado, concorda com ele quando afirma que a performance e o teatro contemporâneo são processos e não obras acabadas. Para Fischer-Lichte, o teatro experimentou um desvio performativo por volta dos anos 1960, que o transformou em evento, em 
lugar de obra acabada. A partir daí, não pode mais ser concebido como representação de um mundo ficcional que o público deveria observar, interpretar e compreender. Na verdade, a performatividade elide o escopo da teoria estética tradicional, pois resiste às demandas da hermenêutica de compreender a obra de arte. Para a ensaísta, entender as ações do artista é menos importante do que experimentá-las, fazendo a travessia do evento proposto. A participação nessa experiência provoca uma gama tão ampla de sensações que transcende a possibilidade e o esforço de interpretação e produção de significado, não podendo ser superada nem resolvida pela reflexão. Isso não quer dizer que, numa performance, não haja nada para o espectador interpretar. Mas também não se pode dizer que as ações do artista performativo apenas signifiquem alguma coisa. É evidente que tanto para a hermenêutica quanto para a semiótica, tudo que é perceptível em cena pode ser definido e interpretado como signo. No entanto, no caso da performance, a materialidade das ações e a corporeidade dos atores dominam os atributos semióticos. O evento envolve performers e espectadores em atmosfera compartilhada e espaço comum que os enreda, contamina e contém, gerando uma experiência que ultrapassa o simbólico. O resultado é uma afetação física imediata que, para a ensaísta, causa uma 'infecção emocional' no espectador. (FERNANDES, 2011, p. 16-17).

\section{A Escrita no Quadro Negro:}
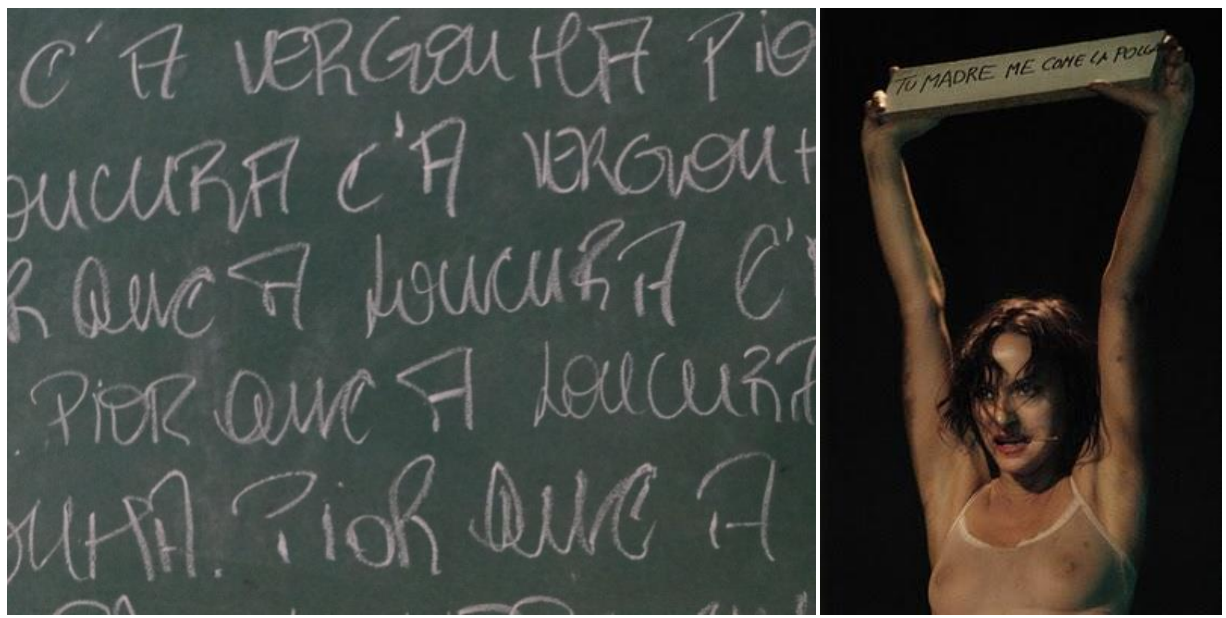

Figura 104: "Pior que a loucura é a vergonha" e Angélica Liddell

A grafia no quadro-negro. A incidência vem de uma performance da Angélica Liddell. Há incidência da plasticidade da grafia (como modalidade de enquadre) e, também, da frase escrita na plaquetinha: “Tu madre me come la polla”. Uma das chaves da minha interpretação sobre a ficção rodrigueana é a disputa entre mãe e filha - além de gostar da agressividade que a exposição da grafia pode implicar. Ela testemunha a presença de pensamento: escrever coisas que seriam difíceis falar (que só se pensa). Como "Entre nós a presença de uma morta" ou "Deus vai te castigar" (que picho na parede). O quadro-negro me lembra a infância: as aulas que eu dava para meus dois 
irmãos, Carolina e Gustavo. Ele já está lá, na sala do CEPECA e, portanto, é um encontro. A frase "Pior que a loucura é a vergonha" é enquadrada no espaço e no tempo cênico. A repetição implica um enquadramento temporal, uma cadeia disposta no tempo da cena.

Antes da Apresentação no CEPECA:

A fala da avó está misturada a rezas católicas. As duas cadeias são entrelaçadas para a memorização: reza, fala, reza, reza, fala, reza, fala, fala. O entrelaçamento é memorizado até a exaustão, para entrar em cena, na área de vulnerabilidade. Em cena, a voz ocupa o espaço sonoro e o tempo que levo nas ações. O percurso espacial a ser percorrido implica uma regra, um trajeto pactuado. O foco está na imagem acústica: "Eu preciso chegar até a caminha" (fala interna) - que, se divide com impressões digitais (que se precipitam).

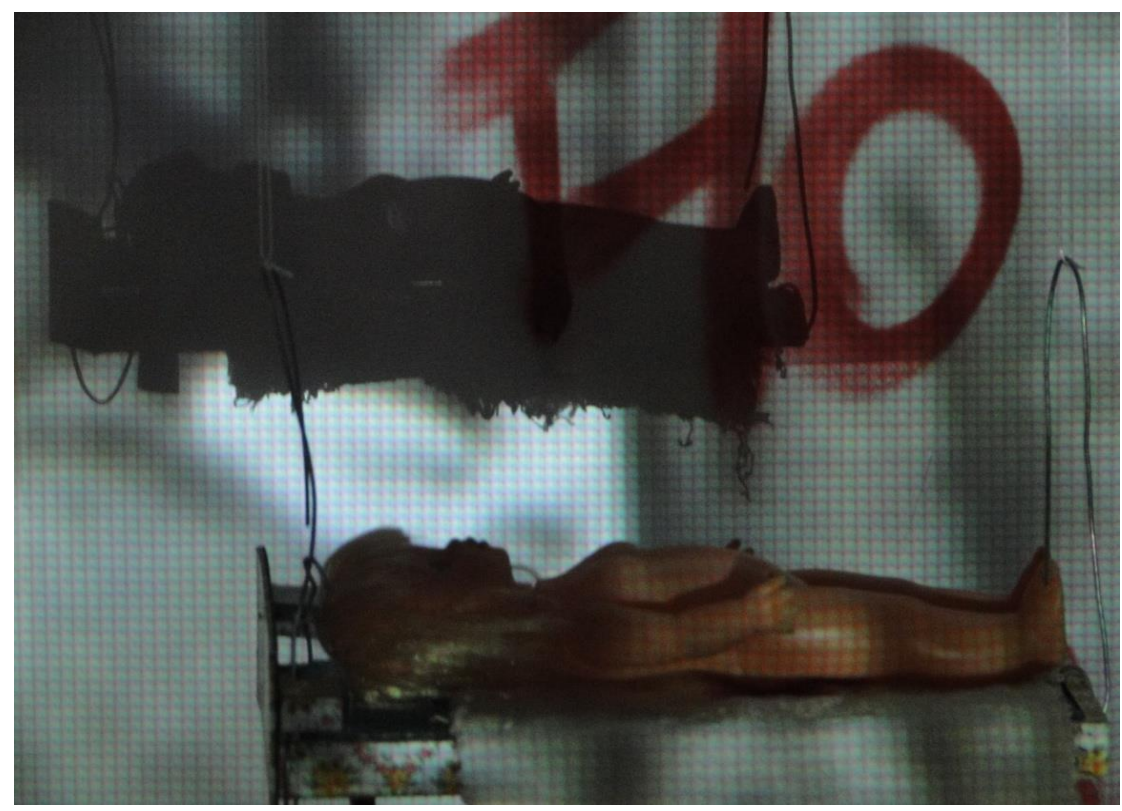

Figura 105: A menina acamada

Fala externa e percurso espacial percorrido - os dois se acomodam. As rezas e as falas se misturam. Estão memorizadas em ordem, mas entram como material plástico, desmembradas e bordadas de outro modo. Um pedaço aqui, outro pedaço lá, conforme os desdobramentos das ações o improviso com a situação, que faz incidência: prevenir as meninas sobre Aristeu (o tio), lamentar a vergonha das mulheres. $\mathrm{O}$ entrelaçamento 
entre rezas e as falas aparece na área de vulnerabilidade, mas com uma configuração um pouco diferente. É como se houvessem pequenas defasagens (em relação à intercalação anterior, que é desdobrada, desmembrada, refeita); deslizamentos de rezas sobre falas com trocas de lugares. Uma nova ordem "fala - reza" se acomoda no enquadramento espaço-temporal cênico.

A cena termina com a descoberta de uma mancha de sangue no lençol da menina (neta), representada pela boneca acamada (a ficção oferece um enquadramento para o objeto). O material utilizado para a ação de cheirar o pano é a imagem de um cantor de rock, em êxtase, agarrado ao microfone (o ar de insano). Não sabia onde se instalaria, até que veio a associação: a avó comemora que a menina está pronta para ser entregue ao homem (ex-amante da mãe, com quem a matriarca quer que se case). A aproximação da cama e o paninho sujo de sangue, que a avó cega cheira, são ordenados por um encadeamento de falas internas que exponho na sonoplastia para mostrar a sua presença, mas que, no começo, estava só no pré-jogo: “Toco. Tateio. O rosto. A testa. Toco. Tateio. O lençol. Seguro. A boneca. Puxo. Abro. A mão-pássaro”. Isto tem um ritmo. Este ritmo faz incidência e gera excitação. Antes de sonorizado e exposto, era oculto (e, como material oculto, sustentava a sequencia de impressões digitais). Depois que passa a enquadramento (preenchendo o espaço sonoro em torno do corpo), preciso de novo material interno para continuar atuando. Qual novo material instalar no préjogo para ocupar a casa da incidência oculta (presente na estrutura)?

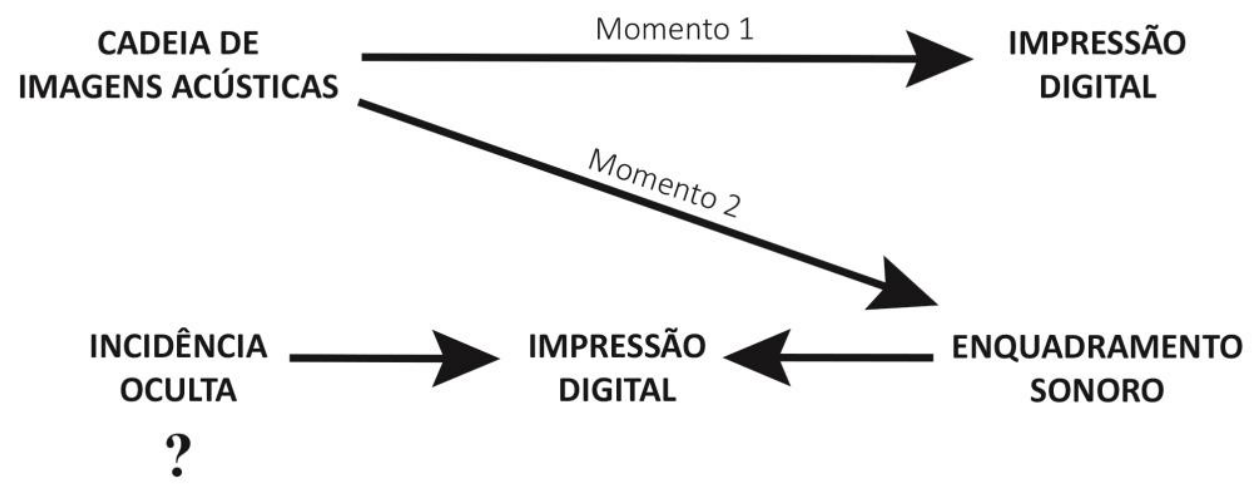

Figura 106: Um material oculto deixando vago o seu lugar 
Ponho avisos no pré-jogo. Assim, o que precisaria fazer força para lembrar é memorizado. Pode sair do foco. Eu não preciso ficar preocupada em: "Abra o paninho bem perto do rosto. Isto. Para o público perceber". São instruções de jogo, diálogos comigo mesma, uma espécie de autodireção; uma voz interna que me ocupa e incide (como se viesse de outro): "Quando o público entra eu estou aqui. Isso, você está envolvida com a ação". O que era diálogo de bastidor eu passo para a régua sonora a título de exposição. Mas não todos os materiais. Alguns diálogos comigo mesma (extraídos do bastidor e depositados no pré-jogo) se mantém como texto subjacente e testemunha o lugar de uma espécie de "monólogo interior".

Sobre o monólogo interior, Maria Knébel (atriz e assistente de Stanislavski) diz que são "palavras incomunicáveis em voz alta" (KNEBEL, 2005, p. 107) - e ainda: “(...) é preciso imaginar o monólogo interior. Não se deve sofrer com a ideia de que é necessário criar todos estes monólogos. (...) Necessitamos que estes pensamentos se tornem próximos e queridos para o ator" ${ }^{, 15}$ (idem, p. 108). A construção do pensamento da personagem é uma chave no sistema stanislavskiano. Mas, no caso da extrapolação de uma diegese (onde estaria inscrita a ideia de personagem), pode-se utilizar a noção de subpartitura (como uma ampliação do "subtexto"), tal como propõe Pavis: “(...) essa sólida massa branca imersa sobre a qual se apoia o ator para parecer e permanecer em cena, tudo aquilo sobre o que ele baseia sua atuação” (PAVIS, 2003, p. 89). No ateliê, nos dedicamos à palavra de bastidor para a composição do monólogo interior: uma voz que desenha o corpo; ou que provoca a incidência de coisas que desmancham o corpo constituindo uma dialética da construção e desconstrução da forma.

Entra a música do Purcell. Voz: "Minha avó era uma mulher antiga $e$ nervosa". Seguindo a voz, a corporifica. "Visivelmente cansada. As mãos carregadas de gestos. Os pés amarrados condicionavam o tamanho dos seus passinhos. A boca curvada para baixo em uma espécie de esgar de nojo. As pálpebras caídas". Por um instante a reconhece no próprio corpo. Abandona o que constituiu corporalmente e se desloca para a parede, com o spray nas mãos. Picha "Fiquei dias em febre" enquanto entra a grafia "Capitulo Três: Os Cuidados da Avó". Deita a boneca na caminha. Pega o microfone... "Ativa. As cochas duras apesar de velha e ágil apesar de cega". Senta a boneca na caminha, pega o microfone, tom de história infantil: Há alguns anos atrás, no leito de morte daquele que amou as escondidas, minha avó prometeu me casar com Jorge. Aquele rapaz com ar de bom moço que se tornou pelas mãos do destino o amante da minha mãe e o assassino do meu pai. Entra áudio de Ofélia, vai até atrás do varal, põe a venda, pega a vara que está apoiada na parede e coloca, uma a uma as bonecas: 1, 2, 3, 4, 5.

15 “(...) es preciso imaginar el monólogo interno. No se há de sufrir com la Idea de que es necesario componer todos estos monólogos. (...) se necesita que estos pensamientos se vuelvan cercanos y queridos para el intérprete" (idem, p. 108). 


\begin{abstract}
"Como tem passado vossa alteza nos últimos dias? Meu senhor guardava de voz umas lembranças, que a muito desejava devolver-vos. Rogo que aceitais agora. Meu respeitável senhor. Sabeis muito bem que sim. E com frases de tão doce alento, que muito mais preciosas se tornaram. Perdido o perfume, recebei-as de volta... Senhor?" Voz: "A cada uma que encaixo, a pontuação do barulho do encaixe: "Consegui, olha aqui, tudo bem” Mas, quando tento encaixar várias vezes a sexta sem sucesso, surge: 'Rá! Rá! Eu te pego guria! Rá!'”. Rá! Rá! Eu te pego guria! Rá! Rá! Eu te pego!! (Arrasta-se na parede) Pai nosso que estás no céu santificado seja! Não convém nenhum tipo de amizade com esse tio Aristeu. É rico! Sim, rico! Mas bandido! (Chega ao quadro-negro). Santa Maria mãe de Deus rogai por nós! Nunca vi alguém tão parecido com o demônio! (Encontra um giz). Santo anjo do senhor meu zeloso guardador! Cria moças e bate nelas com o chicote! Uma vez lanhou o rosto de uma. A pobrezinha ficou tão escabrunhada que enlouqueceu! Mas "pior que a loucura é a vergonha" (Completa a frase "Pior que a loucura é a vergonha”). Aliás, você não devia chamá-lo de "tio" Suzana! Nem irmão legítimo do seu pai ele é! VOZ: Suzana ardendo! (Meu deus, Suzana ardendo! Caminha às cegas para a caminha) Suzana! Suzana! VOZ: Em uma espécie de juramente íntimo. Uma moça que perde pai e mãe já está em idade de se casar. E Jorge é bom. Meigo. Se houve alguma coisa entre minha filha e ele foi uma fatalidade. Foi por causa do temperamento dela! (Procura. As mãos tremem) Tem mulher que só tem sossego na morte! Nem o casamento, nem o marido, nada adianta! VOZ: Toco. Tateio. O rosto. A testa. Toco. Tateio. O lençol. Seguro. A boneca. Puxo. Abro. A mão-pássaro. Perto do rosto. (Abre o paninho manchado de vermelho perto do rosto. Cheira e sorri. Agora sim, a surpresa do cheiro!) Apoiada na parede se deixa escorregar. Praguejando baixinho): É um demônio, um demônio; é um demônio, um demônio. VOZ: "A avó faz uma dança em rodopios - riso, variação de tonalidades da voz, agudo, um prazer orgiástico junto à necessidade de preenchimento do espaço com a voz e a teatralização do corpo. "Bruxa"; "anciã feiticeira”, risadas, gritinhos, granhidos, exacerbações, palavras sublinhadas com ênfase”. (A cena é invadida pelo silêncio. Ela tira a venda. Humildemente olha a cena e coloca a vara de bonecas no varal. Tempo).
\end{abstract}

Durante a memorização do pré-jogo, acontecem associações atravessadas. Uma propriedade de refração do significante é testemunhada: a passagem por um significante gera associações diferentes a cada vez que se repete a escrita do texto. As associações no eixo vertical são fragmentadas e implicam uma plástica (imagens e vozes) da própria vida. Algumas falas ganham ênfase: "E bate nelas com o chicote"; "As mãos pássaros" - enquanto outras seguem o fluxo normal. Isto implica dinâmica. $\mathrm{O}$ ato de repetir os nomes dos materiais que incidem no ator implica um envolvimento (na imobilidade) do corpo inteiro. Como acontece com a partitura musical, o corpo inteiro do pianista vibra quando ele está parado, sentado no banco, tocando. Os momentos de pausa são cheios de incidência; há momentos "fortes" e outros "pianíssimos" (avesso de forte, quer dizer "fraquíssimo"). Estes momentos entram em contraste, criando ritmo, movimento, dança. 


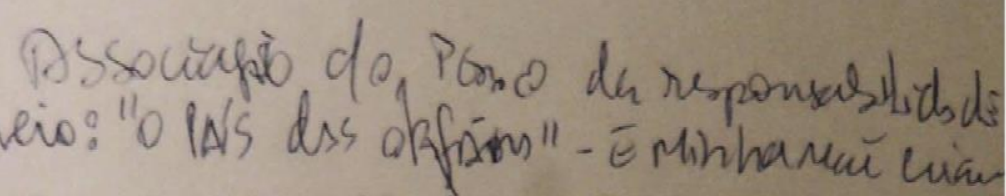

VOZ: Há alguns anos atrás, no leito de morte daquele que amou 'as escondidas, minha avó prometeu que zelaria pela felicidade de seu filkon aquele rapaz com ar de bom moço que se tornou pelas mãos do destino o

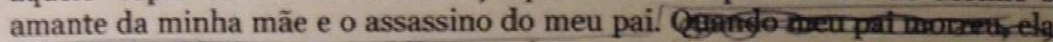

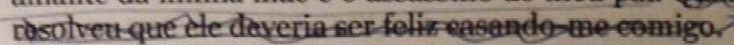

Ao lado das bonecas está a saia da avó. Ela tira a saia do varal, veste. Segue a descrição da voz em off para encarnar a avó.

VOZ: Minha avó era uma mulher antiga e nervosa. Visivelmente cansada. As mãos carregadas de gestos. Os pés amarrados codicionavam o tamanho dos seus passinhos. A boca curvada para baixo em uma espécie de esgar de nojo. As pálpebras caídas. As cochas duras apesar de velha e ágil apesar de cega.

Põe a venda. Um fio de luz sobre o rádio que se encontra no procênio. Entra gravação do diálogo da cena de Ofélia devolvendo os presentes a Hamlet (sonoridade de radio-novela). Arrastando-se pela parede, ela chega ao quadro-negro. Encontra um giz e completa a última frase: "(Pior que a loucura) é a vergonha". Pega a vara que está escondida no quadro-negro. Coloca sobre as costas, uma a uma, as bonecas: $1,2,3,4,5,6$. Caminha d̀s

cegas para perto da caminha de boneca que está suspensa; seis passos enquanto pragueja.

AVÓ: Não convém nenhum tipo de amizade com esse tio Aristey-Pai-nosso que estás no céu santificado seja! É rico! Sim, rico! Mas bandido( Santa Maria) mãe de Deus rogai por nós!/Nunca vi alguém tão parecido com o-demồní! Pecadores agora'na hora de nossa mortel/Cria moças e bate nelas com o chicote! Santo anjo do senhor me lanhou o rosto de uma. Nossa senhora mãe de Deus! A pobrezinha ficou tão escabrunhada que enlouqueceu/Pai nosso que estás no céu! Mas pior que a loucura é a vergonha! (Baixa o tom)/Aliás, vocế ñão devia chamá-lo de "tio" Siram! Nem irmão legitimo do seu pai Simples irmão de criação. (Meu deus! Suzana ardendo! Caminha mais um pouco em direção 'a caminha. Procura a cama, as mãos tremem. Em uma espécie de juramente intimo): Juma moça que perde pai e mãe já está em condições de casar. E Jorge é bom. Meigo. Se houve alguma coisa entre minha filha e ele por causa do temperamento dela! Bendito é o fruto do vosso ventre! Tem mulher que só tem sossego na morte! Nem o casamento, nem o marido, nada, adianta! (Baxxo) Toco. Tateio. O rosto. A testa.

boneca. Puxo,Ábro. Á mão-pássaro-Perto do rosto./Tenho a surpresa do cheiro. (Cheira o paninho manchado de vermelho e sorri) Agora sim. A surpresa! (Apoiada na parede se deixa escorregar. Encostada na parede praguejando... baixinho, repetindo) É um demônio, um demônio; é um demônio, um demônio.

Figura 107: O Pré-jogo da "Cena 2: Os Cuidados da Avó" 


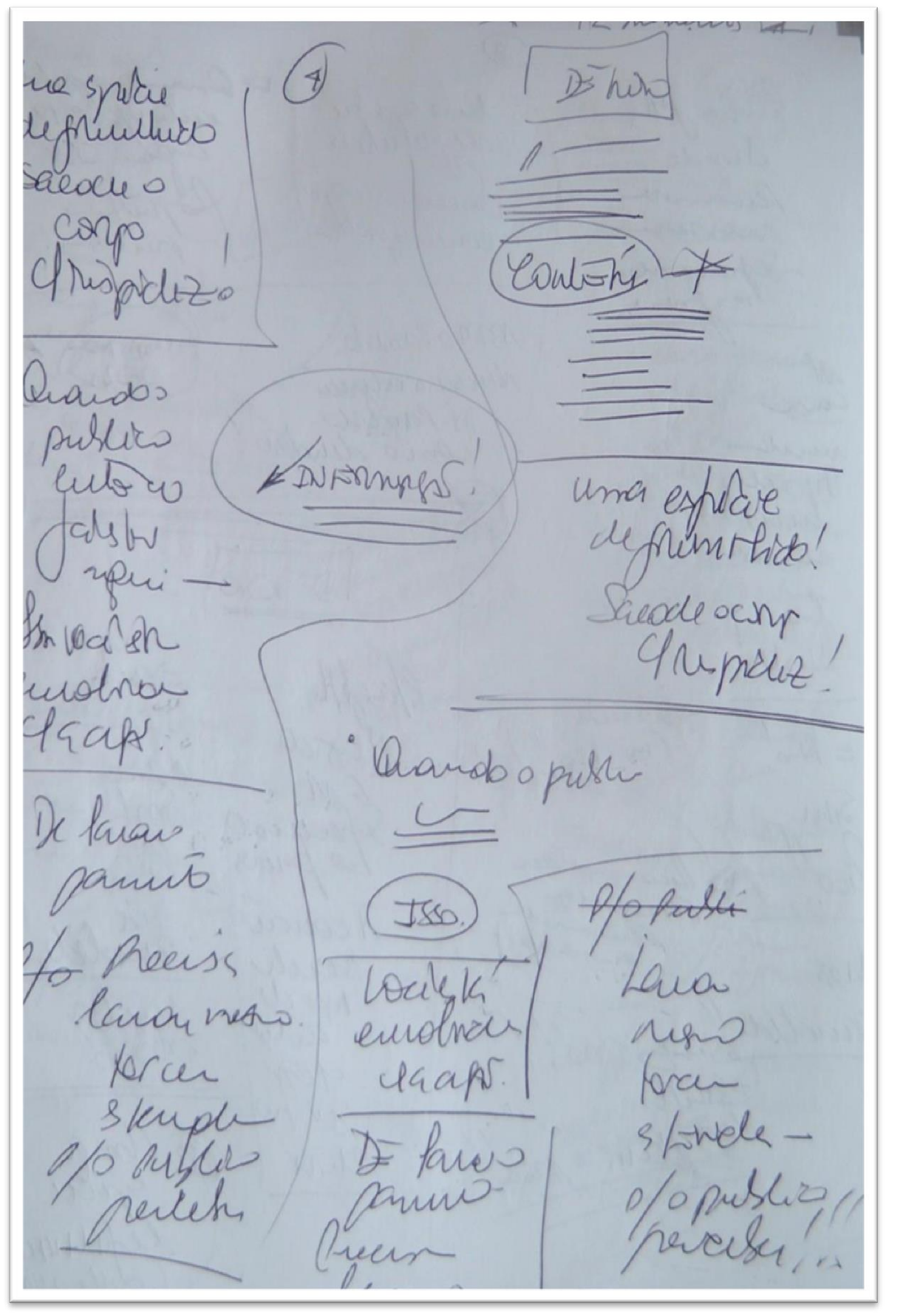

Figura 108: Pré-jogo sendo memorizado.

158 


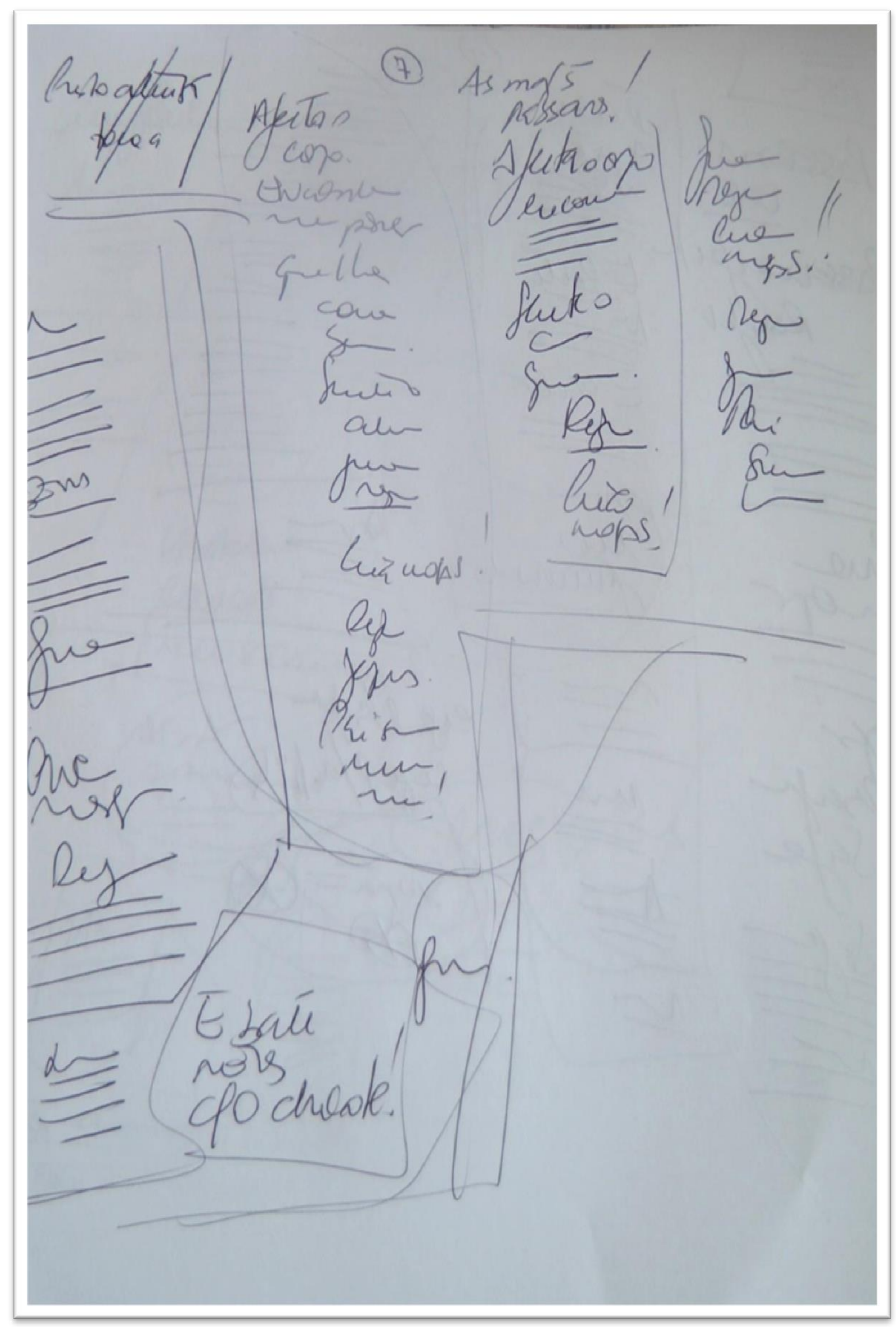

Figura 109: Pré-jogo borrado 


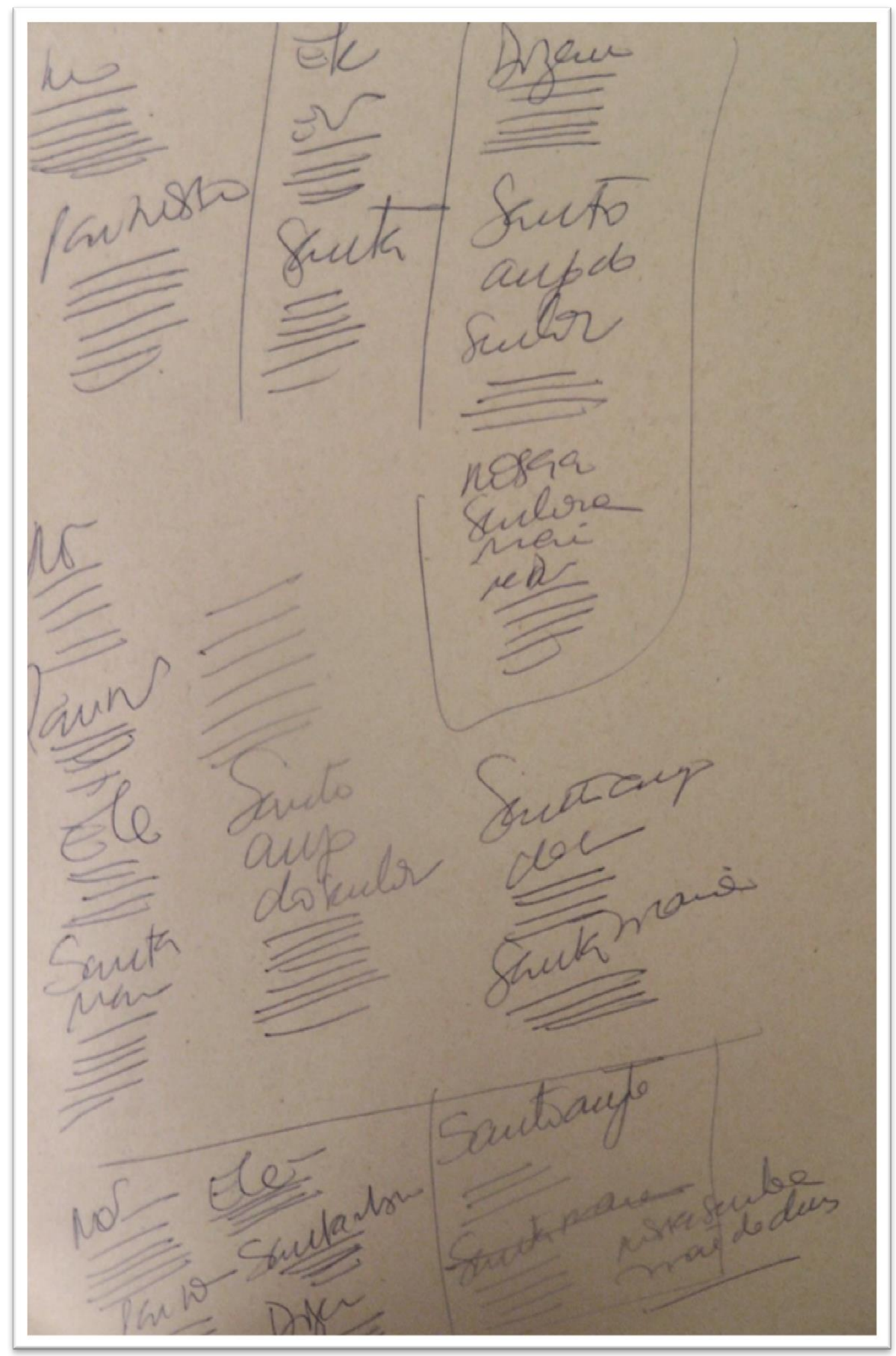

Figura 110: Pré-jogo na etapa da "psicografia" 
No final temos acúmulo, um excesso de reverberações que, em cena, precipitase. A impressão digital aparece como precipitado, resíduo (enquadrado de alguma maneira). Em cena, estão enquadres sonoros fixos - que não dependem da vida do corpo para serem atualizados: são mecânicos, gravados (como a régua sonora e a música). Na régua sonora, coloco frases de Ofélia devolvendo presentes a Hamlet, associando a plasticidade da voz à música habitual da rádio novela. As falas de Ofélia fazem alusão à mulher desenganada, enquanto a fala da avó evoca uma plástica ficcional: "Se houve alguma coisa entre Jorge e minha filha, foi culpa do temperamento dela. Tem mulheres que só encontram sossego na morte. Nem casamento, marido, nada adianta!’. O imaginário, a interpretação, está em jogo: a garota vê uma oportunidade para vingar-se da morte dos pais. Faz incidência. Não situa o foco, no entanto. O que situa o foco é a instrução de jogo.

Entre uma Apresentação e Outra:

Entre uma apresentação e outra desta cena levou meses. A tentação de muda-la foi grande. Quando trabalhamos a Memorização Através da Escrita para um texto dramático, há enquadramento fixo da fala externa já definida (o texto do autor). No ateliê de "Casa" havia a liberdade de criar inclusive a fala. O risco de me deixar levar por novas incidências e mudar tudo era enorme. Criei um pré-jogo totalmente diferente e cheguei a memorizá-lo. Apareceram associações com o corpo de um homem (presente no espaço, ocupando-o quase inteiro). A incidência desta imagem me permitia (apoiava) percorrer o espaço (explorar o espaço enquanto visualizava o corpo do homem, quase o tocando). Vinham associações com o prazer no contato com o corpo - como se ele estivesse ali, diante dos olhos "da avó". Chequei a escrever uma fala interna: "O ar é o corpo que percorro". Ensaio um pouco com este material: "O ar é o corpo que percorro" sustenta o foco, enquanto desenho as ações da avó. Mas decido manter a forma original do arranjo. Aquele segundo pré-jogo foi como um desvio; algo que memorizei e deixei de fora (o que quer dizer que há novo material para entrar na área de vulnerabilidade, sem querer, se for articulado).

No ônibus, indo para a USP, vêm novas associações com o corpo masculino que, agora, passado para a ficção, é o corpo do amante da avó no passado (enquadrei na ficção). Esta era a imagem interna para a fala: "há mulheres que só encontram sossego 
na morte, nem o marido, nem o casamento, nada adianta”. O desvio pode ser colocado em outro lugar da subpartitura. Mas esqueço. Memorizo até a exaustão falas e rezas: materiais poderosos porque, em cena, há o manejo das bonecas, a escrita no quadronegro, o percurso no espaço com os olhos vendados. E estas falas e me ajudam a preencher o tempo de realização das ações. Elas são materiais auxiliares para o improviso e me ajudam a dar enquadramento às impressões digitais. A malha sonora preenche o espaço. A voz é descolada do corpo na medida em que amplificada mecanicamente. Ela situa parte do foco e faz incidência com a sua dinâmica. Uso a voz no microfone, passo para a voz gravada, entra a música: uso vários sons. O foco se desloca pelas diferentes plasticidades sonoras, enquanto se divide com a imagem acústica (oculta) da instrução. A voz sonorizada vem de fora, mas é uma espécie de figuração da voz "oculta”: escuta dos significantes, íntima e estranha ao mesmo tempo e que, neste caso, se consolida como voz.

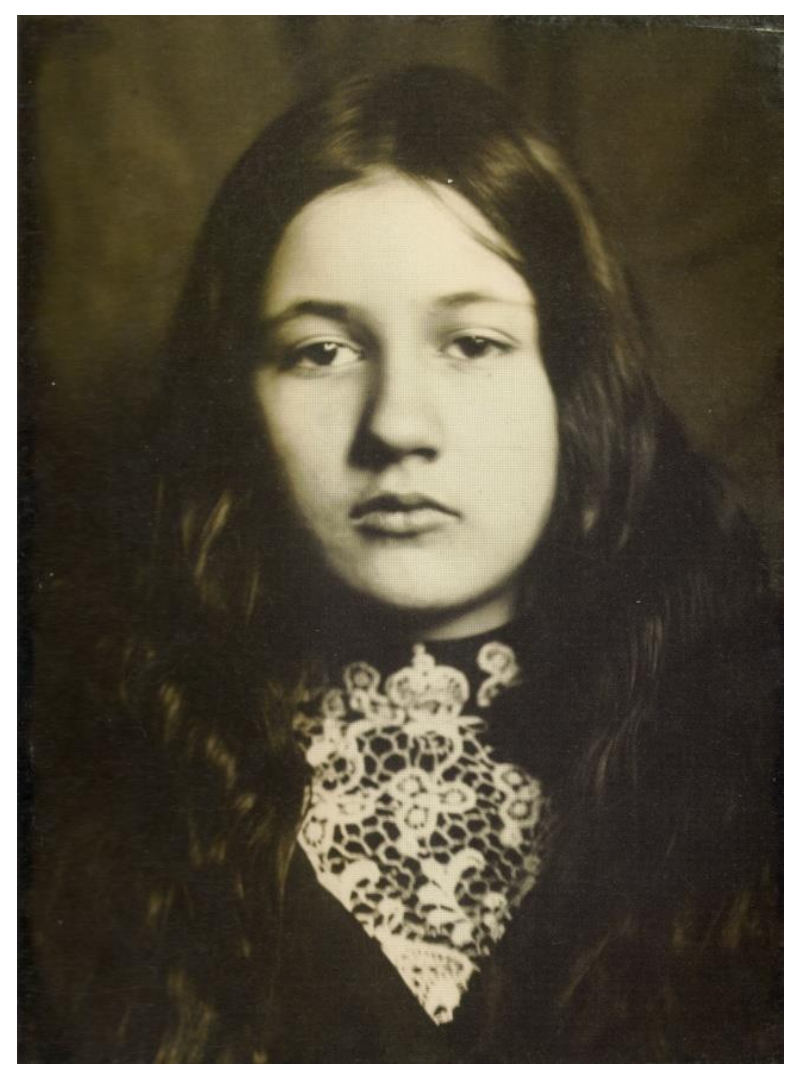

Figura 111:

Fotografia projetada na cena "Os

Cuidados da Avó"

No espaço, me deparo com a minha sombra junto à foto da menina (projetada) e resolvo utiliza-la. Aparece um tom de narrativa fantástica, junto a certa sonoridade vocal criada anteriormente (durante a memorização da "Cena 1: A Morte dos Pais") e 
que retorna. A voz da escritora: como a voz de minha avó contando histórias quando éramos pequenos. Quando saio do lugar (e a sombra se desmancha na parede), a sonoridade da última frase associa um tom maniqueísta: "Assassino do meu pai" adquire um tom acusativo, lembrando-me (em um instante de associação repentina) da sonoridade de um espetáculo do qual eu havia participado em 1992. É possível observar uma rede, que se atualiza na medida em que algo faz incidência e reverbera (aparece na cena do corpo). Mesmo com materiais fixos, a cena segue no espírito do improviso. A voz sai do corpo, expelida, para preencher o espaço (e oferecer o enquadramento), a partir de uma regra de preenchimento do espaço (que está em foco). Aparecem gritos: “Suzana! Suzana!”. "Preencher o espaço com a voz” é a fala interna. E em seguida: "Preciso chegar até a caminha".

Antes da apresentação no CEPECA, me vem uma frase que funciona como superobjetivo - e me deixa calma. Uma frase onde eu posso apoiar o foco: "Um país de órfãos". Uma nomeação. É durante nova repetição do pré-jogo que me vem o sentido da responsabilidade da avó de criar aquelas meninas. A avó com uma penca de "gurias" (termo que usamos no Sul), tendo que preveni-las contra Aristeu (um homem cruel que se aproxima com "poses de tio"). Este enquadre ficcional, articulado ao superobjetivo "um país de órfãos" altera a atmosfera da cena. Eu falava de orfandade. Inclusive, cito Jorge (o ex-amante da mãe): também órfão. Lembro-me da minha mãe, que ainda menina perdeu o pai e foi morar com a avó. Quando a sua mãe casou-se novamente, ela se foi. Minha mãe era uma órfã. "Um país de órfãos" é a frase que situa a cena; a porta de entrada. Acontecesse o que acontecesse (e eu iria improvisar com estes materiais) tudo iria dar certo, porque a ideia central estava ali: "um país de órfãos" - articulando as coisas. Tal como acontece com o superobjetivo stanislavskiano: um material situa o foco e outros se precipitam na área de vulnerabilidade.

No novo improviso no CEPECA vêm novos materiais. Eu rio, rodopio, vario as tonalidades de voz, vou para o agudo às vezes. Começa com "Rá, rá, eu te pego guria, eu te pego!". Quando não consigo colocar uma das bonecas na vara, preencho o tempo com isto: "Rá, rá eu te pego guria, eu te pego" (enquanto, vendada, tento encontrar a boneca). Este "Rá!!!” também aparece quando a avó descobre o sangue no paninho de Suzana. Nomeio este momento: "prazer orgiástico junto à necessidade de preenchimento do espaço com a voz e a teatralização do corpo" - e coloco a nomeação na régua sonora. Eu tenho em jogo "bruxa", "anciã" e "feiticeira". A tessitura corporal atualiza materiais: "risadas, gritinhos, exacerbações, exageros, palavras sublinhadas 
com ênfase". Novamente, a nomeação vai para a régua sonora: "risadas, gritinhos, exacerbações, palavras sublinhadas com ênfase". Aparecem impressões digitais vocais, criadas em tempos passados: em treinamento vocal com o Antunes Filho em $1993^{16}$-e atualizadas agora. Algo que as enlaça no passado é atualizado, em cena, quando menos se espera. A escuta do corpo vai entrando em jogo. Se me surpreendo com a potência que a primeira fala adquire, esta surpresa entra em jogo com a segunda fala. Coloco as bonecas na vara, contando: "1, 2, 3, 4, 5" deram certo! "A cada uma que encaixa a pontuação do barulho". É como se, internamente, eu dissesse: "consegui cumprir a instrução de jogo, olha aqui, está tudo bem" (esta era a ação interna, um pensamento em nome próprio). Coloco esta descrição na régua sonora: “A cada uma que encaixa a pontuação do barulho".

Há materiais fixos, mas o improviso se mantém. Os materiais entram com o pacto, com a regra do jogo, que não elimina, mas muito pelo contrário, é condição para que um improviso se estabeleça. Há materiais objetivados em cena: enquadramentos externos que não dependem da atualização no corpo: varal; projeção; bonecas; quadronegro. Há materiais cravados no corpo vivo: movimentos; a voz, que despenca pra fora (fala externa e rezas dependem da atualização no corpo). Depois de comemorar a menstruação da menina, com a tal dança em rodopios, tiro a venda e fico olhando para o que tinha acabado de viver, embasbacada. Olho os objetos e rememoro. Ainda em cena, corro para procurar papel e caneta. Ponho-me a escrever, agachada. A lógica da encenação se estabelece naquele momento - articulando um material (a voz de Silva): “Além de escrever para viver você pode viver para escrever". A ação "viver para escrever" aparece no improviso, fora do foco, junto à incidência de um material (uma voz) instalado no texto do processo.

As associações "pipocam” quando dialogo no CEPECA. Abrem-se compotas. Lembrando o que foi cenicamente configurado (utilizando a cena como um campo de extração), instalo um material novo, "engordando" o arranjo. Por exemplo, na projeção está a imagem de uma mulher estapeando um homem. Em cena, estou com um buquê nas mãos sem saber o que fazer. Uma associação vem durante uma ação cotidiana, como atravessar a rua (muitas vezes é quando estamos distraídos que as associações acontecem). A plasticidade da cena que tenho diante dos olhos (função do olhar) se encontra com a ficção: "ela está com medo" penso. São duas visualidades que se

\footnotetext{
${ }^{16}$ Estive no "Centro de Pesquisas Teatrais", coordenado por Antunes Filho em São Paulo, nos anos de 1993 e 1994. Dedicávamo-nos a uma pesquisa de lugares do corpo para fazer ressonar o som e apresentávamos performances com a voz. Os olhos mantinham-se fechados.
} 
enlaçam através de um significante, fazendo incidência naquele instante: "medo". Encontro lugar para ele no enquadramento cênico para encenar a sua incidência. No entanto, se não sustento este lugar, se não o fixo (em uma escrita), a incidência passa (e não uso este encontro). Alguns encontros são como os das pessoas que se esbarram, mas não se enlaçam. Para enlaçar-se é preciso escrever, seja no papel (texto dramático) ou na cena: escritura cênica.

Mas vamos supor que a associação não tivesse "vindo" (porque as associações não "vêm" o todo tempo); enquanto o encontro de um material incidente com a imagem da cena não vem, esta incidência fica sem lugar para ser encenada (ou seja, fica sem enquadramento cênico). Mas posso pegar a cena do Nelson Rodrigues, memorizar e deixar fixada em mim. Em um instante, no ato cênico, com o corpo no enquadramento cênico espaço-temporal, eu percebo uma brecha, um tempo a mais e aquela incidência "pula", se instala na impressão digital, com uma associação, a um só tempo. Porque estou em cena. Ali o corpo reage cenicamente quando a associação aparece (encena a incidência), pois estou sob a incidência do olhar do outro (que espera algo de mim). É para o olhar do outro que enceno. E, também, porque tenho materiais para entrar nesta área de vulnerabilidade (já que experiências me marcaram). Então, é possível que o encontro (uma associação com a qual uma incidência ganha lugar) venha no pré-jogo (antes); venha durante o cotidiano (em momento de distração); durante um diálogo (em interlocução); que venha durante o exercício de estar em cena. 


\section{TECIDO}

E isto, o sentido ou o sem-sentido, é algo que tem a ver com as palavras (Jorge Larrosa Bondía)

\subsection{Um Passo a Passo para a Fundamentação do Procedimento}

\subsubsection{Duas Cadeias: Spolin no Ateliê}

Como instrutora de jogo, Spolin oferece a sua voz: "fisicalizar a imagem de uma bola" é a sua instrução (uma bola que não está, como objeto, inscrita na realidade objetiva). Na "Oficina da Essência", o ator rememora uma figura de Klimt, Munch ou Modigliane para provocar o corpo. Em Spolin, não se trata de uma imagem extraída das artes plásticas, mas a bola encontra-se rememorada. Ao interseccionar Silva e Spolin se encontra o seguinte: a imagem da bola é um anteparo e fisicalizar é criar uma impressão digital (que sofre a incidência da imagem e também da voz de instrução). Utilizar a hipótese do anteparo como estrutural é ler a teoria descobrindo as relações anteparoimpressão digital. Trata-se de fazer com que uma visualização incida sobre o corpo, constituindo uma impressão digital. No entanto, o que se percebe em Spolin? São necessários anteparos acústicos auxiliares.

Stanislavski problematiza o caráter evanescente (e escorregadio) da imagem. Segundo ele, o ator deve treinar a capacidade de criar e sustentar internamente imagens, diariamente. Esta necessidade de treino testemunha que a imagem (oculta, que não está inscrita na realidade objetiva) não é um anteparo que se sustenta tão facilmente no foco. Já a imagem acústica (basta cantarolar uma música em silêncio e repeti-la) parece ser fácil de atualizar e permanecer, ao ponto de, muitas vezes, importunar (de invadir-nos de maneira indesejada), de fazer uma incidência despropositada.

Em Stanislavski, o ator escreve trechos da vida da personagem, circunstâncias dadas que inventa (ou "detalhes imaginativos"). Assim, ele treina a visualização interna enquanto ouve a imagem acústica das palavras, que se desdobram nas cadeias escritas e o "levam". Da mesma maneira, no ateliê, apesar de não poder se mexer, de não sair do lugar (apesar do enquadramento, naquele momento, estar limitado ao "sentar-se e 
escrever"), o ator sente o fluxo de um deixar-se levar. A incidência das cadeias se fortalece na medida em que o enquadramento está limitado. Por fazer oposição às ações (implicadas nas cadeias), a imobilidade fortalece a sua incidência. Testemunha-se a estrutura. Agora, com suas casas ocupadas com as modalidades de materiais específicas deste procedimento.

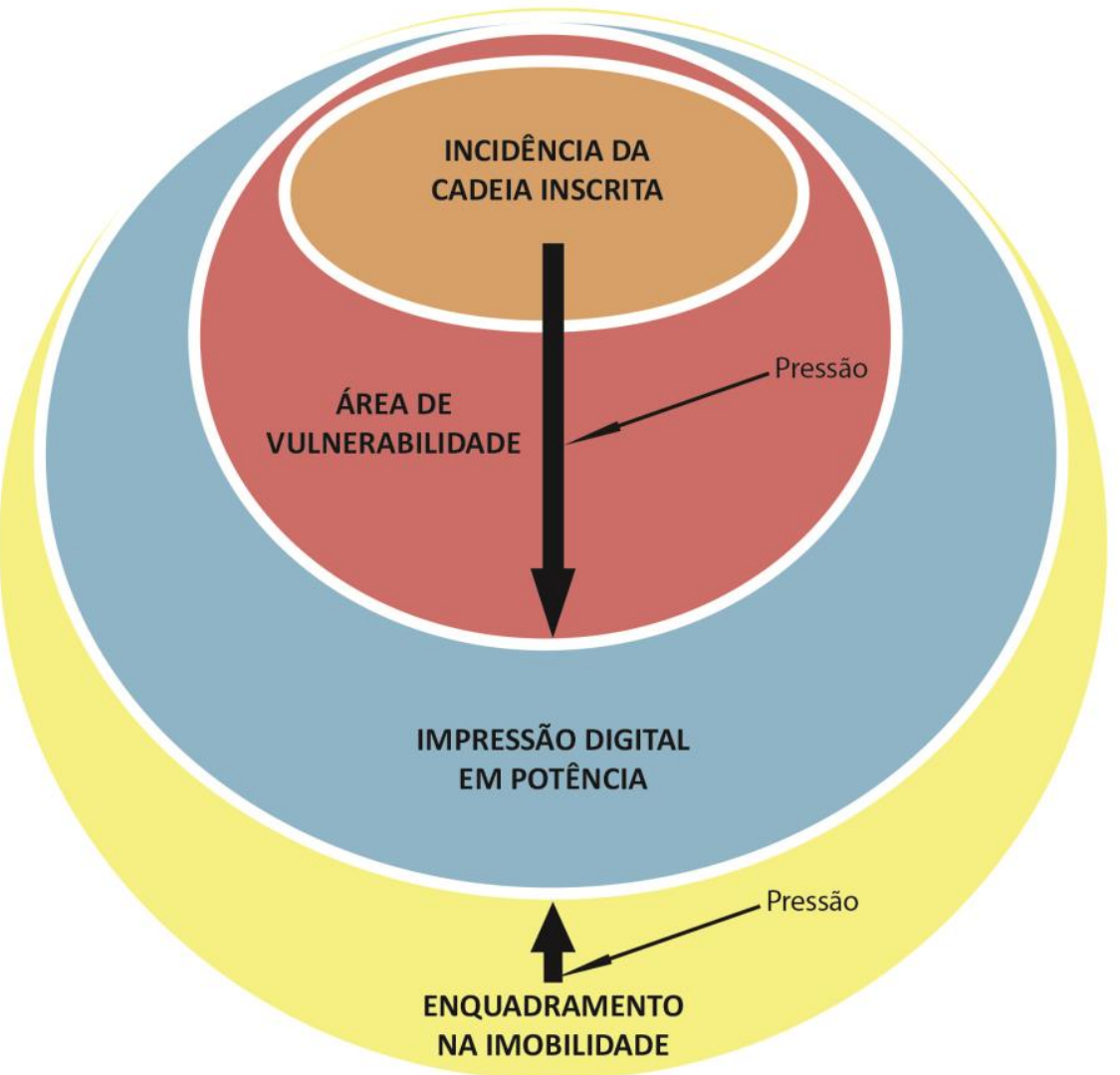

Figura 112: Incidência, Enquadramento e Vulnerabilidade na M.A.E.

Durante a escrita, as visualizações transpassam o ator. Uma boa metáfora é: quando percorremos de carro uma autoestrada, os outdoors, as paisagens, passam, vão aparecendo e desaparecendo, se substituindo como em um tubo mágico. Durante a escrita as imagens passam; não se controla este fluxo de revezamentos, de sutis e súbitas associações e da vivência que estas implicam no corpo porque o atravessam. Imagens acústicas se articulam às visuais neste tempo sem enquadramento que Stanislavski chama "fração infinestezimal” (de supetão e cujo efeito de incidência já está no corpo). Outra metáfora seria este tempo que Clarice Lispector chama de "átimo". 
Não compreendo o que vi. E nem mesmo sei se vi, já que meus olhos terminaram não se diferenciando da coisa vista. Só por um inesperado tremor de linhas, só por uma anomalia na continuidade ininterrupta de minha civilização, é que por um átimo experimentei a vivificadora morte. A fina morte que me fez manusear o proibido tecido da vida (LISPECTOR, 1998, p. 15).

"Ela narra esse acontecimento que se dá na temporalidade do instante de ver" (DEL NERO, 2011, p. 236). É este tempo de instantaneidade que estou articulando como o tempo da incidência. "Tempo de precipitação", que Jacque-Alan Miller (1997) diz ser diferente do cronológico. Tempo de pulsão, onde não se tem garantias, pois não se tem o antes. Tempo do ato: quando se vê, já aconteceu. Quanto o escritor percebe, ele já foi invadido pelo excesso, olhar texturizado com o gozo. No "Ateliê do Ator-encenador" o procedimento para a criação de imagens (acústicas e visuais) internas é este: escrever.

Com os meus alunos, nomeei esta etapa (da escrita) de "psicografia" - uma etapa que não está no procedimento de Khan ${ }^{1}$. O procedimento "Memorização Através da Escrita" original é difundido por François Khan, ator do Teatro Pontedera (ligado ao Teatr Laboratorium, coordenado por Thomas Richards) e que participou do Teatro das Fontes com Grotowski; hoje diretor do Teatro de Câmera. Em 1997 entrei em contato com o seu procedimento graças à criação, na USP, junto à estudante de direção Glaucia Felipe, de um espetáculo com trechos de Clarice Lispector (que resultou no espetáculo "Quatro Vestidos Vestem Clarice”). Foi Glaucia Felipe quem transmitiu às atrizes a Memorização Através da Escrita, formalizada por Khan - com quem ela havia estudado. Depois de repetir a escrita de uma fala externa até a memorização, esta fala aparece, em cena, no lugar do espontâneo, enquanto o foco se situa em outro material (determinado ritmo, por exemplo). Uma sucessão de incidências fixada pela repetição da escrita é combinada com anteparos que ordenam o espaço-tempo (enquadram). O movimento, o ritmo entra em jogo (ou em tensão) com a cadeia da fala. Desta relação, surgem as impressões digitais, como resultantes (sempre frescas) de um jogo com mais de uma incidência. É a maneira como, hoje, descrevo o procedimento, valendo-me dos termos elaborados no "Ateliê do ator-encenador".

No final da minha pesquisa de mestrado junto a "Quarttet", de Heiner Müller, propus fazer o mesmo com uma sucessão de interjeições (como "Idiota" e "Sai daqui") - um texto interno que marcou, junto ao texto falado em cena, lugares onde, na área de

${ }^{1}$ Ver em KHAN, F. Reflexões sobre a prática da memória no ofício do ator de teatro. São Paulo: ECA-USP: Revista Sala Preta, no. 9, pg 147-157. 
vulnerabilidade reapareceram ações físicas (já constituídas durante o processo e que evocavam a imagem de uma ação para as falas, fazendo aparecer uma plasticidade da relação com o homem) que até então não tinha aparecido (não tinha sido vista na leitura do texto de Müller). A fala interna era uma demanda direcionada a alguém. Por implicar incidência, articulava a atriz com a ficção, a invenção "personagem”. Porque preenchia de incidência o enquadramento da fala e, ao atualizar a plasticidade corporal construída no processo, evocava as ações. O arranjo contava com duas instruções de jogo, que se revezavam: "fazer gestos grandes" e "ocupar todo o espaço". Estas duas regras se revezaram no foco, enquanto os ecos das incidências das falas internas e externas foram introduzidos fora do foco. Era uma montagem que se dava em jogo, na medida em que uma fala interna articulava, durante o improviso, uma ação física (que reaparecia porque estava na memória corporal). Esta ação física reaparecia para preencher tempo e espaço cênico, para organizar os efeitos de incidência no tempo e espaço cênico (já que seu enquadramento evocava a ideia de ação veiculada na fala, que se descobria naquele instante). A descoberta desta modalidade de jogo (com uma cadeia de falas internas e externas intercaladas) representou um ponto de virada na minha vida de atriz, pedagoga e pesquisadora. Já na pesquisa de doutorado comecei a testar um segundo deslocamento da Memorização Através da Escrita: também a memorização das descrições de corpo em função do jogo de enquadramentos (articulação com os anteparos de Silva).

Quando está bem memorizada, a cadeia do pré-jogo flui em uma velocidade mais rápida do que a mão que escreve, borrando os movimentos e a grafia do texto. Não se entende a caligrafia, que se parece com a escrita psicografada (por isto apelidamos esta etapa de psicografia). Em cena, o ator pode usar as falsas internas que criou com a escrita ou outras, de maneira que aquelas fixadas no pré-jogo serviram apenas para criar fissuras (que serão preenchidas por novas falas internas).

Spolin testemunha o funcionamento da cadeia de imagens acústicas: "Deixe seu corpo mostrar a vida do objeto! Mostre com os pés! Com os ombros! O cotovelo!" (SPOLIN, 2010, p. A41) - fazendo incidência no corpo durante a cena. Mas o próprio ator pode criar a sua "descrição de corpo" - ou a sua cadeia de imagens acústicas - de maneira a se autodirigir, se autoprovocar com anteparos (Silva, 2009), libertando-se do outro (do instrutor de jogo ou diretor) ou fazendo parceria (não dependente deste outro). Nos jogos teatrais de Viola Spolin, existem cadeias de imagens acústicas em arranjo com imagens visuais (do próprio corpo) para a criação de uma sequencia de impressões digitais que implica afeto. O que entra no arranjo não são as circunstâncias imaginárias, 
mas a imagem do próprio corpo: uma modalidade de cadeia acústica. No seu fichário ${ }^{2}$, Spolin situa jogos teatrais onde a voz de instrução está presente: o jogador tem estas imagens acústicas fazendo recortando e descrevendo o seu corpo o tempo todo.

\begin{abstract}
Sinta os pés nas meias! Sinta as meias nos pés! Sinta os pés nos sapatos! Sinta os sapatos nos pés! Sinta as meias nas pernas! Sinta as pernas nas meias! Sinta a calça ou saia nas pernas! Sinta as pernas nas calças! Sinta a roupa de baixo perto do seu corpo! Sinta o corpo perto da roupa de baixo! Sinta a blusa ou camisa com seu peito e sinta o seu peito dentro da blusa ou camisa! Sinta o anel no dedo! Sinta o dedo no anel! Sinta o cabelo na cabeça e as sombrancelhas na testa! Sinta a língua na boca! Si ta as orelhas! Vá para dentro e tente sentir o que está dentro da cabeça com a cabeça!Sinta o espaço à sua volta! Agora deixe que o espaço sinta você! (idem, p. A2)
\end{abstract}

O foco desliza, dividido com as impressões digitais, inscritas em sucessão. $\mathrm{O}$ problema "fisicalizar a bola" é resolvido quando o ator se deixa levar pela incidência da voz que o ajuda a construir o corpo. Da mesma maneira, no "Ateliê do Ator-encenador", durante "o deixa-se levar pela voz que se escuta" (enquanto a grafia faz oposição ao fluxo contínuo das imagens), potencializando o afeto no corpo, revive-se, apesar da imobilidade (se treina) esta cadeia. Tal como o "Treino na Imobilidade" de Grotowski: há a rememoração e repetição (interna) da imagem do corpo.

\begin{abstract}
Sem que os outros percebam, se pode treinar as ações físicas, e fazer as composições das ações físicas permanecendo no nível dos impulsos. Isso que dizer que as ações ainda não aparecem, mas estão no corpo, porque são $\mathrm{im} /$ pulso. Por exemplo: em um momento de meu personagem estou em um jardim sentado em um banco, alguém se senta ao meu lado, eu o olho. Agora trabalho sobre este momento sozinho. Exteriormente - não estou olhando esta pessoa - faço somente o ponto de partida, o impulso de olha- lo. Do mesmo modo executo o impulso de inclinar-me, de tocar a sua mão (o que Grotowski faz é quase imperceptível), mas não o faço parecer plenamente uma ação (...). Mas, não a exteriorizo. Agora caminho, caminho,... mas permaneço na minha cadeira. É somente assim que se pode treinar as ações físicas. Mas há mais; as vossas ações físicas serão assimiladas ainda mais pela vossa natureza se treinarem os impulsos, não as ações. Podemos dizer que a ação física quase nasceu, mas ainda é bloqueada, e assim, no nosso dizer, estamos "impostando" uma reação justa, assim como se imposta a voz. (RICHARDS, 1993, p. 94 apud BONFITTO, 2007, p. 74)
\end{abstract}

Sem que o ator se mexa (sem que esteja enquadrado no tempo-espaço cênico), ele visualiza. Sente o impulso, mas não organiza, espacialmente, o corpo. Sem que a incidência constitua o desenho, ele a treina, a repete e a fortalece. $\mathrm{O}$ ato da escrita no ateliê também implica a imobilidade. Enquanto escreve, o ator está treinando. Não está repetindo o enquadramento, mas aumentando a incidência para fazer o que está descrito.

${ }^{2}$ VIOLA, S. O Fichário de Viola Spolin. São Paulo: Ed. Perspectiva, 2001. 
Quando vai à cena, deixa a ação tomar o corpo, já que vem de sua memória (dos ecos na área de vulnerabilidade, propositadamente constituídos). Encontrada de maneira geral nos treinamentos, a repetição fixa (passa cola). É preciso bater o prego várias vezes para fixá-lo. Repete-se a escrita para a incidência ser fixada (e seu eco atualizado). Fixada, ela leva o corpo. $\mathrm{O}$ ator pode retirar o foco e brincar de enquadramento. No ateliê, ao entrar, no enquadramento cênico, como aquecimento, temos a regra "experimentar variações". Experimentamos variações do enquadramento plástico corporal na medida em que este sofre a pressão do arranjo - desde materiais intrusivos, que aparecem no momento do improviso. Há sempre arranjo. Então, tiramos proveito disto. E podemos criar duas cadeias, que se arranjam: a descrição de corpo (que implica a ordenação das bordas corporais na poética cênica) e a fala interna (demandada a outro): "Sai daqui!" que implica a plasticidade da relação com o outro (outro tipo de enquadramento). Percebe-se que não se pode escapar de uma estrutura; ela é determinante: jogo de enquadramento, incidência, foco, vulnerabilidade da memória corporal, impressão digital. No ateliê tentamos tirar proveito desta estrutura.

Spolin joga com duas cadeias de instrução ao mesmo tempo. O procedimento testemunha a divisão do foco, com rápidos deslizamentos entre os materiais.

FOCO: Ler e ouvir ao mesmo tempo. DESCRIÇÃO: O leitor começa a ler silenciosamente alguma história ou artigo de um livro ou revista, enquanto o falante relata algum incidente ou experiência passada diretamente para o leitor. O leitor deve colocar o FOCO em estar aberto tanto para o que está lendo como para aquilo que o falante está lhe contando (SPOLIN, 2010, p. A 90).

Em Spolin se encontra jogos para treinar a divisão de foco. Por exemplo, o ator responde a duas pessoas: enquanto uma faz perguntas como "qual o seu nome", "qual o seu telefone", outra pede que realize atividades como "coçar a cabeça", "dar uma volta no próprio eixo". As duas cadeias se revezam no foco, que desliza, rapidamente, de um material a outro, implicando a sucessão de impressões digitais e a instalação de impulso (ou nova incidência) a cada revezamento, a cada troca do foco. Há sucessivas trocas. A cada troca, uma impressão digital. O jogo produz encadeamento de impressões digitais.

Vamos supor que o ator queira repetir a cena. Poderia rememorá-la a partir da repetição do enquadramento (sequência de ações físicas resultantes) ou da repetição do material de incidência: perguntas e instruções. Com as mesmas imagens acústicas, em novo jogo, as impressões digitais seriam outras. É este o princípio do jogo com cadeias 
de imagens acústicas sem que o enquadramento da borda corporal esteja fixado: fixar a subpartitura enquanto a partitura ainda está livre. Para que o enquadramento seja criado no jogo com materiais intrusivos da improvisação. Na fissura entre a incidência destas imagens acústicas e as bordas (do corpo), algo precisa ser constituído.

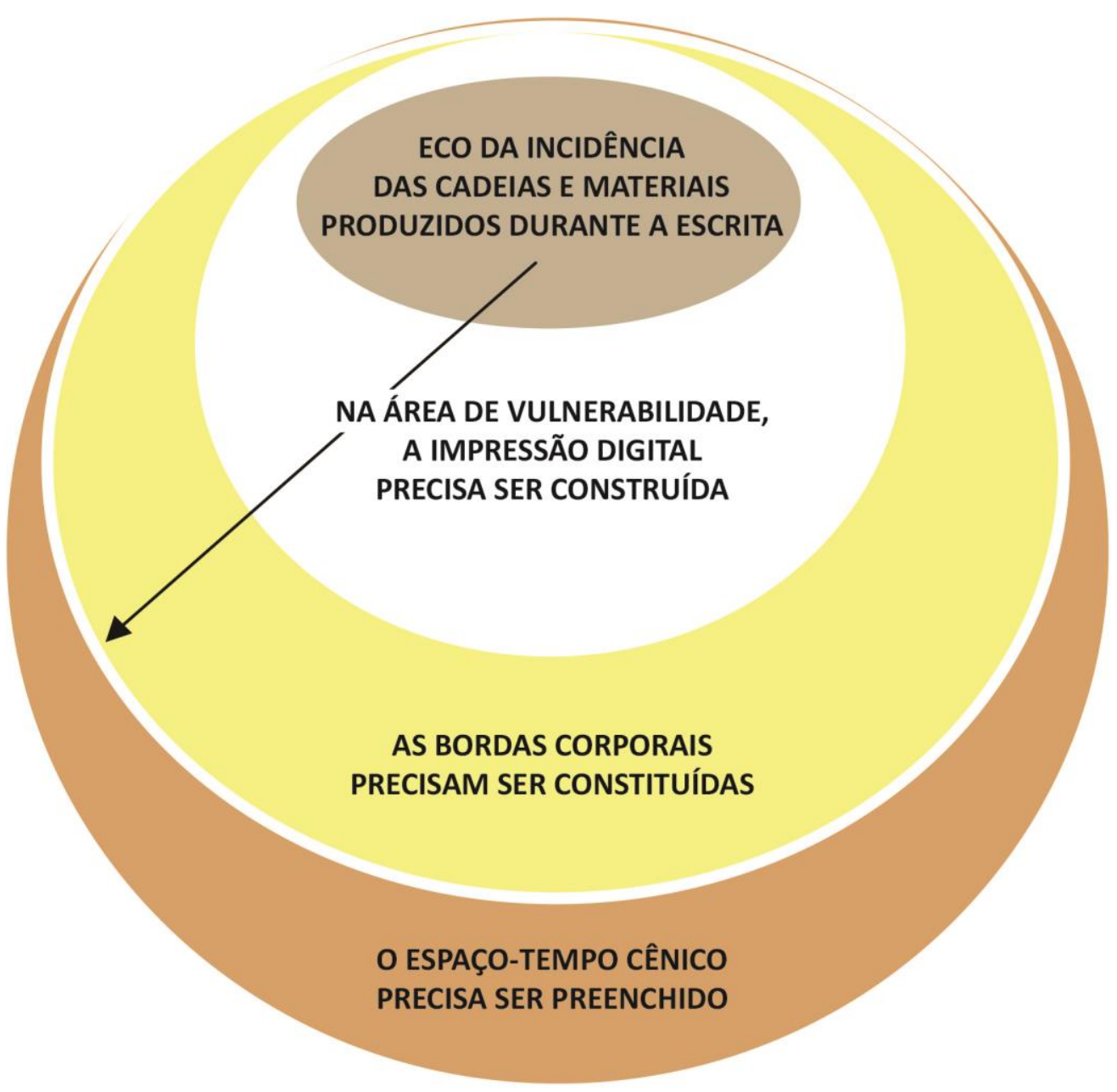

Figura 113: Atravessamentos na Área de Vulnerabilidade

A perspectiva da partitura interna pode parecer estranha à primeira vista, no entanto, é possível. Trata-se do texto de bastidor onde o ator deposita os anteparos: com a nomeação ou a descrição do que lhe queima, lhe faz incidência (seja o que for, pois o importante é causar uma excitabilidade no corpo que pode ser repetida). No entanto, ao entrar em cena e se deparar com o vazio do enquadramento (que ainda não há), é com esta sensação de desamparo que ele cria. Ele ficcionaliza uma sensação que é dele; joga com ela, cria com ela (é material de trabalho). Ele não está protegido ainda. Ele precisa 
construir o enquadramento em improviso. Mas tem todo um detalhamento já impresso que pulsa; reaparece enquanto reverberação; ecos de incidência propositadamente construídos na memória corporal. Deparando-se com o olhar do outro, que queima, o ator atua e cria o enquadramento, que vai desviar este olhar: a sua lua; sua obra.

\subsubsection{Modalidades de Imagem Acústica: Adler e Knebel}

No treino da imobilidade grotowskiano o ator atualiza, "mentalmente" (com a função do olhar), imagens do corpo já enquadrado em cena; uma espécie de narrativa do corpo ou descrição: faço isto, depois aquilo, etc. Uma espécie de rubrica. O que no ateliê se chama "descrição de corpo" é uma modalidade de imagem acústica. Em um procedimento de Knébel, vemos o ator utilizar a descrição, não do corpo, mas do entorno: "Estoy viendo, escuchando, pensando y percibienco tal cosa" (KNÉBEL, 2005, p. 68). Encontramos a escrita no papel para fixar as cadeias do que vê, ouve, pensa e percebe com as mãos. Trata-se de outra modalidade de imagem acústica: o entorno entra em jogo. E também o que ele escuta sem estar na realidade objetiva; que aparece como pensamento (que é como se viesse de fora ou como uma música que lhe invade a escuta). Pensamento como material isolável, que pode ser lido como sendo da personagem: esta é a modalidade stanislavskiana. O trabalho de atuação naturalista no cinema evidencia, também, este tipo de construção. Também as visualizações propostas por Adler. Em Adler vemos uma sucessão de exercícios com esta modalidade: o ator treina a visualização com a descrição verbal.

1. Vá até a janela e procure com os olhos; 2. Você vê uma balaustrada?; 3. E um pombo na balaustrada?; 4. Olhe para o pombo enquanto ele escapa e veja a sujeira que deixou; 5. Olhe atentamente para baixo da balaustrada; 6. Veja um carrinho com sacolas de supermercado; 7. Repare na cor do carrinho; 8. Uma criança está pulando corda; 9 . Olhe para os sapatos que ela calça; 10. Olhe para o homem que está empurrando o carrinho; 11. Veja de que maneira ele está vestido (ADLER, 2010, p. 41-42)

As impressões digitais resultantes implicarão as marcas das incidências deste verbo; porque o que o ator encena é a incidência dos materiais no corpo. Em Adler, marcas (desta incidência), vincos são criados com as respostas às perguntas e variações: "Ver especificamente. Ver rapidamente. Ver o que lhe prende a atenção. Ver atividades cotidianas e situa-las em circunstâncias específicas” (idem, p. 44). A fala externa em 
Adler se conjuga com a instrução: "Visualize o que falo!" - e já não se trata mais de fala externa apenas, mas de arranjo, pois o ator se dedica a "resolver o problema" da visualização.

\begin{abstract}
Descreva uma rosa. Se você diz "Eu vi uma rosa" e fala com seu parceiro sobre ela, deve esperar que ele veja a sua rosa. Se eu falo sobre uma rosa, a imagem da rosa é bem específica. Eu vi uma rosa. É vermelha e amarela e tem um longo talo verde com espinhos. Agora a rosa não é apenas um fato. Requer uma certa energia fazer seu parceiro ver o que você vê. Não basta que só você veja. Faz pare de sua técnica transmitir essas imagens ao parceiro (idem, p. 45)
\end{abstract}

Este tipo de visualização necessita de um tempo; e também de imobilidade. De maneira que se trata, de fato, de uma resolução formal específica. Mas algo da estrutura se deixa entrever: a função do anteparo a partir de um campo de extração específico. Adler associa o ator ao escritor.

\footnotetext{
O ator é como um escritor, cheio de impressões que o inspiram. Ele não anda por aí como um funcionário desocupado, dizendo: Vou comer bacon e ovos. Quando o ator compra bacon e ovos ele vê: a garçonete; a mesa; o restaurante em sua atividade agitada. $\mathrm{O}$ ator assimila tudo. Ele é capaz de ver que: o piso está sujo; a mesa não tem mancha; o café está fraco; ninguém está realmente prestando atenção em ninguém; todos estão com pressa (idem, p. 51).
}

O arranjo da atuação dramática conta não apenas com a plasticidade da ação, mas com a plasticidade do pensamento e olhar da personagem. Trata-se de plasticidade específica: alguém implicado na relação com o seu próprio pensamento, de maneira a revelar a divisão subjetiva: eu converso comigo. Kusnet evidencia que a articulação que entre duas cadeias (ações e pensamentos) gera o efeito de contradição da personagem. Esta proposição mostra a plasticidade do pensamento como diferente da partitura de ações (e se opondo a esta). O pensamento da personagem tem duplo estatuto: quando extraído do texto (como fala interna) ele é anteparo; quando evocado na cena ele é uma modalidade de enquadramento. No caso do trabalho com o texto dramático, o ator conta com uma modalidade de enquadramento fixo relativamente complexo e contínuo: a fala do texto dramático, que evoca imagens o tempo todo. Mas, o que o ator pode construir para evocar a plasticidade da sua relação com o seu pensamento? O que interessa é a evidencia de que o jogo entre enquadramentos diferentes define a especificidade de uma poética cênica. Stanislavski enfatiza também a plasticidade de uma relação com o outro: "Temos que estar sempre em contato com os outros em incessantes ajustamentos" 
(STANISLAVSKI, 1989, p. 243). ${ }^{3}$ Ele dá atenção especial ao que chama adaptações ou ajustamentos.

De agora em diante usaremos esta palavra, adaptação, para significar tanto os meios humanos internos quanto externos, que as pessoas usam para se ajustarem umas às outras, numa variedade de relações e, também, como auxílio para afetar um objeto. (idem, p. 240) ${ }^{4}$

O outro com quem se contracena é campo de extração. A leitura (ou a escuta) do outro pode situar o foco: "Terei de penetrar na personalidade do outro, pressentir sua vida, adaptar-me a ela" (idem, p. 241). Deste campo de extração que é o outro, o ator extrai detalhes (anteparos): "aqueles olhos extraordinariamente ingênuos, a boca grande, as mãos balofas e os gestos moles de um velho boa-vidas" (idem, p. 217). O ator produz materiais novos no momento da criação cênica a partir da leitura do outro, que entra em foco (enquanto a incidência de todo um arranjo é despejada na área de vulnerabilidade e se molda, ajusta, se adapta a este enquadramento). A plasticidade da relação com o outro é criada no jogo, em cena; um "entre dois" cujas entrelinhas podem ser interpretadas. $\mathrm{O}$ afeto implicado nesta relação é provocado por anteparos: "Podem parecer fora do alcance da evocação e eis que, de súbito, uma sugestão, um pensamento, um objeto familiar, trá-los de volta em plena força” (idem, p. 188).

O pensamento como instância isolável é uma modalidade específica porque se trata de evocar que a personagem está pensando. Cria-se a presença de algo "dentro da cabeça" com o qual o ator se relaciona: "eu converso comigo"; cria-se imagem acústica. Este paradigma está em Knébel: "El estudiante necesita aprender a actuar pensando" (KNÉBEL, 2005, p. 63); "La base en donde nace la idea es pensar, comparar, leer, mirar y vivir plenamente" (idem, p. 112). "Su pensiamento es siempre activo y concreto" (idem, p. 63); "El pensamiento se da en el cerebro en una forma muy compleja, abarcando todo ló variado de nuestra naturaleza orgânica" (idem). Trata-se de sustentar o improviso com o pensamento ou determiná-lo anteriormente, criando o que, no sistema stanislavskiano, chama-se "monólogo interior": "Eso nos lleva nuevamente al trabajo sobre el monólogo interno" (idem). No exemplo de Knébel, testemunha-se o indivíduo em relação com um pensamento que não expõe em voz alta, mas vibra: "Gorky describe com uma sorprendente fuerza lós pensamientos de Nílvna

\footnotetext{
3 Stanislavski oferece diversos exemplos de ajustamentos em STANISLAVSKI, C. A Preparação do Ator. Rio de Janeiro: Ed. Civ. Brasileira, 1989. pg 240-249.

4 Knébel transmmite alguns "exercícios de adaptação" em KNÉBEL, María. La Poética de la Pedagogía Teatral. México, 2002.
} 
incomunicables em voz alta, su lucha contra ela misma” (idem, p. 107).

\begin{abstract}
A mãe, satisfeita e cheia de orgulho, segurando a mala a ela confiada, espera na estação. $\mathrm{O}$ trem não estava ainda pronto para partir e ela teria que esperar. Depois de olhar ao redor, levantou-se e foi sentar-se em outro banco, quando sentiu que um homem a olhava como se a conhecesse. Esses atentos olhos produziram uma paulada no peito, a mão que segurava a mala estremeceu e esta se tornou pesada. "Eu há o vi em alguma parte!", pensou ela, criando com este pensamento uma vaga e desagradável sensação, sem permitir que outras palavras definissem o sentimento que lenta e poderosamente gelava o coração. A impaciência havia nascido e crescido em sua garganta e regado a sua boca de uma seca amargura. Ela desejava voltar-se mais uma vez. Fez isso e viu que o homem permanecia em pé no mesmo lugar, apoiando-se alternadamente em uma e em outra perna; parecia querer algo e não dizer-lhe. Sem precipitar-se, se aproximou de um posto e se sentou lenta e cuidadosamente, temendo revelar seu nervosismo. Sua memória, inquieta por causa deste súbito pressentimento de uma desgraça, colocou por duas vezes esta pessoa diante de si: uma vez no campo, fora da cidade, depois da ida de Rybin, outra no juiz. A haviam reconhecido, a seguiam, era certo (idem, p. $105-107)^{5}$
\end{abstract}

\title{
A palavra toma o corpo enquanto o ator conta com o abrigo (enquadramento)
}

de partituras físicas que implicam a plástica de um cotidiano diegético e a progressão dramática do conflito da personagem; evocando a plasticidade de imagens familiares, identificáveis. Um tipo de arranjo paradigmático na medida em que, durante a história da práxis atoral, as proposições de cada nova escola surgem em oposição a ele. Ele pode ser desmembrado e os materiais colocados em relação para formarmos outros arranjos, em experimentação.

Sabemos que lós pensamientos pronunciados em voz alta son solo uma parte de lós pensamientos que surgen em el consciente humano. Muchos de ellos no se pronuncian, y cuanto más comprimida sea la frase producida por grandes pensamientos, más saturada estará, mayor será su fuerza. (idem, p. 105).

5 Tradução própria de: "La madre, satisfecha y llena de brío, sujetando la maleta a Ella confiada, espera em la estación. El tren no estava aún listo, había de esperar. Echó uma mirada a la gente, despues se levanto y fue a sentarse em outro banco, más certa del andén, y de pronto sintió que um hombre la miraba como si la conociese. Esos atentos ojos la produjeron uma punzada, la mano que sujetava la maleta se estremació y ésta se volvió más pesada."iYo ló he visto em alguna parte!" - penso ella, creando com este pensamiento uma vaga y desagradable sensación em su pecho, sin permitir que otras palavras definiesen el sentimiento que lenta y poderosamente atenazaba com el frio su corazón. Había nascido y crecido em su garganta, llenado su boca de uma seca amargura, la impaciência. Le hacía desear bolberse uma y outra vez. Lo hizo y vio que el hombre permanecia em pie em el mismo sitio, aporyándose alternativamente em uma y outra pierna; parecia querer algo y no decidirse... Sin precipitarse, ella se acerco a un puesto y se sento lenta y cuidadosamente, temiendo revelar su nerviosismo. Su memória, inquieta por el agudo presentimiento de uma desgracia, coloco por dos veces a esa persona frente a ella: uma vez em el campo, em lãs afueras de la ciudade, después de la hida de Rybin, outra en el juicio...La habían reconocido, la seguían, eso era seguro” (KNÉBEL, 2005, p. 105107). 
Em Stanislavski temos a linha do pensamento (imagem acústicas subterrâneas para a sustentação do foco) e o enquadramento plástico corporal. Entre os dois, a área de vulnerabilidade, onde a impressão digital se forma.

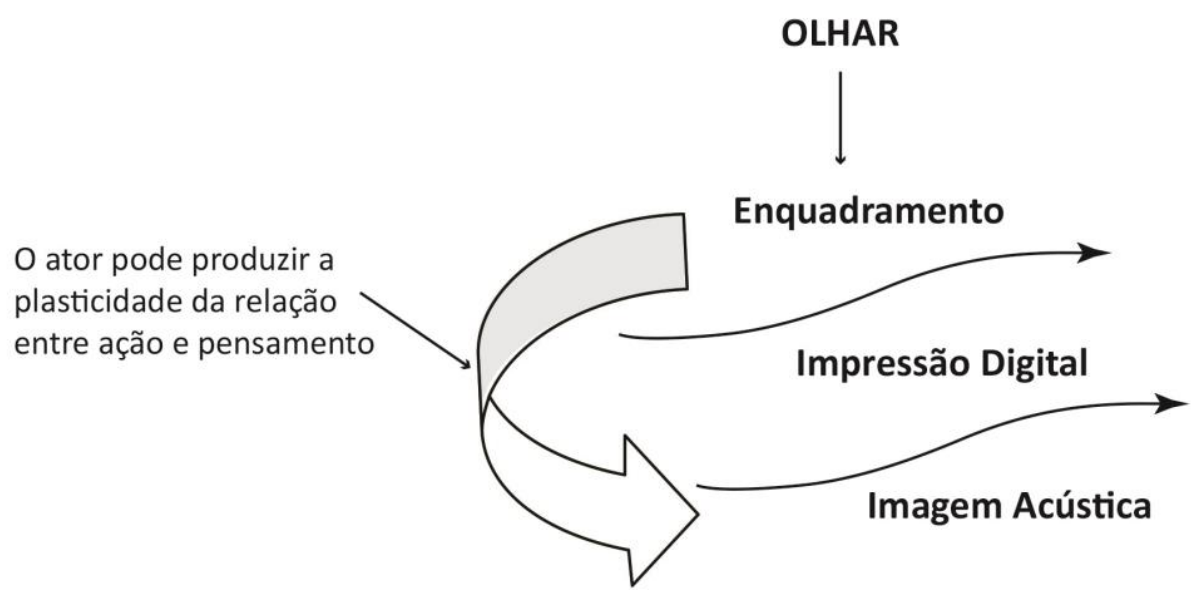

Figura 114: A Impressão Digital entre Enquadramento e Imagem Acústica

No ateliê, tenta-se tirar proveito desta fissura entre o enquadramento e a cadeia acústica subterrânea, mesmo que a modalidade de enquadramento seja outra e que a modalidade de imagem acústica também. Não se trata de um pensar que amarra a reação instantânea, mas de imagem acústica cuja incidência se dá neste tempo que Stanislavski chama "fração infinitesimal": mais rápido que as palavras (Knébel, 2005). A incidência sem o enquadre temporal. A incidência não está enquadrada no tempo-espaço da cena; é outra função. A partitura física torna-se necessária: bordeamento que pode ser oferecida também por uma sucessão de atividades cotidianas e uma situação ficcional cuja plasticidade ganha densidade.

No entanto, se nos propomos a explorar a singularidade dos arranjos, tal como Pavis indica com o termo performise (mistura de performance e encenação), resoluções novas podem ser investigadas. A poética corporal pode ora implicar uma plasticidade comum, ora extrapolá-la completamente, indo para uma abstração. Pode-se jogar com a composição de uma plasticidade estranha ao cotidiano junto à ficção cuja visualidade se densifica (utilizando outros recursos como projeções, o enquadramento com objetos na ficção); unir a incidência da imagem acústica ao movimento performativo de Bauch ou criar um corpo impuro, sujo da relação com o outro (sem a necessidade de ordenar as 
bordas): relativo caos. Não se trata da aplicação de um arranjo pronto, mas de investigar uma criação contingente.

\title{
5.1.3. Escrita e Redução: Articulação com Kusnet
}

A prática no ateliê se resume em exercitar o manejo das funções implicadas na estrutura e tirar consequência delas: usar a incidência da imagem interna; descobrir onde apoiar o foco; criar um jogo de tensões entre modalidades diferentes de enquadramento; reverberar a área de vulnerabilidade; usar diferentes modalidades de imagens acústicas. Vimos que, em Stanislavski, se encadeia o pensamento da personagem, constituído como monólogo interior. Kusnet propõe a redução deste monólogo, para que o ator chegue à fala interna. Esta fala interna é uma demanda: "Sai daqui!". É algo que "eu quero" - e se assemelha a um objetivo. Mas, é nomeado em primeira pessoa, para que a incidência seja eficiente; é curta e condensada. Ela implica a substituição de toda uma cadeia e um aumento da incidência. Uma cadeia muito comprida não pode entrar no foco. Reduzida, a fala interna entra no foco. Kusnet parte de cartas escritas de um personagem a outro:

\begin{abstract}
Muito importante também é o fato de que o ator, nessa forma de concentração, não deixa de agir fisicamente: ele escreve. Daí a organicidade desse processo no trabalho do ator. Comparem isto com a chamada "concentração mental". O ator, em estado de passividade física total, distraído pelo que acontece em seu redor, deve imaginar o diálogo, deve dialogar mentalmente com uma pessoa ausente. É evidente que isso é muito difícil para os atores pouco treinados em improvisações. O leitor já deve ter compreendido que o processo de escrever cartas é uma das formas de improvisação sobre um tema. Mas o que importa é o fato de que, devido à organicidade dessa forma, o ator encontra mais facilidade em adquirir a "fé cênica" na realidade da ação que se lhe propõe, ou em outras palavras ele chega mais facilmente a elaborar "uma instalação". Por isso, não é apenas para o efeito de concentração que ele deve usar esse recurso. Sendo uma das formas de improvisação, ele deve fazer parte dos trabalhos pelo método da “Análise Ativa". (...) A improvisação deve ser feita imediatamente depois do término da carta, pois um intervalo grande pode romper a integridade da linha de ação conseguida durante o processo de escrever. (KUSNET, 1982, p. 120)
\end{abstract}

"Enquanto escreve, fixa materialmente seus pensamentos" (idem, p. 127). A escrita ajuda o ator a criar o que ele chama de "instalação". Instalação de um jogo, onde a incidência está presente (esta produzida na escrita), as reverberações das suas cadeias: de letras que, repetida a grafia, implicam ritmo, movimento e as associações (jogo do significante), visualização e densidade da voz (que o ator produz); afeto em relação ao 
outro (para onde ele direciona a demanda, na medida em que está enquadrado por uma relação). Kusnet modaliza a instalação em "primeira" (o contexto do ator) e "segunda" (a ficção) sendo que a primeira evoca a segunda. No ateliê, a fala direcionada ao outro é uma maneira de entrelaçar a memória corporal do ator no enquadramento ficcional. As associações com a sua vida são usadas, numa espécie de ponte entre a memória corporal e o enquadramento, que por sua vez precisa estar cheio de incidência. $\mathrm{O}$ ator se apropria do contexto de jogo, porque é este contexto que faz incidência. Usa propositadamente os seus pensamentos. Não os do sujeito implicado na situação ficcional (construída pelo significante), mas os do sujeito implicado na situação de jogo. Então, o que se pensa pode ser inscrito na cadeia que constrói a plasticidade do mundo ficcional. A fala que se captura em nome próprio (no seu próprio contexto) pode ser deslocada para o contexto da ficção ("segunda instalação"). Evocando-o e mantendo-o articulado ao contexto do ator de maneira a enlaçar a pulsão e ativar algo pessoal, mesmo que o enquadramento seja estranho. Ou seja, começa-se a misturar, a substituir, a compor. O que se chama "fala interna" no ateliê implica esta redução que Kusnet propõe: o ator vai cortando as palavras, tirando, até chegar a uma sentença curta, imperativa, que situe o foco para improvisar.

\footnotetext{
A “carta” também passa pelo processo de condensação através das repetições nos ensaios, exatamente como acontece com a "visualização" e o "monólogo interior". (...) Com o correr dos ensaios eles se sintetizam, transformando-se finalmente em visões concentradas ao máximo, em símbolos ou exclamações em vez de frases completas. (idem, p. 127)
}

Kusnet propõe a redução, também, no trabalho com a imagem visual: " $O$ ator reduzirá sua visualização a detalhes mínimos, aos mais condensados, mais excitantes" (idem, p. 49). O ator extrai, da imagem, os significantes que o excitam. No detalhe, está implicado o corte com o fio da linguagem. A imagem visual torna-se campo de extração de anteparos verbais. O procedimento da repetição da escrita permite fixar "uma tripa" destas reduções. Os materiais produzidos por corte são enfileirados: temos uma subpartitura de falas internas condensadas, cada qual articulada a um arranjo. 


\subsubsection{Escrita e Memória Corporal: Um Treino na Imobilidade}

A substituição do "bater o texto" pela Memorização Através da Escrita é algo a se conquistar com um aluno acostumado à repetição oral. Este procedimento reverbera a necessidade de acomodar a palavra como impulso, incorporá-la, ao invés de fixar a cadeia do decorado. "Agarrem-se as palavras e frases isoladas de que tiverem necessidade, escrevam-nas e acrescentem-nas nos seus próprios textos livres. Evitem dizê-lo em voz alta para não tagarelarem mecanicamente e construírem uma série de acrobacias verbais" (STANISLAVSKI, 2005, p. 297). Stanislavski pede para o ator falar o texto com o "tra-lá-lá". Constituída, esta sonoridade pode estar, em um segundo momento, justaposta: na mesma posição de uma fala interna. O mesmo acontece com uma música que se cantarola em silencio: a fala externa se instala por substituição deste material. Um "tra-lá-lá" dividindo o foco de atenção, em escuta, pode ser tomado como exemplo deste lugar onde uma fala interna se situa quando escondida. É a operação de substituição que está em questão. Se fixarmos associações, vão implicar a fala externa como substituição ${ }^{6}$. São associações envolvendo a fantasia. Mas, muitas vezes, é preciso forçar a associação: procurar, dialogar, perguntar; criar chances para que as cadeias se desdobrem; para que significantes circulem na fala; para que movam a fala; e imagens apareçam diante dos olhos. Muitas vezes, construo, com os alunos, nos ensaios, as falas internas - de maneira que possam se apropriar e incluir nos seus pré-jogos.

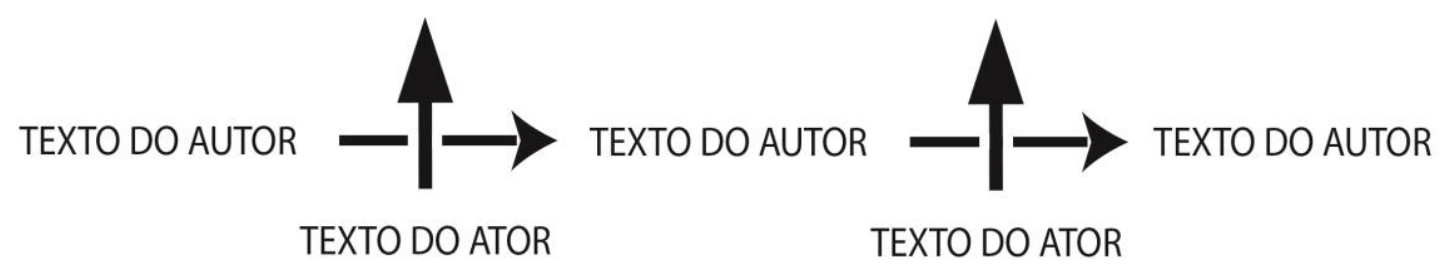

Figura 115: Fissuras na Fala Externa

É bom memorizar logo antes de entrar em cena. A repetição das palavras durante a memorização cria a densidade da voz que os aquece e impulsiona. Quando a

\footnotetext{
${ }^{6}$ Uta Hagen debate a operação da substituição em cena. Um exemplo é uma atriz que precisava sentir-se envergonhada. Ao substituir o material por "calcinhas sujas de menstruação" a ação "envergonhar-se" foi constituída. Ver: HAGEN, Uta. Técnica para o Ator: A Arte da Interpretação Ética. São Paulo, Ed. Martins Fontes, 2007.
} 
fala (externa) é enunciada, aparece como "segundo elemento" (e não o primeiro); deixa de ser o material onde o ator se apoia e passa a ser um material de enquadramento: solta, expulsa, caída (e não presa, segura). O impulso se inscreve justamente na troca entre os materiais: a fala externa substituindo à interna - que implica uma construção corporal (quando se tem repertório para instalar-se na área de vulnerabilidade).

A repetição da escrita: é como se fizesse uma massa, enquanto a cena é uma espécie de forno que faz crescer o pão (aquecido pelo olhar do outro). A massa é o acúmulo de reverberações do pré-jogo. As reverberações das palavras, escritas inúmeras vezes, reaparecem no corpo, para servir ao ato de improviso. Recentemente encontrei uma citação de Grotowski, que associa o que chama "ato total" a um manejo de um encadeamento de impulsos, que converge para certo momento, onde o ato total se dá uma espécie de sacrifício, de entrega. O pré-jogo pode ser comparado a uma espécie de manejo de uma cadeia de impulsos que pode "explodir" em cena; para que a intensidade cresça alinhavada àquela cadeia específica de materiais, como se a costurássemos no corpo. O pré-jogo é treinado justamente para ser esquecido. Ou seja, para ser atualizado fora do foco de atenção do ator. Ele ressurge, implicando uma espécie combustão com os materiais do instante-já. É apenas "um dos” materiais (que implica ordem, sucessão fixa, trilho, caminho de sucessivas trocas) cuja reverberação pode despertar uma tessitura corporal construída por atravessamentos. O improviso é sempre "outra coisa": a cadeia do pré-jogo está lá, mas ela se desloca para além dela mesma (como que desenrolando um tapete). O corpo vai um pouco adiante; cria algo diferente do registrado no papel; traz consigo ecos que aparecem no calor da cena. O que chamo de enquadramento é a organização espaço-temporal cujo limite se estabelece. Ele implica a necessidade de preenchimento, com a tessitura de espaços e tempos abertos que reverbera; implica uma abertura, uma fissura, defasagem entre os impulsos do pré-jogo e o tempo-espaço em cena. É neste espaço vazio que o ator cria - que o ator "entorna", ele "preenche" com a impressão digital, em sacrifício. $\mathrm{O}$ ator encontra-se munido dos impulsos do pré-jogo, mas, ao se deparar com este vazio, que esta defasagem implica, vai além, ocupando o espaço-tempo com a produção corporal que surge no instante.

Quanto à fala, procura-se evitar o "decorar". Evita-se esta sonoridade em blocos, difícil de aconchegar ou ser absorvida na ação. Evita-se que a sonoridade da fala seja constituída de maneira autônoma em relação ao enquadramento plástico-corporal. $\mathrm{O}$ enquadramento sonoro da voz deverá ser produzido em improviso. $\mathrm{O}$ ator fala pela primeira vez diante do olhar do outro, em ação, em movimento. A sua fala nasce pela 
primeira vez no forno aquecido pelo olhar do outro. $\mathrm{O}$ ator não fala antes. Antes de entrar em cena, apenas escreve. A oralidade é criada naquele instante de cena. Ela vem absorvida pela visualidade da relação que surge na hora. Da mesma maneira, a descrição das figuras extraídas das artes plásticas ou movimentos performativos também "vêm": aparecem, de maneira a ajudar a construir o enquadramento plástico-corporal. E são também absorvidas pela visualidade das relações e das ações que surgem de improviso. Da mesma forma, se queremos um tratamento plástico da voz, é necessário: ou anteparos pontuais ou repertório para entrar na área de vulnerabilidade.

Trata-se de operações que testemunham a intimidade entre linguagem, corpo e memória. Se as associações implicam o corpo e se, com a repetição, são alinhavadas, a sua reverberação se precipita, carregando, consigo, ecos que perdemos de vista. É como puxar um fio: os ecos se precipitam em cadeias. Na cena, as incidências se desenrolam em uma sucessão de impulsos e entram em relação com a fala dita pela primeira vez. A partitura física (o enquadramento plástico corporal) surge deste jogo e, só então, é fixado. Em cena, dá-se uma produção nova, filtragem naquele instante específico.

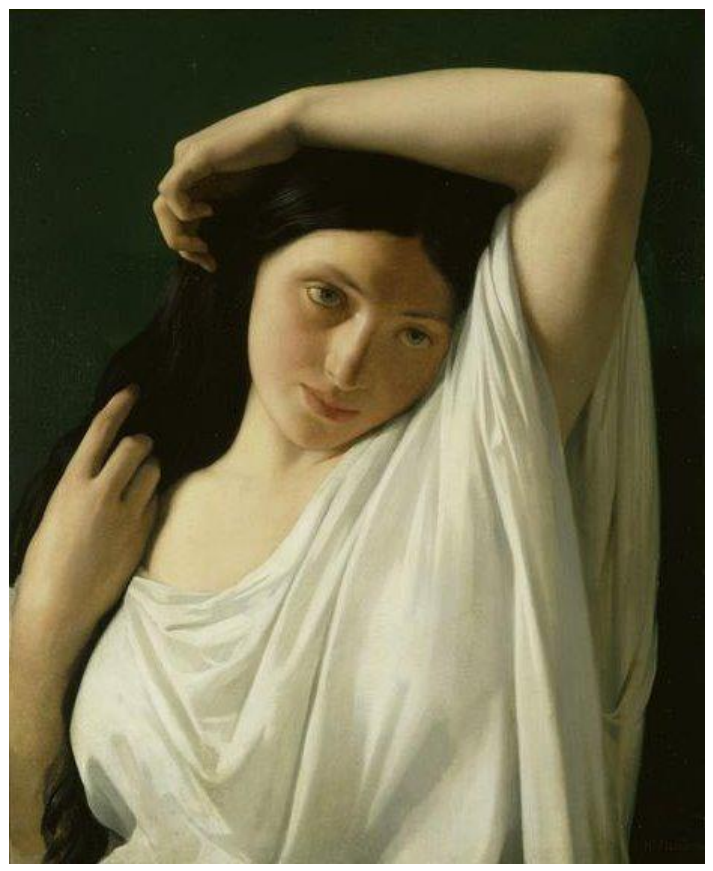

Figura 116: "Jeune Femme en Buste Dite La Florentine" de Hippolyte Flandrin (1809-1964)

Podemos alinhavar um lugarzinho para uma das figuras na escrita do pré-jogo, fixando o encontro com a fala interna e outra externa, criando uma espécie de acorde: empilhamento de três notas. Trata-se de fixar a reverberação deste acordes, em sucessão com os outros, criando um arranjo, tal como na escrita musical. Este processo é intuitivo (no sentido da criação, do improviso). E é singular, pois cada um escuta a figura de um 
jeito; nomeia-a e descreve-a de maneira singular no seu pré-jogo. Trata-se de encontros inesperados, pois, quando se olha, é de súbito (ou como por insight) que se vê uma ação. No entanto, fora da cena (no momento de criação do pré-jogo), não estamos na posição de encenar a incidência desses encontros no corpo. De maneira que é preciso alinhavar os acordes na memória da tessitura corporal (através da repetição da escrita) para ter a sua reverberação atualizada em determinado lugar da cadeia, como impulso, durante a cena.

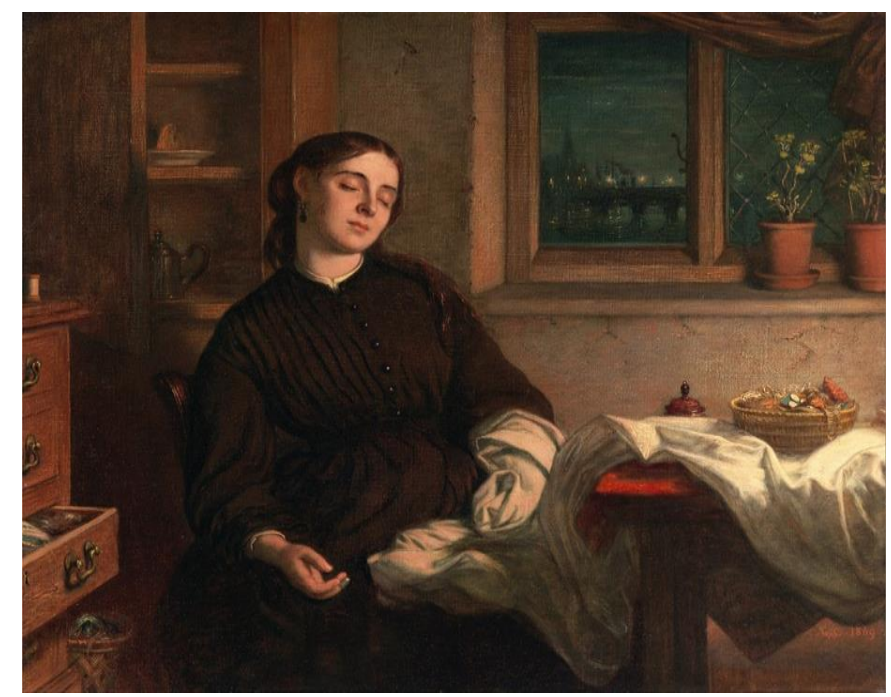

Figura 117: "Hope Dreams" (Charles West Cope, 1869)

Mas como esta figura, descrita em palavras (palavras que estão no papel), pode se reproduzir via reverberação corporal na fruição de um improviso bem naquele lugar a ela designado? A estratégia é repetir até a mão escrever sozinha (até não precisar mais do intervalo do tempo para lembrar). O fluxo vai para a cena. Uma possível explicação é que a imobilidade do corpo, no ato de escrever, porta-se como um enquadramento (limite) que potencializa a força do impulso para ações. O movimento da mão que escreve também faz oposição à fruição rápida das associações, potencializando o seu impulso, por oposição. O pulso da fruição experimentada na imobilidade tende a descompassar, estragar, borrar, romper a caligrafia. É o sinal de que o impulso está forte o suficiente para se precipitar em cena - e estragar, então, outro enquadramento: o cênico. 


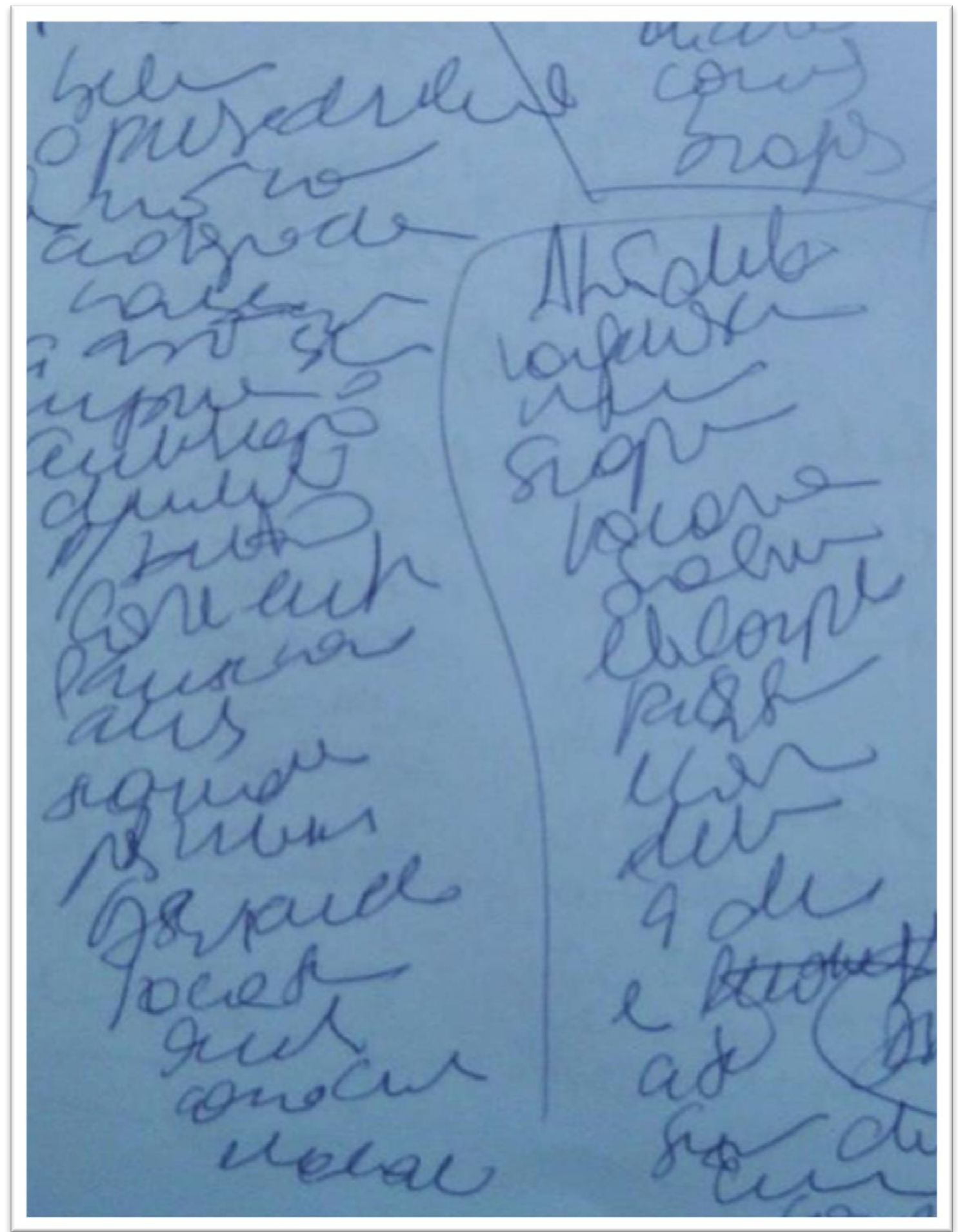

Figura 118: Pré-jogo “psicografado”.

Os impulsos implicam a dilatação da forma planejada em cena. Os limites da caligrafia corporal também são borrados, vencidos (gerando oscilação entre o desenho e a sua destruição). As sucessivas trocas entre palavras (uma substitui a outra naquela mesma sequencia) implicam saltos, fissuras, espaços - que, em cena, o ator preenche 
com a dilatação do corpo (para ocupar o tempo e espaço que, na cadeia escrita, não existia).

Devido à estranheza do procedimento, fui procurar referências (estranheza por ser muito diferente da repetição da partitura física e, também, da repetição da oralidade do texto). Encontrei muitas referências que me ajudaram. Não exatamente o procedimento que proponho, mas outros que podem ajudar a fundamentá-lo. Em Grotowski, encontrei não a escrita, mas a repetição do que ele chama "treino na imobilidade": não a repetição da partitura física, mas dos impulsos, quando o ator visualiza as ações da cena.

$\mathrm{O}$ ator começa esses pequenos impulsos, quase sem mover-se. Se nessa sequência dizia algo, o ator no início faz esses pequenos impulsos deixando correr o texto. Depois começa a dizer essas frases na mente, sem pronunciar as palavras, na sua cabeça, e quanto chega aquele fragmento que precisa realizar em plena ação. Tal preparação, na verdade quase estática, eu diria caracterizada por uma retenção dos impulsos, ou por impulsos contidos, não o colocará de modo algum em uma posição difícil para começar. Ao contrário, será como uma catapulta que o lança (GROTOWSKI, 2012, p. 220).

Existe em Grotowski uma noção de impulso retido, que, depois, explode, em cena; a noção de elaboração (e repetição) interna para, em um segundo momento, lançar-se. Esta noção implica o tempo anterior à entrada do ator em cena; um tempo de preparação, pré-jogo; da produção de uma cadeia. "Enquanto preparam um papel vocês podem trabalhar sozinhos sobre as ações físicas. Por exemplo, quando vocês estão em um ônibus, ou então, esperando no camarim antes de voltar ao palco” (RICHARDS, 2012, p. 108). Grotowski testemunha a diferença entre estas duas funções: a incidência (da imagem das ações ou palavras que as narram) e o enquadramento (plástico-corporal) em cena. As imagens podem atuar no momento em que o ator não está enquadrado pela cena (na partitura cênica), mas em outro lugar: no ônibus, camarim, na visualidade do cotidiano.

Quando vocês fazem cinema, perdem muito tempo esperando; os atores sempre esperam. Vocês podem utilizar todo esse tempo. Sem serem percebidos pelos outros, podem treinar as ações físicas, e tentar fazer uma composição de ações físicas permanecendo no nível dos impulsos. Isso significa que as ações físicas ainda não aparecem, mas já estão no corpo. Porque elas são "in/pulso". Por exemplo: em um fragmento do papel que estou fazendo em que estou sentado no banco de um jardim, uma pessoa está sentada ao meu lado, eu a olho. Agora, suponha que eu esteja trabalhando sozinho este fragmento com uma parceira imaginária. Exteriormente - não estou olhando para ela, eu a imagino - faço apenas o ponto de partida: o impulso de olhá-la. Da mesma maneira, faço o próximo ponto de partida: o impulso de me inclinar, de tocar a mão dela (o que Grotowski está fazendo é praticamente imperceptível) - mas não deixo que isso apareça completamente como uma ação, só estou começando. Você está vendo, eu quase não me movo, porque é apenas a pulsão de tocar, mas não 
exteriorizo. Agora eu caminho, caminho... só que estou sempre na minha cadeira. É assim que se pode treinar as ações físicas. Além disso, suas ações físicas podem estar mais enraizadas em sua natureza se vocês treinam os impulsos, ainda mais que as ações. Pode-se dizer que a ação física praticamente já nasceu, mas ainda está contida, e desse modo, em nosso corpo, estamos "colocando" uma reação certa (assim como alguém “coloca a voz"). (RICHARDS, 2012, p. 108-109)

Richards fala de pulsão: "a pulsão de tocar" quando o ator, em imobilidade, visualiza (e sente) a ação de tocar. Visualizar (ou escutar internamente enquanto repete a escrita) é experimentar a sua incidência sem ainda estar no enquadre espaço-temporal do desenho do corpo em cena. Neste momento de imobilidade, o enquadramento é dado pela posição em que o ator se encontra: no camarim, ônibus ou escrevendo (imóvel). A imobilidade oferece resistência - e esta resistência aumenta o impulso. Há uma relação de tensão entre incidência e enquadramento:

Em Stanislavski, encontramos as anotações no papel (da escrita): “Agora eu repito todas as ações que estão marcadas nessas anotações sem as executar fisicamente. No momento, vou me limitar a estimular e reforçar os impulsos que estão dentro desta ação” (STANISLAVSKI, 1993, p. 217 apud RICHARDS, 2012, p. 108). Há a proposição de que o ator anote os materiais de estímulo, criando um texto. Deparamo-nos com a presença da prática de escrever: criar outro verbo que não estava no texto do autor: "Quando chegarem à segunda leitura e às seguintes, tomem mais notas, recolham mais palavras para incluir no texto que vocês mesmos inventaram para seus papéis" (STANISLAVSKI, 2005, p._297)

Tal como no pré-jogo, trata-se de um revezamento de cadeias: o texto-dado junto a materiais do ator, que se tornam texto. $\mathrm{O}$ ator deve descrever tudo o que pensa, toca, ouve e vê em cena (Knebel, 2002): com quatro cadeias (o que vê, pensa, ouve e toca) que se revezam, cria-se um detalhamento; sucessão de ações. Encontrei um trecho onde Thomas Richards descreve o workshop de Cieslak $^{7}$ e a escrita novamente aparece. Os materiais são dispostos em duas colunas.

Cada um teria que pegar o próprio caderno de anotações, dividir uma página em duas colunas e escrever, em uma coluna, tudo o que tinha feito durante a improvisação; e na outra coluna, escrever tudo o que tinha associado internamente: todas as ações físicas, imagens mentais e os pensamentos, as memórias de lugares, as pessoas (...). Ele disse que através de tudo o que tivéssemos escrito em nosso caderno seríamos capazes de reconstruir, memorizar e repetir a improvisação que havíamos acabado de fazer (RICHARDS, 2012, p. 13)

\footnotetext{
${ }_{7}^{7}$ Ator de “O Príncipe Constante”, encenado por Jerzy Grotowski em 1965.
} 
Há o momento em que o ator não utiliza o enquadramento plástico corporal do espaço-tempo cênico, mas, pela escrita, fixa a imagem visual ou acústica para uma preparação ao nível dos impulsos. Vive-se a pulsação daquilo que ainda não se realizou. Há uma espécie de voz, que se materializa e se torna consistente com a repetição. A voz como espécie de ordem de comando, imperativo. O ator é objeto desta voz. Da mesma maneira que, em Spolin, um instrutor de jogo maneja a produção do ator com a sua voz, com a escrita repetitiva do pré-jogo, ele próprio constrói a voz à qual o corpo obedece na medida em que imprime seu eco. Voz articulada a imagens, que também incidem.

A visualidade de uma situação se afirma. Torna-se clara (jogo com o olhar) durante as repetições da escrita, tal como o quarto escuro pouco a pouco se enche de luz (Staniskavski, 2005). Existe a pulsão de ver; a operação do olhar; o quadro do olhar; a pulsão escópica: olhar para a visualidade de um contexto ficcional, que brilha (mas é o próprio olhar que brilha). E, também, a operação nonsense do som, que salta para outra coisa e faz graça.

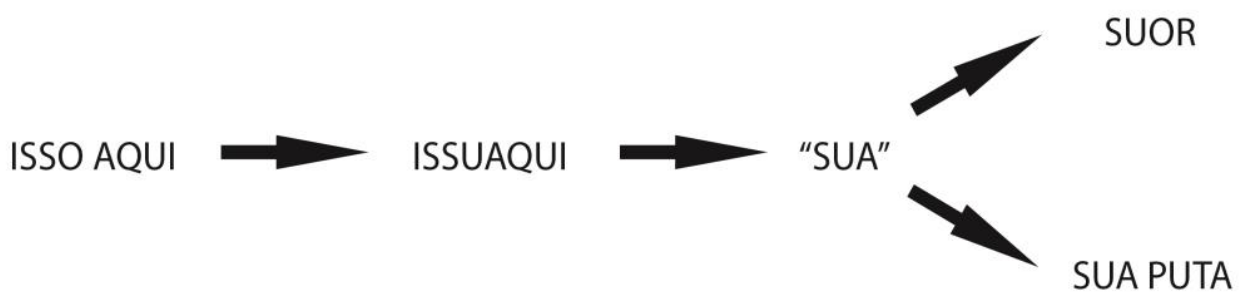

Figura 119: Exemplo de Cadeia Associativa

Como quando, de "isso aqui", chega-se a "sua puta" (ou "suor"), passando por "sua" - que está dentro de "isSUAqui". E outra maneira de compreender o procedimento é reconhecer a articulação entre palavra e corpo, tal como testemunha Merlau-Ponty: "Antes de ser o índice de um conceito, primeiramente, ela é um acontecimento que se apossa de meu corpo" (MERLEAU-PONTY, 2006, p. 316.). Vale a pena transmitir a citação inteira:

Um sujeito declara que, à apresentação da palavra 'úmido', ele experimenta, além de um sentimento de umidade e de frio, todo um remanejamento do esquema corporal, como se o interior do corpo viesse pela periferia, e como se a realidade do corpo, reunida até então nos braços e nas pernas, procurasse recentrar-se. Agora a palavra não é distinta da atitude que ela induz, e é apenas quando sua presença se prolonga que ela aparece como imagem exterior e sua significação como pensamento (idem). 
O exercício de memorização do pré-jogo através da repetição da escrita implica um jeito de se relacionar com o verbo e fazê-lo reverberar pelo corpo na medida em que a palavra incide. $\mathrm{O}$ fato de ser possível memorizar sem a compreensão do texto (pode-se memorizar um texto que não implique sentido algum), só pelo som (sem saber o que significa), indica que o ator conta com uma espécie de "cola". Uma cola que os "caquinhos" do verbo implicam. "Caquinhos" nas "junçõezinhas" entre palavras. Podese associar a palavra "suar" nesta brincadeira, apesar dela não ter nada a ver com "isso aqui" (com o texto das palavras em separado). São associações que a escrita viabiliza enquanto "passa cola". . Segundo Fingermann é com esta alingua que o poeta brinca: a “obscenidade do verbo” (Soller, 2010). A proposta é o ator poetar!

Outra operação que implica nonsense é a brincadeira e a imersão na grafia da letra, na pura arbitrariedade do desenho: a forma P ou J - que se saboreia e se destrói. Há tanto o jogo com o nonsense quanto com o sentido e os múltiplos flashes transitórios do jogo do significante. Enquanto o foco está na caligrafia (ou no gesto da mão que escreve), há um espaço aberto para as imagens acústicas e visuais que atravessam o ator de estalo.

5.2. Quantas tessituras serão necessárias?

O artista preserva a dimensão subjetiva ao apresentar um objeto que não dissimula sua falsidade, seu caráter de invenção. Um poema, uma sinfonia, uma obra de arte, são incapazes de recobrir o vazio; o vazio é parte integrante da criação que ousa contorná-lo

(Maria Rita Kehl)

5.2.2. Dois Homens e Uma Menina: Um pré-jogo que nasce quase pronto

Muitas vezes é preciso reconstruir (construir, destruir, lançar mão de resíduos, adicionar outros materiais): tecer de novo todo o pré-jogo. Há pré-jogos que demandam um processo longo de reformulações e outros que quase nascem prontos. É o caso da “Cena 3: Os Dois Pretendentes”. Iniciada a memorização de um fragmento da narrativa rodrigueana, "vem" a visualização do arranjo (e um enquadramento preciso): o barulho do coração com os dedos batendo no microfone; as sombras na parede (que representam 
o tio de criação e Jorge). O samba "Louco" na voz de Nelson Gonçalves veio na mesa da cozinha de casa, saindo da voz de meu ex-marido. Objetos (a caminha e os chapéus pendurados); os pensamentos pichados: "Entre nós a presença de uma morta". A ideia vem consistente, a visualidade (no olhar) e a pulsão de experimentar.

Após a experimentação no CEPECA, no momento da interlocução oferecida pelos pesquisadores, a cena torna-se um campo para a extração e associações aparecem. Na segunda apresentação para eles, sentada no chão, falo, no microfone, o que escrevo: as falas internas (que apareceram durante a Memorização Através da Escrita). Com elas crio um poema "maluco", aparentemente desarticulado: "Luciano ultrapassado. Frio? E agora? Já viu, né? Minha herança. Não quero mais. Vou encontrar a determinância. Tenho o poder. Há um lugar lindo. Que eu sinto. E mesmo que a lei não queira. Eu subverto. Sou culpada. Sim." Cada uma destas frases é a redução de um trecho de préjogo e tem sentido apenas em relação à parte da cena para a qual funciona como fala interna. O que parece nonsense implica sentido quando articulado à visualidade daquela ficção onde se inscreve (e que o enquadra, situa). Encadeadas, estas falas implicam uma sequencia de trocas. Nelas se pode colocar o foco, para que as falas externas apareçam na área de vulnerabilidade (fora do foco, como impulso). Acabei fixando-as na régua sonora e introduzindo-as na cena - a título de exposição. A cada instante de aparição da fala agora sonorizada, indica novo impulso para nova ação em cena. 
erovaquidauk de was

(12

inmia fale mere é

Rluarens ulragarsad

Luaroulrapaned
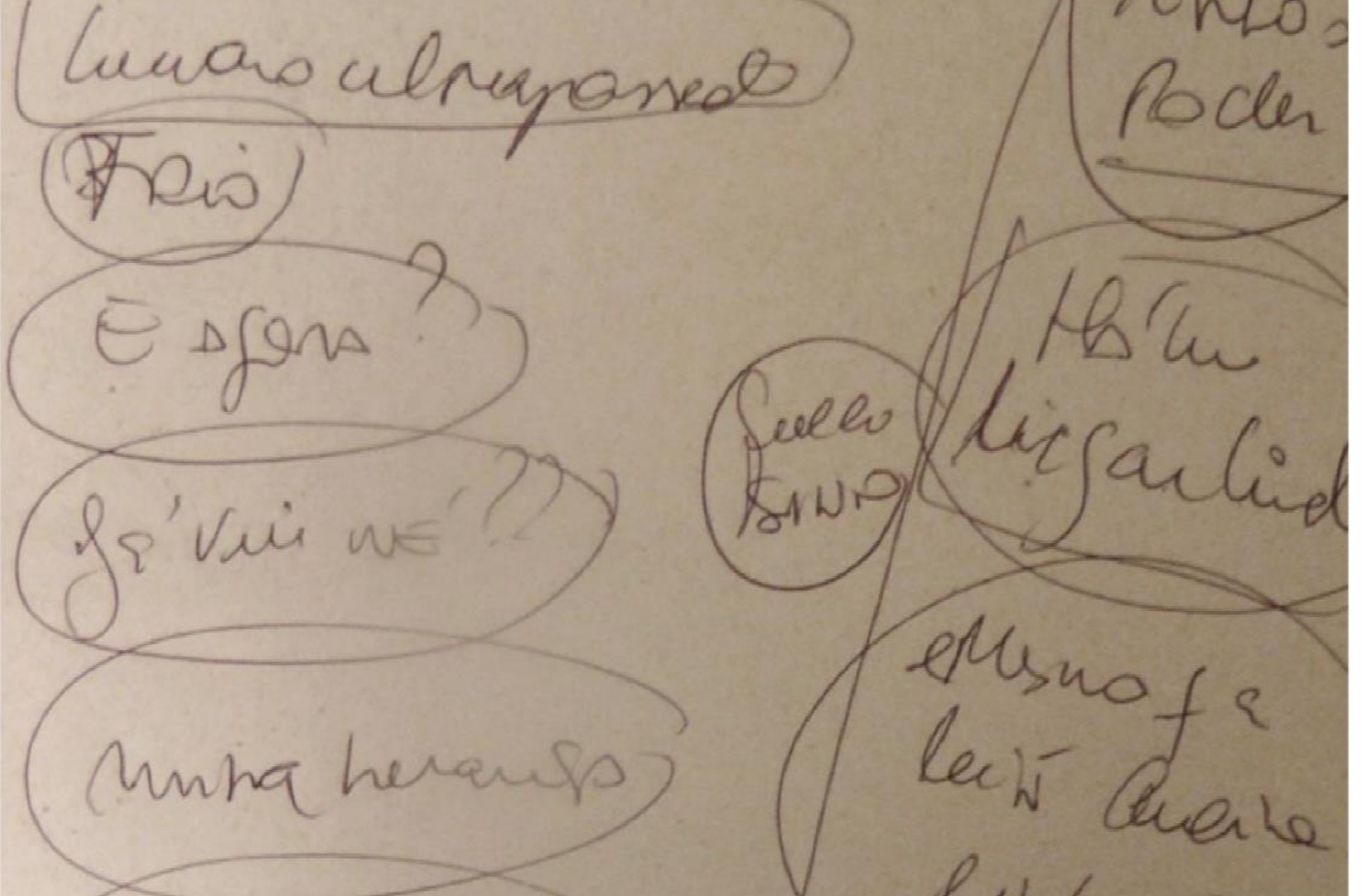

Mnha heraus

er bub

NQveo mais

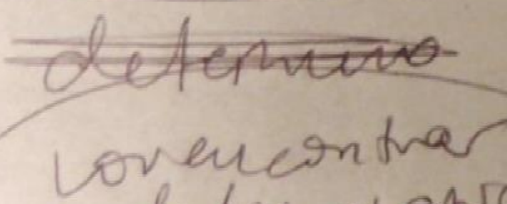

Sorgupads coferunaras Sui

Figura 120: As falas internas da “Cena 3: Os Dois Pretendentes” sendo memorizadas

190 


\section{FALA INTERNA}

\section{EM CENA}

Luciano ultrapassado

Frio

E agora?

Já viu, né?

Minha herança

Não quero mais

Vou encontrar a determinância

Tenho o poder

Há um lugar lindo

Que eu sinto

E mesmo que a lei não queira

Eu subverto. Sou culpada
Nada a ver com o menino com ar de bondade que fora criado com ela. Esperava qualquer marca de nostalgia, mas nada. Nenhuma dor (Para o chapéu sem parar o coração) - Jorge, se um homem gosta muito de uma mulher e ela morre, ele sente muito ou esquece logo? (Pausa. Recomeça) Jorge, faz de conta que um homem amou muito uma mulher. Um dia, ela se mata. Você acha que esse homem pode ter qualquer pretensão a filha da morta?

Pára a percursão. Larga o microfone. Põe a venda, assumindo a postura da avó

Santa mãe de Deus, Suzana! Ontem Jorge esteve aqui e pediu sua mão em casamento. E você, o que diz?

(Desce a venda e diz a medo) Eu aceito me casar com Jorge sim vovó!

Coloca a música. Andar rebolativo com a mão na cintura, reverência. Encaixa a cabeça, fazendo signo de homem: a postura esbelta, esguia e imponente. Saboreia a sombra projetada na parede. Com a mão esquerda acarinha a bonequinha que está sentadinha na cama. Ajoelha-se para fazer mais carinho e conversar com ela.

De repente, ela se vira e, agilmente, dá um empurrão forte no chapéu, como se fosse a menina, voa para a parede

Rasga o papel onde estava escrito 'Fiquei dias tremendo de febre. Ao meu lado, minha avó'. Aparece por baixo 'Entre nós, a presença de uma morta,

Observa a própria sombra. Constrói a enormidade de Aristeu, fazendo a sombra crescer quando se aproxima do projetor com passos ritmados. Sua figura cresce, cresce, cresce. Colocando o microfone entre as pernas. A sombra parece o sexo do tio

Você precisa passar um tempo na ilha comigo!";

Senti o hálito quente, o roçar da barba, mas ele só queria me beijar a testa como faz um pai

Não sabia que ilha poderia ser aquela, mas tinha a intuição de que lá conseguiria me livrar de Jorge

$\operatorname{Sim}$

Tabela 2: Falas internas na "Cena 4: Os Dois Pretendentes" 
Depois da memorização, à espera pelos pesquisadores, para me preparar, como uma espécie de aquecimento, experimento, vario (há alusão a enlouquecer também) movimentos extraídos de espetáculos de Bauch. Mas, o material que faz incidência é um batuque com os dedos no microfone (evocando o barulho do coração). Este som situa o foco. $\mathrm{O}$ seu efeito de incidência reverbera, transformando o corpo e constituindo um desenho corporal. A este desenho associo um happer (a imagem entra no arranjo, mas depois tiro). Coloco novamente o foco na fala interna. Novamente, o desenho do corpo se transforma. Em novo momento de variação, utilizo outro movimento de Pina Bausch: "passar a mão, de cima para baixo, diante do rosto" - do espetáculo "Vollmond (Full Moon)" (Pina Bausch, 2006). A incorporação deste movimento associa a máscara vincada para baixo, símbolo da tragédia (em oposição ao vinco da boca para cima, símbolo da comédia). Durante a apresentação para o CEPECA, a boca aberta reaparece evocando uma ação: é como se a personagem levasse um susto ao flagrar a presença da avó. Uma espécie de ruído do ar entrando nos pulmões pontua o gesto. O movimento aparece com a ação do drama revivido pela narradora. Conforme o foco, o movimento (que passa por corporificação e variação) é atualizado em cena. Observações:

$\checkmark$ “Andar rebolativo" é a nomeação de uma imagem extraída de um espetáculo de Bausch que associo (na Memorização Através da Escrita do pré-jogo). Na medida em que se amplia o acervo iconográfico com um campo que nos apaixona, as associações aparecem com facilidade: seja durante a escrita, nas variações do aquecimento ou no experimento diante do outro. A imagem do movimento é enquadrada na ficção: "um jeito insolente de ir até Jorge".

$\checkmark$ A fala "minha herança" tem uma conotação especial para mim; associação que não implica a plasticidade do olhar do espectador (é material de incidência): neste campo de associações pessoais, a "minha herança” é a sexualidade. Mas, resultante de uma série de cortes, a expressão implica, também, a condensação do que ficou para fora e não foi textualmente nomeado. Durante a repetição da escrita, fixo a reverberação de "minha herança" em certo local da cadeia escrita para que o impulso reapareça em cena em lugar pré-determinado. Em cena, o foco de atenção se situa no samba. Em outro momento, o foco de atenção vai para a mão que, na sombra, acarinha a bonequinha. Muitas vezes, o foco de atenção se situa em materiais de enquadramento, mas o imaginário, um sentido 
que elaboro para as ações, também estimula: o corpo da menina (representada pela bonequinha) torna-se objeto de deleite dos adultos.
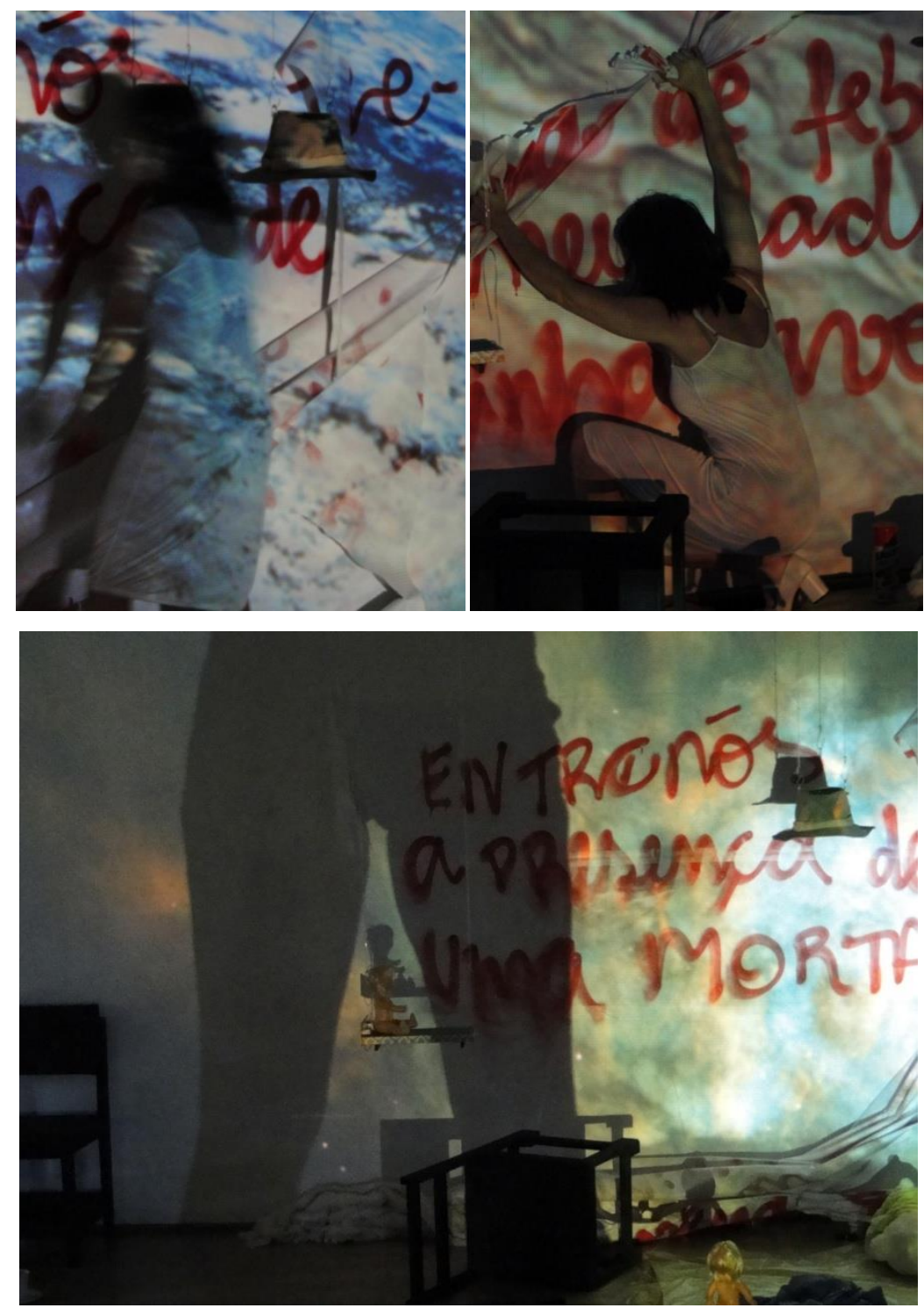

Figura 121: Momentos da "Cena 3: Os Dois Pretendentes"

A ideia de colocar o microfone entre as pernas enquadrando-o como o membro de Aristeu surge da interlocução no CEPECA. O tempo da brincadeira com o membro pendurado é dilatado na experimentação de variações antes da cena. Implicado está o quem “escritora” experimentando objetos para criar histórias. O sentido deste quem me ajuda a assumir certas ações e dilatar os tempos, pois 
há a sustentação deste enquadramento, imaginário (um anteparo propriamente) para os desdobramentos dos efeitos de incidência.

$\checkmark$ Surge também um vestido de noiva: objeto que serve como enquadramento - e por vezes se opõe a outros. Ele atrapalha a brincadeira com o membro. Preciso levantar a saia. Isto resulta em uma figura arqueada. A presença do vestido me obriga a modificar a ação: antes caminhava, pouco a pouco, em direção ao refletor, fazendo a sombra crescer, enquanto jogava com a fala interna " $A$ sua figura cresce, cresce, cresce" - criando um ritmo. Passo a constituir a sombra apenas na posição final, onde a figura de Aristeu aparece de repente. A ação de brincar é deslocada para o momento seguinte: antes, compondo a figura; agora com a figura já composta, brinco com a imagem do membro (deslocamento de um material na cadeia).

Marcas reaparecem: além dos materiais fixados no pré-jogo, a plasticidade da imagem da voz de outra atriz me invade em cena. Um testemunho de que a impressão digital, sem querer, pode atualizar algo que vemos em outros e causa incidência em nós (mesmo sem o treino). Trata-se de um material isolado e não encadeado, no entanto. Já o pré-jogo funciona como uma cadeia de incidências fixadas em ordem. O resíduo de certo treinamento realizado - físico (barbiano) para a dilatação corporal - também reaparece.

$\checkmark$ A ação de "olhar o espectador no olho" surge também. Acredito que adveio de um procedimento de Adler, que havia sido associado para o início espetáculo, onde eu olhava um por um. Isto veio em imaginação fora de cena. Reapareceu no experimento cênico no CEPECA, só que em outra cena: um deslocamento. Acredito que, estando o corpo atravessado pela incidência desta ação (olhar a plateia), com “e mesmo que a lei não queira, eu subverto" foi criada uma ação: buscar a cumplicidade para o ato de subversão.

No final, depois de apagar as frases da avó no quadro negro para dizer "Sim" ao tio, eu deveria encenar a avó, dando um ataque, tal como Nelson Rodrigues narra. Mas este trecho não tinha sido repetido pela escrita (tampouco eu tinha trabalhado falas internas para ele) e parei. Ele simplesmente não veio; não apareceu e eu parei a cena. Em interlocução com o CEPECA falei: "Não quero mais um chilique da avó". Esta fala foi fixada na régua sonora. A cena deveria terminar com um grito ("Canalha!") junto ao último acorde do samba "Louco", para, em seguida, ser invadida pelo silêncio. Coloquei na régua sonora: "a cena 
é invadida pelo silêncio agora". Acredito que este arranjo permite ver uma sucessiva incorporação de materiais de bastidor e a perspectiva do improviso, mesmo com o pré-jogo fixado pela repetição da escrita (que cumpre a função de atualização de impulsos). Há fissuras onde novas coisas entram - coisas que tinha atravessado o corpo com a sua incidência em algum momento.

Entra legenda "Três: O Pretendente". A imagem da família em luto dá lugar a sucessão de imagens de planetas - extraídas do descanso de tela do computador. Rejaniana. Tira a vara com as bonecas, deixa as no chão. Tira a saia, senta a bonequinha na cama. Apanha o microfone. Com os dedos, evoca o barulho de um coração.

SUZANA (para o público): Nada a ver com o menino com ar de bondade que fora criado com ela. Esperava qualquer marca de nostalgia, mas nada. Nenhuma dor. (Para o chapéu, sem expressão e sem parar o coração): Jorge. Se um homem gosta muito de uma mulher e ela morre, ele sente muito ou esquece logo? (Tempo) Jorge. Se faz de conta que um homem amou muito uma mulher. Um dia, ela se mata. Você acha que esse homem pode ter qualquer pretensão a filha da morta? (Pára a percursão. Larga o microfone. Põe a venda, assumindo a postura da avó) Santa mãe de Deus, Suzana! Ontem Jorge esteve aqui e pediu sua mão em casamento. E você, o que diz? (Desce a venda e diz a medo) Eu aceito me casar com Jorge sim vovó! (Ela voa para a parede e rasga o papel onde estava escrito "Fiquei dias tremendo de febre. Ao meu lado, minha avó”. Escreve, com o spray: "Entre nós, a presença de uma morta”. Ela vai até o chapéu e encaixa a cabeça, fazendo signo de homem: a postura esbelta, esguia e imponente. Saboreia a sombra projetada na parede. Com a mão esquerda acarinha a bonequinha que está sentadinha na cama. Ajoelha-se para fazer mais carinho e conversar com ela. Mas, de repente, ela se vira e, agilmente, dá um empurrão forte no chapéu, como se fosse a menina. Observa a própria sombra. Nota que pode construir a enormidade de Aristeu. Grita) Dona Martaaaaaa! Seu Aristeu chegou! (Fazendo a sombra crescer, se aproxima do projetor com passos ritmados) Sua figura cresce, cresce, cresce. (Agacha-se, fazendo com que a sombra invada a caminha) Senti o hálito quente, o roçar da barba! (Põe-se novamente em pé. Colocando o microfone entre as pernas. A sombra parece o sexo do tio. Esclarece a plateia) Mas ele só queria me beijar a testa como faz um pai. (Distorcendo a voz no microfone) Você precisa passar um tempo na ilha comigo! (Para a platéia) Não sabia que ilha poderia ser aquela, mas tinha a intuição de que lá conseguiria me livrar de Jorge. (Calma e prazer) Vovó perdeu completamente a compostura. (Entra "Louco", de Nelson Gonçalves. Ela se joga no quadro-negro, apagando, com os braços, as frases da avó e escrevendo, por cima, a sua resposta ao tio: "Quando?") Apago. Escrevo. Me visto. Ajoelho. Passo por trás do varal. (Segue as ações. Com a vara nas costas, pragueja, rastejando de joelhos, invadindo o espaço em direção ‘a platéia) No casamento do seu pai, santa mãe de Deus, Aristeu invadiu a igreja gritando "Ela vai te trair, ela vai te trair!!" Pai nosso que estás no céu! Nunca vi homem tão parecido com o demônio!! Veio aqui pra me humilhar!! Fez isso pra me humilhar!!! (Finaliza com um grito) Canalha!!

Utilizo uma fotografia de uma família em luto (contrastando com a fantasia sexual da menina). Esta associação é um anteparo para mim. 


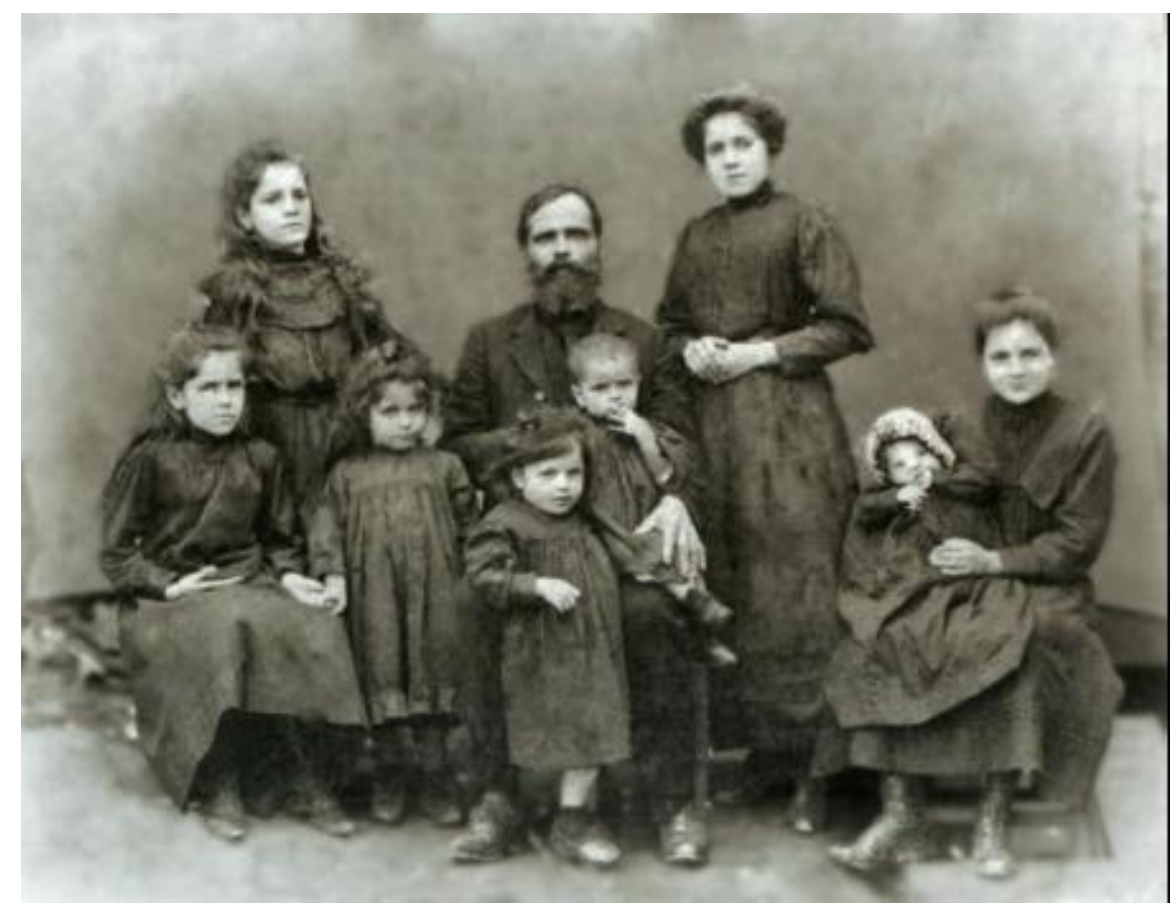

Figura 122: A Família Rodrigues (Fonte: acervo de minha avó Sueli Bittencourt)

\subsubsection{A Vingança: Tomada de Decisão na Reformulação do Pré-jogo}

Escrever é correr o risco da ausência de tempo, onde paira o eterno recomeço. É passar do Eu ao Ele. É dispor da linguagem sob o fascínio e por ela, em ela permanecer em contato com o meio absoluto, onde a coisa se torna imagem, onde a imagem, de alusão a uma figura se converte em alusão ao que é sem figura e, da forma desenhada sobre a ausência torna-se a presença informe dessa ausência, a abertura opaca e vazia sobre o que é quando não há mais ninguém, quando ainda não há ninguém.

(Blanchot)

A construção extra-cotidiana no ateliê implica também a de um corpo "sujo" que, com a cotidianidade, evoca uma realidade passível de estar acontecendo naquele momento (e é também representação da escritora compondo o seu mundo, apesar de implicar a performatividade). A visualidade do processo está impressa na tessitura da cena enquanto circunscrita por um superobjetivo: mostrar a incidência da voz que ganha consistência (vai se avolumando e se adensando) quando o ator repete a escrita do préjogo em função da memorização. É uma instância isolável. É possível se relacionar com esta diferença, este "outro-voz" como se viesse de fora. Esta voz pode figurar um lugar "dentro e fora" que Lacan designa por "êxtimo": “(...) o que nos é mais próximo, 
embora nos seja externo. Seria preciso criar a palavra êxtimo para designar aquilo de que se trata” (LACAN, 2008, p. 219); “(...) num lugar que podemos designar como sendo êxtimo, conjugando o íntimo com a exterioridade radical" (LACAN, 2008, p. 241). Mas é oculta; material que só o ator escuta, portanto é difícil demonstrá-la. Um dia, deixo o pré-jogo escapar a viva voz e tenho a ideia de grava-lo para pô-lo em cena, inteiro, como voz sonorizada; como um objeto fora do corpo - caída, fora de mim. A "Cena 9: A Vingança" começa com as palavras do pré-jogo ditas de forma verborrágica, (tal como falas de Heiner Müller) ${ }^{8}$.

\begin{abstract}
Braços de bateria com 'porra' é claro! Jogo de escolha: que o assassino ia querer acabar com a vida da testemunha; ia acabar com ela; ia matar ela; ia calar a boca dela. O olho desfoca. Devagarinho o cotovelo, protegendo os seios, o sexo e o rosto e escapa dos tapas. E com toda a sua força. Movimento dos gestos rápidos bem na frente do rosto com as duas mãos na cocha. Estava tudo escuro ela não enxergava nada. Ele disse que matou por ela. Caminha de salto alto, vai até a mala, pega uma maçã e come. (Ela vai pegar o sapato alto que está junto ao vestido azul). Pensando: Ele disse que matou por ela. Ele imobilizou a cabeça dela. Segura forte nos cabelos com a mão direita. Ela travou os dentes e disse: Ah é? Você quer? Então vem. E ela se entregou a ele sem nenhum frêmito. E com uma felicidade dramática ela pensou que tinha vingado a mãe.
\end{abstract}

A fala sonorizada no início da "Cena 9: A Vingança” é paradigmática do que "Casa" é em termos de estilo: uma exposição em função de uma pesquisa. Nela estão: pensamentos (“porra", “é claro!”) e instruções de jogo (“jogo de escolha”), nomeações ("braços de bateria") e descrições de corpo ("devagarinho o cotovelo, protegendo os seios, o sexo e o rosto com as duas mãos na cocha") - misturados ao texto rodrigueano: "Estava tudo escuro e ela não envergava nada". Um texto fragmentado, porque pego as frases que mais fazem incidência: "Ele imobilizou a cabeça dela". Na fragmentação e instalação de descrições de corpo, falas internas, nomeações, etc, a visualidade da progressão de uma situação se perde. Há a dilatação de gestos e a exacerbação de uma fantasia: a luta (com o ar), como se ela fosse uma gata brava (com algo que está diante dela). A plasticidade corporal acaba por prevalecer. Há também uma imagem extraída de Bausch que implica a cotidianidade: a atriz-bailarina comendo, displicentemente, uma maçã - e cuspindo pedaços no chão (cotidianidade subversiva). São arranjos que se alternam.

\footnotetext{
${ }^{8}$ Hiner Müller, dramaturgo alemão, é um dos autores considerados pós-dramáticos. Mistura fragmentos e referências advindas da literatura ou outras dramaturgias, propondo releituras de mitos e tragédias, transformando o material de origem. Suas principais peças são: Medeia Material, Hamletmaschine, Quartett.
} 


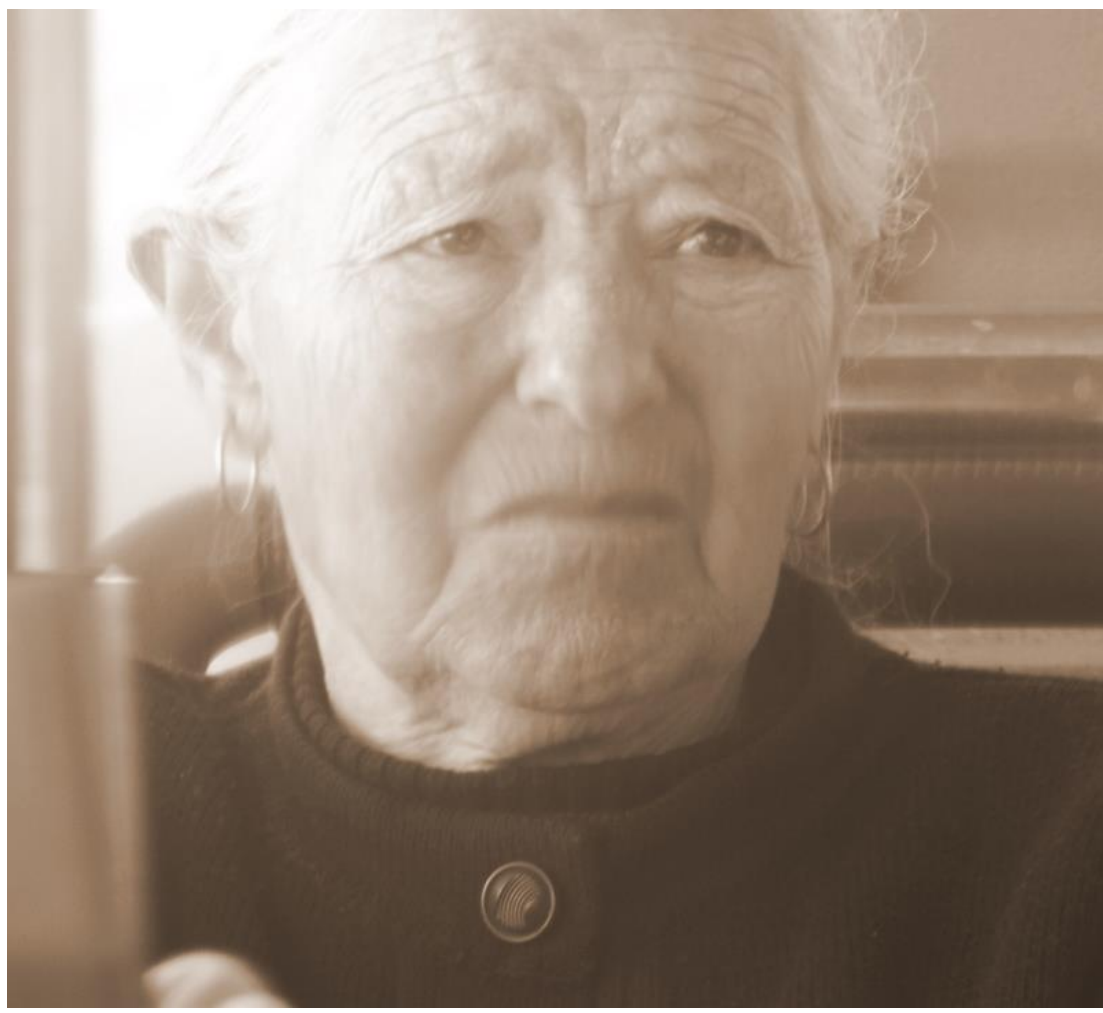

Figura 123:

Alusão à avó

(acervo pessoal).

Na projeção, está a fotografia de uma senhora, que associo à avó de Suzana. É como se ela estivesse olhando o estupro; é como se a narradora dissesse: "Está vendo a irresponsabilidade, no que deu?" É a fantasia atuando; uma fala interna. Stanislavski testemunha um arranjo sustentado por uma fantasia (uma única frase): "E se eles me abrirem mesmo?"

Certa noite, numa festa em casa de amigos, fazíamos várias brincadeiras e, por pilhéria, resolveram operar-me. Trouxeram mesas, uma para a operação e outra com supostos instrumentos cirúrgicos. Penduraram lençóis, trouxeram ataduras, bacias, muitas vasilhas. Os cirurgiões envergaram aventais brancos e eu fui metido numa camisola de hospital. Estenderam-me na mesa operatória e vendaram-me os olhos. O que me perturbava era a atitude extremamente solícita dos médicos. Tratavam-me como se eu estivesse desenganado e tudo o que faziam era com a maior gravidade. Súbito, a ideia me riscou pelo cérebro: 'e se eles me abrirem mesmo?' A incerteza e a demora afligem-me. O meu senso auditivo aguçou-se e tentei não perder sequer o menor ruído. Ouvia-os, por toda parte, cochichando, despejando água, fazendo tilintar os instrumentos. Volta e meia uma grande bacia retumbava, lembrando o dobre de algum sino fúnebre. 'Comecemos', sussurrou alguém. Alguém segurou com firmeza o meu pulso esquerdo. Senti uma dor surda e depois três fortes espetadelas... tive de estremecer. Esfregaram no meu pulso uma coisa áspera, que ardia e, depois o envolveram em ataduras. Eu ouvia o rumor de pessoas que entregavam objetos ao cirurgião. Afinal, após uma pausa, puseram-se a falar algo, riram, cumprimentaram-se. Desvendaram-me os olhos e vi, aconchegado em meu braço esquerdo... um recém-nascido. Nas costas da minha mão eles tinham pintado uma cara tola, infantil. (STANISLAVSKI, 1989, p. 297-298). 
A fantasia é sustentada por uma frase que faz incidência: "e se eles me abrirem mesmo?" - enquanto o foco se divide com os materiais externos (o cochicho, a água que é despejada, o tilintar dos instrumentos, as vozes). Em "Casa" há um arranjo entre vozes internas e sonorizadas, uma música do Led Zepelin e uns tantos coxixos na sonoplastia, que se intercalam à voz falada; há uma história de vida da Rejane, citada textualmente: barroquismo. Às vezes condensadas, perdendo contorno e identidade, borrando-se e se misturando.

Senta-se para calçar o sapato.

MULHER: Eu era uma menina solitária, vagueando pelas ruas da Praia de Canasvieiras em Florianópolis. Pegava fruta no pé, roubava cana-de-açúcar. Uma vez eu desafiei o meu irmão para enfiar a cabeça dentro de um aro de madeira que tinha numa cadeira de balanço lá de casa. Ele enfiou e não conseguia mais tirar. (Junto ao murmúrio da voz) Uma vez eu cheguei em casa e minha mãe estava toda machucada. Ela disse que ladrão entrou e bateu nela. Eu cheguei a desconfiar que era mentira. Que meu pai é que tinha batido nela. (Braços de bateria com 'porra'). É claro que o assassino (jogo de escolha) ia querer calar a boca dela! ( $O$ olho desfoca e devagarinho o cotovelo protegendo os seios e o sexo e o rosto escapa dos tapas e com toda a sua força.... Eu sentia a respiração dele! Movimento de gestos rápidos bem na frente do rosto.. As duas mãos na cocha) Estava tudo escuro, ela não enxergava nada! Ele disse que matou por ela! (Caminha de salto alto. Vai até a mala. Pega uma maçã e come. Comendo e cuspindo. Comendo e cuspindo. Pensando: Ele disse que matou por ela. Larga a maçã). Ele disse que matou por ela... Ele imobilizou a cabeça dela. (Comendo e cuspindo) Ele disse que matou por ela... (Segura forte nos cabelos com a mão direita. Trava os dentes. $E$ diz) Segura forte nos cabelos com a mão direita, trava os dentes e diz: “Ah é? Você quer? Então vem!"... E ela se entregou a ele... sem nenhum frêmito. A mãe também se entregou. Mas ela, sem nenhum frêmito. E com uma felicidade... dramática... ela pensou que tinha vingado a mãe!... E com uma felicidade dramática...

Entra Led Zeplin.

AUTORA: Ela pensou que tinha vingado a mãe!

A Criação do Pré-jogo

A angústia parece ser um afeto recorrente: ela testemunha algo que não se pega, não se sustenta; que foge; não se encontra. Com forte apelo, pode provocar a reconfiguração de todo um arranjo, na medida em que toma o corpo e chama ao ato, a uma decisão. Descrevo os materiais de Bausch para articulá-los à ficção rodrigueana; revezo momentos de escrita e idas à cena; escrevo, reescrevo, mas não me convenço: o arranjo não faz incidência. Aparecem tantas possibilidades; é vertiginoso - e, junto, uma 
sensação de fracasso: eu não ia conseguir. Abandono o que tenho e mudo tudo. Começo por um jogo de escolhas de falas. Em cena, devo escolher entre: "ia acabar com a vida dela", "ia acabar com ela", "ia querer acabar com ela" ou "ia matar ela, ia calar a boca dela". Descrevo uma imagem da cena "Pina, Nelson, Kieslowski e eu": "E devagarinho o cotovelo, protegendo os seios e o sexo e o rosto, escapa dos tapas" - e me lembro do procedimento das visualizações de Stella Adler. Mas, visualizar o quê? "Primeiro eu na frente deles; os olhos fixos em uma imagem que não encontro; não sei qual é": não saber o que visualizar torna-se ação (assumo o meu contexto). Alguns dos movimentos de Bausch retornam ao pré-jogo. Ao repeti-lo (para memorizar) lembro-me de episódios da infância e começo a inventar.

\begin{abstract}
(O que eu vejo?) Lá na praia eu sou uma menina solitária. Vagueio pelas ruas de Canasvieiras, pego fruta no pé, roubo cana-de-açúcar. Uma vez eu desafiei o meu irmão para enfiar a cabeça dentro de uma de uma cadeira de balanço. Ele enfiou e não conseguia mais tirar. Uma vez eu cheguei em casa e minha mãe estava toda roxa. Disse que ladrão tinha entrado e batido nela. Eu cheguei a desconfiar que era mentira. Que meu pai que tinha batido nela.
\end{abstract}

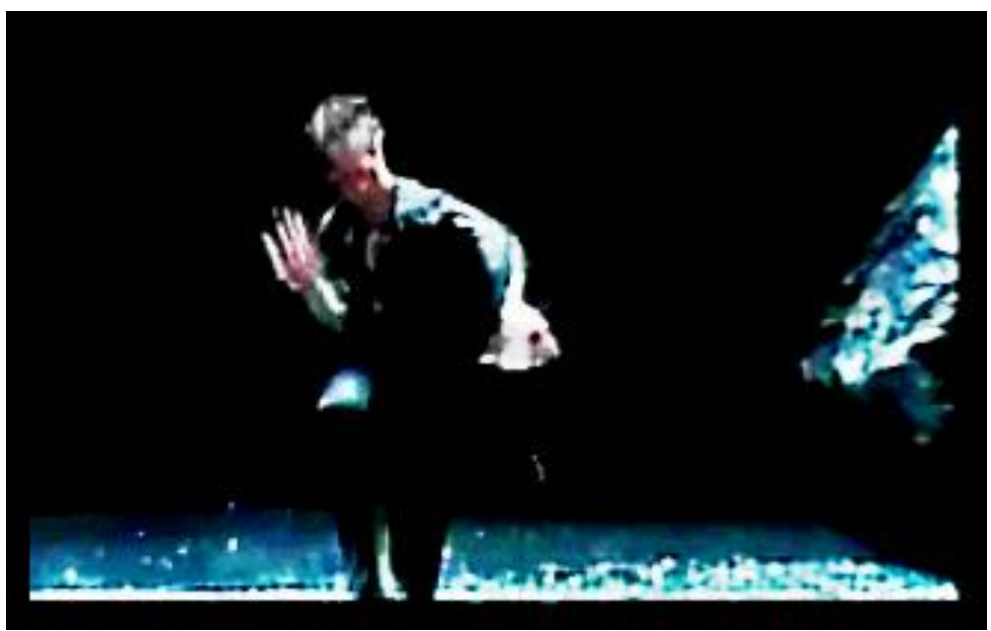

Figura 124:

"Braços de

Bateria"

(frame do

vídeo)

Aos moldes do exercício de Knébel (escrever tudo o que se ouve, toca, vê e pensa em cena) memorizo o pré-jogo pela repetição da escrita para deixar bem firme a imagem acústica oculta, como caminho para a produção de uma visualização, já que “palavras evocam imagens" (Rancière, 2012). O pré-jogo é memorizado nos instantes anteriores à entrada em cena. A cadeia verbal reverbera e deixo escapar a fala interna, que deveria permanecer oculta e se une ao movimento de Bausch "braços de bateria" 
- evocando a ação da descoberta (“É claro!”) - enquadrada pelo movimento formal, plástico, para além da ação que evoca. A memória de infância termina com "eu achei que meu pai tinha batido nela" - que, em cena, articula: "É claro que o assassino ia querer acabar com a vida dela!". Com um material do contexto do ator fixado (na memorização) surge ação nova no contexto da ficção. A primeira instalação evoca a segunda instalação: o contexto da personagem (Kusnet, 1992). A associação entre os dois contextos é súbita; há invasão repentina do olhar.

A apropriação do movimento (que se intromete na área de vulnerabilidade) implica: mimetização, repetição e variação, junto a falas internas ("Sai" ou um som "rrrrrrrr") - e uma imagem (o hálito do homem). O movimento "Braços de pássaro" resulta irreconhecível; diluído em função do arranjo (e do processo de apropriação).

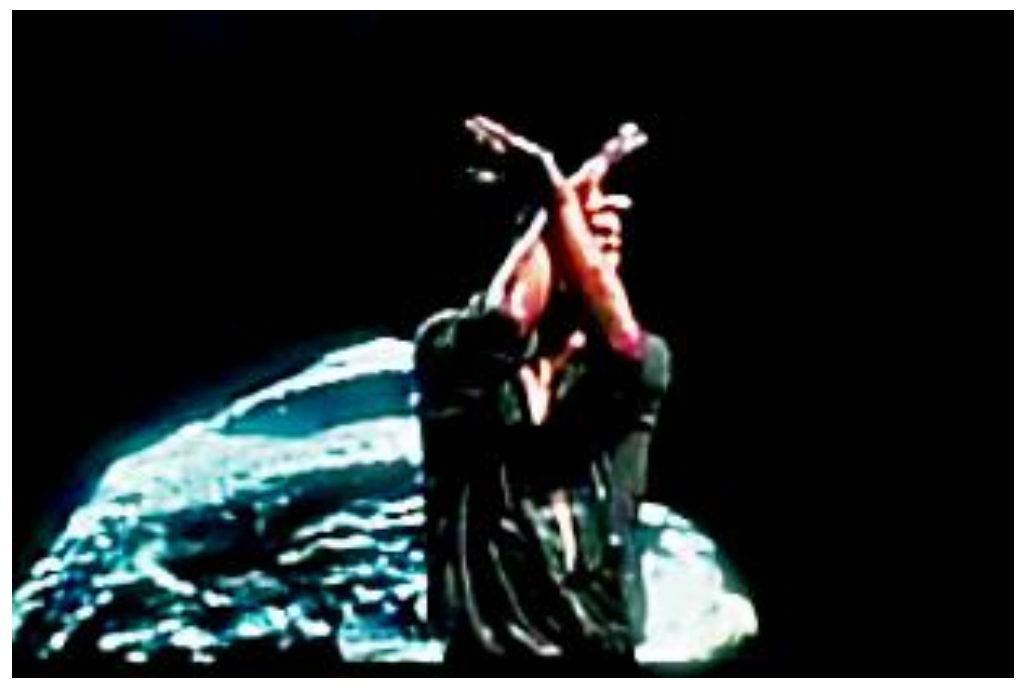

Figura 125:

"Braços de

Pássaro"

(frame do vídeo) 
Primeiro eu na frente deles os olhos fixos em uma imagem. Que eu não

encontro, que não sei qual é.
É a brincadeira com o procedimento de Adler
Instauração do ato de ver.

O foco está dividido com a atividade de calçar a sandália.
Eu era uma menina solitária, vagueando pelas ruas da Praia de Canasvieiras em Florianópolis. Pegava fruta no pé, roubava cana-deaçúcar. Uma vez eu desafiei o meu irmão para enfiar a cabeça dentro de um aro de madeira que tinha numa cadeira de balanço lá de casa. Ele enfiou e não conseguia mais tirar. (Junto ao murmúrio da voz) Uma vez eu cheguei em casa e minha mãe estava toda machucada. Ela disse que ladrão entrou e bateu nela. Eu cheguei a desconfiar que era mentira. Que meu pai é que tinha batido nela.

De repente vem... é claro que... com aquele braço e aquela boca... o assassino ( $\mathrm{eu}$ podia escolher): ia acabar com a vida dela, ia acabar com ela, ia querer acabar com ela, ia matar ela, ia calar a boca dela
Memória de infância propositadamente colocada no pré-jogo.
Memorizada instantes antes de entrar em cena, deixo escapar a fala.
Brincadeira da escolha da fala em cena.
"Ia querer acabar com a vida dela" é enunciada com intensidade, precedida de uma explosão junto a "É claro!" e a "braços de bateria", instalado de súbito: o movimento do bailarino batendo várias vezes na perna reaparece absorvido na situação ficcional.

A visualização do homem e o vagar na execução dos movimentos. Uma explosão de intensidade na hora do estapeamento. Corpo invadido pela incidência aparecendo outra dinâmica.

Em foco a imagem do hálito do homem. A incidência atravessa a área de vulnerabilidade onde é atualizado o movimento com excesso de velocidade.

Tabela 3: Material de Incidência e Impressão Digital 
Estava tudo escuro, ela não enxergava nada.

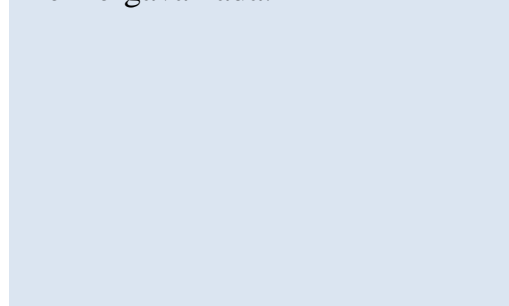

Ele disse que matou por ela.

Caminha de salto alto. Vai até a mala. Pega uma maça e come. Pensando: ele disse que matou por ela
Frase de Nelson Rodrigues que interrompe o movimento anterior, colocando um ponto nesta parte da cena (o próximo movimento será levantar-se da cadeira) e fazendo alusão ao que acabo de viver: a luta exasperada com o homem que estava querendo me tocar.

É uma fala interna onde posso apoiar o foco enquanto levanto e caminho. Na hora que se instala, substitui o registro anterior, criando um novo impulso.

Rubrica criada para o pré-jogo. A imagem do andar de uma bailarina de "Walzer", (Bausch) e momento de diálogo com o público. A bailarina morde a maçã e cospe.
Apoio a mão na bacia como faz uma bailarina da Pina Bausch.

\section{É boa a sensação de revelar o pensamento onde posso me apoiar. Faço com gosto.}

Usei isto.
Ele imobilizou a cabeça dela. Segura forte nos cabelos com a mão direita. Ela travou os dentes. E disse: - Ah é? Você quer? Então vem. E ela se entregou a ele sem nenhum frêmito. A mãe também se entregou. Mas ela sem nenhum frêmito. E com uma felicidade dramática ela pensou que tinha vingado a mãe
Situação ficcional extraída de Rodrigues; enquadramento da fala externa que o evoca e também imagens próprias (articuladas com a minha vida e que me mobilizam e implicam a opção pelo gesto de segurar firme a raiz dos cabelos).

O público não sabe o que estou associando: é material de incidência oculto. Mas ele também enquadra na medida em que a mimetização deste material implica a ordenação das bordas corporais.

Há um imaginário articulado em interpretação (quanto a ela dizer "sem nenhum frêmito") que serve como campo de extração. Meu olhar enquadra a cena; há a plasticidade do meu olhar formando como que um limite, situando o que produzo.
Pego com força nos meus cabelos e giro a cabeça par ao lado. Estou atrás do varal de bonecas e, dividindo o foco de atenção, tendo encontrar a fresta por onde posso aparecer para o espectador.

Tabela 4: Material de Incidência e Impressão Digital

9 http://www.youtube.com/watch?v=QrdwjIgakNo (último acesso em 29/05/2012). 
Dedico-me a um "vai e vem" entre a experimentação das variações destes movimentos (com falas internas que os transformam) e escrita (treino na imobilidade). Há repetição, variação, corte, reformulação, condensação, troca de lugar antes do préjogo ficar pronto. Alguns movimentos não entram. Nomeio-os, experimento variações com falas internas, mas não os incluo: é material "a parte", experimentado apenas no aquecimento, antes da improvisação diante do CEPECA. O que deixo de fora pode voltar em algum momento; subitamente, na área de vulnerabilidade, sem planejamento e sem ter passado pelo pré-jogo. O que o pré-jogo faz é abrir a perspectiva de encadear, definir locais de entrada; ou aparição de uma cadeia inteira (uma ordem já fixada) que carrega algo novo, preenchendo. O pré-jogo funciona como corte e condensa o que foi cortado (como na carta de Kusnet). Algumas observações:

$\checkmark$ Ao escrever "Movimentos rápidos das partes do corpo. 1212 2. Cotovelo direito. Seio e vagina” foi associado: “Meu Deus, ele está aqui!". O material suporta o imaginário da relação do eu com o outro; a plasticidade (imagens) desta relação faz incidência. O material não está no pré-jogo (encadeamento na horizontal), mas está presente no eixo vertical.

$\checkmark$ "Sua puta" foi cortado: "Pára, respira, caminha, para, olha, morde a maçã, tira da boca e Jorge: Sua puta! Você não viu que o assassino quer calar a boca da testemunha? Continua comendo a maçã. Pega na boca e joga fora: Puta, não viu?"

Os movimentos de Bausch foram extraídos de um vídeo (postado no youtube) do filme "Pina por Wim Wenders" espaço-temporal, contando com a ajuda de falas internas. Exemplos de nomeações:

$\checkmark$ "Com as duas mãos na coxa".

$\checkmark$ "Movimento dos gestos rápidos bem na frente do rosto".

$\checkmark$ "Braço longo e na cabeça" (com) "reunindo todas as minhas forças para me libertar dei um arranco, mas ele me prendeu de novo".

$\checkmark$ "Braços de bateria" (com) "porra" (e) "eu sentia a respiração forte"

$\checkmark$ "O bailarino de Pina Bausch" (com) "no escuro".

${ }^{10} \mathrm{http://www.youtube.com/watch?v=kV2mPO5Ckeg} \mathrm{último} \mathrm{acesso} \mathrm{em} \mathrm{28/05/2012.} \mathrm{Ainda} \mathrm{não} \mathrm{consegui}$ extrair imagens dos vídeos de Pina Bausch para colocar no relatório. 
$\checkmark$ "Braços de pássaro"

$\checkmark$ "Pega a respiração"

Experimentando o revezamento entre a escrita no papel e o corpo em cena, incluo, na escrita, o que a escuta do corpo associa.

$\checkmark$ "Pega a respiração" associa "Vou experimentando o gesto, uóu uóu, estranha, tão estranha, uóu, aquela espécie de luta, uóu, sem palavras". "Uóu” é um som que faz incidência e segue interrompendo a fala externa.

Continuo a escrever. São tentativas de composição:

$\checkmark$ Pára!! (ordem) Calma!! (ordem) Eu!! Lógico!! Eu!! Olhar de que ele pode estar por aí!!

$\checkmark$ Senta. A respiração. Joga tudo com a mão comprida. Limpa tudo. De salto alto. As duas mãos na cocha. Eu prometo que não conto nada pra ninguém. Se concentra. Aonde os olhos vão pousar? Levanta. Tava tudo escuro!!

$\checkmark$ Eu não enxergava nada, tava tudo escuro. Quando ele me mandou calar a boca matei a xarada, era Jorge!

$\checkmark$ Caminha, senta, arrumando o cabelo (de Pina) As duas mãos na coxa. Se concentra: aonde o olho vai pousar? Me deixa ir! Eu juro que não conto pra ninguém. Levanta, vai atrás da cadeira, bate.

$\checkmark$ Ela entra de salto, para, opa, respira. Entra de salto, para, opa, olha, morde, tira, cospe. Sua puta! É claro que o assassino ia calar a boca da testemunha. Morde, engole, cospe. Tudo escuro? Eu não enxergo nada! Morde, engole, cospe. Aos empurrões. Ia aos empurrões. Morde, engole, cospe. A cabeça? Imobilizou minha cabeça.

Até chegar a expressão que ficou no pré-jogo ("imobilizou minha cabeça") uma série de pequenas incidências foram acumuladas. Este processo de escrita é uma preparação. Os dois processos são preparatórios: a experimentação dos movimentos em cena e a nomeação na escrita. São duas experimentações. Três na verdade, pois a associação-livre durante o cotidiano implica uma experimentação até que a imagem cênica (o arranjo externo) seja visualizada. 
$\checkmark$ Morde, cospe, foge, os lábios, trava os lábios. Morde, cospe. Louca? Joga. Deu uma espécie de loucura nele? Morde, cospe, joga. Chega!

$\checkmark$ Caminhando em círculos: eu estava certa de que tinha chegado a minha vez. Presa nos seus braços ainda me debati. E esbofeteei-o. E por fim reunindo todas as minhas forças para me libertar dei um arranco. Mas ele rápido me prendeu. Como se quisesse me torturar. Muito rápido os movimentos das partes. 12 cotovelo direito seio e vagina 123 braço. Eu sentia a respiração forte. Sons? As batidas do coração. Estranha, tão estranha aquela espécie de luta sem palavras no escuro!

Momentos antes da apresentação no CEPECA:

O pré-jogo é memorizado pela repetição da escrita no dia anterior e no mesmo dia pela manhã. Vou para a cena experimentar variações do desenho corporal. Enquanto rememoro a imagem acústica do pré-jogo em escuta interna, vario os movimentos de Bausch (com a incidência da luz da projeção e dos objetos). Aparecem associações. A batida da mão na perna (com "braços de bateria") evoca "uma moça correndo e um homem quase a tocando". A situação ficcional articula outras incidências: as imagens pessoais. Perambulo pelo cenário, escrevendo. Eles entram. Experimento mais uma vez os impulsos sem o enquadre da partitura física (apenas a figura perambulando). Quando já estão sentados, emperro: um ponto da memória falha. É como se precisasse "viver para lembrar". Largo as folhas de papel e começo. Na interlocução com o CEPECA, temos a ideia de utilizar o "quem" escritora como articulador do contexto ficcional. Crio um prólogo com a ação de tentar escrever (o que a voz sonorizada dita) e não conseguir (porque a voz falha; some).

Apresentação no CEPECA:

A luz da projeção faz incidência; quase me cegando, entra em foco. No jogo, a regra: "não olhar diretamente para a luz". Mas não consigo. Quase consigo. Isto se torna um jogo: "olhar ou não olhar?" - e situa o foco. Por trás da luz, vejo o público nas bordas do campo de visão. 
No momento em que revelo as memórias junto à "regra de jogo" visualizar, divido o foco de atenção com a ação de colocar a sandália. A fala externa traz um enquadramento do som da voz e implica um tempo de enunciação. $\mathrm{O}$ foco de atenção nas memórias implica a absorção do desenho externo (que descansa, enquanto o foco está na escuta da fala, que evoca imagem). Mas tenho, também, os gestos de Bausch. Os dois arranjos são diferentes e se substituem no encadeamento cênico. A brincadeira de morder a maçã e cuspir se estabelece como um terceiro arranjo. Por fim, a música do Led Zeplin. Picho "Fuck me" na parede, finalizando com uma ação de levantar a saia e desfilar (imaginei a ação, mas não sabia se viria). Trata-se de uma pequena sucessão de arranjos - cada qual com o seu jogo de incidências e enquadramentos implicado. $\mathrm{Na}$ brincadeira de morder e cuspir a maçã (e prender a cabeça pela raiz dos cabelos como se Jorge os puxasse) escondo uma parte do corpo atrás do varal com bonecas penduradas. O foco vai para o enquadramento daquele vão (como foi visualizado no pré-jogo). Fico pensando (deixo ecoar): "ele disse que matou por ela". Construo o pensamento "da personagem" aqui. A incidência do material marca a "ação de pensar": há este lugar de sustentação de ação interna enquanto o foco se divide com os pedaços de maçã (que voam longe) e o barulho que a cusparada que faz. Uma imagem acústica que posso lançar mão, enquanto o enquadramento está em jogo: a plástica de um cotidiano "meio maluco", subvertido. Comer maçã atrás do varal traz plasticidade para a impressão digital naquele momento - e isto faz incidência. 


\section{CONCLUSÕES}

Creio que fazemos coisas com as palavras e, também,

que as palavras fazem coisas conosco

(Jorge Larrosa Bondía)

Em prática pedagógica venho propondo variações dos procedimentos criados. Por exemplo, com alunos de iniciação teatral, proponho descrições de corpo a partir da imagem de pessoas das suas vidas. As descrições são trocadas entre eles. Quando o ator se apropria da descrição de outro, coloca algo de si e vai além desta (tanto no momento da memorização quanto da improvisação) testemunhando-a como um dos materiais do arranjo. Antes da improvisação, passa-se pela redução do pré-jogo (descrição misturada à fala interna), transformando-o em quatro linhas. A orientação é focar em uma fala interna, curta e imperativa, para que eles não fiquem preocupados com os desenhos (e deixem que estes sejam atualizados na área de vulnerabilidade, enquanto o foco se divide com as impressões digitais descobertas no improviso).

A cada processo de criação que inicio com os atores, encontro novos caminhos de manejo da mesma estrutura e de reinvenção dos procedimentos. O diálogo com a cultura cênica a partir da oposição formalizada em pesquisa me entusiasma na medida em que junto, corto, invento, crio, monto resoluções diferentes em cada processo. Em "Casa" estive, durante três anos, sozinha em cena. Inventei a régua sonora (voz) com a qual estabeleço relação e tenho o espectador - que por duas vezes interpelo. Mas no trabalho com texto dramático (Tenesse Williams, Nelson Rodrigues, Beckett, Plínio Marcos, Sarah Kane, Naum Alves de Souza, Koltès, Jean Genet, Ionesco, Arrabal, Gianfrancesco Guarnieri, Leilah Assunção, etc) - em diversos workshops com atores percebi o quanto o "entre dois", a relação, é conduzida pelo enquadramento dramático oferecido pela fala externa, na medida em que o ator constrói um subtexto que implica ações (esta outra linha, que pode estranhar ou evocar diegese familiar, cuja identificação está em jogo). Mas que, no entanto, os mesmos textos resultam em resoluções cênicas bastante diferentes conforme os outros materiais que o ator maneja. Os mesmos textos são remontados em diferentes workshops. Conto com os improvisos deles com o préjogo quando estão sobre a incidência das palavras; e com as fissuras, na malha textual, onde se introduzem arranjos de anteparos, cuja ressonância produz cena. Trabalhamos 
com espaços diferentes: banheiro, arena, italiano, rua, saguão redondo de mármore onde ressona a voz, sala de aula de kung fu ou sala de aula com carteiras escolares, casa em ruínas com janelas grandes ou câmera de cinema - ou qualquer outro espaço que tenho para trabalhar. O espaço implica enquadramento em função do qual as reverberações dos outros materiais se acomodam e as relações evocadas pelo texto (e sustentadas por ações) se alteram. Conforme o ator, o que ele traz em seu repertório e é atualizado (na área de vulnerabilidade), o treinamento, as imagens em associação, o que constitui de analogias com a vida e a sua interpretação (que entra inevitavelmente em jogo como estímulo); visualmente o que o ator evoca em cena (cada corpo é diferente do outro), como maneja materiais externos de caracterização (se estes estranham ou não) - tudo isso altera radicalmente a visualidade da diegese.

Como diretora, corto, elejo, com eles, campos de extração, proponho trocas, dialogo para demandar-lhe associações pessoais; substituições para o engajamento em imagens internas e sustentações das pulsões para as ações, enquanto descobrimos o enquadramento plástico corporal que vai implicar a poética daquela figura em especial. Falas internas diferentes cortam (dividem) o texto do autor e provocam a alternância das ações - enquanto manejamos materiais de enquadramento como objeto, movimentação, espaço, desenho do corpo. Às vezes projeção e sonoridades diferentes; às vezes o vídeo; às vezes a relação diegética rompida para a abordagem direta do espectador ou uma canção (que denuncia a construção, mas tudo isto com certa delicadeza).

A visualidade das ações não é algo que se constrói das palavras; não se trata de representar o texto ou a fala, pois esta é opaca. Trata-se de ver uma coisa ou outra. E o que se vê muda. Constrói-se uma visualidade da construção cênica; e a visualidade da relação inscrita na diegese evocada, criada na hora (e que muda) - não representada. A fala interna, a apropriação do próprio contexto (construção da fala em nome próprio), o fato de fazer reverberar uma imagem acústica, evoca a visualidade de um pensamento enigmático: algo "lá dentro" que se mexe. Nestes ateliês estou fora e provoco-os. Mas exploramos juntos e compartilhamos a potência de uma associação ou quando partituras - de formas extraídas das artes plásticas, teatro performativo e atividades de puxar, empurrar e lançar (aos moldes barbianos) - são deformadas, o suficiente para vermos os seus resíduos aconchegando-se junto às ações evocadas no jogo.

Os atores trazem de si uma visualidade cotidiana, jeito particular de apropriarse das palavras. O exercício com a memorização através da escrita (que permite que uma cadeia de impulsos entre na área de vulnerabilidade da mesma maneira que as 
figuras das artes plásticas entraram sem querer na cena de "Casa" quando eu preciso preencher o enquadramento espaço-temporal cênico), não anula a importância dos treinamentos e do uso rigoroso de anteparos para a plasticidade das vozes e do corpo. Os treinamentos codificados, formalizados e transmitidos na cultura teatral, que atores em formação têm acesso, principalmente, em aulas de corpo e voz, trazem perspectivas de atualização na área de vulnerabilidade de algo codificado como cênico; pensado como poética. Muitas vezes a partitura é constituída e, depois, precisa ser desmanchada, com um anteparo que altera todo o arranjo (desarranja) e constitui outras cadeias. Muitas vezes um material imperativo do contexto do ator (como "não sei por que não estou conseguindo desta vez") é o que falta para constituir uma visualidade diferente para a ação da personagem (algo que ainda não tínhamos visto).

A constituição do trabalho com no ateliê do corpo dramático se faz tal como no espetáculo performativo: com fragmentos e a tessitura da ação vivida no aqui e agora, na medida em que o ator é enquadrado de maneira específica. $\mathrm{O}$ enquadramento muda, mas não a estrutura do trabalho. Pedaços que não seguem a inteireza de uma interpretação a anteriori são associados e se encontram; eterno ver o que não tínhamos visto durante a escuta da escrita cênica. Não no papel. Cênica. A escrita cênica não é o significante que se escuta - como vimos no caso da figura da avó cega de "Casa", a partir da qual espectadores do CEPECA articularam interpretações bastante diferentes (e em outros momentos me deparei com leituras inusitadas). A letra (cênica) se lê na medida em que se escuta o significante. Mas um enquadramento (ações) é constituído e enxergado por várias pessoas ao mesmo tempo, mesmo que associem outras coisas. É importante, para o trabalho com o texto dramático a constituição deste enquadramento. A plasticidade cênica que estranha é algo que se joga, choca, combina ou dissona com o dramático.

Não assumo o discurso pós-dramático como meu. Não acredito na justaposição do texto em cena sem articulação com o corpo (como faz Bob Wilson quando propõe duas camadas diferentes). O corpo promove uma leitura - outra cadeia - diferente das palavras, que se constituem como enquadramento específico. Temos enquadramentos diferentes (as ações físicas e as palavras externas), que se opõem muitas vezes. Mas se articulam, evocando um terceiro: o diegético. É uma especificidade do enquadramento dramático - que não é linear; que se rompe, pois novos olhares são convocados. Tratase de um complexo jogo, onde se dialoga com a cultura e seus saberes constituídos (e se marca uma posição). Posso duplicar personagens, deslocar falas de um para o outro, 
alterar a ordem das cenas. Os atores desenham com giz o cenário onde se passa a ação; iluminam com lanternas e lampiões a cena do outro; escrevem enquanto a sua hora de entrar não chega. Evidencia-se a construção; eixo extraficcional. Mas, em jogo com a visualidade da plasticidade cênica, estão as ações de uma diegese que aparece, pode ser vista no enquadramento da palavra que a filtra, bordeia, contorna, como se fosse uma janela com grades - para se assistir a um mundo visual, esfacelado, que, às vezes, se densifica (um jogo entre construção e destruição da sua forma).

Foi no último ano da pesquisa com "Casa" que encontrei as proposições sobre a figuração do objeto a na arte (Dunker, 2010) - de maneira que, retroativamente, olho minha produção cênica e penso se não seria como um excesso que aponta para o vazio (para este lugar de não inscrição, onde o desejo se situa, com o sujeito, no lugar elidido do quadro, protegido pelo anteparo e, ao mesmo tempo, efeito da poética que convoca o olhar). No entanto, o mais importante, é o manejo de uma estrutura onde está implicada uma autodireção: se autoprovocar com anteparos. Mesmo quando o trabalho conta com o diretor (e por diversas vezes tenho ocupado esta função), o ator é parceiro da direção de si. O ator é alguém que provoca o seu próprio corpo para constituir resultantes investigando o caminho do manejo das funções que evidenciamos: enquadramento, incidência e vulnerabilidade. A diferença dos ateliês que exercitamos só comprova a tese de uma estrutura. Se, em diferentes ateliês, manejamos as mesmas funções é porque são estruturais. Falo aqui do dramático por ser meu repertório de vida, mas acredito que poderia estender estas três funções (e a ideia de seu manejo) para outras modalidades, que estão no repertório de muitos que lerão este trabalho.

Esta pesquisa não se encarregou de constituir um ateliê-modelo, mas de usá-lo como método para a extração de uma estrutura que pode instrumentalizar outros ateliês. Não chegaria a ela se não fosse esta prática no CEPECA. Foram os impasses da criação que me levaram a formaliza-la. Há o reconhecimento desta instância que faz incidência sem estar inscrita na realidade objetiva, sendo texto do processo (de um tempo passado que reverbera). Há reconhecimento de uma série de tensões: a incidência do material oculto e o enquadramento que tende a destruir ou construir; a indeterminação e o foco (que recorta materiais); a rigidez do encadeamento que se opõe ao material que, fora da cadeia, se intromete; a partitura do enquadramento, que se opõe à liberdade de quebrá-lo com novas incidências; a escuta do corpo (evocando livre-associação) e o que já está determinado, escrito; os diferentes materiais que dividem o foco. Testemunha-se um 
processo de livre-associação e incidência também fora de cena - de maneira a fazer encontrar materiais, cortá-los e desdobrá-los para criar novas soluções.

A elaboração do movimento como modalidade de anteparo foi decisiva, pois o movimento não é uma impressão digital, mas material a ser modificado, produzindo a impressão digital em arranjo com outros: o mesmo movimento, com diferentes músicas (ou falas internas), gera outras resultantes. As ações físicas também são anteparos de enquadramento, pois podem ser repetidas. A impressão digital é aquela que não se repete, sempre instantânea. A partitura física (que se pode repetir) é anteparo, um material de enquadramento em jogo, a transformar-se com outros para impressões digitais serem inscritas em cena.

A plasticidade prevalece como um valor: a propriedade de transformação da visualidade. O movimento tem uma plasticidade (pois pode se transformar), assim como a ficção, o cotidiano, o olhar. A proposição "enquadramento é o que organiza no tempo e espaço" define a diferença em relação à incidência. Diferença que não é pautada pela oposição entre dentro e fora. Um material externo pode fazer incidência; um material interno pode enquadrar (como, por exemplo, uma regra de jogo que organiza tempo ou espaço); um material pode fazer incidência enquanto enquadra.

Testemunha-se a importância da área de vulnerabilidade, porque um material de incidência (apenas) ou de enquadramento (que incide) pode ali atualizar seus efeitos - e a perspectiva do treinamento (pois este implica um manejo de atualizações). Trata-se de se aproveitar de um tecido vivo, que pode ser marcado, transpassado por incidências. A escrita repetitiva de um pré-jogo se apresenta como uma modalidade de treinamento; estratégia de manejo da área de vulnerabilidade em processos de criação; introdução de reverberações encadeadas em certa ordem ainda sem o enquadramento plástico-corporal para que este seja descoberto no jogo com o outro, relação e associações novas. Uma prática da improvisação também se configura como um treinamento. $\mathrm{O}$ ator deixa que a livre-associação faça incidência. Ele se acostuma a habitar este arranjo, repetindo-o. Repetição que envolve amor e relações de transferência.

A inscrição no discurso que não é meu, mas onde se encontrou lugar, fez laço. Que rede de palavras o amor de se inscrever em Laban maneja? E em Chekhov? Estes são mestres que romperam com discursos que os antecederam e criaram palavras em rede para apanhar o ator, como em uma teia. Resta criar esta que é cênica - e depende da autonomia do ator para enlaçar os seus materiais. Porque é a memória do seu corpo que vai estar lá, com as suas reverberações. Entrelaçar-se ao discurso do outro, mas 
colocar, de si, a reinvenção, significa, muitas vezes, encarar a indeterminação. Isto é pesquisa. O que é mais interessante é quando o ator começa a constituir os materiais, a manejar o próprio jogo - encontrando um jeito de reinventar a sua prática, conforme novo processo, com novos laços, articulando a estrutura coletiva. Logo se evidencia que é preciso criar os arranjos com a sua linguagem, jeito, relações, pensamento. Trata-se de diálogo - porque é destas relações que algo escapa e é novo. É no que desliza (e não no que se circunscreve nos limites imaginários de um eu) que se cria e fixa. Existe um campo estreito e fértil no que não é de ninguém, mas circula: a linguagem. O que me fez pensar: não é possível ser neutro. Nossa ética seria balizada pela perspectiva de levar algo sem paixão?

Testemunha-se que a historicização é importante para a entrega em uma prática passional por estrutura. De maneira a eleger oposições paradigmáticas - na medida em que os arranjos podem ser desmontados e materiais extraídos. Artaud diz: "transitar pelo estado de desorganização e saber como sair, buscando o equilíbrio entre o dionisíaco e o apolíneo". Não haveria, aí, um testemunho da vulnerabilidade em jogo com um enquadramento? Mas, para que este se configure, organizando tempo e espaço, é preciso desorganizá-lo? Quando Bausch coloca uma questão para o ator responder com a sua cena, não estará, na área de vulnerabilidade, a reverberação dos movimentos sendo atualizada enquanto a pergunta feita por Bausch faz incidência? São questões que posso me colocar depois desta pesquisa. É uma maneira de pensar a prática que pode orientar um estudo da estrutura para fundamentar novas experimentações.

A impressão digital é a resultante de um arranjo das incidências de materiais, jogo de enquadramentos e do que o corpo atualiza na área de vulnerabilidade. Mas tratase de um arranjo que necessita de significantes específicos - e um diálogo com a cultura cênica. Haverá sempre materiais de incidência e de enquadramento; materiais cuja incidência é atualizada naquela área de vulnerabilidade que implica a memória corporal. Nesta estrutura, da nossa prática, cabe uma variedade infinita de ateliês. O que o anteparo, como instancia estruturadora (no vetor com a impressão digital), permite entrever é a determinação da linguagem - que às vezes me falta. A inscrição do ator na poética cênica depende de um discurso onde se encontra "lugar para habitar". Discurso que é laço social (diz Lacan) e se a cena é um discurso (cênico) o ator também a habita e faz laço. 


\section{REFERÊNCIAS BIBLIOGRÁFICAS:}

\subsection{Livros:}

ABBAGMANO, Nicola. Dicionário de Filosofia. São Paulo: Martins Fontes, 2007.

ABENSOUR, Gérard. Vsevold Meierhold ou A Invenção da Encenação. São Paulo: Perspectiva, 2011.

ABIRACHED, Robert. L'Acteur et Son Jeu. In COUTY, Daniel \& REY, Alan (org.) Le tréâtre. Paris: Brodas, 1980. Tradução não publicada de José Ronaldo FALEIRO. 1994.

ADLER, Stella. Técnica da Representação Teatral. Rio de Janeiro: Civilização Brasileira, 2010.

APPIA, A. A Obra de Arte Viva. Notas e trad. Redondo Júnior, Lisboa, Arcádia, S/d.

APPIGNANESI, R \& ZÁRATE, O. Freud para Principiantes. Buenos Aires, Era Naciente, 2010.

ARISTÓTELES. Poética. Trad. Eudoro de Souza. Lisboa: Guimarães, s. d. Coleção Textos Universitários.

ARTAUD, Antonin. O Teatro e Seu Duplo. São Paulo: Hucitec, 1994. . Eu, Antonin Artaud. São Paulo: Assírio Alvim, 2007. . Linguagem e Vida. São Paulo: Perspectiva, 2008.

ASLAN, Odette. O Ator no Século XX. São Paulo: Perspectiva, 1994.

AUBERT, J et alii. Lacan: O Escrito, A Imagem. Belo Horizonte, Autêntica Ed, 2009. AUMONT, Jacques.

AUMONT, Jacques \& MICHEL, Marie. Dicionário teórico e critico de cinema.

Campinas: Ed. Papirus, 2003.

BADIOU, Alain. On Beckett. Manchester, Clinamen Press Limited, 2003.

BARBA, Eugenio. Além das Ilhas Flutuantes. São Paulo: Hucitec, 1991.

A Canoa de Papel: Tratado de Antropologia Teatral. São Paulo: Hucitec, 1994. Mulino, 1993.

La Canoa di Carta: Trattato di Antropologia Teatrale. Bologna: Il Terra de Cinzas e Diamantes: Minha Aprendizagem na Polônia. São Paulo: Perspectiva, 2007. 
BARBA, Eugenio \& SAVARESE, Nicola. A Arte Secreta do Ator. São Paulo: Hucitec, 1995

BARTHES, Roland. Novos Ensaios Críticos. São Paulo, Cultrix, 1974. O Grau Zero da Escritura. São Paulo, Cultrix, 1971. O Grão da Voz. São Paulo, Martins Fontes, 2004.

. Elementos de Semiologia. Lisboa, Edições 70, 2007. Lição. Lisboa, Edições 70, 2007.

BAUMGARTEL, Stephan. Em busca de uma teatralidade textual performativa além da representação dramática: reflexões sobre a verdade formal na dramaturgia contemporânea. In: Sobre Performatividade. Florianópolis: Ed. Letras Contemporâneas, 2009, p. 127-179.

BECKETT, Samuel. O Inominável. Tradução de Maria Jorge Vilar de Figueiredo.

Lisboa: Assírio \& Alvim, 2002.

BENJAMIN, Walter. O Narrador: considerações sobre a obra de Nikolai Leskov. In:

Magia e técnica, arte e política: ensaios sobre literatura e história da cultura. São Paulo Brasiliense, 1994, p. 197-221.

BERTHOLD, M. História mundial do teatro. São Paulo, Ed. Perspectiva, 2000.

BONFITTO, Matteo. O Ator-compositor: As Ações como Eixo: de Stanislavski a Barba. São Paulo, Perspectiva, 2007.

BORNHEIM, Gerd. Brecht: a estética do teatro. São Paulo: Graal, 1992.

BRECHT, Bertold. Estudos Sobre Teatro. Lisboa: Portugalia, 19-? . Estudos Sobre Teatro. Ed. Nova Fronteira: Rio de Janeiro, 1978.

2002. . Diário de Trabalho: Volume I (1938 - 1941). Rio de Janeiro: Rocco,

BROOK, Peter. A Porta Aberta: Reflexões Sobre a Interpretação e o Teatro. Trad.: Antonio Mercado - $2^{\text {a }}$ ed. - Rio de Janeiro: Civilização Brasileira, 2000. . O Teatro e seu Espaço. Petrópolis: Ed Vozes, 1970.

. Prefácio a OIDA, Yoshi. Um ator errante. São Paulo: Beca Produções Culturais, 1999.

BORNHEIM, Gerd. O Sentido e a Máscara. São Paulo: Perspectiva, 1969.

BURNIER, Luiz Otávio. A Arte do Ator - Da Técnica à Representação. Campinas: Ed. Unicamp, 2001.

BUSNACH, William (1884). Trois pièces. Paris, Charpentier.

CABAS, A. G. Curso e discurso na obra de Jacques Lacan. São Paulo: Centauro Ed., 2005.

CAMUS, Albert. O mito de Sísifo. Tradução de Mauro Gama. Rio de Janeiro: Editora 
Guanabara, 1989.

CÂNDIDO, Antônio. A Personagem de Ficção. São Paulo: Perspectiva, 1992.

CARLSON, Marvin. Teorias do Teatro. São Paulo: Unesp,1997.

CARREIRA, A \& NASPOLINI, M (org.). Meyerhold: Experimentalismo e Vanguarda. Rio de Janeiro. Ed. E-papers, 2007.

CAVALIER, R \& LURIO E. Platón para Principiantes. Buenos Aires: Era Nasciente, 2005

CHAVES, Yedda Carvalho. A biomecânica como princípio constitutivo da arte do ator. Dissertação de mestrado. São Paulo: CAC-ECA-USP, 2001.

CHEKHOV, Michael. Para o Ator. São Paulo: Martins Fontes, 2003.

CHNAIDERMAN, Miriam. O Hiato Convexo: Literatura e Psicanálise. São Paulo: Brasiliense, 1989.

COELHO, Teixeira. O que é Ação Cultural. São Paulo: Brasiliense, 2006. Em Cena, o Sentido. São Paulo: Duas Cidades, 1980.

COHEN, Renato. Performance como Linguagem. São Paulo: Perspectiva, 2002 Work in progress na Cena Contemporânea: Criação, Encenação e Recepção. São Paulo: Perspectiva, 1997

COPEAU, Jacques "A interpretações das obras dramáticas do passado" In: COPEAU, Jacques. Registrei, II, III, IV. Paris, Gallimard, 1974-84.

CORREIA, T. Real, Simbólico e Imaginário em Lacan. Ciências Humanas em Revista. São Luis, v.3, número especial, junho de 2005.

COURTNEY, Richard. Jogo, Teatro e Pensamento. São Paulo: Perspectiva, 2003.

COUTINHO, M. A. \& FERREIRA, N. P. Lacan: O Grande Freudiano. Rio de Janeiro, Zahar, 2009

CRAIG, Gordon. Da Arte do Teatro. Lisboa: Arcádia, s/d.

DESGRANGES, F. Pedagogia do Espectador. São Paulo, Ed. Hucitec, 2003.

DORT, Bernard. O Teatro e sua Realidade. Trad. Fernando Peixoto. São Paulo: Perspectiva, 1977.

DOSSE, François. História do Estruturalismo. Volume I. Bauru, SP: Edusc, 2007.

DUNKER, Christian. Estrutura e constituição da clínica psicanalítica: Uma arqueologia das práticas de cura, psicoterapia e tratamento. São Paulo, Annablume, 2011.

. A Imagem entre o Olho e o Olhar. In: Sobre Arte e Psicanálise. São Paulo, Ed. Escuta, 2006, v.1, p 14-29.

ECO, Umberto. A Estrutura Ausente. São Paulo, Perspectiva, 1976. 
Lector in Fábula. São Paulo, Perspectiva, 2002.

ESSLIN, Martin. O teatro do absurdo. Tradução de Bárbara Heliodora. Rio de Janeiro: Zahar Editores, 1968.

FÉRAL, Josette. Os Camiños do Actor. Editorial Galaxia, 2004.

Teatro, Teoria y Práctica, Más Allá de las Fronteiras. Buenos Aires: Galerna, 2004.

FERNANDES, Ciane. Pina Bausch e o Wuppertal Dança-Teatro: Repetição e Transformação. São Paulo: Annablume, 2007.

FERNANDES, Sílvia e GUINSBURG, Jacó (org.). O pós-dramático: um conceito operativo? São Paulo: Perspectiva, 2010.

FERNANDES, S. Teatralidades Contemporâneas. São Paulo: Ed. Perspectiva, 2010.

FERRACINI, Renato. A Arte de não Interpretar como Poesia Corpórea do Ator. Campinhas: Unicamp, 2003.

FREUD, Sigmund. Escritos Sobre a Psicologia do Inconsciente. Volume I. Rio de Janeiro: Imago, 2004.

A interpretação dos sonhos. Rio de Janeiro: Imago, 2001.

FOUCAULT, Michel. O Que é um Autor, Lisboa: Vega, 2000.

GALIZIA, L. R. Os processos criativos de Bob Wilson. São Paulo: Ed. Perspectiva, 2005 .

GARCIA-ROZA, L. Freud e o Inconsciente. Rio de Janeiro: Zahar Ed, 1999.

GLUSBERG, Jorge. A Arte da Performance. São Paulo: Perspectiva, 2007.

GORDON, W.T \& LUBELL, A. Ferdinand de Saussure para Principiantes. Buenos Aires: Era Naciente, 2010.

GRIGOLO, Gláucia. O Paradoxo do Ator-Marionete: Diálogos com a Prática Contemporânea. Florianópolis: UDESC, 2005.

GuimarÃeS, D. M. Voz na Luz: Psicanálise e Cinema. Rio de Janeiro: Garamond, 2004.

GUINSBURG, J. Stanisláviski, Meierhold e Cia. São Paulo, Ed. Perspectiva, 2001.

GROTOWSKI, Jerzy. Em Busca de um Teatro Pobre. Rio de Janeiro: Civilização Brasileira, 1987.

Teatro Laboratório. México: Siglo XXI, 1980.

O Teatro Laboratório de Jerzy Grotowski, 1959-1969. São Paulo, Ed. Perspectiva, 2010.

GUINSBURG, Jacó. Stanislavski, Meyerhold \& Cia. São Paulo: Perspectiva, 2001. 
Stanislavski e o Teatro de Arte de Moscou. São Paulo: Perspectiva, 1985.

HAGEN, Uta. Técnica para o Ator: A Arte da Interpretação Ética. São Paulo, Ed. Martins Fontes, 2007.

HOLANDA, Buarque. Novo Dicionário da Língua Portuguesa. Rio de Janeiro: Nova Fronteira, 1986.

IANNINI, G. Estilo e Verdade em Jacques Lacan. Belo Horizonte: Autêntica, 2012.

IONESCO, Eugène. Notes and Counter Notes, tradução inglesa de Donald Watson, New York, 1964

."La tragédie du langage". In: Notes et contre-notes. Paris: Gallimard, Coleção Folio, 2006.

JAKOBSON, Roman. Lingüística. Poética. Cinema. São Paulo: Perspectiva, 2004. Lingüística e Comunicação. São Paulo: Cultrix, 19-?

JANUZELLI, Antonio. A Apredizagem do Ator. São Paulo: Ática, 1986.

JIMENEZ, Sergio. El Evangelio de Stanislavski Segun sus Apostoles. México: Gaceta, 1990.

JOUVET, Louis. Témoignages sur le théâtre. Paris: Flammarion, 1952.

KANTOR, Tadeusz. O Teatro da Morte. São Paulo: Ed. Perspectiva, 2008

KEHL, Maria Rita. Sobre Ética e Psicanálise. São Paulo: Cia das Letras, 2009.

KNÉBEL, María. La Poética de la Pedagogía Teatral. México: Siglo XXI, 2002.

. El Último Stanislavski. Madrid, Ed. Fundamentos: 2005.

KOUDELA, Ingrid. Jogos Teatrais. São Paulo: Ed. Perspectiva, 1991.

. Brecht, Um Jogo de Aprendizagem. São Paulo: Ed. Perspectiva,

1991.

. Texto e Jogo. São Paulo: Perspectiva, 1996.

. Brecht na Pós-modernidade. São Paulo: Perspectiva, 1991.

. Um Vôo Brechtiano. São Paulo: Perspectiva, 1991.

KUSNET, Eugenio. Ator e Método. São Paulo: Hucitec, 1992.

KRISTEVA, Julia. História da Linguagem. Lisboa: Edições 70, 2007.

LACAN, Jacques. O Seminário. Livro 1: Os Escritos Técnicos de Freud. Rio de Janeiro: Jorge Zahar, 19-?

.O Seminário. Livro 2: O Eu na Teoria de Freud e na Técnica da Psicanálise. Rio de Janeiro: Jorge Zahar, 1983. 
.O Seminário. Livro 3: As Psicoses. Rio de Janeiro: Jorge Zahar, 2008.

.O Seminário. Livro 4: A Relação de Objeto. Rio de Janeiro: Jorge Zahar, 1995.

.O Seminário. Livro 11: Os Quatro Conceitos Fundamentais da Psicanálise. Rio de Janeiro, Jorge Zahar, 1983.

O Seminário. Livro 12: Problemas Cruciais para a Psicanálise. Publicação não comercial exclusiva para os membros do Centro de Estudos Freudianos do Recife, 2006.

. O Seminário. Livro 16: De um Outro ao outro. Rio de Janeiro, Jorge Zahar Ed, 2008.

O Seminário. Livro 17: O Avesso da Psicanálise. Rio de Janeiro, Jorge Zahar Ed, 1992.

O Seminário. Livro 18: De um discurso que não fosse semblante. Rio de Janeiro, Jorge Zahar Ed., 2009.

O Seminário. Livro 20: Mais, Ainda. Rio de Janeiro, Jorge Zahar Ed., 1996.

2007.

O Seminário. Livro 23: O Sinthoma. Rio de Janeiro, Jorge Zahar Ed.,

A instância da letra no inconsciente ou a razão desde Freud. In: Escritos. Rios de Janeiro: Jorge Zahar Ed, 1998.

. Função e campo da fala e da linguagem. In: Escritos. Rio de Janeiro, Jorge Zahar Ed., 1998.

Subversão do Sujeito e Dialética do Desejo. In: LACAN, J. Escritos. Rio de Janeiro: Jorge Zaar Ed, 1998.

. Escritos. Rio de Janeiro, Jorge Zahar Ed., 1998.

. Outros escritos. Rio de Janeiro, Jorge Zahar Ed., 2003.

LAPLANCHE e PONTALIS. Vocabulário da Psicanálise. São Paulo: Martins Fontes, 2004.

LEADER, D \& GROVES, J. Lacan para Principiantes. Buenos Aires, Era Naciente, 2010

LECOQ, Jacques. El Cuerpo Poético: Uma enseñanza sobre la creación teatral. Santiago Ed. Cuarto Próprio, 2001.

LEHMANN, Hans-Thies. O teatro pós-dramático. São Paulo, Cosac Naify, 2007.

LEITE, N. V. A. (org.) Corpolinguagem: gestos e afetos. Campinas: Mercado de Letras, 2003. 
(org.) Corpolinguagem: a estética do desejo. Campinas, Mercado de Letras, 2005.

LEITE, N.V.A; AIRES, S \& VERAS, V. (orgs.) Linguagem e Gozo. Campinas: Mercado de Letras, 2007

Leite, N. V. A. \& Milán-RAMOs, J.G. (orgs.) EntreAto: O Poético e o Analítico. Campinas, Mercado de Letras, 2011.

LEMAY, E; PITTS, J.A. \& GORDON, P. Heidegger para Principiantes. Buenos Aires, Era Naciente, 2010.

LÉVI-STRAUSS, Claude. As Estruturas Elementares do Parentesco. Petrópolis: Vozes, 2008.

LISPECTOR, Clarice. A Paixão Segundo G.H. Rio de Janeiro, Ed. Rocco, 1968.

LOTMAN, Iuri. A Estrutura do Texto Artístico. Lisboa: Estampa, 1978.

MARTINS, Marcos Bulhões. Encenação em Jogo. São Paulo, Hucitec, 2004.

MEICHES, Mauro e FERNANDES, Silvia. Sobre o Trabalho do Ator. São Paulo: Perspectiva.

MEISNER, Sanford. On Acting. New York: Random House. Postlewait, Thomas, 1998.

MERLEAU-PONTY, M. Fenomenologia da Percepção. São Paulo: Martins Fontes, 2006.

MEYERHOLD, Vsevolod. Textos Teóricos. Madri: ADEE, 1992.

MILÁN-RAMOS J. G. \& LEITE, N. V. A. (orgs). Terra-mar: litorais em psicanálise - escrita, política, cinema, educação. Campinas, Mercado de Letras: 2010.

MILLER, Jacques-Alan. Lacan Elucidado: Palestras no Brasil. Rio de Janeiro, Zahar, 1997.

MIRALLES, Alberto. Novos rumos de teatro. Rio de Janeiro: Salvat Editora, 1979.

MOSTAÇO, E et alii. Sobre Performatividade. Florianópolis, Ed. Letras

Contemporâneas, 2009.

MÜLLER, Heiner. O Espanto no Teatro. São Paulo: Perspectiva, 2003.

NACACHE, Jacqueline. El actor de cine. Barcelona, Paidós, 2006.

OIDA, Y \& MARSCHALL, L. O Ator Invisível. São Paulo: Via Lettera, 2007.

OIDA, Yoshi. Um ator errante. São Paulo, Beca Produções Culturais, 1999.

PAVIS, Patrice. Dicionário de Teatro. São Paulo, Perspectiva, 1999.

O Teatro no Cruzamento de Culturas. São Paulo: Ed. Perspectiva, 2008.

A Análise dos Espetáculos. São Paulo: Perspectiva, 2003.

A Encenação Contemporânea: Origens, Tendências, Perspectivas. 
São Paulo: Perspectiva, 2010.

PEIXOTO, Fernando. O ator e a verdade cênica ou estar ardendo, para inflamar. In: Kusnet, Eugênio. Ator e método. São Paulo: Ed. Hucitec, 1992.

PICCON-VALlin, B. A Cena em Ensaios. São Paulo, Ed. Perspectiva, 2008.

PISCATOR, Erwin. Teatro Político. Rio de Janeiro, Ed. Civilização Brasileira, 1986.

PRADO, Décio de Almeida. O teatro brasileiro moderno. São Paulo: Ed. Perpectiva, 1996.

PUPO, Maria Lúcia. Entre o Mediterrâneo e o Atlântico: Uma Aventura Teatral. São Paulo: Perspectiva, 2005.

QUINET, Antonio. A Lição de Charcot. Rio de Janeiro: Jorge Zahar Ed., 2005. Um olhar a mais: ver e ser visto na psicanálise. Rio de Janeiro: Jorge Zaar Ed., 2004.

RAMOS, Graciliano. Linhas Tortas. Rio de Janeiro, Ed. Record, 2005.

RANCIÈRE, Jacques. O Inconsciente Estético. São Paulo, Ed. 34, 2009.

REgnaUlt, François. Em Torno do Vazio: A Arte à Luz da Psicanálise. Rio de Janeiro, Contra Capa, 2001.

RICHARDS, Thomas. Trabalhar com Grotowski sobre as ações físicas. São Paulo: Perspectiva, 2012.

RIVERA, T. Cinema, Imagem e Psicanálise. Rio de Janeiro, Jorge Zahar Ed., 2008.

RIVERA, T \& SAFATLE, V. Sobre Arte e Psicanálise. São Paulo: Escuta, 2006.

RODRIGUES, Nelson. Minha Vida: Romance Autobiográfico de Suzana Flag. São Paulo: Cia das Letras, 2003.

RÖHL, Ruth. O Teatro de Heiner Müller: Modernidade e Pós-Modernidade. São Paulo: Perspectiva, 1997.

ROUBINE, Jean-Jacques. A Linguagem da Encenação Teatral. Rio de Janeiro, Jorge Zaar, 1998.

A Arte do Ator. Rio de Janeiro: Jorge Zahar, 2002.

Introdução às grandes teorias do teatro. Rio de Janeiro: Jorge Zahar, 2003

RYNGAERT, Jean-Pierre. Introdução `a Análise do Teatro. São Paulo: Martins Fontes, 1991

. Ler o Teatro Contemporâneo. São Paulo: Martins Fontes, 1998.

. Jogar, Representar. São Paulo: Cosac Naify, 2009.

. Nouveaux Territoires du Dialogue. Arles: Actes Sud, 2005. 
RYNGAERT, Jean-Pierre \& SERMON, Julie. Le Personnage Théâtral Contemporain: Décomposition, Recomposition. Montreuil-sous-Bois: Éditions Théatrales, 2006.

RUFFINI, Franco. Stanislavskij: Dal lavoro dell'attore al lavoro su di sé. Roma:

GLF Editori Laterza, 2007.

SACKS, Oliver. O Homem que confundiu sua mulher com um chapéu. São Paulo:

Ed. Cia das Letras, 1992.

SAFATLE, Vladimir (org). Um Limite Tenso: Lacan entre a Filosofia e a Psicanálise. São Paulo: Ed. UNESP, 2010.

SAFATLE, Vladimir. A Paixão do Negativo: Lacan e a Dialética. São Paulo: Ed. UNESP, 2006.

Lacan. São Paulo, Publifolha, 2009.

SARRAZAC, Jean-Pierre. O Futuro do Drama. Porto: Campo das Letras, 2002.

SARRAZAC, Jean-pierre (org.). Léxico do drama moderno e contemporâneo. Trad. André Telles. São Paulo: Cosac Naify, 2012.

SAUSURRE, Ferdinand. Curso de Lingüística Geral. São Paulo: Cultrix, 2006.

SLOWIAK, J \& CUESTA, J. Jerzy Grotowski. São Paulo, Realizações Ed, 2013

SOURIAU, Etienne. As Duzentas Mil Situações Dramáticas. São Paulo, Ática, 1993.

SPOLIN, Viola. Improvisação para o Teatro. São Paulo: Perspectiva, 1992.

. O Jogo Teatral no Livro do Diretor. São Paulo: Perspectiva, 1999.

. O jogo teatral no livro do diretor. São Paulo, Perspectiva, 2004.

. Jogos Teatrais na Sala de Aula: o Livro do Professor. São Paulo: Perspectiva, 2007.

2000 .

. Jogos Teatrais: O Fichário de Viola Spolin. São Paulo: Perspectiva,

SILVA, Armando Sérgio. Oficina: do Teatro ao Te-ato. São Paulo: Perspectiva, 1981

. Interpretação: uma oficina da essência. In: SILVA, Armando Sérgio (org.)

CEPECA: uma oficina de pesquisAtores. São Paulo, Associação dos Amigos da Praça, 2010.

SOLER, Colette. A Psicanálise na Civilização. Rio de Janeiro, Contra Capa, 1998.

. O Inconsciente a Céu Aberto da Psicose. Rio de Janeiro, Zahar, 2007.

STANISLAVSKI, Constantin. A Criação de Um Papel. Rio de Janeiro: Civilização Brasileira, 2005.

Brasileira, 1970.

A Construção da Personagem. Rio de Janeiro: Civilização 
A Preparação do Ator. Rio de Janeiro: Civilização Brasileira, 1968.

1972.

A Preparação de Um Papel. Rio de Janeiro: Civilização Brasileira, . Minha Vida na Arte. Rio de Janeiro: Civilização Brasileira, 1989.

STANISLAVSKI, Konstantín. El trabajo del actor sobre si mismo em el proceso creador de la encarnación. Barcelona, Alba Editorial, 2009.

EI trabajo del actor sobre si mismo en el proceso creador de la vivencia. Barcelona, Alba Editorial, 2007.

STANISLAVSKIJ, Konstantin. Il lavoro dell'attore sul personaggio. Roma: Ed. Laterza, 1993.

StRASBERG, Lee. O Sonho de uma Paixão. Rio de Janeiro: Civilização Brasileira, 1990.

. Acting. New York: Crow, 1965.

SZONDI, Peter. Teoria do Drama Moderno. São Paulo: Cosac \& Naify, 2001.

TAKEDA, C. Layher. O Cotidiano de uma Lenda: Cartas do Teatro de Arte de Moscou. São Paulo: Perspectiva, 2003.

TARKOVSKI, Andrei. Esculpir o Tempo. São Paulo, Ed. Martins Fontes, 1998.

TEIXEIRA, Ubiratan. Dicionário de Teatro. São Luís, Instituto Geia, 2005.

TODOROV, Tristan. As Estruturas Narrativas. São Paulo: Perspectiva, 2003.

TOPORKOV, V. O. Las acciones Físicas como Metodologia. In: (org.) JIMENEZ, S. El Evangelio de Stanislavski Segun sus Apostoles. México: Gaceta, 1990.

TORRES, R. Dimensões do Ato em Psicanálise. São Paulo: Ed. Annablume, 2010.

UBERSFELD, Anne. Para Ler o Teatro. São Paulo: Perspectiva, 2005.

VANIER, Alain. Lacan. São Paulo: Estação Liberdade, 2005.

VASSÍLIEV, Anatoli. Sept ou Huit Leçons de Théâtre. Paris: P.O.L., 1999.

VIEIRA, M. A. A Paixão. Rio de Janeiro, Jorge Zahar Ed, 2012.

WISEMAN, B \& GROVES, J. Lévi-Strauss para Principiantes. Buenos Aires: Era Naciente, 1997.

WILlEMART, Philippe. Tratado das sensações em A Prisioneira de Marcel Proust. Curitiba: Opus Print Ed, 2008.

Além da Psicanálise: A Literatura e as Artes. São Paulo, Nova Alexandria, 1995.

WISNIK, José Miguel. O Som e o Sentido. São Paulo, Ed. Schwarcz, 2002.

WOODFIN, R \& GROVES, J. Aristóteles para Principiantes. Buenos Aires, Ea Naciente, 2002. 
XAVIER, Ismail. A Experiência do Cinema. Rio de Janeiro: Ed. Graal, 1991.

O Discurso Cinematográfico: A Opacidade e a Transparência. São Paulo, Ed. Paz e Terra, 2005.

ZUMTHOR, Paul. Performance, Recepção, Leitura. São Paulo: Cosac \& Naify, 2007.

7.2. Artigos publicados em jornais, revistas e anais:

ALCÂNTARA, Celina. O trabalho do ator e a arte de ficcionar a si mesmo. Revista Brasileira de Estudos da Presença. Porto Alegre, vol. 3, nº 3, p.902-922, 2013.

ALMEIDA, Joana Dória. Jan Fabre e a construção de um teatro híbrido. São Paulo, Revista Sala Preta, n. 7, p. 167-170, 2007.

ARRUDA, Rejane Kasting. Subpartitura e texto-dado: a troca para a inscrição do impulso. Anais da V Reunião Científica da ABRACE, São Paulo, ECA/USP, 2009.

Anteparo e impressão digital, a hipótese de um par fundamental. Anais do VI Congresso da ABRACE. São Paulo, ECA/USP, 2010.

A função do manuscrito nas artes cênicas: testemunho e reflexões de uma pesquisAtriz. Anais do X Congresso Internacional de Critica Genética, POA, 2010.

A hipótese de uma estrutura na diversidade dos jogos de criação atoral. Araraquara, Revista de Cultura Artística, ano 4, vol. 01, 2010.

. Anteparo e Impressão Digital: A Hipótese de um Par Fundamental. Anais do VI Congresso de Pesquisa e Pós-graduação em Artes Cênicas da ABRACE, 2010.

Jogo e escrita no trabalho com o texto dramático: relato de uma experiência em diálogo com a tradição. In: SILVA, Armando Sérgio (org). CEPECA: Uma oficina de pesquisAtores. São Paulo, Associação dos Amigos da Praça, 2010.

A pergunta que antecede à fala: um procedimento para o ator no cinema. Porto Alegre, Anais da VI Reunião Científica da ABRACE, 2011.

O Ateliê do Ator-encenador: Uma Possibilidade Pedagógica. São Paulo, Revista AspaS, n.1, 2011.

Uma reflexão sobre o indizível do corpo e suas articulações com a linguagem: por uma pedagogia da decomposição. Campinas, Revista Pitágoras 500: Estudos Teatrais da UNICAMP (abril/maio 2012)

A plasticidade corporal no jogo de enquadramentos de "A

Escolha”. Porto Alegre, Anais do VII Congresso da ABRACE, 2012. 
A Criação do Corpo em Articulação com a Estética Fílmica:

Modalidades de Agenciamento da Linguagem Cinematográfica pelo Ator,

Mexico, Anais II CUAC, 2012.

. Incidência e Enquadramento: Uma Possibilidade de Transmissão da

Prática Atoral. São Paulo, Revista aSPAs, vol.2, 2012, p.133-140.

. O Velho Kusnet. Lisboa, Atas do III Congresso Internacional Criadores Sobre Outras Obras, 2013, p. 584-587.

O Ator no Contexto da Direção Cinematográfica: Atuação como Território de Estranhamento. Coimbra, Atas do III Encontro Internacional da AIM, 2013 (a ser publicado).

Notas sobre a pesquisa em artes cênicas estrutura e singularidade Arte e Ciências em Diálogo. Algarve, Anais do Colóquio Internacional Arte e Ciências em Diálogo, p 260-264, 2013.

. Arte Atoral: Prática da Letra, Modalidade de Gozo. São Paulo, Anais da Jornada de Pesquisa do Instituto de Artes da UNESP, 2013.

A Incorporação do Pré-jogo Tentativas de Formalização de um Procedimento Estranho. Campinas, Revista Pitágoras 500: Estudos Teatrais da UNICAMP, 2013.

Deslocamento e Ruptura: O Espectador em Ato. Porto Alegre, Anais do 14o Simpósio da International Brecht Society, 2013, p 24-31.

Diversidade no Campo da Direção de Atores: Uma Estrutura da Prática da Atuação para a Orientação de Cineastas em Formação. Viana do Castelo, Atas da II Conferência Internacional de Cinema de Viana, 2013 (a ser publicado).

BAUMGÄRTEL, Stephan. A Peça história no âmbito das formas teatrais pósdramáticas. Florianópolis, Fênix - Revista de História e Estudos Culturais, Vol. 5, Ano V, no 4, 2008.

Teatro dramático e pós-dramático: conjunturas do século XXI. Itajaí, Revista de Teatro Porto Cênico, edição nº 1, p. 9-13, 2009.

BAUMGÄRTEL, S \& SILVA, Heloísa M. Possíveis processos da escrita teatral contemporânea Florianópolis, Revista Da Pesquisa, v. 3, n. 2, 2008.

BETTS, Jaime. Ato analítico, Ato religioso e Ato de Criação Artística. Revista da Associação Psicanalítica de Porto Alegre, n. 149, agosto de 2006.

BITENCOURT, Tuini. O Príncipe Constante de Ryszard Cieslak e Jerzy

Grotowski: Corpo-memória, Ato Real e Processo de Construção. Rio de Janeiro: Cadernos Virtuais de Pesquisa em Artes Cênicas, 2009. 
BOND, Fernanda. O Ator autor: a questão da autoria nas formas teatrais contemporâneas. Anais do VI Congresso de Pesquisa e Pós-graduação em Artes Cênicas, 2010.

BONDÍA, Jorge Larrosa. Notas sobre a experiência e o saber da experiência. Revista Brasileira de Educação, n.19, 2002, p. 20-28.

BURGARELli, C. G. Sujeito e Escrita. In: LEITE, N. V. A. Corpolinguagem: gestos e afetos. Campinas: Mercado das Letras, 2003.

CALDAS, Heloísa. Uma caligrafia cinematográfica: sobre escrita, corpo, cinema e psicanálise. In: LEITE, N. V. A. Linguagem e gozo. Campinas: Mercado das Letras, 2007.

CARLSON, Marvin. Some contemporary implications of the post-dramatic. Colóquio Pensar a Cena Contemporânea, UFSC, 2013 (não publicado).

CARREIRA, André. Teatro Contemporâneo: de Stanislavski a Bob Wilson. Itajaí, Revista de Teatro Porto Cênico, edição no 1, p. 6-8, 2009.

CERPA, Maritza Farías. Sentido de Composição na Atuação em Michael Chekhov. São Paulo, Revista aSPAs, vol.2, n.1, p.1120120, 2012.

COHEN, Renato. A cena transversa: confluências entre o teatro e a performance. Revista USP, N. 14, 1992.

CONSENTINO, Mariane Tezza. Relato de uma peculiar montagem de As Três Irmãs. São Paulo: PesquisAtor Revista do CEPECA, 2012.

CORREIA, T. Real, Simbólico e Imaginário em Lacan. Ciências Humanas em Revista. São Luis, v.3, número especial, junho de 2005.

COSTA, Iná Camargo. Aproximação e Distanciamento (O interesse de Brecht por Stanislavski). São Paulo, Revista Sala Preta, v.2, 2002

46, 2002.

CUKIERT, Michele. Considerações sobre o eu e o corpo em Lacan. Natal: UFRN, Estudos de Psicologia, v. 7, n. 1, 2002, p. 143-149.

DEL NERO, Luciana. Clarice Lispector e a Escrita do Sinthome. Psicanálise \& Barroco em Revista, v. 9, nº 2, p. 225-254, 2011.

DRAGO, Niuxa. O viés expressionista da cenografia de santa roa: entre escadas e efeitos luminosos. Rio de Janeiro, Revista O Percevejo, Vol. 4, № 1, 2012.

DUNKER, Christian. A Imagem entre o Olho e o Olhar In: Sobre Arte e Psicanálise. São Paulo: Escuta, 2006, v.1, p. 14-29

FABIÃO, Eleonora. Performance e teatro: poéticas e políticas da cena contemporânea. Sala Preta. Revista de Artes Cênicas. PPGAC/ECA/US, n.8, 2008, PP. 235-246. 
FARIA, João Roberto. A recepção de Zola e do Naturalismo nos palcos brasileiros.. Documentos (Série Estudos Brasil-França), IEA/USP, São Paulo, v. 4, p. 29-41, 1998. Disponível em: http://www.iea.usp.br/publicacoes/textos/fariazola.pdf Acesso em 08/01/2014.

FERAL, Josette. Performance e performatividade: o que são os Performance Studies?. In: Mostaço, Edelsio (org.) Sobre performatividade. Florianópolis: Letras Contemporâneas, 2009.

Por uma poética da performatividade: o teatro performativo. In:

Sala Preta, Revista do Programa de Pós-Graduação em Artes Cênicas, Eca/USP, São Paulo, n. 08, 2008, pg. 197-210.

Teatro Performativo e Pedagogia. São Paulo, Revista Sala Preta, n. 8, ECA/USP, 2008, p. 197-209.

FERNANDES, Silvia. Teatralidade e Performatividade na Cena Contemporânea. Salvador, Revista Repertório, N. 16, p. 11-23, 2011.

FERREIRA, Carolin. Uma breve história do teatro brasileiro moderno. Revista Nuestra América, No 5, p. 131-143, 2008.

FISCHER, Rodrigo. O corpo no cinema de John Cassavetes e sua importância para o trabalho do ator contemporâneo. São Paulo: PesquisAtor, Revista do CEPECA, N.1, 2012.

GROTOWSKI, Jerzy. Respuesta a Stanislavski. Máscara - Cuaderno Iberamericano de Reflexion sobre Esconologia (Grotowski), México, año 3, n. 11-12. p. 18-26, 1993.

GUENZBURGER, Gustavo. O pós-dramático é pós-moderno? Curitiba, Revista Científica da FAP, v.7, p. 141-152, 2011.

GULLAR, Ferreira. Entrevista. São Paulo, Revista Bravo, nº 158, p. 6-27, 2010

HASSAN, Sara Elena. Pintores e poetas no roteiro da pulsão escópica: anotações preliminares. São Paulo, Revista Caligrama, v. 4, n. 1, 2007.

IANNINI, Gilson. Figuras da verdade: a contingência e o impossível. Anais dos Estados Gerais da Psicanálise: Segundo Encontro Mundial, 2003.

LEHMANN, Hans-Thies. Teatro pós-dramático e processos de criação e aprendizagem da cena: um diálogo com Hans-Thies Lehamnn. São Paulo, Revista Sala Preta, v. 13, p. 236-251, 2013.

Wie politisch ist postdramatisches Theater? In: LEHMANN,

Hans-Thies. Das Politische Schreiben. Berlin: Theater der Zeit, 2002

(Recherchen 12), pp. 11 - 21, tradução de Stephan Baumgärtel (não publicada).

KHAN, François. Reflexões sobre a prática da memória no ofício do ator de teatro. Revista Sala Preta, ECA/USP, v. 9, 2009.

MACIEL, Andréa. A performance e seus diálogos com as vanguardas. $2^{\circ}$ Congresso Científico da UniverCidade, Rio de Janeiro, 2007. 
MACHADO, Bernardo. A Invenção da representação: breve reflexão sobre a noção de representação. Cadernos de Campo: Revista dos Alunos de Pós-graduação em Antropologia Social da USP, São Paulo, n.20, p.167-180, 2011.

MASAGÃO, Andrea. A Gramática do Corpo e a Escrita do Nome. São Paulo, Revista de Psicologia da USP, 2004.

. A rasura da letra e a explosão do semblante. Revista Ágora, vol. 11, $\mathrm{n}^{\circ} 2$, Rio de Janeiro, 2008.

. Criação. São Paulo, Revista Leitura Flutuante, v.1, 2009.

MATERnO, Ângela. O Olho e a Névoa: Considerações sobre a teoria do teatro. São Paulo, Revista Sala Preta, v. 3, 2003.

Isto não é um espetáculo: considerações sobre a dramaturgia contemporânea. Porto Alegre, Revista Folhetim, n²8, p. 52-60, 2009.

MEDEIROS, M. B. Corpos Informáticos: Performance, Corpo, Política. Brasília: Editora do PPG-Arte/UnB, 2011.

MEDEIROS, Francisco. Words In Process: texto teatral e leitura no teatro contemporâneo, entrevista com Francisco Medeiros. São Paulo, Revista Manuscrítica, n.22, p.116-136, 2012.

MERISIO, P. O melodrama francês: aspectos que se aproximam do melodrama circense-teatral no Brasil. Revista Ourirouver, n.5. Uberlândia: EDUFU, 2009.

MILARÉ, Sebastião. As estações poéticas de Antunes Filho. Revista USP, p. 39-42 1992. SESC SP, 2010.

Hierofania, O teatro segundo Antunes Filho. São Paulo, Edições

MOLA, Luis Guilherme. Interpretação e Poesia. Rio de Janeiro, Revista Stylus, $n^{\circ} 24$, 2012.

MONTAGNARI, Eduardo. Brecht: Estranhamento e Aprendizagem. Maringá:

Departamento de Letras Ed., Revista JIOP n.1, 2010 p. 9-17.

MONTEIRO, Gabriela. Corpo e espaço na obra de Peter Brook: Marat/Sade e os limites da representação. Rio de Janeiro, Revista O Percevejo, Vol. 2, $\mathrm{N}^{\mathrm{o}}$ 2, 2010 .

PIACENTINI, Ney Luiz. Eugênio Kusnet para os dias de hoje. São Paulo: PesquisAtor Revista do CEPECA, N.1, 2012.

PICON-VALLIN, Béatrice. Teatro híbrido, estilhaçado e múltiplo: um enfoque pedagógico. São Paulo, Revista Sala Preta, no 11, 2011.

A encenação e o texto. In: $\mathbf{A}$ arte do teatro: entre tradição e vanguarda: Meyerhold e a cena contemporânea. Rio de Janeiro: Teatro do pequeno gesto/Letra e imagem, 2006, p. 67-81. 
PUPO, Maria Lúcia. O Lúdico e a Construção do Sentido. Sala Preta. Departamento de Artes Cênicas, ECA-USP, junho de 2001, pp. 181-187.

RAMOS, Luiz Fernando. A Pedra de Toque. Humanidades (Brasília), v. 52, p. 27-34, 2006

A rubrica como literatura da teatralidade: modelos textuais $\&$ poéticas da cena. São Paulo, Revista Sala Preta, v.1, 2001.

RANGEL, Rodrigo. Pequeno panorama histórico do teatro polonês como base para uma herança artística ampla. Revista Científica da FAP, v.8, p. 155-131, 2011.

RIVERA, T. Cinema e Pulsão: Sobre "Irreversível", o Trauma e a Imagem. Revista do Departamento de Psicologia - UFF, v. 18 - n. 1 p. 71-76, Jan./Jun. 2006

SAMPAIO, Maria Everalda. Para Conhecer... Coordenador-Fundador do Centro de Pesquisa em Experimentação Cênica do Ator: Prof. Dr. Armando Sérgio da Silva. Belo Horizonte, Lamparina: Revista de Ensino de Teatro, v. 1, nº 02, 2001.

SANTOS, José Mario. Breve Histórico da "Performance Art" no Brasil e no Mundo. Salvador, Revista Ohun do Programa de Pós-graduação em Artes Visuais da Escola de Belas Artes da UFBA, nº 4, p.1-32, 2008.

SARRAZAC, Jean-Pierre. L'impersonnage. Études théâtrales 20. Paris/Louvain, Centre d' études théâtrales/Institut d' etudes théâtrales, 2001

A Oficina de Escrita Dramática. Educação e Realidade. Arte, Criação e Aprendizagem. Universidade Federal do Rio Grande do Sul, v.30, n. 2, jul./dez. 2005, pp. $203-215$.

1, p. 56-70, 2013.

SEIXAS, R. C. Uma discussão sobre o espaço cênico meyerholdiano. Anais da XVI Semana de Humanidades, GT 22. Programa de Pós-Graduação UFRN, 2008.

SILVA, Armando Sérgio. Os Estímulos para o Ator. São Paulo, Revista Sala Preta, v.2, 2010.

SILVA, Ipojucan Pereira. O "Performer Essencial" de Denise Stoklos fará sempre teatro (essencial)? São Paulo: PesquisAtor Revista do CEPECA, N.1, 2012.

SOLER, Collete. O "corpo falante". In: FINGERMANN, Dominique. (org.) Caderno de Stylus, n.1. Rio de Janeiro, Internacional dos Fóruns do Campo Lacaniano, 2010 .

STERNICK, Mara Viana. A imagem do corpo em Lacan. Revista Reverso, vol. 32, $\mathrm{n}^{\circ}$ 59, Belo Horizonte, 2010.

TOREZAN, Zeila Facci. Sublimação: da construção ao resgate do conceito. Rio de Janeiro, Ágora: Estudos em Teoria Psicanalítica, vol. 15, nº 2, 2012.

VILLAR, Fernando. La Fura dels Baus e performance arte: dramaturgias e ação. Ouro Preto, Revista Artefilosofia, p.186-197, 2009. 
WILLEMART, Philippe. Psicanálise e pedagogia ou Transmissão e formação. São Paulo, Revista USP, vol 31, p. 201-209, 1996.

\subsection{Dissertações e teses:}

ALMEIDA, Marcio Aurelio Pires de. O Encenador como Dramaturgo: A Escrita Poética do Espetáculo. Tese de Doutoramento, Universidade de São Paulo Escola de Comunicações e Artes, São Paulo, 1995.

ARRUDA, Rejane Kasting. Apropriação de texto: um jogo de imagens. Dissertação de Mestrado., Universidade de São Paulo, Escola de Comunicações e Artes, São Paulo, 2009.

CHNAIDERMAN, Miriam Schenkman. Corpo do Discurso e o Discurso do Corpo: Stanislavski e Freud. Tese de Doutoramento, Universidade de São Paulo Escola de Comunicações e Artes, São Paulo, 1994.

COELHO, Paula. A Experiência da Alteridade em Grotowski. Tese apresentada ao Programa de Pós-graduação em Artes Cênicas do Departamento de Artes Cênicas da ECA-USP. São Paulo, 2009.

CONSENTINO, Mariane Tezza. As Três Irmãs e a Subjetividade no Trabalho do Ator: Contribuições da Técnica de Clown. Dissertação de Mestrado - Escola de Comunicações e Artes, São Paulo, 2008.

DELDUQUE, Carolina. Rastros do Sistema de Stanislavski: Procedimentos para o Trabalho de Criação do Ator. Dissertação de Mestrado apresentada ao Instituto de Artes da UNICAMP, 2012.

DORNELlAS, José Raimundo. Caminhos da Formação do Ator: Conexões Interdiciplinares de Quatro Experiências. Dissertação de Mestrado - Escola de Comunicações e Artes, São Paulo, 2008.

JANUZELLI, Antonio Luiz Dias. O Ofício do Ator e o Estágio das Transparências. Tese de Doutoramento, Universidade de São Paulo - Escola de Comunicações e Artes, São Paulo, 1992.

LIMA, Tatiana Motta. Le Mots Pratiqués: relação entre terminologia e prática no percurso artístico de Jerzy Grotowski entre os anos de 1959 e 1974. Tese de Doutorado apresentada ao Programa de Pós-graduação em Teatro da UFRJ, 2008.

LOPES, Elisabeth Silva. A Linguagem Experimental do Teatro Brasileiro: Anos 80. Dissertação de Mestrado. Universidade de São Paulo - Escola de Comunicações e Artes, São Paulo, 1992.

MURCE FILHO, Newton. Corpoiesis: um ator, uma escrita. Tese apresentada ao Curso de Lingüística do Instituto de Estudos da Linguagem da UNICAMP, 2006.

PUPO, Maria Lúcia de S. B. Palavras em Jogo. Textos Literários e Teatro-Educação. Tese de Livre-Docência apresentada à ECA/USP, 1997. 
SILVA, Armando Sérgio. Interpretação: Uma Oficina da Essência. Tese de Livre Docência, Universidade de São Paulo - Escola de Comunicação e Artes, São Paulo, 1999.

A EAD do Dr. Alfredo: Uma Oficina de Atores. Tese de Doutoramento. Universidade de São Paulo - Escola de Comunicações e Artes, São Paulo, 1987.

SILVA, Antônio Araújo. A Encenação no Coletivo: Desterritorializações da Função do Diretor no Processo Colaborativo. Universidade de São Paulo - Escola de Comunicação e Artes, São Paulo, 2008.

A Gênese da Vertigem. Universidade de São Paulo - Escola de Comunicação e Artes, São Paulo, 2002.

SILVA, Andréia Elisete. Vakhtangov em Busca da Teatralidade. Dissertação apresentada ao Instituto de Artes da UNICAMP, 2008.

SILVEIRA, Juliana. Dramaturgia na Dança-teatro de Pina Bausch. Dissertação apresentada ao Programa de Pós-graduação da Escola de Belas Artes da UFMG, 2009.

TOREZAN, Zeila Facci. Sublimação, ato criativo e sujeito na psicanálise. Tese apresentada ao Programa de Pós-graduação em Psicologia no Centro de Filosofia e Ciências Humanas da UFSC, 2009.

ZANOTO, Sérgio Augusto. A cantora careca: um marco inicial no teatro do absurdo. Dissertação de mestrado. Assis: UNESP, 1987.

\subsection{Textos na Internet:}

AMARANTE, Dirce. Joyce e Beckett, Pés Diferentes no Mesmo Sapato. Revista Sibila: Poesia e Crítica Literária, 2009. http://sibila.com.br/critica/joyce-e-beckettpes-diferentes-num-mesmo-sapato/3019

ARTAUD, Antonin. Escritos de um Louco. Coletivo Sabotabem. Disponível em: http://unigalera1.geo.do/antonin.pdf Acesso em 14/01/2014.

AVILA, Norberto. Sobre o Teatro de Ionesco. Paris, s/d. Disponível em: http://www.yumpu.com/pt/document/view/13037077/n-quando-nicolas-batailleapresentava-a-uma-plateia-quase-a- Acesso em 08/01/2014.

CORREA, José Celso Martinez. O teatro está em todas as páginas. São Paulo:

Suplemento do Jornal O Estado de São Paulo, 01 de julho de 2011. Disponível em: http://www.estadao.com.br/noticias/suplementos,o-teatro-esta-em-todas-aspaginas, 739493,0.htm Acesso em 08/01/2014. 
GOMES, Renato. Vanguarda e Ilusionismo Teatral: Algumas Pistas. Rio de Janeiro, Matraga, Instituto de Letras da UERJ, p. 80-89. Disponível em: http://www.pgletras.uerj.br/matraga/matraga06_07/matraga6e7a10.pdf Acesso em 08/01/2014.

GROTOWSKI, Jerzy. Sobre o Método das Ações Físicas. Palestra no Festival de Teatro de Santo Arcangelo (Itália), jun 1988. Disponível em:

http://www.grupotempo.com.br/tex_grot.html Acesso em 06/01/2014.

KIFFER, Ana. Artaud, Momo ou Monstro? Centro de Estudos Claudio Ulpiano, 2010. Disponível em: http://claudioulpiano.org.br.s87743.gridserver.com/?p=258 (Acesso em 06/01/2014)

LAUTENSCHLAGER, Graziele. Bauhaus Imagem e espaço: Oskar Schlemmer e Moholy-Nagy. Programa de Pós-graduação em Arquitetura e Urbanismo da Escola de Engenharia de São Carlos da USP, São Carlos, 2007. Disponível em: http://www.nomads.usp.br/pesquisas/cultura_digital/arte_programmata/monografi as/Monografia_BauhausImagemEspaco.pdf. Acesso em 08/01/2014.

LIMA, Valéria. Vladimir Tatlin e o Construtivismo Russo. Blog Travessia Poética. Disponível em: http://valiteratura.blogspot.com.br/2011/12/vladimir-tatlin-e-oconstrutivismo.html. Acesso em: 08/01/2014.

Vestido de Noiva e o Teatro Contemporâneo Brasileiro de Nelson Rodrigues. Blog Travessia Poética. Disponível em: http://valiteratura.blogspot.com.br/2011/05/vestido-de-noiva-e-o-teatro.html. Acesso em 08/01/2013.

MAUCH, Michel \& CAMARGO, Robson. A "verdade" de Stanislavski e o ator criador: elos perdidos na tradução ao português da obra $A$ Construção $d a$ Personagem. Disponível em: https://www.academia.edu/193246/A_VERDADE_DE_STANISLAVSKI_E_O_A TOR_CRIADOR_ELOS_PERDIDOS_NA_TRADUCAO_AO_PORTUGUES_D A_OBRA_A_CONSTRUCAO_DA_PERSONAGEM._Michel_Mauch_e_Robson Correa_de_Camargo Acesso em 08/01/2014.

MENDONÇA, Antônio Sergio. Jacques Lacan, O Moderno e a Desconstrução. Rio Total Coojornal. Disponível em: http://www.riototal.com.br/coojornal/guardiaolacan005.htm Acesso em 08/01/2014.

MIGLIETTI, Francesca. Societas Raffaello Sanzio - Conversazione com Claudia e Romeo Castellucci. Undo Net Magazines. Disponível em: http://www.undo.net/it/magazines/933692074. Acesso em: 08/01/2014.

OLIVEIRA, Patrícia. Engène Ionesco ridicularizando a própria linguagem: uma leitura de A Cantora Careca. VI Seminário de Iniciação Científica, Só Letras, $2009 . \quad$ Disponível em: https://www.yumpu.com/pt/document/view/13037243/uma-leitura-de-a-cantoracareca-uenp Acesso em 08/01/2013. 
PICON-VAllin, B. A música no jogo do ator meyerholdiano. Disponível em: www.grupotempo.com.br Acesso em: 08/01/2014.

RAMOS, Graciliano. Linhas Tortas, 1962. Disponível no site oficial de Graciliano Ramos: http://graciliano.com.br/site/obra/linhas-tortas-1962/ Acesso 08/01/2014.

RAMOS, Luiz Fernando. La piedra do toque. Artea Investigación y Creación Estética. Disponível em: http://artesescenicas.uclm.es/archivos_subidos/textos/256/teatroposdramatico_lfram os.pdf Acesso em 08/01/2014

RIBEIRO, Valdelice. Catadores de Migalhas: um percurso entre a psicanálise e a arte. Disponível em: http://www.psicanalise.ufc.br/hot-site/pdf/Trabalhos/79.pdf Acesso em: 08/01/2014.

ROBERTO, Avila. Sobre o Teatro de Ionesco. Disponível em: http://www.yumpu.com/pt/document/view/13037077/n-quando-nicolas-batailleapresentava-a-uma-plateia-quase-a- Acesso em 08/01/2014

SALleS, Nara. As Correntes de Atuação Desenvolvidas no Período Pósrealismo/naturalismo. Disponível em: http://pt.scribd.com/doc/185738094/2Correntes-de-Atuacao-Desenvolvidas-No-Periodo-Pos-Realismo-Naturalismo1 Acesso em 08/01/2014.

Teatro Expressionista. Portal São Francisco: História do Teatro. Disponível em: http://www.portalsaofrancisco.com.br/alfa/historia-doteatro/teatro-expressionista-3.php Acesso em 16/01/2014.

TOLENTINO, Cristina. Várias fases do teatro de Tadeusz Kantor. Disponível em: http://www.caleidoscopio.art.br/cultural/teatro/teatro-contemporaneo/tadeuszkantor-fases.html Acesso em: 08/01/2014.

VILLAR, Fernando. O pós-dramático em cena: La Fura dels Baus. Disponível em http://webcache.googleusercontent.com/search?q=cache:k4SB3pyCsjUJ:www.geoc ities.ws/coma_arte/2005/anpap/fe_villar.doc $+\& c d=1 \& h \mathrm{~h}=\mathrm{pt}-\mathrm{BR} \& \mathrm{ct}=\mathrm{clnk} \& \mathrm{gl}=\mathrm{br}$ Acesso em 08/01/2014. 
VIII. ANEXO: OUTROS ATELIÊS (REGISTRO FOTOGRÁFICO)

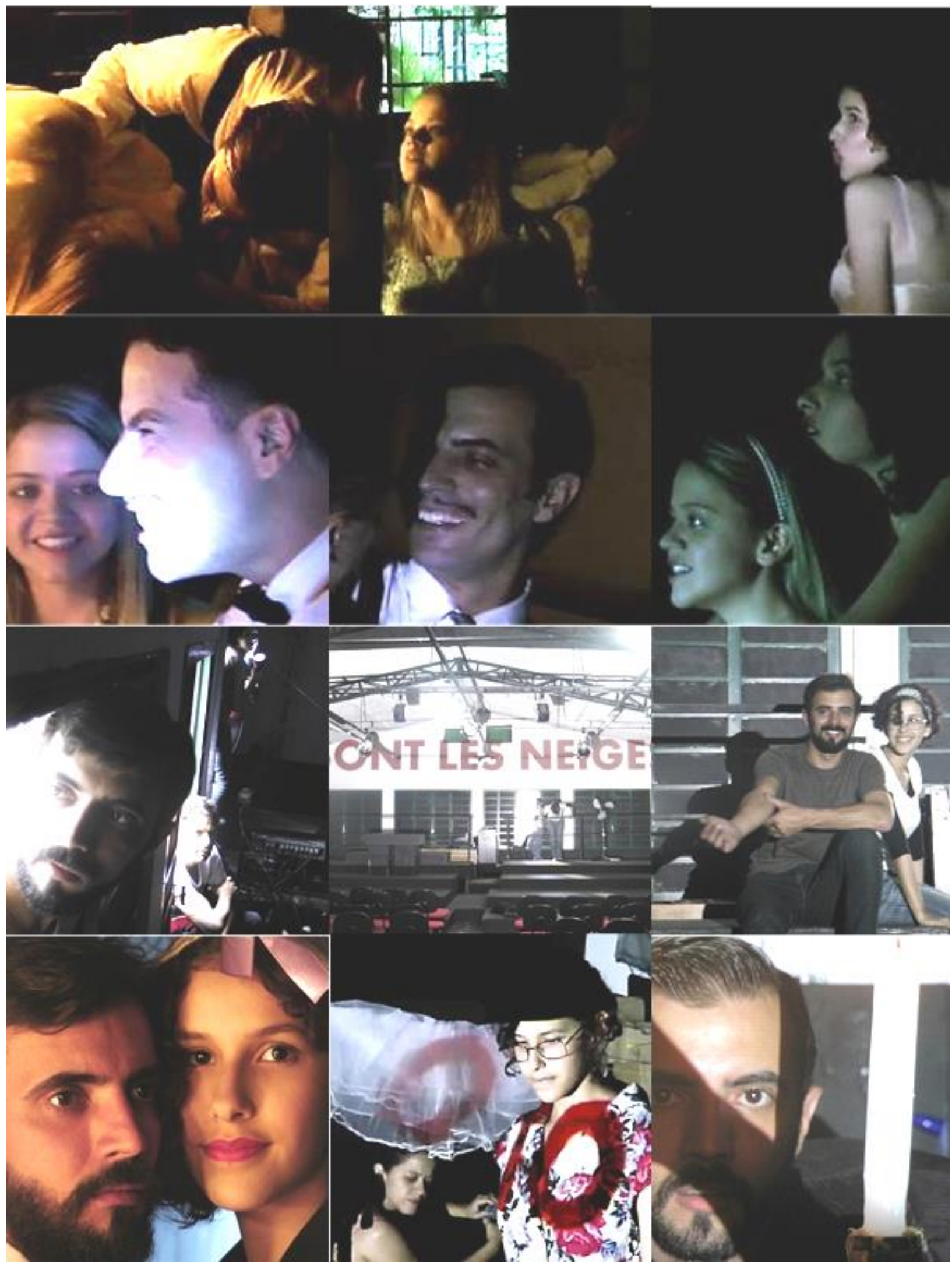

Figura 127: À Margem da Vida, de Tennessee Wiliiams Teatro Ireve Ravache, dezembro de 2013 


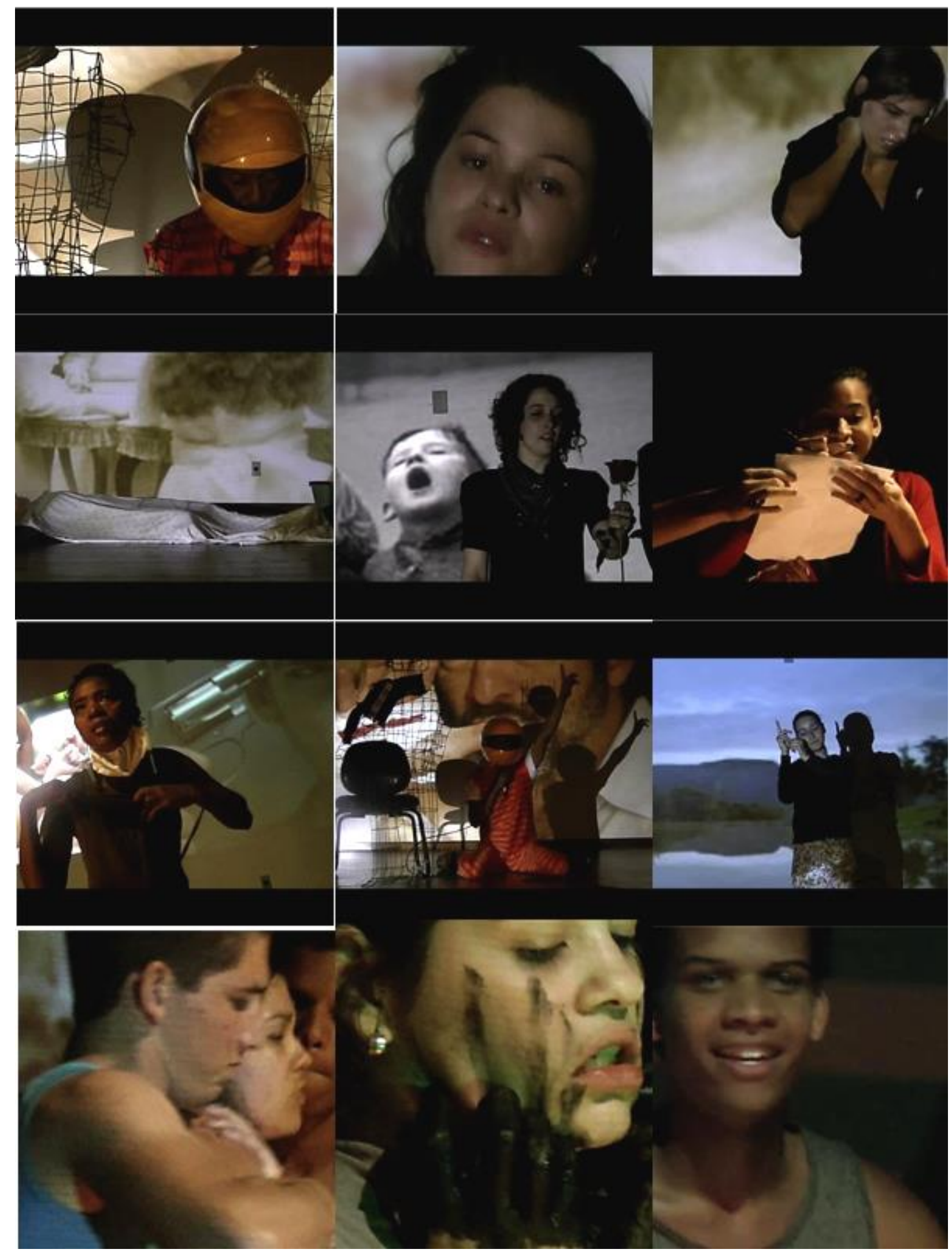

Figura 128: Grupo de Teatro da Universidade de Vila Velha (agosto a dezembro de 2013) 


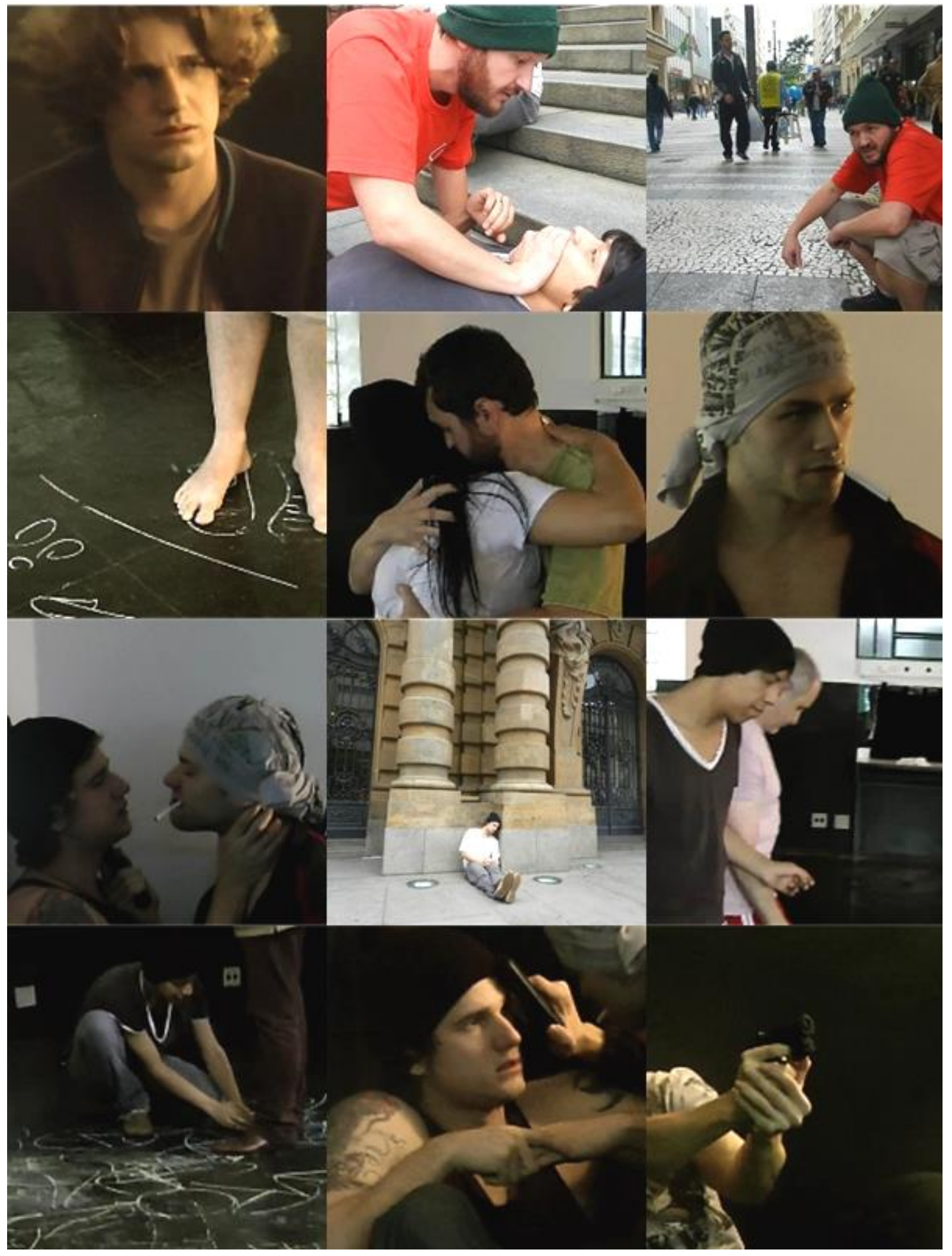

Figura 129: Work in progress de Dois Perdidos Numa Noite Suja (agosto a dezembro de 2013) 


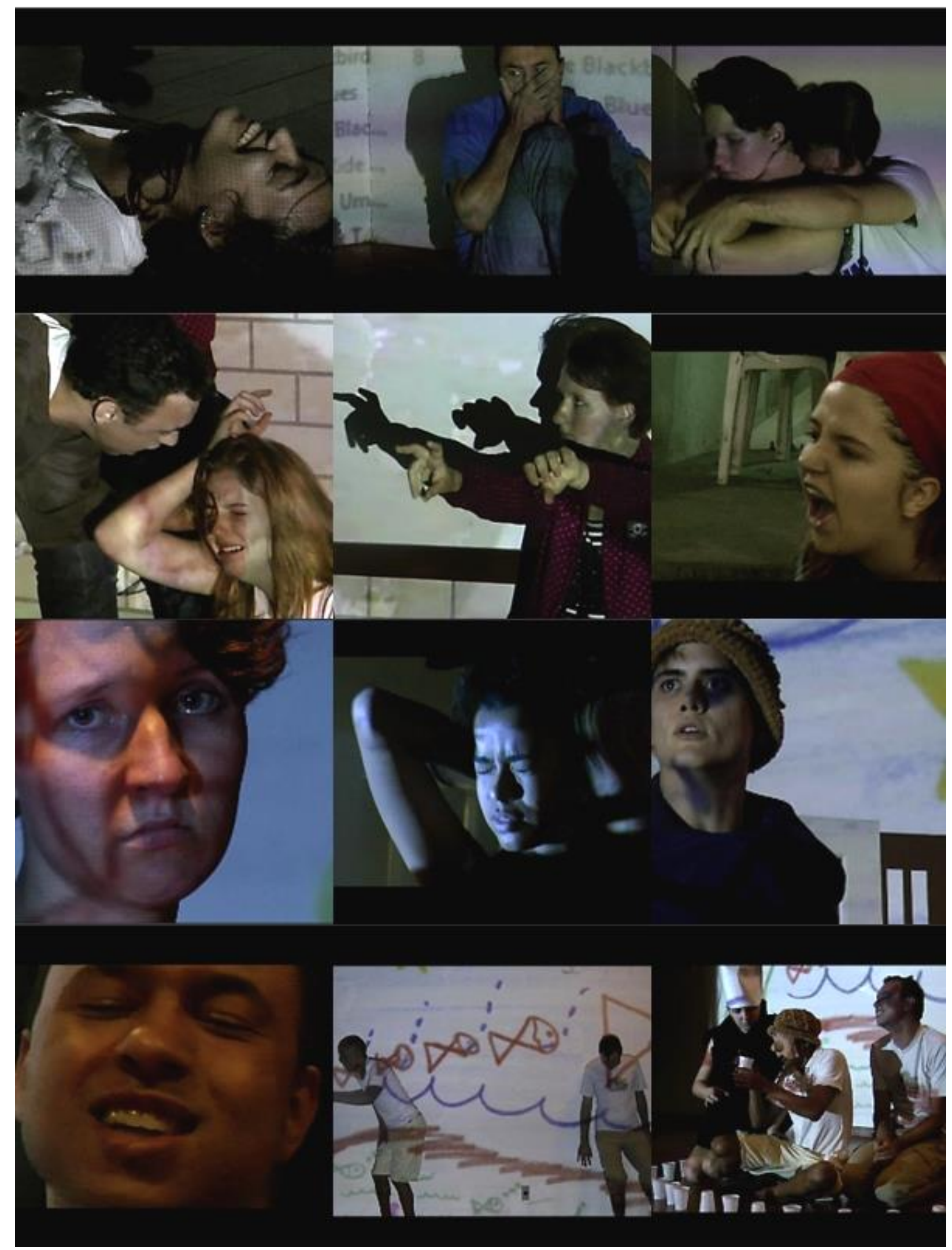

Figura 130: Interpretação Teatral I - Universidade de Vila Velha (ES) 


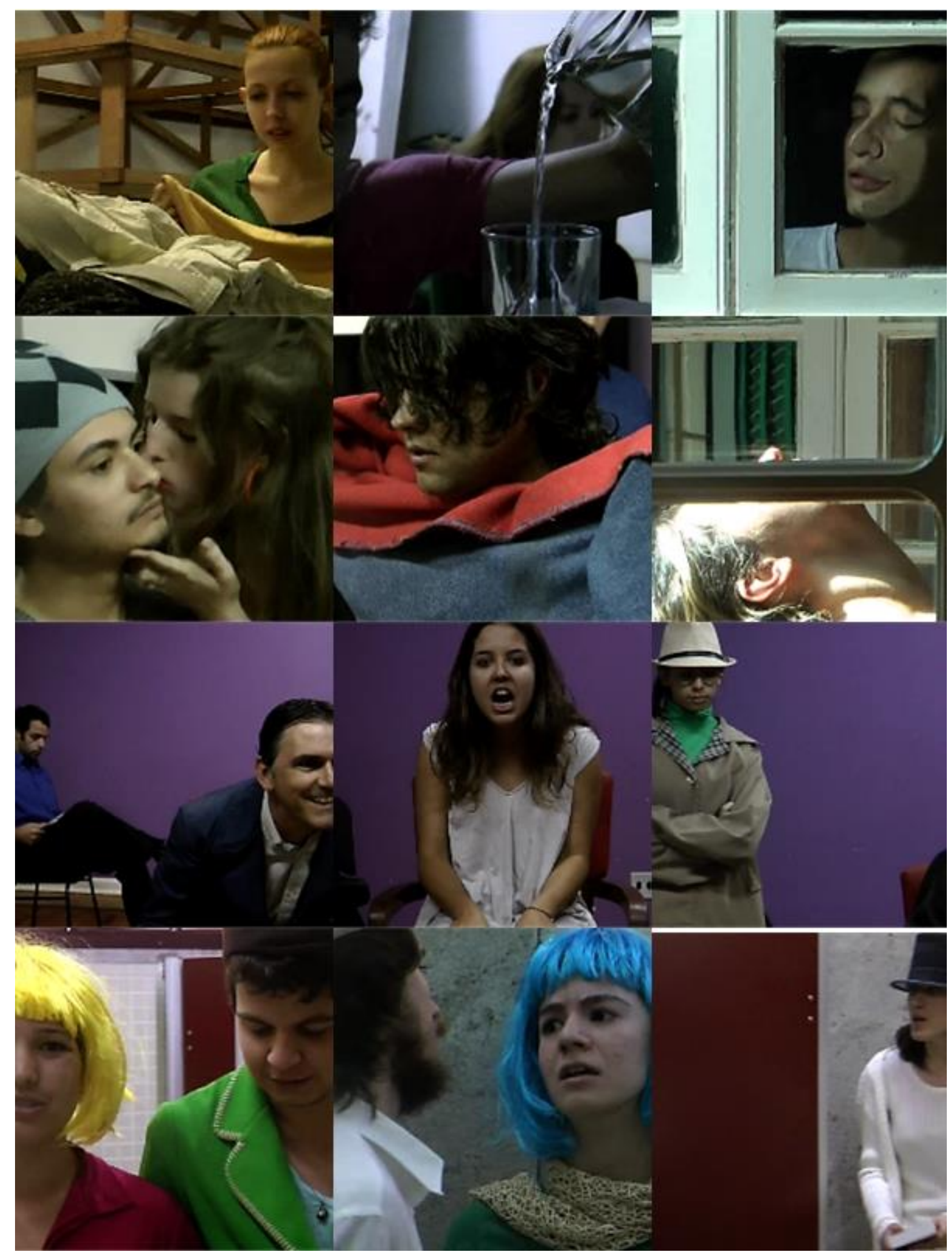

Figura 134: Workshops Circuito TUSP 2013 